\title{
EFEITOS DA ABERTURA COMERCIAL E DAS MUDANÇAS ESTRUTURAIS SOBRE O EMPREGO NA ECONOMIA BRASILEIRA: UMA ANÁLISE PARA A DÉCADA DE 1990
}

\author{
Cleise Maria de Almeida Tupich Hilgemberg
}

Tese apresentada à Escola Superior de Agricultura

"Luiz de Queiroz", Universidade de São Paulo, para obtenção do título de Doutor em Ciências, Área de Concentração: Economia Aplicada

P I R A C I C A B A

Estado de São Paulo - Brasil

Janeiro - 2003 


\title{
EFEITOS DA ABERTURA COMERCIAL E DAS MUDANÇAS ESTRUTURAIS SOBRE O EMPREGO NA ECONOMIA BRASILEIRA: UMA ANÁLISE PARA A DÉCADA DE 1990
}

\section{Cleise M aria de Almeida Tupich Hilgemberg}

Bacharel em Economia

Orientador: Prof. Dr. JOAQUIM JOSÉ MARTINS GUILHOTO

\author{
Tese apresentada à Escola Superior de Agricultura \\ "Luiz de Queiroz", Universidade de São Paulo, para \\ obtenção do título de Doutor em Ciências, Área de \\ Concentração: Economia Aplicada
}

P I R A C I C A B A

Estado de São Paulo - Brasil

Janeiro - 2003 
Dados Internacionais de Catalogação na Publicação (CIP) DIVISÃO DE BIBLIOTECA E DOCUMENTAÇÃO - ESALQ/USP

Hilgemberg, Cleise Maria de Almeida Tupich

Efeitos da abertura comerciale das mudanças estrutura is so bre o

emprego na economia brasileira: uma análise para a década de 1990 /

Cleise Maria de Almeida Tupich Hilgemberg. - - Piracicaba, 2003.

180 p. : il.

Tese (doutorado) - Escola Superior de Agricultura Luiz de Queiroz, 2003. Bibliografia.

1. Economia -Brasil 2. Economia do traba lho 3. G lobaliza ção 4. Insumo produto 5. Mão de obra 6. Mercado de trabalho I. Título

CDD 331

"Permitida a cópia total ou parcial deste documento, desde que citada a fonte - O autor" 
A meus pais, Estanislau (in memorian) e Cloris, e ao meu marido Emerson, amigo e grande amor da minha vida. 


\section{AGRADECIMENTOS}

Ao Prof. Joaquim Guilhoto, pela orientação competente e pela sabedoria em transmitir conhecimento, respeito e amizade.

Ao meu marido Emerson, pelo incansável apoio em todos os momentos do Curso e na realização desta Tese. Minha gratidão seria muito pequena, por isto doulhe minha vida e meu amor.

Ao meu pai (in memorian) e a minha mãe, por ter dedicado toda a sua vida à criação digna e responsável de seus filhos. Aos meus irmãos e cunhados pelo incentivo e convívio sempre alegres.

Aos meus irmãos adotivos: "Tio Chico", "Paulinho" e Marcos agradeço o carinho, a amizade, os bons e alguns difíceis momentos que dividimos durante este período e aos amigos do mestrado e doutorado, em especial ao Ferreira, Estevão, Márcia Istake, Paula, Izabel, Patrícia, Margarete e "Ricardinho", pelas lições de vida. Ao grupo Projeções Econômicas pelo agradável convívio e aprendizado.

Às professoras Márcia Azanha e Silvia Miranda e aos professores Rodolfo Hoffman e Alexandre Mendonça de Barros pelos úteis e preciosos comentários quando da apresentação do meu projeto de tese e nas etapas seguintes e aos funcionários do Departamento de Economia, Administração e Sociologia, em especial a Maielli, Luciane e Ligiana.

À Universidade Estadual de Ponta Grossa e CAPES, pelo apoio financeiro necessário para a realização deste trabalho e aos professores do departamento de Economia da UEPG, pelo apoio que possibilitou minha permanência em dedicação exclusiva durante este período. 


\section{SUMÁRIO}

Página

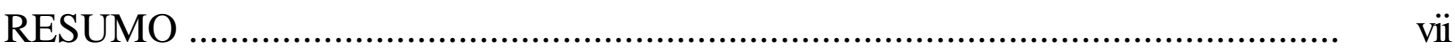

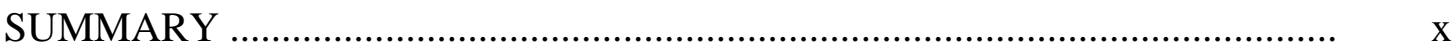

1 INTRODUÇÃO .......................................................................

$1.1 \quad$ Apresentação .................................................................................... 1

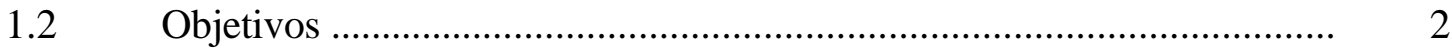

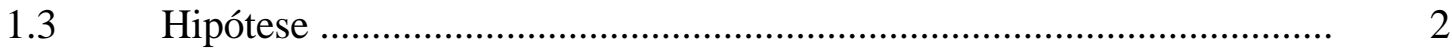

$1.4 \quad$ Organização do trabalho ...................................................................... 3

2 REVISÃO DE LITERATURA ............................................................ 4

3 EFEITOS DA ESTABILIZAÇÃO DO NÍVEL DE PREÇOS E DA ABERTURA ECONÔMICA SOBRE A OFERTA DE POSTOS DE TRABALHO NO BRASIL: UM ESTUDO PARA A DÉCADA DE $1990 \quad 16$

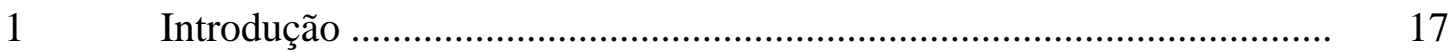

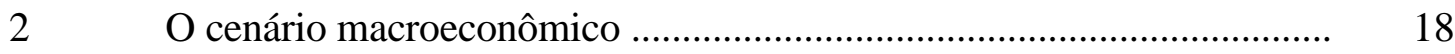

3 O mercado de trabalho: algumas considerações .................................... 20

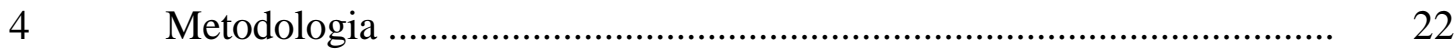

4.1 Modelo de insumo-produto ............................................................... 22

4.2 Análise da estrutura da economia ........................................................ 26

4.2.1 Multiplicadores de produção e de emprego ............................................. 26

4.2.2 Índice de turbulência ....................................................................... 29

4.2.3 Índices de ligação ............................................................................ 29

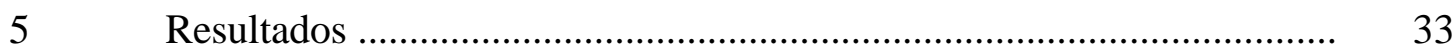

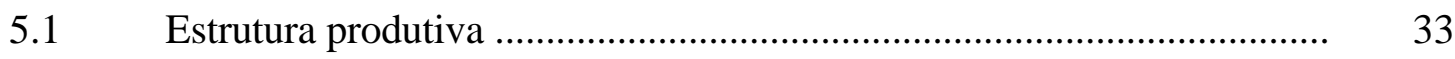

5.2 Efeitos da abertura comercial sobre o mercado de trabalho .................... 51 


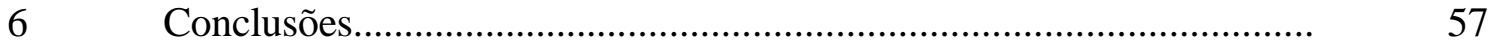

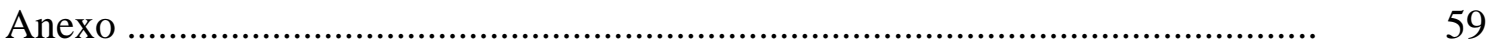

4 A ESTRUTURA SETORIAL DA OFERTA DE POSTOS DE TRABALHO NO BRASIL NA DÉCADA DE 1990 ..................................

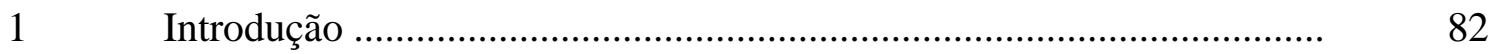

2 O mercado de trabalho brasileiro nos anos de 1990 ................................. 82

3 Insumo-produto aplicado ao mercado de trabalho ................................

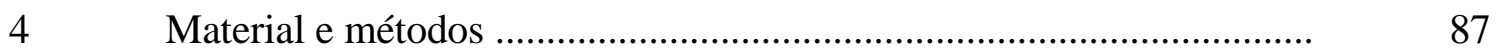

4.1 Dados da pesquisa .....................................................................

4.2 Compatibilização dos dados ................................................................

4.3 Modelo de insumo-produto ..............................................................

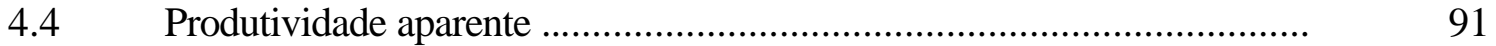

4.5 Análise de participação (shift share) ………………………………........

4.6 Índice de qualificação relativa …………………………………….......

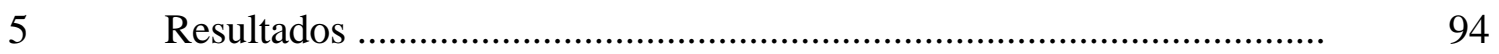

5.1 Características da mão-de-obra ocupada no Brasil ................................. 94

5.2 Panorama setorial da mão-de-obra ocupada no Brasil ............................ 100

5.3 Participação dos componentes da demanda total na oferta de postos de

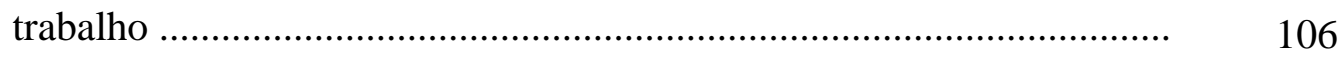

5.4 Perfil da mão-de-obra ocupada nos macro setores .................................. 109

5.4.1 Agropecuária ................................................................................. 110

5.4.2 Extrativa mineral (exceto combustíveis) ............................................... 112

5.4.3 Extração de petróleo, gás natural, carvão e outros combustíveis........... 113

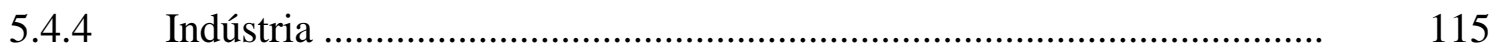

5.4.5 Serviços industriais de utilidade pública ................................................ 118

5.4.6 Construção civil ............................................................................. 119

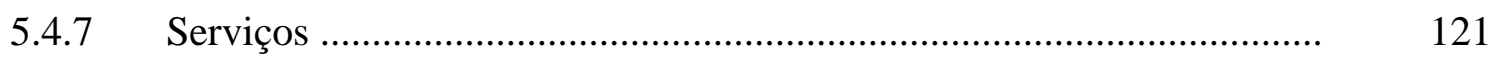

5.5 Índice de qualificação relativa da mão-de-obra ocupada ……………..... 123

$6 \quad$ Conclusões............................................................................... 125

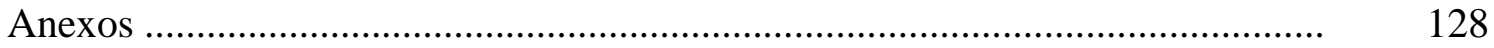

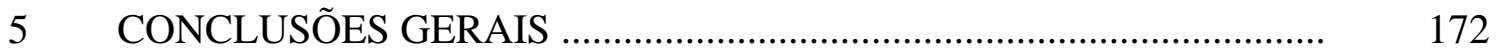

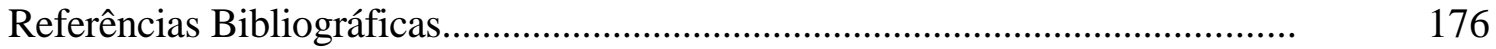




\title{
EFEITOS DA ABERTURA COMERCIAL E DAS MUDANÇAS ESTRUTURAIS SOBRE O EMPREGO NA ECONOMIA BRASILEIRA: UMA ANÁLISE PARA A DÉCADA DE 1990
}

\author{
Autora: CLEISE MARIA DE ALMEIDA TUPICH HILGEMBERG \\ Orientador: Prof. Dr. JOAQUIM JOSÉ MARTINS GUILHOTO
}

\section{RESUMO}

Este trabalho tem como objetivo geral investigar, sob a ótica de um modelo insumo-produto, os impactos no mercado setorial de trabalho no Brasil na década de 1990, evidenciando as transformações ocorridas no lado da oferta de postos de trabalho. Primeiramente, são analisados os efeitos do plano de estabilização do nível de preços e do processo de abertura econômica nos setores produtivos. Os resultados obtidos indicaram que o processo de abertura provocou efeitos positivos e negativos na estrutura produtiva. Setores como Agropecuária modernizaram seu processo de produção e aumentaram sua produtividade, diminuindo, porém, sua capacidade de geração de postos de trabalho. O setor Indústria apresentou-se dependente de insumos importados e também diminuiu sua capacidade de gerar empregos, entretanto o setor Serviços consolidou-se como grande gerador ou absorvedor de mão-de-obra neste período. Em geral, os multiplicadores de produção demonstraram que todos os setores passaram a ser mais dependentes de insumos importados. Neste período, a economia 
brasileira foi muito mais exportadora de produtos intensivos em trabalho e grande importadora de produtos intensivos em capital, implicando em mudanças na estrutura da oferta de postos de trabalho. Em geral, os multiplicadores de emprego mostraram uma queda na capacidade de geração de novos postos de trabalho (empregos diretos, indiretos e induzidos) em toda a economia. Em seguida, analisou-se a estrutura da oferta de postos de trabalho no Brasil na década de 1990. A análise do perfil da mão-de-obra ocupada mostrou que somente algo em torno de $1 / 3$ dos postos de trabalho foram ocupados pela mão-de-obra feminina, a qual estava concentrada no setor Serviços. Para o conjunto da economia, a idade do trabalhador ocupado concentrou-se na faixa dos 20 a 39 anos, tendo diminuído a participação da mão-de-obra jovem e aumentado, ainda que timidamente, a ocupação de trabalhadores com idade superior a 50 anos. $O$ setor Agropecuária foi o que mais empregou mão-de-obra na faixa dos 10 a 14 anos. Em contrapartida, no setor Extração de petróleo, gás natural, carvão e outros combustíveis, os postos de trabalho ocupados nesta categoria são desprezíveis. Este setor é o que ocupa com mais intensidade a mão-de-obra madura (acima dos 40 anos). A maioria da mão-deobra ocupada na década começou a trabalhar com 10 a 14 anos, porém os trabalhadores que estão ingressando atualmente no primeiro emprego, o fazem mais tarde. A análise da situação na ocupação dos trabalhadores mostrou que, notadamente a partir da segunda metade da década, houve um crescimento do número de trabalhadores sem carteira assinada, indicando uma possível piora nas relações de trabalho. Constatou-se ainda uma redução abrupta no número de pessoas trabalhando por conta própria e um aumento no número de postos de trabalho na administração pública. Não obstante, os trabalhadores ocupados no setor Extração de petróleo, gás natural, carvão e outros combustíveis e no setor Serviços industriais de utilidade pública eram, em sua grande maioria, contratados com carteira de trabalho assinada. O tempo de serviço da mão-de-obra ocupada na década de 1990 parece também indicar a precarização das relações de trabalho. Ao longo da década, algo em torno de $40 \%$ das pessoas estavam no atual emprego entre menos de 1 ano a 2 anos. A rotatividade é maior no setor Construção civil, onde, em média, 53\% dos trabalhadores estavam no atual emprego a menos de 2 anos. Na década de 1990, o número de horas de trabalho semanais era maior que 45 horas para cerca de 
$40 \%$ da mão-de-obra ocupada, embora mais de 20\%, em média, dos trabalhadores ocupados trabalhava em tempo parcial. No setor Serviços esta jornada de trabalho era mais comum. Em que pese ter-se observado, a partir da segunda metade da década de 1990, um ligeiro crescimento para a escolaridade da mão-de-obra ocupada entre 8 a 14 anos, a maioria dos trabalhadores ocupados durante todo período analisado possui de 4 a 7 anos de estudo. Não obstante, a construção de um índice de qualificação relativa permitiu verificar a intensidade do emprego de trabalhadores nos vários níveis de qualificação. Os resultados também mostraram que, na década de 1990, o consumo intermediário foi responsável, em média, por mais da metade da oferta de postos de trabalho. Dos trinta e um setores analisados, dezoito dependem mais fortemente do consumo intermediário. A demanda final foi significativa em onze setores e apenas em um [Extrativa mineral (exceto combustíveis)] a exportação teve a maior participação na oferta de postos de trabalho. 


\title{
COMMERCIAL OPENNESS AND STRUCTURAL CHANGE EFFECTS ON BRAZILIAN ECONOMY EMPLOYMENT: AN ANALYSIS FOR THE DECADE OF 1990
}

\author{
Author : CLEISE MARIA DE ALMEIDA TUPICH HILGEMBERG \\ Adviser: Prof. Dr. JOAQUIM JOSÉ MARTINS GUILHOTO
}

\section{SUMMARY}

This work has as general objective to investigate, through an input-output model, the impacts in the sectorial labor market in Brazil in the decade of 1990, evidencing the transformations happened on the side of the supply of work positions. Firstly, the effects of the price level stabilization plan and of the process of economical opening on the productive sectors are analyzed. The results indicated that the opening process has caused positive and negative effects in the productive structure. Sectors as the agricultural modernized its production process and increased his productivity, decreasing, however, its capacity of work positions generation. The Industry sector came dependent of imported inputs and it also reduced its capacity to generate jobs, however the Services sector consolidated as great generator and/or absorbing of labor in this period. In general, the production multipliers demonstrated that all of the sectors became more dependents of imported inputs. In this period, the Brazilian economy was very more a work intensive products exporter and a great capital-intensive products importing, leading to changes in the structure of the work positions supply. In general, 
the employment multipliers showed a decrease in the ability to generate new work positions (direct, indirect and induced) in all the economy. Afterwards, the structure of the Brazilian work positions supply in the last nineties was analyzed. The occupied worker profile analysis showed that only about $1 / 3$ of the work positions was filled for women, which was concentrated in the Services sector. For all the economy, the occupied worker's age concentrated on the 20 - 39 range. The participation of the young labor was reduced and the occupation of workers with 50 years old or more has a little increase. The agricultural sector used the major proportion of 10 to 14 years old workers. Otherwise, in the Petroleum and gas mining sector, the use of this category of workers is despicable. This sector is the major user of the mature labor force (above the 40 years). In the decade, most of the occupied workers began to work with 10 to 14 years, however the workers that are entering now in their first job, are doing it later. The analysis of the situation in the occupation showed that, especially starting from the second half of the decade, there was a growth of the number of workers in the informal sector, indicating a possible worsening in the work relationships. It was still verified an abrupt reduction in the number of people working independently and an increase in the number of work positions in the Public administration. In spite of, the occupied workers in the Petroleum and gas mining sector and in the Public utilities sector have a formal work relationship. The time in the current job seems also to indicate some worsening of the work relationship. Along the decade, something around $40 \%$ of the people was in the current job among less than 1 year to 2 years. The rotation is larger in the Construction sector, where, on average, $53 \%$ of the workers were less than 2 years in the current job. In the decade of 1990, the number of weekly working hours was larger than 45 hours for about $40 \%$ of the occupied workers, although more than $20 \%$, on average, was working in partial time. In the Services sector the partial timework was more common. Starting from the second half of the decade of 1990, a quick growth in the category of occupied labor between 8 to 14 education years was observed. However, most of the occupied workers during analyzed period have from 4 to 7 years of study. In this sense, the construction of an index of relative qualification allowed to verify the intensity of the work occupation in the several qualification levels. The results also showed that, in the 
decade of 1990, the intermediate consumption was responsible, on average, for more of the half of the work positions supply. Of the 31 analyzed sectors, eighteen depend more strongly on the intermediate consumption. The final demand was significant in eleven sections and just in a sector (Metal mining) the export had the largest participation in the work positions supply. 


\section{INTRODUÇÃO}

\subsection{Apresentação}

Este trabalho tem por objetivo analisar os impactos no mercado de trabalho da economia brasileira na década de 1990, surgidos como consequiência da reestruturação produtiva e das reformas econômicas implementadas neste período.

No final do século XX observou-se uma mudança setorial na composição relativa da população ocupada. Enquanto, no setor terciário, aumentaram os postos de trabalho, houve uma diminuição destes nos setores primário e secundário (Pochmann,1999). Uma vez que o setor terciário não foi capaz de absorver a mão-deobra dispensada pelos demais setores, persistiram elevadas taxas de desemprego, as quais levaram a uma deterioração das relações de trabalho.

No caso brasileiro, o esgotamento do modelo de substituição de importações deu lugar a um processo de abertura da economia, provocando mudanças na forma de produzir que também impactaram negativamente o mercado de trabalho.

Este processo, reforçado pela política macroeconômica de estabilização do nível de preços do Plano Real, que, por intermédio da valorização cambial, expôs a economia nacional à concorrência internacional, fez com que postos de trabalho fossem eliminados.

Este processo foi agravado pela falta de flexibilidade e de qualificação da mão-de-obra, que impediam uma grande parcela da força de trabalho de exercer tarefas mais sofisticadas (Kon, 1998). 
Esta pesquisa procura dispensar maior atenção a esta dinâmica do mercado de trabalho, em particular aos reflexos das alterações nas relações de produção, trabalho e emprego.

Para tanto, identifica em que setores encontram-se os maiores graus de transformação decorrentes da abertura comercial e da política de estabilização e caracteriza a dinâmica da estrutura da oferta de postos de trabalho na economia brasileira nos anos 1990.

\subsection{Objetivos}

O objetivo geral deste trabalho é investigar, sob a ótica de um modelo insumo-produto, os impactos no mercado setorial de trabalho no Brasil na década de 1990.

Tais transformações referem-se basicamente as modificações do lado da oferta de postos de trabalho neste período.

Esta motivação básica traduz-se numa série de objetivos específicos:

1. Analisar o processo recente de transformação produtiva e no emprego para os setores econômicos em relação ao processo de abertura econômica implementado no período;

2. Analisar a influência na oferta de emprego de variáveis relacionadas não só a qualificação da mão-de-obra, mas também com o perfil do trabalhador (sexo, idade, tempo de serviço, idade de ingresso no mercado de trabalho e jornada de trabalho, situação ocupacional);

3. Verificar a importância de cada um dos componentes da demanda interindustrial e final na oferta setorial de emprego.

\subsection{Hipótese}

A hipótese que norteia o presente trabalho é a de que o Brasil seguiu a tendência de terciarização verificada em outros países industrializados nos anos noventa, ou seja da migração de postos de trabalho para o setor serviços. 


\subsection{Organização do trabalho}

Esta pesquisa foi organizada em forma de artigos científicos. Assim sendo, a seção seguinte apresenta uma breve revisão da literatura sobre o comportamento do mercado de trabalho na década de 1990.

O primeiro capítulo verifica os efeitos da abertura econômica na estrutura produtiva e na oferta de postos de trabalho na economia brasileira e o segundo analisa a estrutura setorial do mercado de trabalho, evidenciando a qualificação da mão-de-obra e a importância de cada um dos componentes da demanda interindustrial e final na oferta setorial de emprego no Brasil. O último capítulo apresenta as considerações finais. 


\section{REVISÃO DE LITERATURA}

Ao longo das últimas décadas, as economias ocidentais têm experimentado transformações que acabaram por resultar não só na diminuição de postos de trabalho, mas também no potencial de geração de novos empregos. No nível setorial, a diminuição progressiva do peso das atividades agrícolas e industriais em todo o mundo vem proporcionando um aumento na importância relativa do setor serviços no mercado de trabalho (Cuadrado-Roura, 1999; OECD, 2002; CEPAL, 2001).

Cuadrado-Roura (1999) mostrou que a diminuição do emprego na agricultura e na indústria em países da União Européia caminha em paralelo com o aumento do número de empregos no setor de serviços (tabela 1).

Tabela 1. Participação percentual relativa dos setores no total do emprego na União Européia.

\begin{tabular}{lrrrrrrr}
\hline Setor & 1990 & 1991 & 1994 & 1996 & 1997 & 1998 & 1999 \\
\hline Agricultura & 6.7 & 6.3 & 5.5 & 5.1 & 5.0 & 4.7 & 4.4 \\
Indústria & 33.3 & 33.3 & 30.7 & 29.9 & 29.6 & 29.6 & 29.3 \\
Serviços & 60.1 & 60.3 & 63.7 & 65.0 & 65.4 & 65.7 & 66.3 \\
\hline
\end{tabular}

Fonte: Organization for Economic Cooperation and Development - OECD (2002)

Os principais indicadores do mercado de trabalho na União Européia mostram que, na década de 1990, aproximadamente a metade da força de trabalho era composta por mulheres com idades entre 15 e 64 anos. O setor serviços, que apresentou 
um contínuo crescimento durante o período, foi quem absorveu grande parte desta mãode-obra (tabela 2).

Tabela 2. Participação feminina no mercado setorial de trabalho na União Européia.

\begin{tabular}{lrrrrrrr}
\hline & 1990 & 1991 & 1994 & 1996 & 1997 & 1998 & 1999 \\
\hline PEA (15 a 64 anos) $^{1}$ & 229.683 & 242.023 & 244.180 & 245.927 & 246.284 & 246.826 & 247.296 \\
Mulheres entre 15 e 64 anos $^{1}$ & 115.634 & 121.741 & 122.398 & 123.258 & 123.387 & 123.541 & 123.818 \\
Participação no total (\%) & 50,34 & 50,30 & 50,13 & 50,12 & 50,01 & 50,05 & 50,07 \\
Agricultura & 5,9 & 5,6 & 4,6 & 4,2 & 4,0 & 3,7 & 3,5 \\
Indústria & 19,8 & 20,0 & 17,3 & 16,4 & 16,0 & 16,0 & 15,6 \\
Serviços & 74,2 & 74,5 & 78,1 & 79,4 & 80,0 & 80,3 & 80,9 \\
\hline
\end{tabular}

Fonte: OECD (2002)

${ }^{1}$ Expressos em mil pessoas

Embora a participação dos homens seja maior no setor secundário, observa-se o mesmo fenômeno de aumento relativo de postos de trabalho no setor serviços (tabela 3).

Tabela 3. Participação masculina no mercado setorial de trabalho na União Européia.

\begin{tabular}{lrrrrrrr}
\hline & 1990 & 1991 & 1994 & 1996 & 1997 & 1998 & 1999 \\
\hline PEA (15 a 64 anos) $^{1}$ & 229.683 & 242.023 & 244.180 & 245.927 & 246.284 & 246.826 & 247.296 \\
Homens entre 15 e 64 anos $^{1}$ & 114.049 & 120.282 & 121.781 & 122.679 & 122.896 & 123.282 & 123.478 \\
Participação no total (\%) & 49,65 & 49,69 & 49,87 & 49,88 & 49,90 & 49,94 & 49,93 \\
Agricultura & 7,1 & 6,9 & 6,1 & 5,7 & 5,7 & 5,4 & 5,1 \\
Indústria & 42,1 & 42,5 & 40,1 & 39,6 & 39,4 & 39,5 & 39,3 \\
Serviços & 50,7 & 50,7 & 53,7 & 54,7 & 55,0 & 55,1 & 55,6 \\
\hline
\end{tabular}

Fonte: OECD (2002)

${ }^{1}$ Expressos em mil pessoas 
Não obstante, a taxa de desemprego da população economicamente ativa (PEA) aumentou neste período, passando de 7,7 \% em 1990 para 9,2 \% em 1999 (figura 1).

Tomando-se por base as taxas apresentadas em OCDE (2002), o desemprego é maior entre as mulheres (entre elas o desemprego saltou de 9,8\% no início da década para 10,9 \% em 1999) e jovens de 15 a 24 anos (8,2\% em 1990, passando para 8,4 \% em 1999). O desemprego entre os homens foi menor em relação a média (passou de 6,2\% em 1990 para 7,9\% em 1999), entretanto, foram eles que sofreram com a diminuição nos postos de trabalho (figura 1).

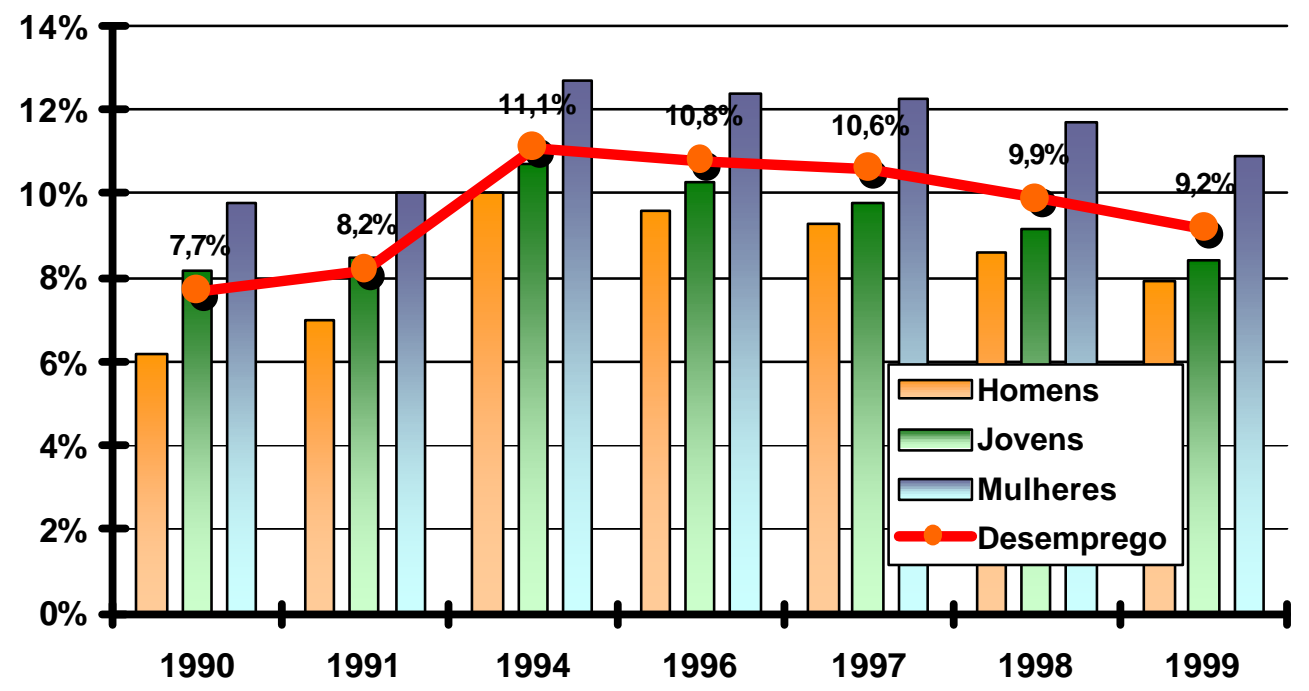

Figura 1 - Taxa de desemprego na União Européia nos anos 90.

O aumento na importância relativa do setor serviços também pode ser observado nos EUA e Japão. No primeiro, mais de $2 / 3$ dos postos de trabalho situam-se no setor terciário, no segundo, quase $60 \%$ deles (tabela 4). 
Tabela 4. Distribuição percentual dos empregos por setor econômico nos EUA e Japão na década de 1990.

\begin{tabular}{|c|c|c|c|}
\hline País & Agropecuária & Indústria & Serviços \\
\hline EUA & 3,5 & 24,7 & 71,8 \\
\hline Japão & 7,2 & 33,7 & 59,1 \\
\hline
\end{tabular}

Fonte: Marques (1998)

Quanto ao desemprego, estes dois países apresentaram um comportamento diverso ao longo da década. Os EUA experimentaram uma elevação da taxa de desemprego no início da década seguida de uma recuperação que foi capaz de fazer com que o desemprego em 1999 fosse o menor do período analisado. O caso japonês apresentou um comportamento oposto ao caso americano, isto é, no início do período as taxas de desemprego eram relativamente baixas e, após 1993, cresceram até alcançar, em 1999, o maior nível da década (tabela 5).

Tabela 5. Taxa de desemprego (\% da força de trabalho) nos EUA e Japão .

\begin{tabular}{lcccccccccc}
\hline País & 1990 & 1991 & 1992 & 1993 & 1994 & 1995 & 1996 & 1997 & 1998 & 1999 \\
\hline EUA & 5,6 & 6,8 & 7,5 & 6,9 & 6,1 & 5,6 & 5,4 & 4,9 & 4,5 & 4,2 \\
Japão & 2,1 & 2,1 & 2,2 & 2,5 & 2,9 & 3,1 & 3,4 & 3,4 & 4,1 & 4,7 \\
\hline
\end{tabular}

Fonte: OECD (2002)

No caso dos países da América do Norte, comparando-se o início e o fim da década, nota-se que o Canadá vem apresentando uma queda na relação emprego/população entre 15 a 24 anos, o que indica diminuição na participação de homens e mulheres na força de trabalho. Não obstante, a taxa de desemprego aumentou nesta faixa etária, atingindo com mais intensidade os homens. Na faixa etária de 25 a 54 anos observou-se um pequeno aumento na relação emprego/população no caso das mulheres. A taxa de desemprego nesta faixa etária diminuiu para ambos os sexos, 
embora com menos intensidade para os homens. Na faixa etária de 55 a 64 anos diminuiu a relação emprego/população entre os homens e aumentou entre as mulheres. Ao mesmo tempo, a taxa de desemprego masculino praticamente não se alterou, ao passo que a feminina apresentou uma pequena queda (tabela 6).

Nos EUA a elação emprego/população entre 15 a 24 anos diminuiu no caso dos homens e aumentou no caso das mulheres, ao passo que a taxa de desemprego apresentou uma pequena queda para ambos os sexos. Entre 25 e 54 anos, a relação emprego/população apresentou um aumento no caso das mulheres. No entanto, as taxas de desemprego diminuem com mais intensidade no caso dos homens. Na faixa entre 55 e 64 anos, observou-se um aumento acentuado no caso das mulheres e menor no caso dos homens. As taxas de desemprego para esta faixa diminuíram mais no caso dos homens (tabela 6).

Para o México, a relação emprego população para os jovens de 15 a 24 anos praticamente não se alterou no caso dos homens e tem um pequeno aumento no caso das mulheres, ao mesmo tempo em que o desemprego masculino aumentou e o feminino diminuiu. No caso da faixa entre 25 a 54 anos, observou-se uma pequena queda na relação emprego/população masculina e um aumento acentuado no caso das mulheres. A taxa de desemprego masculina praticamente não se alterou e a feminina caiu. Na faixa entre 55 a 64 anos, houve uma queda na relação emprego/população no caso dos homens e um aumento no caso das mulheres. A taxa de desemprego é baixa em ambos os casos durante toda a década (tabela 6). 
Tabela 6. Taxas de emprego/população ${ }^{1}$ e de desemprego ${ }^{2}$ por idade e gênero na América do Norte.

\begin{tabular}{|c|c|c|c|c|c|c|c|c|c|c|c|c|}
\hline & \multicolumn{4}{|c|}{15 a 24 anos } & \multicolumn{4}{|c|}{25 a 54 anos } & \multicolumn{4}{|c|}{55 a 64 anos } \\
\hline & \multicolumn{2}{|c|}{1990} & \multicolumn{2}{|c|}{1999} & \multicolumn{2}{|c|}{1990} & \multicolumn{2}{|c|}{1999} & \multicolumn{2}{|c|}{1990} & \multicolumn{2}{|c|}{1999} \\
\hline & Masc. & Fem. & Masc. & Fem. & Masc. & Fem. & Masc. & Fem. & Masc. & Fem. & Masc. & Fem. \\
\hline \multicolumn{13}{|l|}{ Canadá } \\
\hline Desemprego & 13,6 & 11,0 & 15,3 & 12,6 & 7,2 & 7,6 & 6,5 & 6,3 & 6,2 & 5,7 & 6,3 & 5,3 \\
\hline Emprego/população & 62,3 & 59,9 & 55,4 & 53,9 & 86,4 & 69,7 & 85,1 & 73,2 & 60,3 & 33,0 & 56,9 & 37,3 \\
\hline \multicolumn{13}{|l|}{ Estados Unidos } \\
\hline Desemprego & 11,6 & 10,7 & 10,3 & 9,5 & 4,6 & 4,6 & 3,0 & 3,4 & 3,8 & 2,8 & 2,7 & 2,6 \\
\hline Emprego/população & 63,5 & 56,10 & 61,0 & 57,0 & 89,1 & 70,6 & 89,0 & 74,1 & 65,2 & 44,0 & 66,1 & 50,1 \\
\hline \multicolumn{13}{|l|}{ México } \\
\hline Desemprego & 5,2 & 5,8 & 7,7 & 4,5 & 1,5 & 3,8 & 1,6 & 2,1 & 1,0 & 1,0 & 1,1 & 0,2 \\
\hline Emprego/população & 67,5 & 32,5 & 67,9 & 34,5 & 95,4 & 36,8 & 94,8 & 43,9 & 85,1 & 24,2 & 81,7 & 29,4 \\
\hline
\end{tabular}

Fonte: OECD (2002)

${ }^{1}$ Refere-se a pessoas com idade entre 15 e 64 anos que estão empregadas ou na força de trabalho divididas pela população em idade de trabalhar.

${ }^{2}$ Em relação a força de trabalho. 
$\mathrm{Na}$ América Latina, o reduzido crescimento da demanda de trabalho agrícola traduziu-se na queda contínua da participação do setor primário em benefício de outros setores com maior dinamismo ocupacional. Embora a América Latina apresente características estruturais no mercado de trabalho diferente das apresentadas pela União Européia, observa-se a mesma tendência de crescimento do setor serviços neste período (tabela 7).

Tabela 7. Participação percentual relativa dos setores no total do emprego na América Latina.

\begin{tabular}{lcccc}
\hline Setor & 1990 & 1994 & 1997 & 1999 \\
\hline Agricultura & 23,3 & 22,5 & 21,0 & 20,5 \\
Indústria & 22,7 & 23,2 & 22,2 & 21,3 \\
Serviços & 54,0 & 54,3 & 56,8 & 58,0 \\
\hline
\end{tabular}

Fonte: CEPAL (2001)

Ao longo da década de 1990, as taxas de desemprego apresentadas pelos países da América Latina foram superiores aos países da União Européia (tabelas 8 e 9). $\mathrm{Na}$ América do Sul, o desemprego também atinge os jovens e as mulheres com maior intensidade (figura 2). 
Tabela 8. Taxa de desemprego na América Latina - 1990/1999.

\begin{tabular}{|c|c|c|c|c|c|c|c|c|c|c|c|c|}
\hline \multirow[b]{2}{*}{ Países } & \multicolumn{3}{|c|}{1990} & \multicolumn{3}{|c|}{1994} & \multicolumn{3}{|c|}{1997} & \multicolumn{3}{|c|}{1999} \\
\hline & Total & Homem & Mulher & Total & Homem & Mulher & Total & Homem & Mulher & Total & Homem & Mulher \\
\hline Argentina & 5,9 & 5,7 & 6,4 & 13,0 & 11,5 & 15,5 & 14,3 & 12,4 & 17,2 & 14,7 & 13,4 & 16,5 \\
\hline Bolívia & 9,4 & 9,5 & 9,1 & 3,2 & 3,4 & 2,9 & 3,7 & 3,7 & 3,7 & 7,1 & 6,0 & 8,5 \\
\hline Brasil & 4,5 & 4,8 & 3,9 & 7,4 & 6,4 & 8,9 & 8,0 & 6,7 & 10,0 & 11,4 & 9,4 & 14,1 \\
\hline Chile & 8,7 & 8,1 & 9,7 & 6,8 & 5,9 & 8,4 & 6,0 & 5,1 & 7,3 & 10,1 & 9,4 & 11,2 \\
\hline Colômbia & 9,3 & 6,7 & 13,0 & 8,0 & 5,4 & 11,6 & 11,8 & 9,7 & 14,7 & 19,2 & 16,2 & 23,0 \\
\hline Costa Rica & 5,3 & 4,9 & 6,2 & 4,2 & 3,7 & 5,1 & 5,8 & 5,3 & 6,7 & 6,1 & 5,3 & 7,4 \\
\hline Equador & 6,1 & 40,2 & 9,2 & 7,1 & 5,7 & 9,2 & 9,2 & 6,9 & 12,6 & 14,2 & 10,5 & 19,5 \\
\hline El Salvador & 9,9 & 10,0 & 9,7 & 6,8 & 8,3 & 4,9 & 7,3 & 8,8 & 5,5 & 6,9 & 8,9 & 4,6 \\
\hline Guatemala & 3,5 & 3,3 & 3,8 & $\ldots$ & $\ldots$ & $\ldots$ & $\ldots$ & $\ldots$ & $\ldots$ & 2,8 & 3,6 & 1,9 \\
\hline Honduras & 6,9 & 7,6 & 5,9 & 4,1 & 4,5 & 3,4 & 5,2 & 5,9 & 4,3 & 5,3 & 6,2 & 4,0 \\
\hline México & 3,3 & 3,4 & 3,1 & 4,5 & 5,1 & 3,6 & 5,1 & 5,8 & 3,9 & 3,2 & 3,6 & 2,6 \\
\hline Nicaragua & $\ldots$ & $\ldots$ & $\ldots$ & 14,1 & 16,5 & 10,8 & 13,1 & 13,6 & 12,6 & 13,8 & 14,0 & 13,6 \\
\hline Panamá & 18,6 & 15,9 & 22,8 & 15,7 & 12,4 & 21,0 & 15,4 & 13,3 & 18,2 & 13,1 & 10,6 & 17,0 \\
\hline Paraguai & 6,3 & 6,2 & 6,5 & 4,4 & 5,1 & 3,5 & 8,4 & 8,2 & 8,7 & 10,1 & 10,2 & 10,1 \\
\hline \multicolumn{13}{|l|}{ República } \\
\hline Dominicana & 19,7 & 11,3 & 31,5 & 17,0 & 12,1 & 24,8 & 17,0 & 10,9 & 26,0 & $\ldots$ & $\ldots$ & $\ldots$ \\
\hline Uruguai & 8,9 & 7,3 & 11,1 & 9,7 & 7,3 & 13,0 & 11,4 & 8,9 & 14,7 & 11,2 & 8,6 & 14,5 \\
\hline Venezuela & 10,2 & 11,2 & 8,4 & 8,9 & 9,1 & 8,3 & 10,6 & 9,0 & 13,6 & 14,5 & 13,6 & 16,1 \\
\hline
\end{tabular}

Fonte: CEPAL (2001) 
Tabela 9. Taxa de desemprego entre os Jovens com idade entre 15 e 24 anos na América Latina - 1990/1999.

\begin{tabular}{|c|c|c|c|c|c|c|c|c|c|c|c|c|}
\hline \multirow[t]{2}{*}{ Países } & \multicolumn{3}{|c|}{1990} & \multicolumn{3}{|c|}{1994} & \multicolumn{3}{|c|}{1997} & \multicolumn{3}{|c|}{1999} \\
\hline & Total & Homem & Mulher & Total & Homem & Mulher & Total & Homem & Mulher & Total & Homem & Mulher \\
\hline Argentina & 13,0 & 11,5 & 15,6 & 22,8 & 20,3 & 26,7 & 24,2 & 21,1 & 28,9 & 24,3 & 22,8 & 26,3 \\
\hline Bolívia & 17,4 & 18,2 & 16,5 & 5,8 & 6,3 & 5,2 & 6,4 & 5,8 & 7,1 & 15,3 & 12,5 & 18,5 \\
\hline Brasil & 8,3 & 8,7 & 7,7 & 14,3 & 12,4 & 17,0 & 15,1 & 12,8 & 18,2 & 21,7 & 18,4 & 26,2 \\
\hline Chile & 17,9 & 17,0 & 19,1 & 16,1 & 14,0 & 19,3 & 13,2 & 10,7 & 17,1 & 21,8 & 20,4 & 23,7 \\
\hline Colômbia & 19,7 & 15,3 & 24,8 & 16,2 & 11,9 & 21,0 & 24,3 & 20,7 & 28,3 & 36,6 & 32,0 & 41,6 \\
\hline Costa Rica & 10,5 & 9,8 & 11,6 & 9,7 & 8,6 & 11,6 & 13,0 & 11,4 & 16,2 & 14,8 & 14,8 & 14,9 \\
\hline Equador & 13,5 & 11,2 & 17,2 & 14,9 & 12,7 & 17,8 & 18,9 & 15,1 & 24,5 & 25,9 & 20,0 & 33,9 \\
\hline El Salvador & 19,3 & 17,7 & 21,3 & 14,0 & 15,4 & 11,9 & 14,6 & 16,1 & 12,4 & 13,9 & 16,2 & 10,6 \\
\hline Guatemala & 7,1 & 7,2 & 7,0 & $\ldots$ & $\ldots$ & $\ldots$ & $\ldots$ & $\ldots$ & $\ldots$ & 4,8 & 6,0 & 3,4 \\
\hline Honduras & 11,2 & 11,5 & 10,7 & 7,1 & 7,5 & 6,6 & 8,9 & 9,2 & 8,5 & 9,0 & 10,3 & 7,4 \\
\hline México & 8,1 & 8,4 & 7,6 & 9,4 & 10,0 & 8,3 & 12,5 & 13,8 & 10,3 & 7,4 & 8,1 & 6,2 \\
\hline Nicaragua & $\ldots$ & $\ldots$ & $\ldots$ & 20,1 & 20,3 & 19,7 & 20,9 & 18,9 & 23,8 & 20,9 & 17,9 & 25,8 \\
\hline Panamá & 35,1 & 31,9 & 39,9 & 31,0 & 27,5 & 36,9 & 31,5 & 29,2 & 34,6 & 26,9 & 22,5 & 33,5 \\
\hline Paraguai & 15,5 & 14,7 & 16,5 & 8,3 & 9,9 & 6,5 & 17,8 & 17,4 & 18,2 & 19,5 & 21,6 & 17,1 \\
\hline República & 34,1 & 22,3 & 47,3 & 30,6 & 24,0 & 39,9 & 27,8 & 20,0 & 38,2 & $\ldots$ & $\ldots$ & $\ldots$ \\
\hline \multicolumn{13}{|l|}{ Dominicana } \\
\hline Uruguai & 24,4 & 22,2 & 27,5 & 24,7 & 19,8 & 31,5 & 26,3 & 21,8 & 32,7 & 25,8 & 21,4 & 31,9 \\
\hline Venezuela & 19,3 & 19,9 & 18,0 & 17,1 & 17,2 & 17,0 & 19,8 & 16,4 & 26,6 & 25,7 & 22,2 & 32,6 \\
\hline
\end{tabular}

Fonte: CEPAL (2001) 


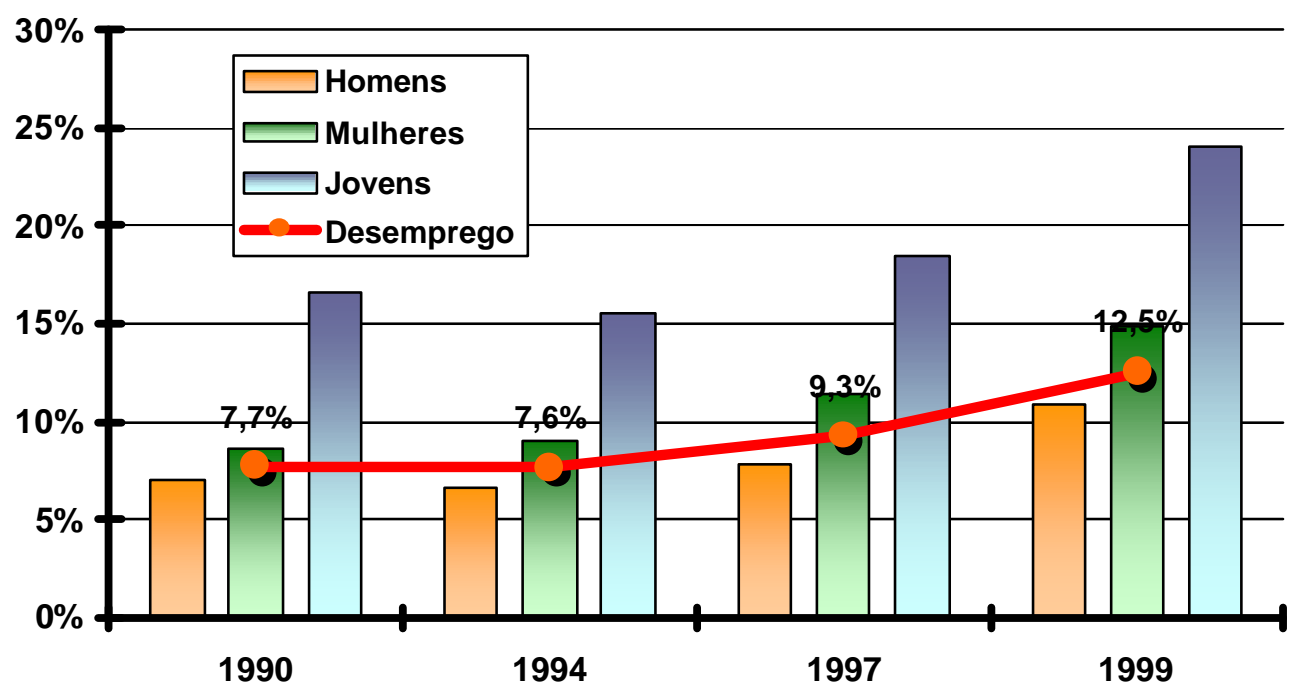

Figura 2 - Taxa de desemprego média na América do Sul.

No Brasil, os anos 1990 foram de queda no nível de emprego formal do país, justificada, de um lado pela mudança nas formas de utilização do trabalho por meio da terceirização realizada pelas empresas e, de outro, pela diminuição de oportunidades ocupacionais diretamente relacionadas à mudança na estrutura de produção (Baltar, 1998).

Baltar (1998) atribui estas mudanças na estrutura de produção a dois fatores: um deles está relacionado a elevação da produtividade do trabalho e o outro, a desintegração de algumas cadeias produtivas abaladas pela importação crescente de bens intermediários.

Nos primeiros anos da década a economia brasileira, medida pelo Produto Interno Bruto (PIB), diminuiu aproximadamente em 5\%. O setor agropecuário enfrentou o período recessivo com crescimento até 1992 e uma leve queda em 1993, recuperandose nos anos seguintes. O setor Industrial apresentou, no conjunto da indústria de transformação, uma queda de aproximadamente $15 \%$ e, conseqüentemente, foi o setor 
que apresentou maior redução no nível de emprego e renda. Em toda década, no entanto, o setor Serviços continuou crescendo (Baltar, 1998).

No início da década, a economia enfrentou uma redução do nível de atividade. Os anos de 1990 e 1992 foram de queda no nível do PIB. A partir de 1993 a economia volta, ainda que timidamente, a crescer. No entanto, a queda do emprego nos anos de recessão não foi compensada por um aumento da oferta de postos de trabalho quando a economia volta a apresentar taxas positivas de crescimento.

Isto se justifica, em parte, pelo aumento da produtividade alcançado por meio de mudanças organizacionais, implementação de novos processos e equipamentos e da terceirização ${ }^{1}$ de atividades, as quais permitiram aumentar a produção final, principalmente de bens duráveis de consumo, sem aumentar a quantidade de empregos na indústria do país (Baltar, 1998; Neri et al., 2000).

Mattoso (1999) argumenta que o processo de desestruturação do mercado de trabalho ocorrido a partir da segunda metade dos anos noventa, apresentou uma redução da capacidade de geração de empregos formais e de novos postos de trabalho.

Guimarães (2002) sugere que sucessivas ondas de impactos negativos ocorreram sobre o mercado de trabalho no Brasil contribuindo, de alguma forma, para o sua desestruturação e que a precarização das relações de trabalho pode ser considerada como um dos principais impactos negativos ocorridos neste período.

Segundo o autor, “(...) a relação fundamental de inclusão das pessoas (em particular os jovens) na sociedade, representada pelo trabalho assalariado com registro, perde importância no conjunto das ocupações existentes. (...) isto se traduz não só na incapacidade de a economia absorver

\footnotetext{
${ }^{1}$ O processo de terceirização é um tipo de descentralização produtiva, cuja lógica esta na focalização da produção, processo pelo qual a empresa tende a concentrar seus esforços e a se especializar na produção daquelas mercadorias sobre as quais ela detém evidentes vantagens competitivas (Alves, 2000), diferentemente do conceito de terciarização, que pode ser entendida como aumento das atividades e ocupações econômicas no setor serviços (terciário) (Cuadrado-Roura, 1998;Cardoso,2001).
} 
no mercado de trabalho as pessoas por meio dessa relação, mas na diminuição, em termos absolutos, de contingentes de pessoas que já haviam integrado como assalariados com registro nas fases anteriores do desenvolvimento do país" (Guimarães, 2002 p.191).

Pochmann (1999) atribui a situação de insuficiência de emprego e de renda nos vários segmentos às baixas taxas de crescimento da economia e ao predomínio de políticas neoliberais. A instabilidade dos contratos de trabalho, principalmente os decorrentes da alta rotatividade nos empregos secundários (terceirização e subcontratação), é apresentada como uma das pressuposições de modernidade dos novos processos de gestão da mão-de-obra.

Lacerda (2000) argumenta que a década de 1990 foi negativa para o mercado de trabalho brasileiro. O principal indicador dessa situação está relacionado ao aumento do número de desempregados. Acrescenta ainda que, de 1991 a 1998, aumentou o número de trabalhadores sem carteira assinada e dos trabalhadores por conta própria, indicando que o tamanho relativo do mercado formal de trabalho também diminuiu.

Todos estes trabalhos não tocam num ponto importante, ou seja, na dinâmica da oferta de postos de trabalho, não apenas no nível das atividades primárias, secundárias e terciárias, mas no nível dos setores que compõem estas atividades e sua interdependência econômica.

Deste modo, a contribuição desta pesquisa é no sentido de evidenciar o impacto das mudanças estruturais no mercado de trabalho brasileiro, no que diz respeito à geração de postos de trabalho nos setores da economia. 


\section{EFEITOS DA ESTABILIZAÇÃO DO NÍVEL DE PREÇOS E DA ABERTURA ECONÔMICA SOBRE A OFERTA DE POSTOS DE TRABALHO NO BRASIL: UM ESTUDO PARA A DÉCADA DE 1990}

\section{Resumo}

Este artigo analisa os efeitos do plano de estabilização do nível de preços e do processo de abertura econômica nos setores produtivos, utilizando as matrizes insumo-produto de 1990 a 1999. É feita uma análise da estrutura da economia a partir de multiplicadores de produção e emprego, indicadores de geração de empregos diretos, indiretos e induzidos, índices de ligação e do índice de turbulência. Para melhor exploração dos dados os setores foram agregados e analisados em sete macros setores. Os resultados obtidos indicam que o processo de abertura provocou efeitos positivos e negativos na estrutura produtiva. Setores como a agropecuária modernizaram seu processo de produção e, ao mesmo tempo em que aumentaram sua produtividade diminuíram sua capacidade de geração de postos de trabalho. O setor industrial apresentou-se dependente de insumos importados e diminuiu sua capacidade de gerar empregos, entretanto o setor serviços consolidou-se como grande gerador ou absorvedor de mão-de-obra neste período.

Palavras-chave: Abertura comercial, Insumo-produto, Mercado de trabalho, Economia brasileira.

\section{Abstract}

This article analyses the effects of the price level stabilization and the economic openness on the Brazilian productive sectors using the yearly input-output tables for the 1990s. The main indicators used were: a) output and employment multipliers; b) 
generation of direct, indirect and induced employments; c) backward and forward linkages (Hirschmann-Hasmussen and Pure); and d) turbulence. Aiming at a better understanding of the changes that had impacted the Brazilian economy, the results were aggregated into seven macro sectors. The study shows that the openness process had an impact on the productive structure with sectors gaining and losing in this process. The agricultural sector went to a process of modernization in which, on one hand it increased its links in the economy, but, on the other hand reduced its capacity of generate employment. The industrial sector became more dependable on imported inputs for its production process, with a reduction in its level of employment. To the service sector was left the task of absorb the workers freed and/or not absorbed by the other sectors.

Key Words: Brazilian Economy, Globalization, Input-Output, Labor Market.

\section{Introdução}

Nos anos 1990 a economia brasileira passou por mudanças na estrutura produtiva e no emprego em consequiência do plano de estabilização do nível de preços e do processo de abertura comercial.

Este estudo verifica os efeitos destas mudanças nos setores produtivos e na dinâmica do emprego, utilizando as matrizes de insumo-produto para a década de 1990. Isto é feito por intermédio da análise do processo recente de transformação, tanto na estrutura produtiva, quanto no emprego em 31 setores econômicos, os quais foram, em seguida, agregados em sete macro setores, buscando facilitar a apresentação e a compreensão dos resultados (tabela A1 do anexo).

O trabalho é composto por cinco seções, além desta introdução. Inicialmente são apresentados os principais acontecimentos econômicos que afetaram a economia brasileira nos anos 1990. Em seguida, são feitas algumas considerações a respeito dos impactos destes acontecimentos sobre o mercado de trabalho. A quarta seção apresenta a metodologia utilizada no trabalho. A quinta seção caracteriza a estrutura da economia brasileira a partir dos indicadores definidos na metodologia e 
mostra os impactos da abertura econômica no mercado de trabalho. A última seção traz as considerações finais.

\section{0 cenário macroeconômico}

Ao final da década de 1980 a economia brasileira era caracterizada pela estagnação do nível de atividade, desequilíbrios macroeconômicos e hiperinflação. Esgotada a estratégia de desenvolvimento calcada na substituição de importações,

iniciou-se um processo - que viria a consolidar-se na década de 1990 - de redefinição do papel do estado na economia, o qual deixou a posição de Estado-Empresário e caminhou no sentido do Estado regulador e fiscal (Pinheiro et al., 1999).

No começo da década de 1990 o Brasil ainda experimentava índices altos de inflação, déficit fiscal elevado e taxa de câmbio desvalorizada (Pinheiro et al, 1999).

As transformações econômicas que caracterizaram o país nos anos 1990 são resumidas na figura 1. 


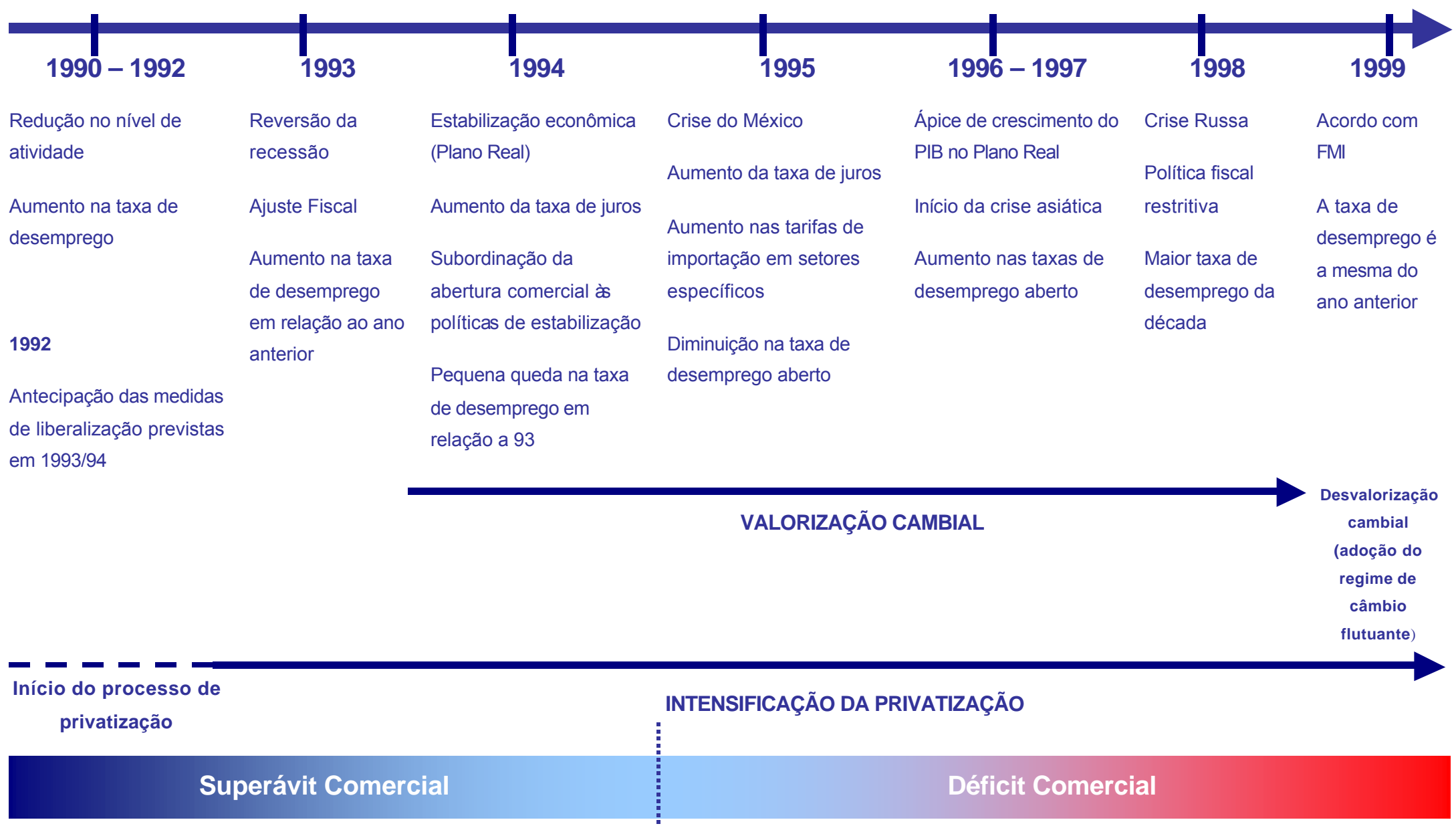

Figura 1 - Principais acontecimentos que afetaram a economia brasileira na década de 1990. 
Os indicadores da Tabela 1 refletem a situação econômica do país e ilustram os fenômenos mostrados na figura 1.

Tabela 1. Principais indicadores da economia brasileira na década de 1990.

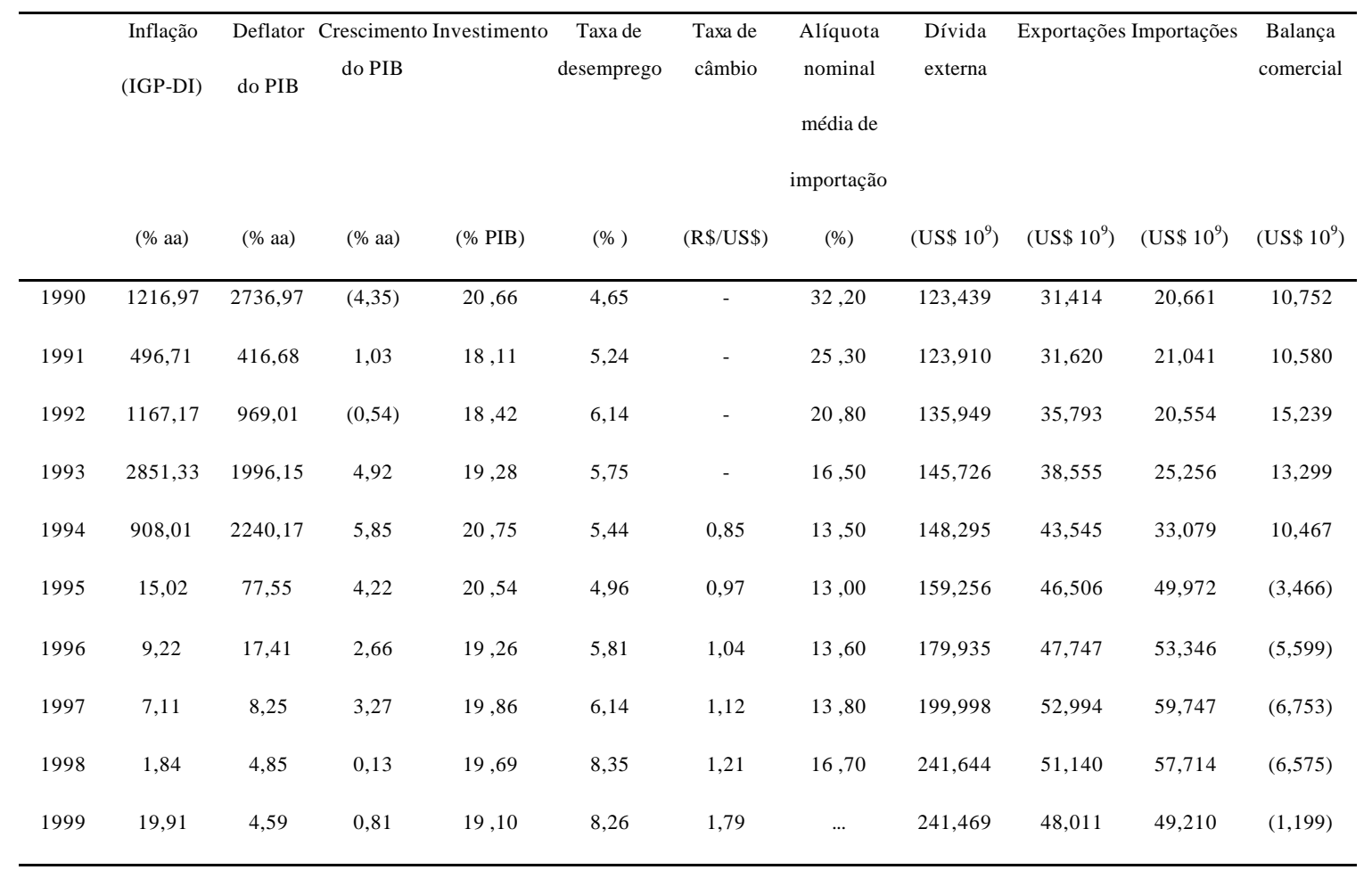

Fonte: IPEA (2002)

\section{0 mercado de trabalho: algumas considerações}

No final da década de 1990, aumenta a preocupação com a velocidade no aumento da taxa de desemprego, que passa de 4,65\% em 1990 para 8,26\% em 1999 (tabela 1). Por conta disto, vários autores debruçaram-se sobre o tema.

Para Pinheiro et al.(1999) o nível de emprego na década de 1990 foi afetado pelo custo da mão-de-obra (incluindo os custos impostos pela legislação trabalhista vigente no país), pelo processo tecnológico e a situação conjuntural da demanda. 
Para os autores, "(...) os métodos de reestruturação organizacional e produtiva das empresas, traduzidos no enxugamento do quadro de pessoal, reduziram muito a utilização de mão-de-obra por unidade produzida, acarretando uma tendência à diminuição da demanda de trabalho por parte das empresas" (Pinheiro et al., 1999, p. $32)$.

Além disso, o cenário decorrente da abertura comercial desencadeou diversos efeitos na economia.

Ramos \& Reis (1997) destacam que o ajustamento observado no início da década de 1990 influenciou o nível do emprego no setor industrial. Segundo eles, "o esforço da indústria em resposta ao processo de abertura comercial envolveu a reestruturação organizacional e produtiva das empresas, passando pelo enxugamento dos quadros de pessoal" (Ramos \& Reis, 1997, p. 4).

Nesta linha, Arbache \& Corseuil (2001) ressaltam que de um lado a reforma comercial foi diferenciada por indústria e de outro, o grau de competitividade das firmas é heterogêneo dentro de uma mesma indústria. Deste modo, as indústrias podem ter sido atingidas de formas diferentes, o que pode ter provocado realocação intersetorial de fatores, em particular de trabalhadores.

Da mesma forma que isto ocorreu no mercado de bens, as mudanças no mercado de trabalho dependem das imperfeições do processo, isto é, quanto maior a liberdade de funcionamento do mercado de trabalho, maior será a realocação do emprego interindustrial e, conseqüentemente, existirão alterações nos salários relativos (Arbache \& Corseuil, 2001).

Moreira \& Najberg (1997) e Barros, Mendonça \& Foguel (1996), apontaram a abertura comercial como a principal responsável pela queda no emprego nos anos 90.

Carvalheiro (2000), avalia alguns efeitos das reformas neoliberais da primeira metade da década de 1990, usando as matrizes de relações inter-setoriais para o período de 1990-1996, tendo como pano de fundo a abertura comercial. 
Segundo o autor, "a reestruturação da indústria, iniciada em 1990, usou como um dos seus fundamentos a diminuição da quantidade de trabalho na produção. $\mathrm{O}$ processo visava, portanto, reduzir custos para enfrentar o contexto de persistente instabilidade macroeconômica interna e para capacitar-se à concorrência externa, dada à abertura da economia" (Carvalheiro, 2000, p. 87).

$\mathrm{O}$ autor afirma que o aumento das importações, favorecido pela abertura comercial e pela política cambial, fez com que houvesse uma redução do número de pessoas ocupadas na maioria dos setores (Carvalheiro, 2000).

Um ponto importante e não considerado é a análise dos efeitos setoriais e inter-setoriais das transformações ocorridas na oferta de postos de trabalho, buscando identificar os setores com maior potencial de geração de empregos e aqueles que além de diminuir sua capacidade de gerar novos empregos desempregam mão-de-obra.

\section{Metodologia}

Esta seção descreve a metodologia empregada para possibilitar tal identificação, introduzindo os conceitos básicos utilizados para a análise, tanto da estrutura produtiva quanto do mercado de trabalho no Brasil.

\subsection{Modelo de insumo-produto}

Os impactos das mudanças ocorridas nos setores produtivos e no mercado de trabalho do Brasil no período 1990-1999 são percebidos por intermédio da análise de insumo-produto, proposta inicialmente por Leontief (1986).

Este método possibilita avaliar e analisar as relações existentes na cadeia produtiva de um produto e de seu consumo em uma economia nacional. As tabelas de insumo-produto descrevem o fluxo de bens e serviços entre os setores individuais de uma economia durante um determinado período de tempo.

Numa economia composta por $n$ setores, as relações fundamentais da teoria de insumo-produto são obtidas a partir da equação (1): 


$$
\sum_{j=1}^{n} z_{i j}+C_{i}+G_{i}+I_{i}+E_{i}=X_{i}
$$

onde:

$z_{i j}$ é o valor monetário do fluxo de um setor $i$ para um setor $j$;

$C_{i}$ é a produção do setor $i$ comprada pelas famílias;

$G_{i}$ é a produção do setor $i$ comprada pelo governo;

$I_{i}$ é a produção do setor $i$ destinada ao investimento;

$E_{i}$ é a produção do setor $i$ destinada a exportação; e

$X_{i}$ é a produção doméstica total do setor $i$, composta da demanda final e insumos intermediários.

A demanda final da produção do setor $i$, representada por $Y_{i}$ é composta por $C_{i}, G_{i}, I_{i}$ e $E_{i}$. A produção total do setor $i$ será $X_{i}$.

O modelo de insumo-produto assume que os fluxos interindustriais do setor $i$ para o setor $j$ obedecem a uma relação exata, dada por um coeficiente técnico $a_{i j}$. Dito de outra forma, este coeficiente mostra a quantidade de insumo do setor $i$ necessária para a produção de uma unidade de produto total do setor $j$, ou seja,

$$
a_{i j}=\frac{z_{i j}}{X_{j}}
$$

Deste modo, para cada setor da economia pode-se escrever

$$
\sum_{j=1}^{n} a_{i j} X_{j}+Y_{j}=X_{i}
$$

O conjunto dos coeficientes técnicos $a_{i j}$ irá formar a matriz $\mathbf{A}$, de dimensão $n \times n$, onde $n$ é o número de setores utilizados no modelo. Cada coluna da matriz A descreve a estrutura tecnológica do setor correspondente.

Em notação matricial, pode-se reescrever a equação (3) como: 


$$
\mathbf{A X}+\mathbf{Y}=\mathbf{X}
$$

onde

$$
\mathbf{A}=\left[\begin{array}{llllll}
a_{11} & a_{12} & \ldots & a_{1 i} & \ldots & a_{1 n} \\
a_{21} & a_{22} & \ldots & a_{2 i} & \ldots & a_{2 n} \\
\vdots & \vdots & & \vdots & & \vdots \\
a_{n 1} & a_{n 2} & \ldots & a_{n i} & \ldots & a_{n n}
\end{array}\right] ; \mathbf{X}=\left[\begin{array}{c}
X_{1} \\
X_{2} \\
\vdots \\
X_{n}
\end{array}\right] \text { e } \mathbf{Y}=\left[\begin{array}{c}
Y_{1} \\
Y_{2} \\
\vdots \\
Y_{n}
\end{array}\right]
$$

De acordo com Miller e Blair (1985), as variações ocorridas na demanda final $\mathbf{Y}$, são determinadas exogenamente e a produção total $\mathbf{X}$, pode ser obtida pela equação

$$
\mathbf{X}=(\mathbf{I}-\mathbf{A})^{-1} \mathbf{Y}
$$

Em (6), $(\mathbf{I}-\mathbf{A})^{-1}$ é a matriz inversa de Leontief, a qual apresenta os coeficientes técnicos de insumos diretos e indiretos utilizados no sistema produtivo. Esta matriz capta os efeitos diretos e indiretos das modificações exógenas da demanda final sobre a produção dos $n$ setores.

O modelo acima assume que os elementos da demanda final (consumo das famílias, consumo do governo [gastos da administração pública], investimentos para formação de capital fixo, exportações e variação dos estoques) são exógenos..

Dado um choque exógeno na demanda final, a matriz $\mathbf{X}$ possibilita avaliar os impactos resultantes não só sobre o próprio setor, mas também sobre os demais setores.

Numa outra versão do modelo, considera-se a inter-relação existente entre o consumo das famílias e a renda originada do trabalho e da produção de cada setor. Isto torna possível transferir o consumo das famílias da demanda final para a matriz $\mathbf{X}$. Isto é feito acrescentando-se uma nova linha e uma nova coluna à matriz $\mathbf{X}$, cuja dimensão passa a ser $(n+1)$. 
De modo similar ao modelo anterior, pode-se obter os coeficientes técnicos para o setor consumo das famílias, apresentados pela equação (6):

$$
a_{i, n+1}=\frac{z_{i, n+1}}{X_{n+1}} \quad \text { ou } \quad z_{i, n+1}=a_{i, n+1} X_{n+1}
$$

A forma genérica deste modelo pode ser escrita também em notação matricial como segue:

$$
\overline{\mathbf{A}}=\left[\begin{array}{c:c}
\mathbf{A} & \mathbf{H}_{\mathbf{C}} \\
\hdashline \mathbf{H}_{R} & 0
\end{array}\right], \overline{\mathbf{X}}=\left[\begin{array}{c}
X \\
\hdashline X_{n+1}
\end{array}\right] \text { e } \overline{\mathbf{Y}}=\left[\begin{array}{c}
Y^{*} \\
\hdashline Y_{n+1}^{*}
\end{array}\right]
$$

onde:

$\overline{\mathbf{A}}$ é a matriz dos coeficientes técnicos com o setor consumo das famílias endogeneizado, cuja dimensão é $(n+1 \times n+1)$;

$\mathbf{H}_{\mathbf{C}}$ é o vetor coluna dos $n$ coeficientes técnicos que representam a estrutura do consumo das famílias, ou seja, quanto as famílias consomem de cada um dos $n$ setores da economia, tal que $a_{i, n+1}(i=1, \cdots, n)$;

$\mathbf{H}_{R}$ é o vetor linha dos $n$ coeficientes técnicos que mostram como o trabalho das famílias é usado como insumo em cada um dos $n$ setores. Visto de outra forma, na medida em que o pagamento dos $n$ setores às famílias constitui nada mais que sua remuneração, o vetor coluna $\mathbf{H}_{R}$ representa os valores recebidos pelas famílias em pagamento por seu trabalho. $\operatorname{Logo}, a_{n+1, j}(j=1, \cdots, n)$;

$\overline{\mathbf{X}}$ é o vetor do valor bruto da produção, com dimensão $(n+1) \times 1$;

$Y^{*}$ é o vetor coluna da demanda final incluindo o setor consumo das famílias para os outros $n$ setores;

$\overline{\mathbf{Y}}$ é a demanda final excluindo o consumo das famílias.

Após a endogeinização do consumo das famílias o modelo de Leontief, pode ser escrito como: 


$$
\overline{\mathbf{X}}=(\mathbf{I}-\overline{\mathbf{A}})^{-1} \overline{\mathbf{Y}}
$$

ou

$$
\left[\begin{array}{c}
X \\
\hdashline X_{n+1}
\end{array}\right]=\left[\begin{array}{c:c}
I-A & -H_{C} \\
\hdashline-H_{R} & 1
\end{array}\right]^{-1}\left[\begin{array}{c}
Y^{*} \\
\hdashline Y_{n+1}^{*}
\end{array}\right]
$$

\subsection{Análise da estrutura da economia}

Os multiplicadores derivados da matriz insumo-produto avaliam o impacto de uma variação na demanda final sobre a variável econômica de interesse (produção, renda, emprego, etc).

\subsubsection{Multiplicadores de produção e de emprego}

Os multiplicadores de produção e emprego podem ser divididos em dois grupos: multiplicadores do tipo I e do tipo II.

Os multiplicadores de produção do tipo I calculam o quanto cada um dos setores analisados precisa produzir para satisfazer uma unidade adicional de demanda final. Analogamente, os multiplicadores de emprego do tipo I mostram quanto cada um dos setores necessita empregar (em termos de pessoas) por unidade monetária adicional de demanda final. Ambos consideram exógeno o consumo das famílias.

Se $\mathbf{B}=(\mathbf{I}-\mathbf{A})^{-1}$, o multiplicador setorial de produção do setor $j$ será

$$
M S_{j}=\sum_{i=1}^{n} b_{i j}, \quad j=1, \ldots, n
$$

onde $M S_{j}$ é o multiplicador de produção do tipo I e $b_{i j}$ é um elemento da matriz inversa de Leontief.

O resultado obtido representa o valor total da produção de toda a economia que é ativado para atender a variação de uma unidade na demanda final do setor $j$. 
O multiplicador setorial de emprego fornece o número de pessoas empregadas (ou desempregadas) por pessoa adicional ocupada (ou desocupada) por conta de uma variação na demanda final do setor.

Enquanto os multiplicadores do tipo I fornecem os impactos diretos (sobre o próprio setor) e indiretos (sobre os demais setores), os multiplicadores do tipo II fornecem os impactos diretos, indiretos e induzidos (originados da inter-relação do consumo das famílias com a renda e a produção dos vários setores).

O multiplicador de empregos do tipo I é dado por

$$
M E_{j}=\sum_{i=1}^{n} \frac{w_{n+1, i} \cdot b_{i j}}{w_{n+1, j}}
$$

onde $w_{n+1, i}$ é o coeficiente de empregos (em número de pessoas) por unidade monetária produzida, $b_{i j}$ é um elemento da matriz inversa de Leontief e $w_{n+1, j}$ é o montante de empregos diretos gerados no setor $j$.

Os multiplicadores de produção e emprego do tipo II são conceitualmente idênticos aos do tipo I, no entanto, mostram o efeito da endogeneização do consumo das famílias sobre o aumento da produção quando a demanda final é acrescida de uma unidade monetária.

No caso do multiplicador de produção do tipo II, pode-se avaliar os efeitos diretos, indiretos e induzidos de uma variação na demanda final do setor sobre sua produção. Igualmente, na análise do multiplicador do emprego do tipo II, observamse os efeitos diretos, indiretos e induzidos de uma variação na demanda final do setor sobre a geração de postos de trabalho.

Os multiplicadores do tipo II são obtidos a partir da matriz inversa de Leontief $\quad \overline{\mathbf{B}}=(\mathbf{I}-\overline{\mathbf{A}})^{-1}$ incluindo o consumo das famílias, conforme explicitado na equação (9).

A partir desta matriz $\overline{\mathbf{B}}$ são obtidos os seguintes multiplicadores: 


$$
M \bar{S}_{j}=\sum_{i=1}^{n} \bar{b}_{i j}, \quad j=1, \ldots, n
$$

onde $M \bar{S}_{j}$ é o multiplicador de produção do tipo II e $\bar{b}_{i j}$ é um elemento qualquer da matriz $\overline{\mathbf{B}}$.

De modo similar, a equação do multiplicador de emprego do tipo II é:

$$
M \bar{E}_{j}=\sum_{i=1}^{n} \frac{w_{n+1, i} \cdot \overline{b_{i j}}}{w_{n+1, j}}
$$

onde $w_{n+1, i}$ é o coeficiente de trabalho físico (número de empregos gerados por unidade monetária produzida), $\bar{b}_{i j}$ é um elemento da matriz $\overline{\mathbf{B}}=(\mathbf{I}-\overline{\mathbf{A}})^{-1}$ e $w_{n+1, j}$ é o montante de empregos diretos gerados no setor $j$.

Pode-se também avaliar a geração de empregos resultante de cada unidade monetária mobilizada na produção de cada setor.

Os indicadores de geração de empregos diretos são os próprios elementos do vetor-linha dos coeficientes $w_{n+1, i}$. Os indicadores de geração de empregos indiretos são obtidos pelo seguinte procedimento: inicialmente multiplica-se o vetor-linha dos coeficientes de emprego pela matriz inversa de Leontief. Em seguida, subtrai-se deste vetor-linha o vetor-linha dos coeficientes diretos. O resultado (diferença entre os dois vetores) é o efeito indireto em cada setor.

Para obter os indicadores de geração de emprego induzido deve-se, inicialmente multiplicar o vetor-linha dos coeficientes de emprego pela inversa de Leontief considerando o consumo das famílias endógeno. Em seguida, multiplica-se o vetor-linha dos coeficientes de emprego pela inversa de Leontief, considerando o consumo exógeno. Os indicadores da geração de emprego induzida serão obtidos pela diferença entre os dois produtos.

O indicador da geração de empregos total é obtido somando-se os indicadores de geração de empregos direto, indireto e induzido. 


\subsection{2 Índice de turbulência}

Um indicador complementar da dinâmica setorial do mercado de trabalho é o índice de turbulência, que capta a movimentação com respeito ao emprego de um determinado setor num dado período de tempo.

Ele indica tão somente a variação na estrutura setorial do emprego ocorrida entre dois instantes do tempo (Néri et al., 2000). Alternativamente, ele pode ser interpretado como sendo a fração mínima da população de interesse que teria de ser realocada para que a estrutura inicial fosse restabelecida (Barros et al., 1998).

Por construção, este índice não mostra se houve oferta adicional ou redução da oferta de postos de trabalho no setor, nem qualquer espécie de ligação intersetorial da oferta destes postos. Para isto é necessário recorrer a indicadores adicionais.

Em termos matemáticos, ele é definido como

$$
T=\frac{1}{2} \sum_{g=1}^{G}\left|\alpha_{g, t+n}-\alpha_{g, t}\right|
$$

onde $\alpha_{g, t}$ é a proporção do emprego no setor $g$ em relação ao emprego total, no instante de tempo $i$.

Logo, quanto maior o valor de $T$, maior terá sido a movimentação no setor no período de tempo analisado.

\subsection{3 Índices de Ligação}

- Índices de ligação de Rasmussen e Hirschman

A partir da matriz inversa de Leontief é possível identificar quais são os setores-chave da economia, tomando-se por base as relações inter-setoriais.

Os índices de Rasmussen-Hirschmann se prestam a esta finalidade e dividem-se em dois tipos: 
a) índice de ligação para trás, que mostra o quanto o setor demanda de outros setores; e,

b) índice de ligação para frente indicando o quanto os outros setores demanda do setor em análise.

Os índices partem da matriz inversa de Leontief $\mathbf{B}=(\mathbf{I}-\mathbf{A})^{-1}$. A partir dela obtêm-se os índices de ligações para trás $\mathrm{H}_{j}$, chamado de "poder de dispersão", e os índices de ligações para frente $\mathrm{H}_{i}$, "sensibilidade da dispersão".

Estes índices são calculados, respectivamente, por:

$$
\begin{aligned}
& H_{j}=\frac{\left(\frac{B_{*_{j}} / n}{n}\right)}{B^{*}} \\
& \left.H_{i}=\frac{\left(B_{i^{*}} / n\right.}{B^{*}}\right)
\end{aligned}
$$

onde:

$b_{i j}$, é um elemento qualquer da matriz $\mathbf{B}$,

B* é a média de todos os elementos da matriz $\mathbf{B}$,

$\mathrm{B}_{* \mathrm{j}}$ é a soma de uma das colunas de B,

$\mathrm{B}_{\mathrm{i}^{*}}$ é a soma de uma linha da matriz $\mathrm{B}$, e

$n$ é o número de setores da economia.

Para que um setor seja considerado "chave" ele deve apresentar um índice maior que a média da economia.

- Índices Puros de Ligação

Os índices de ligação de Rasmussen-Hirschman não consideram os níveis de produção de cada setor analisado. As tentativas de resolver ou minimizar esta deficiência tiveram início com Cella (1984) e Clements (1990). Guilhoto et al. (1994) 
utilizaram os conceitos desenvolvidos por estes autores para calcular o índice puro de ligação, o qual foi aprimorado em Guilhoto et al. (1996).

A abordagem proposta pelos autores determina a importância do setor para o resto da economia em termos da produção de cada setor e da interação deste com outros setores, minimizando as limitações dos índices de ligações para frente e para trás.

Em Guilhoto et al. (1996), o cálculo dos índices puros de ligação inicia-se pela definição de uma matriz A, que contém os coeficientes de insumos diretos do setor (ou região) $j$ e do resto da economia:

$$
A=\left[\begin{array}{cc}
A_{j j} & A_{j r} \\
A_{r j} & A_{r r}
\end{array}\right]
$$

onde:

$\mathbf{A}_{j j}$ e $\mathbf{A}_{r r}$ são respectivamente matrizes que representam insumos diretos do setor $j$ e do resto da economia; e,

$\mathbf{A}_{r j}$ e $\mathbf{A}_{j r}$ representam matrizes dos insumos diretos comprados pelo setor $j$ do resto da economia e os insumos diretos comprados pelo resto da economia do setor $j$.

A matriz inversa de Leontief $(\mathbf{L})$, quando se considera a matriz $\mathbf{A}$ acima, é dada pela expressão:

$$
\mathbf{L}=(\mathbf{I}-\mathbf{A})^{-1}=\left[\begin{array}{ll}
\mathbf{L}_{j j} & \mathbf{L}_{j r} \\
\mathbf{L}_{r j} & \mathbf{L}_{r r}
\end{array}\right]=\left[\begin{array}{cc}
\Delta_{j j} & 0 \\
0 & \Delta_{r r}
\end{array}\right]\left[\begin{array}{cc}
\Delta_{j} & 0 \\
0 & \Delta_{r}
\end{array}\right]\left[\begin{array}{cc}
\mathbf{I} & \mathbf{A}_{j r} \Delta_{r} \\
\mathbf{A}_{r j} & \mathbf{I}
\end{array}\right]
$$

onde:

$\Delta_{\mathrm{j}}=\left(I-A_{\mathrm{jj}}\right)^{-1}$

é interação do setor $j$ com ele mesmo;

$\Delta_{\mathrm{r}}=\left(I-A_{\mathrm{rr}}\right)^{-1}$

é interação do restante da economia com ela própria; 
$\Delta_{\mathrm{jj}}=\left(I-\Delta_{\mathrm{j}} A_{\mathrm{jr}} \Delta_{\mathrm{r}} A_{\mathrm{rj}}\right)^{-1}$

é a quantidade produzida pelo setor $j$ para atender as necessidades do restante da economia e esta às suas necessidades;

$$
\Delta_{\mathrm{rr}}=\left(I-\Delta_{\mathrm{r}} A_{\mathrm{rj}} \Delta_{\mathrm{j}} A_{\mathrm{jr}}\right)^{-1}
$$

é o quanto o restante da economia terá que produzir para o setor $j$ para que este atenda suas necessidades.

A partir da matriz obtida em (18) e aplicando a decomposição descrita acima, obtém-se:

$$
\left[\begin{array}{l}
X_{j} \\
X_{i}
\end{array}\right]=\left[\begin{array}{cc}
\Delta_{j j} & 0 \\
0 & \Delta_{r r}
\end{array}\right]\left[\begin{array}{cc}
\Delta_{j} & 0 \\
0 & \Delta_{r}
\end{array}\right]\left[\begin{array}{cc}
I & A_{j r} \Delta_{r} \\
A_{r j} \Delta_{j} & I
\end{array}\right]\left[\begin{array}{l}
Y_{j} \\
Y_{r}
\end{array}\right]
$$

Realizando a multiplicação do lado direito da equação, obtém-se:

$$
\left[\begin{array}{c}
X_{j} \\
X_{r}
\end{array}\right]=\left[\begin{array}{cc}
\Delta_{j j} & 0 \\
0 & \Delta_{r r}
\end{array}\right]\left[\begin{array}{l}
\Delta_{j} Y_{j}+\Delta_{j} A_{j r} \Delta_{r} Y_{r} \\
\Delta_{r} A_{r j} \Delta_{j} Y_{j}+\Delta_{r} Y_{r}
\end{array}\right]
$$

sendo que o termo $\mathrm{A}_{j r} \Delta_{r}$ é o impacto direto da demanda final do resto da economia sobre o setor $j$, em outras palavras, determina o valor da importação oriunda do setor $j$ necessária para que o resto da economia realize sua produção dada a demanda $\mathrm{Y}_{r}$. De modo similar, $\mathrm{A}_{r j} \Delta_{j} \mathrm{Y}_{j}$ será a importação do resto da economia para que o setor j possa atender sua demanda final. (Guilhoto, Hewigs e Sonis, 1998).

Assim, a partir desta expressão os índices puros de ligações podem ser obtidos.

O índice puro de ligação para trás (IPBL) é obtido de:

$$
\mathrm{IPBL}=\Delta_{\mathrm{r}} A_{\mathrm{rj}} Y_{\mathrm{j}}
$$

e refere-se ao impacto puro da produção do setor $j$ na produção do setor $r$ sem considerar a demanda do setor $j$ por seus próprios insumos e a demanda do resto da economia por insumos do setor $\mathrm{j}$. 
O índice puro de ligação para frente (IPFL) é definido como:

$$
\mathrm{IPFL}=\Delta_{\mathrm{j}} A_{\mathrm{jr}} \Delta_{\mathrm{r}} Y_{\mathrm{r}}
$$

e refere-se ao impacto direto da demanda final do resto da economia sobre a produção do setor $j$.

O índice puro total será a soma dos dois índices, ou seja:

$$
I P T L=I P B L+I P F L
$$

Pode-se também normalizar os índices puros de ligação, visando melhor observar sua magnitude em relação aos valores médios da economia.

\section{Resultados}

Esta seção mostra os resultados obtidos a partir da metodologia apresentada na sessão anterior. Foram utilizadas as tabelas insumo-produto para o Brasil nos anos de 1990 a 1999. As tabelas de 1990 a 1996 foram calculadas pelo Instituto Brasileiro de Geografia e Estatística (IBGE), enquanto que as tabelas para 1997 a 1999 foram estimadas conforme metodologia proposta por Guilhoto et al.(2002), utilizando dados das Contas Nacionais publicados pelo IBGE.

As tabelas de insumo-produto foram calculadas para 31 setores (Anexo A), os quais foram posteriormente agregados em sete macro-setores ${ }^{1}$.

Apresenta-se, em primeiro lugar, a análise sobre a estrutura produtiva e, em seguida, os efeitos da abertura econômica (importações e exportações) durante os anos noventa.

\subsection{Estrutura Produtiva}

O valor de produção por produto é dado, segundo IBGE (1997), pelo preço de fábrica dos produtos acabados vendidos, incorporados aos estoques ou ao capital fixo, transferidos para outros estabelecimentos, distribuídos gratuitamente ou produzidos pelas famílias para consumo próprio. Inclui também, no caso de bens, a

\footnotetext{
${ }^{1}$ Os resultados para os 31 setores encontram-se no anexo.
} 
variação dos estoques de produtos em elaboração e, no caso de serviços, a receita por serviços mercantis prestados, produzidos tanto na sua atividade característica como em quaisquer outras.

$\mathrm{Na}$ produção total da economia neste período, o setor agropecuária apresentou um pequeno aumento na sua participação de aproximadamente $6 \%$ para $7 \%$ no período de 1990 a 1999, seguido pelo setor de extração de petróleo, gás natural, carvão e outros combustíveis. Em contrapartida o setor industrial e construção civil apresentaram redução nas suas participações, a indústria que em 1990 correspondia a $37 \%$ passa a $33 \%$ em 1999, a construção civil que tinha participação em torno de $10 \%$ em 1990 reduz para aproximadamente 8\%. Os Serviços industriais de utilidade pública apresentaram um pequeno aumento de $2 \%$ para $3 \%$ no mesmo período, que pode ser atribuído à utilização intensiva de energia. Verifica-se também que o setor serviços apresentou o maior crescimento na participação dos setores na economia passando de $42 \%$ para $46 \%$ aproximadamente (tabela 2 e figura 2 ).

Tabela 2. Participação dos Macros Setores na Produção - 1990 -1999.

\begin{tabular}{lrrrrrrrrrrr}
\hline Macro Setores & 1990 & 1991 & 1992 & 1993 & 1994 & 1995 & 1996 & 1997 & 1998 & 1999 & Média \\
\hline Agropecuária & 6,59 & 6,69 & 7,47 & 7,23 & 7,14 & 6,70 & 6,86 & 6,59 & 6,64 & 7,37 & 6,93 \\
Extrativa Mineral (exceto combustíveis) & 0,65 & 0,57 & 0,56 & 0,64 & 0,69 & 0,69 & 0,71 & 0,71 & 0,68 & 0,53 & 0,64 \\
Extração Petróleo,Gás Natural, Carvão e & & & & & & & & & & & \\
Outros Combustíveis. & 0,61 & 0,60 & 0,64 & 0,66 & 0,75 & 0,72 & 0,72 & 0,77 & 1,16 & 0,81 & 0,74 \\
Indústria & 37,06 & 36,44 & 34,68 & 33,90 & 37,99 & 35,71 & 36,37 & 35,76 & 33,95 & 33,79 & 35,56 \\
Serviços Industriais Utilidade Pública & 2,35 & 2,85 & 2,78 & 2,68 & 2,73 & 2,44 & 2,43 & 2,54 & 3,00 & 3,12 & 2,69 \\
Construção Civil & 10,78 & 10,34 & 9,41 & 9,24 & 9,60 & 8,32 & 8,19 & 8,55 & 8,58 & 8,24 & 9,12 \\
Serviços & 41,96 & 42,52 & 44,44 & 45,64 & 48,24 & 45,43 & 44,73 & 45,08 & 45,99 & 46,14 & 45,02 \\
TOTAL & 100 & 100 & 100 & 100 & 100 & 100 & 100 & 100 & 100 & 100 & 100 \\
\hline
\end{tabular}

Fonte: Dados da pesquisa. 


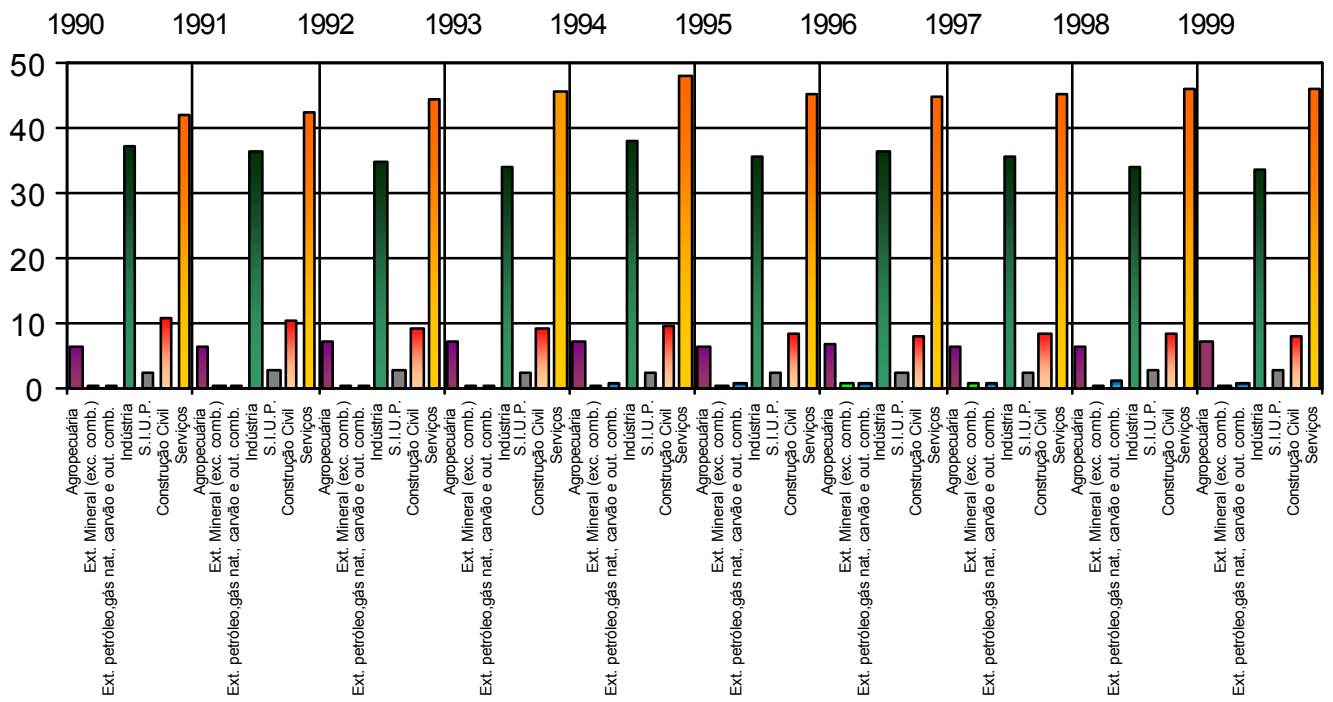

Figura 2 - Participação dos macro setores na produção.

De acordo com a definição do IBGE, o valor da produção de um determinado setor corresponde à soma do seu consumo intermediário, acrescido das remunerações pagas aos trabalhadores do setor, do excedente operacional bruto e dos impostos líquidos sobre a produção.

A produção efetivamente realizada pela economia ou por um setor específico não é representada adequadamente pelo valor da produção, pois a incorporação do consumo intermediário causa o problema da dupla contagem.

O valor da produção, sem duplicações, é dado pelo valor adicionado bruto a preço básico que é constituído pelo custo dos fatores de produção acrescido dos impostos líquidos. Dito de outro modo, diminuindo-se os impostos sobre a atividade do valor adicionado a preço básico, obtém-se o valor adicionado a custo de fatores, que representa mais fielmente o montante de recursos na economia.

A análise dos dados mostrou que os setores Extração de petróleo, gás natural, carvão e outros combustíveis e Serviços industriais de utilidade pública aumentaram sua participação no valor adicionado a custo de fatores. O setor Indústria 
reduziu sua participação relativa, enquanto os outros setores praticamente não a alteraram (tabela 3 e figura 3).

Tabela 3. Participação dos macro setores no valor adicionado (custo de fatores) - 1990 - 1999.

\begin{tabular}{|c|c|c|c|c|c|c|c|c|c|c|c|}
\hline Macro Setores & 1990 & 1991 & 1992 & 1993 & 1994 & 1995 & 1996 & 1997 & 1998 & 1999 & Média \\
\hline Agropecuária & 7,20 & 7,23 & 7,63 & 7,36 & 7,42 & 7,54 & 7,59 & 7,31 & 7,40 & 7,81 & 7,45 \\
\hline Extrativa mineral (exceto combustíveis) & 0,54 & 0,54 & 0,52 & 0,51 & 0,51 & 0,52 & 0,52 & 0,52 & 0,47 & 0,44 & 0,51 \\
\hline Ext. petróleo, gás natural, carvão e outros comb. & 0,80 & 0,76 & 0,76 & 0,74 & 0,76 & 0,76 & 0,83 & 0,86 & 0,87 & 1,03 & 0,82 \\
\hline Indústria & 21,53 & 21,53 & 20,87 & 21,76 & 22,16 & 22,08 & 21,75 & 21,80 & 20,71 & 20,30 & 21,45 \\
\hline Serviços industriais de utilidade pública & 2,17 & 2,30 & 2,31 & 2,34 & 2,33 & 2,45 & 2,53 & 2,60 & 3,10 & 3,20 & 2,53 \\
\hline Construção civil & 9,44 & 9,24 & 8,71 & 8,79 & 8,98 & 8,74 & 8,97 & 9,37 & 9,48 & 9,00 & 9,07 \\
\hline Serviços & 58,33 & 58,40 & 59,21 & 58,50 & 57,85 & 57,90 & 57,81 & 57,54 & 57,97 & 58,21 & 58,17 \\
\hline TOTAL & 100 & 100 & 100 & 100 & 100 & 100 & 100 & 100 & 100 & 100 & 100 \\
\hline
\end{tabular}

Fonte: Dados da pesquisa.

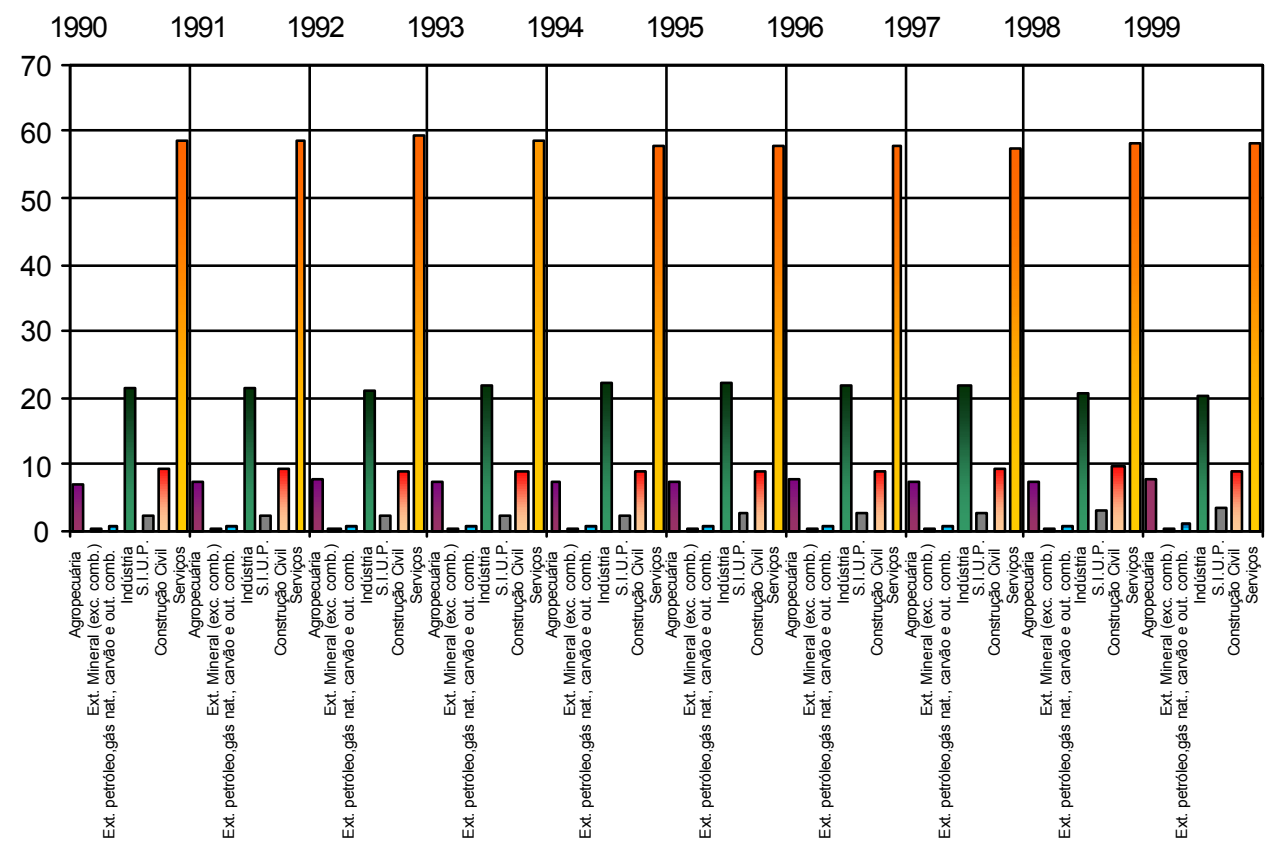

Figura 3 - Participação dos macro setores no valor adicionado a custo de fatores.

No que se refere ao total de postos de trabalho ofertados, mostra que o setor Serviços aumentou significativamente sua participação relativa, passando de $51 \%$ para 58\%. Excetuando o setor de Extração de petróleo, gás natural, carvão e outros 
combustíveis, que permaneceu praticamente constante no período, os demais setores reduziram suas participações relativas na oferta de emprego ${ }^{2}$ (tabela 4 e figura 4).

Tabela 4. Participação dos macro setores no emprego - 1990 - 1999.

\begin{tabular}{lrrrrrrrrrrrr}
\hline Macro setores & 1990 & 1991 & 1992 & 1993 & 1994 & 1995 & 1996 & 1997 & 1998 & 1999 & Média \\
\hline Agropecuária & 25,45 & 25,86 & 26,40 & 26,11 & 25,44 & 24,77 & 23,27 & 22,75 & 21,88 & 23,01 & 24,49 \\
Extrativa mineral (exceto combustíveis) & 0,51 & 0,47 & 0,44 & 0,45 & 0,41 & 0,38 & 0,35 & 0,34 & 0,34 & 0,30 & 0,40 \\
Ext. petróleo, gás natural, carvão e outros comb. & 0,06 & 0,06 & 0,06 & 0,05 & 0,05 & 0,05 & 0,04 & 0,04 & 0,04 & 0,06 & 0,05 \\
Indústria & 15,52 & 14,63 & 13,92 & 13,86 & 13,78 & 13,54 & 13,38 & 12,98 & 12,56 & 12,24 & 13,64 \\
Serviços Industriais de Utilidade Pública & 0,55 & 0,52 & 0,49 & 0,53 & 0,47 & 0,42 & 0,39 & 0,39 & 0,39 & 0,35 & 0,45 \\
Construção Civil & 6,72 & 6,24 & 5,82 & 5,95 & 5,77 & 5,60 & 5,89 & 6,16 & 6,64 & 6,26 & 6,10 \\
Serviços & 51,19 & 52,22 & 52,87 & 53,05 & 54,08 & 55,25 & 56,68 & 57,34 & 58,15 & 57,78 & 54,87 \\
TOTAL & 100 & 100 & 100 & 100 & 100 & 100 & 100 & 100 & 100 & 100 & 100 \\
\hline
\end{tabular}

Fonte: Dados da pesquisa.

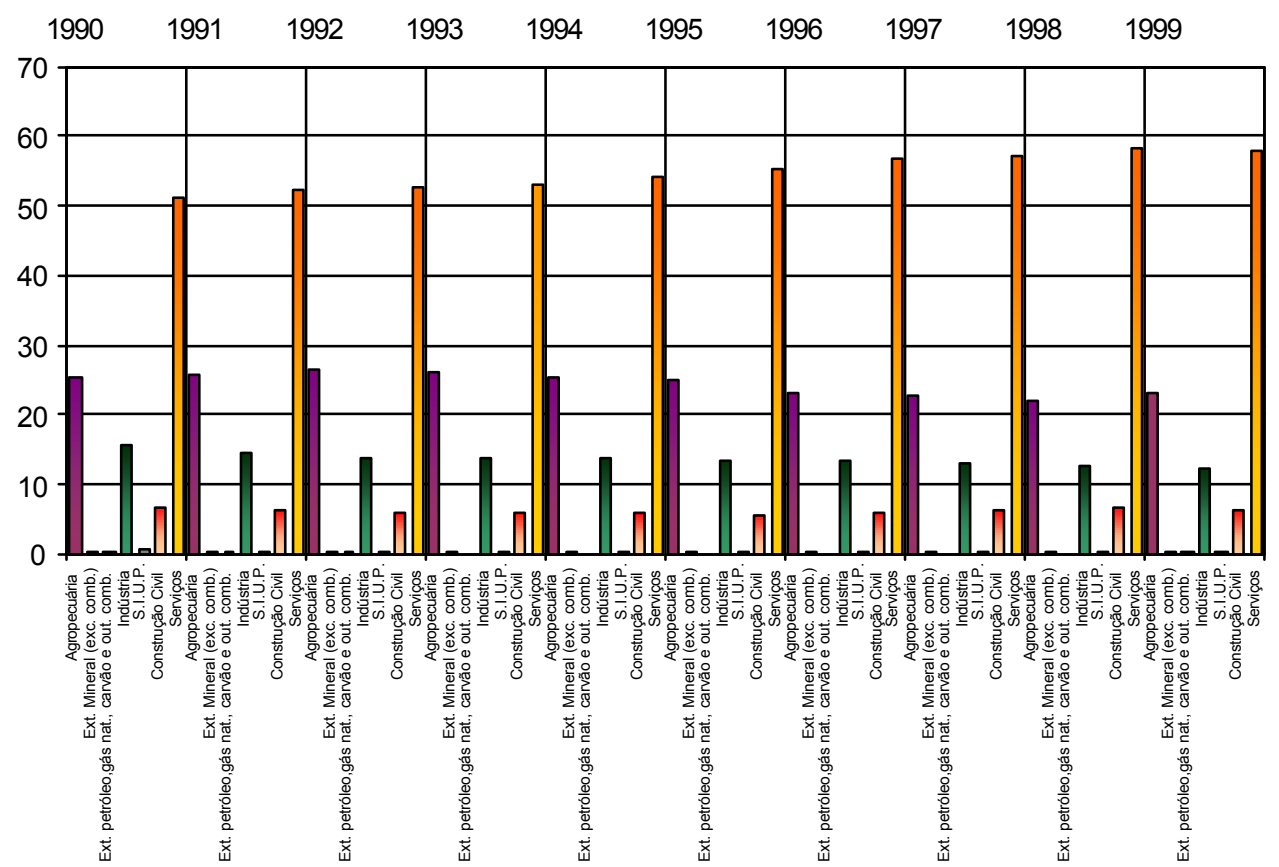

Figura 4 - Participação dos macro setores no emprego - 1990 - 1999.

${ }^{2}$ Este fenômeno observado no Brasil na década de 1990 segue a tendência mundial de terciarização,ou seja, de aumento da importância relativa do setor Serviços (ou setor terciário). Para maiores detalhes, ver Cuadrado-Roura (1999) e Cardoso (2001). 
O índice de turbulência ${ }^{3}$ (tabela 5 e figura 5) ilustra a dinâmica da participação dos macro setores no emprego (tabela 4). Pode-se observar que o setor Indústria apresentou um dos maiores índices de turbulência. Note-se, conforme apontado na seção 3, que neste período houve um ajuste na maneira de produzir de muitas empresas. Embora em menor intensidade, o setor Agropecuária também mostra alguma movimentação no emprego do setor.

Também de acordo com a literatura, o setor Serviços apresentou o maior índice de turbulência no período. Conforme demonstrado, este setor aumentou a oferta de novas oportunidades de trabalho, consolidando-se como grande absorvedor de mãode-obra liberada tanto pelo setor industrial quanto pelo agropecuário.

Tabela 5. Índice de turbulência - $1990-1999$.

\begin{tabular}{|c|c|c|c|c|c|c|c|c|c|c|}
\hline Macro Setores & $91 / 90$ & $92 / 91$ & $93 / 92$ & $94 / 93$ & $95 / 94$ & $96 / 95$ & $97 / 96$ & $98 / 97$ & $99 / 98$ & $99 / 90$ \\
\hline Agropecuária & 0,00205 & 0,00267 & 0,00143 & 0,00339 & 0,00335 & 0,00749 & 0,00258 & 0,00438 & 0,00568 & 0,01222 \\
\hline Extrativa Mineral (exceto combustíveis) & 0,00021 & 0,00015 & 0,00005 & 0,00021 & 0,00016 & 0,00015 & 0,00002 & 0,00000 & 0,00019 & 0,00105 \\
\hline \multicolumn{11}{|c|}{ Extração Petróleo,Gás Natural, Carvão e Outros } \\
\hline Combustíveis. & 0,00001 & 0,00001 & 0,00003 & 0,00000 & 0,00000 & 0,00003 & 0,00001 & 0,00002 & 0,00007 & 0,00001 \\
\hline Indústria & 0,00443 & 0,00355 & 0,00031 & 0,00037 & 0,00121 & 0,00083 & 0,00197 & 0,00213 & 0,00157 & 0,01637 \\
\hline Serviços Industriais de Utilidade Pública & 0,00017 & 0,00015 & 0,00019 & 0,00030 & 0,00026 & 0,00014 & 0,00000 & 0,00001 & 0,00023 & 0,00104 \\
\hline Construção Civil & 0,00241 & 0,00206 & 0,00065 & 0,00093 & 0,00083 & 0,00147 & 0,00130 & 0,00243 & 0,00190 & 0,00228 \\
\hline Serviços & 0,00518 & 0,00325 & 0,00089 & 0,00519 & 0,00582 & 0,00718 & 0,00328 & 0,00405 & 0,00186 & 0,03296 \\
\hline
\end{tabular}

Fonte: Dados da pesquisa.

\footnotetext{
${ }^{3}$ No caso dos macro setores Indústria e Serviços, o índice de turbulência representa a média aritmética dos índices dos setores que os compõem (Anexo A).
} 


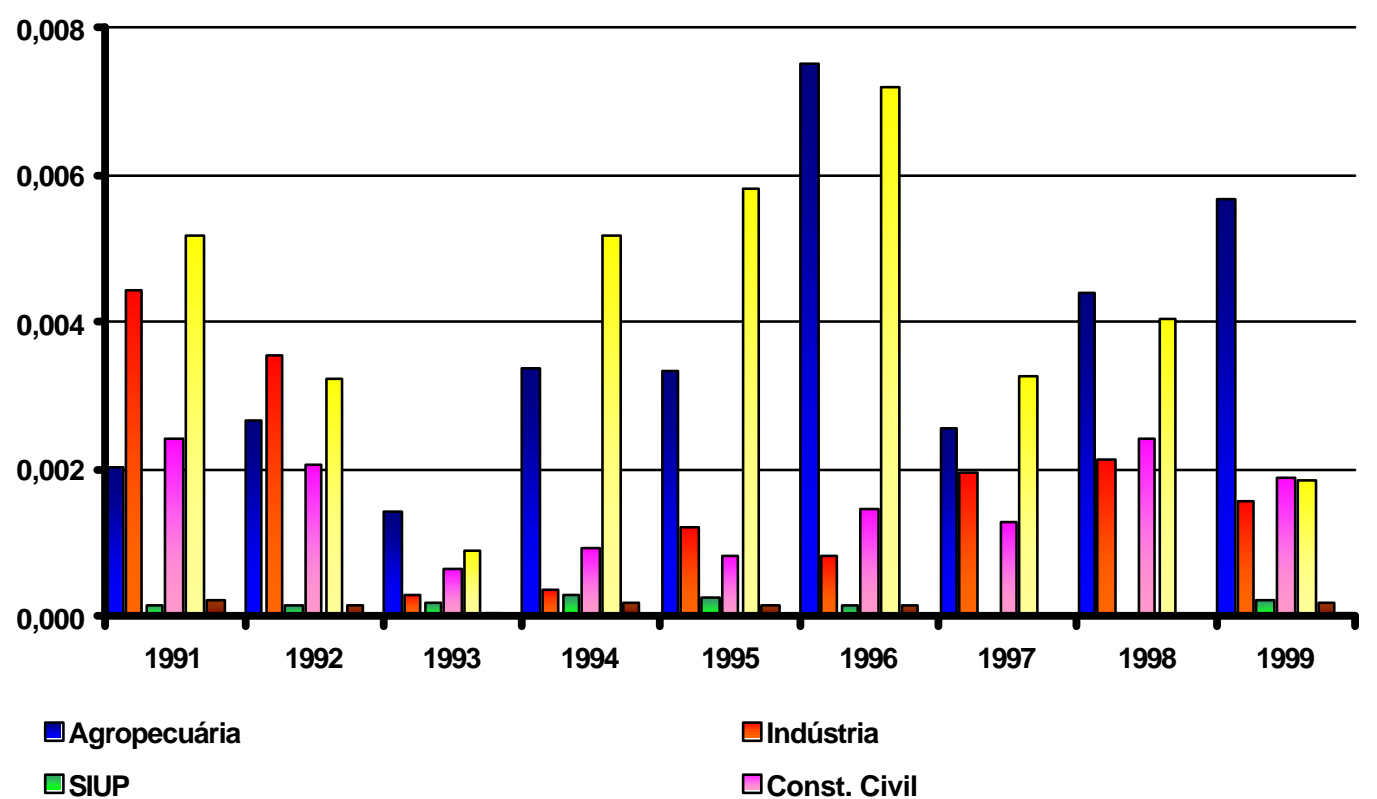

$\square$ Serviços

$\square$ Ext. mineral, exc. Comb.

Ext. petróleo, gás nat., carvão e outros comb.

Figura 5 - Índice de turbulência para os macro setores.

Os multiplicadores de produção do tipo I e do tipo II são mostrados nas tabelas 6 e $7^{4}$. Ambos apresentam um decréscimo em todos os setores no período de 1990 a 1999.

Para o multiplicador do tipo I a média dos 31 setores analisados apresenta uma queda de 2,2 para 1,8. No setor Agropecuária vai de 2,0 para 1,7; no setor Extrativa mineral (exceto combustíveis) diminui de 2,3 para 1,8; Extração de petróleo, gás natural, carvão e outros combustíveis passa de 1,7 para 1,4; Indústria cai de 2,6 para 2,0; o setor Serviços industriais de utilidade pública e o setor Construção civil apresentaram,

\footnotetext{
${ }^{4}$ Todos os multiplicadores calculados no texto para os macro setores Indústria e Serviços correspondem a média aritmética dos multiplicadores dos setores que os compõem.
} 
respectivamente, queda de 2,1 para 1,6 e 2,4 para 1,7 ; e, no setor Serviços o multiplicador passa de 1,6 para 1,4.

Os resultados obtidos para o multiplicador do tipo II mostram que o setor Agropecuária decresce de 3,4 para 3,1; o setor Extrativa mineral (exceto combustíveis) passa de 4,6 para 3,2; Extração de petróleo, gás natural, carvão e outros combustíveis vai de 3,0 para 2,8; Indústria cai de 4,6 para 3,4; Serviços industriais de utilidade pública passa de 4,6 para 3,1; Construção civil reduz de 4,4 para 3,0; e o setor Serviços de 4,4 para 3,4 .

Tabela 6. Multiplicadores de Produção do Tipo I - 1990 - 1999.

\begin{tabular}{lccccccccccc}
\hline Macro Setores & 1990 & 1991 & 1992 & 1993 & 1994 & 1995 & 1996 & 1997 & 1998 & 1999 & Média \\
\hline Agropecuária & 2,00 & 1,98 & 2,03 & 1,96 & 1,83 & 1,62 & 1,67 & 1,65 & 1,64 & 1,73 & 1,81 \\
Extrativa Mineral (exceto combustíveis) & 2,29 & 2,09 & 2,09 & 2,17 & 2,20 & 1,97 & 2,04 & 1,93 & 1,94 & 1,84 & 1,62 \\
Extração Petróleo,Gás Natural, Carvão e Outros & & & & & & & & & \\
Combustíveis. & 1,70 & 1,71 & 1,77 & 1,79 & 1,83 & 1,67 & 1,60 & 1,57 & 1,83 & 1,45 & 1,69 \\
Indústria & 2,60 & 2,56 & 2,53 & 2,40 & 2,43 & 2,05 & 2,09 & 2,01 & 2,00 & 2,04 & 2,27 \\
Serviços Industriais de Utilidade Pública & 2,10 & 2,21 & 2,15 & 2,07 & 2,00 & 1,58 & 1,56 & 1,63 & 1,61 & 1,64 & 1,85 \\
Construção Civil & 2,37 & 2,28 & 2,22 & 2,12 & 2,04 & 1,62 & 1,60 & 1,64 & 1,63 & 1,68 & 1,92 \\
Serviços & 1,61 & 1,60 & 1,59 & 1,59 & 1,60 & 1,39 & 1,41 & 1,42 & 1,43 & 1,47 & 1,51 \\
Média & 2,23 & 2,20 & 2,18 & 2,10 & 2,11 & 1,80 & 1,83 & 1,78 & 1,79 & 1,82 & 1,98 \\
\hline
\end{tabular}

Fonte: Dados da pesquisa.

Tabela 7. Multiplicadores de Produção do Tipo II - 1990 - 1999.

\begin{tabular}{lccccccccccc}
\hline Macro Setores & 1990 & 1991 & 1992 & 1993 & 1994 & 1995 & 1996 & 1997 & 1998 & 1999 & Média \\
\hline Agropecuária & 3,39 & 3,76 & 3,54 & 3,20 & 3,36 & 2,89 & 3,17 & 3,17 & 3,03 & 3,16 & 3,27 \\
Extrativa Mineral (exceto combustíveis) & 4,59 & 4,44 & 4,01 & 3,88 & 4,33 & 3,41 & 3,72 & 3,53 & 3,44 & 3,24 & 3,86 \\
Extração Petróleo,Gás Natural, Carvão e Outros & & & & & & & & & \\
Combustíveis. & 3,01 & 3,51 & 3,32 & 3,09 & 3,67 & 3,03 & 3,13 & 3,06 & 3,29 & 2,84 & 3,20 \\
Indústria & 4,63 & 4,90 & 4,48 & 4,42 & 4,42 & 3,35 & 3,60 & 3,48 & 3,39 & 3,38 & 4,00 \\
Serviços Industriais de Utilidade Pública & 4,63 & 4,89 & 4,55 & 4,46 & 4,71 & 3,10 & 3,25 & 3,41 & 3,17 & 3,15 & 3,93 \\
Construção Civil & 4,39 & 4,55 & 4,07 & 3,57 & 3,80 & 2,82 & 3,01 & 3,09 & 2,98 & 3,04 & 3,53 \\
Serviços & 4,39 & 4,56 & 4,18 & 3,79 & 4,33 & 3,13 & 3,38 & 3,41 & 3,33 & 3,36 & 3,79 \\
Média & 4,46 & 4,69 & 4,30 & 3,86 & 4,32 & 3,24 & 3,48 & 3,42 & 3,34 & 3,33 & 3,84 \\
\hline
\end{tabular}

Fonte: Dados da pesquisa. 
O comportamento dos multiplicadores pode ser observado por meio de gráficos conhecidos como eletroeconogramas ${ }^{5}$, que mostram as diferenças nos valores absolutos dos multiplicadores em relação a um ano base (neste caso, 1990) no intuito de captar diferenças de padrões ao longo do tempo.

Os eletroeconogramas para os multiplicadores do tipo I e tipo II (figuras 6 e 7) indicam uma alteração da estrutura da economia, notadamente a partir de 1994. De um lado, pode-se inferir que houve um aumento na importância dos insumos importados utilizados no processo produtivo e, de outro, pode ter ocorrido intensificação no processo de verticalização da produção.

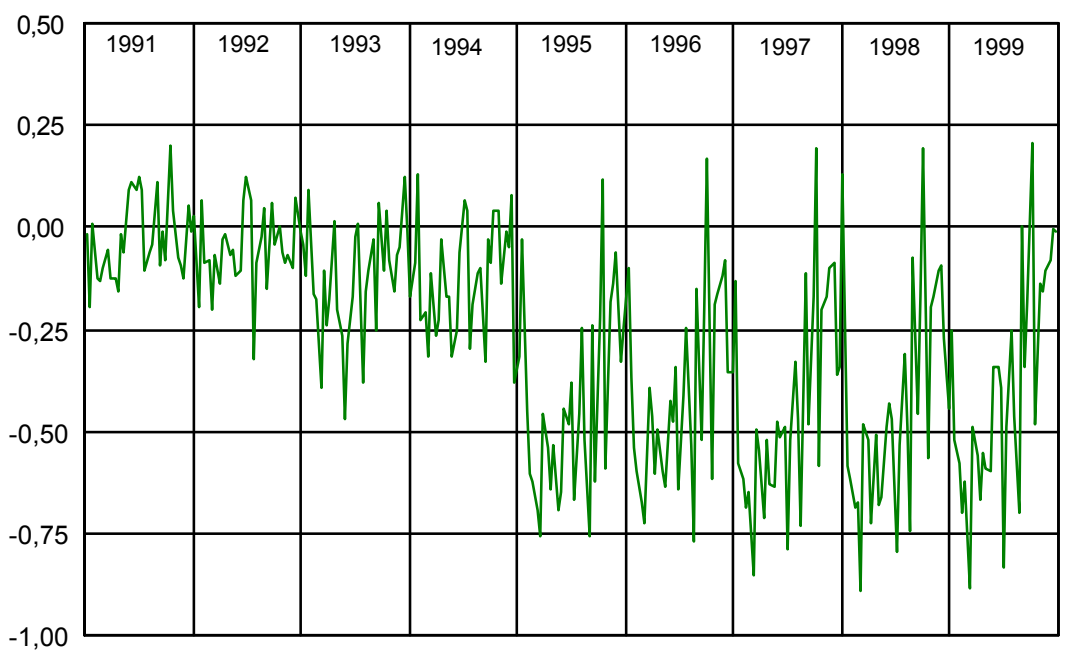

Figura 6 - Eletroeconograma dos multiplicadores de produção do tipo I.

${ }^{5}$ Este conceito foi introduzido por Guilhoto et al. (2001), baseado na idéia dos eletroencefalogramas e eletrocardiogramas na medicina que medem as diferenças em relação a um dado padrão. Quanto maior a amplitude das ondas, mais diferentes serão as estruturas produtivas. 


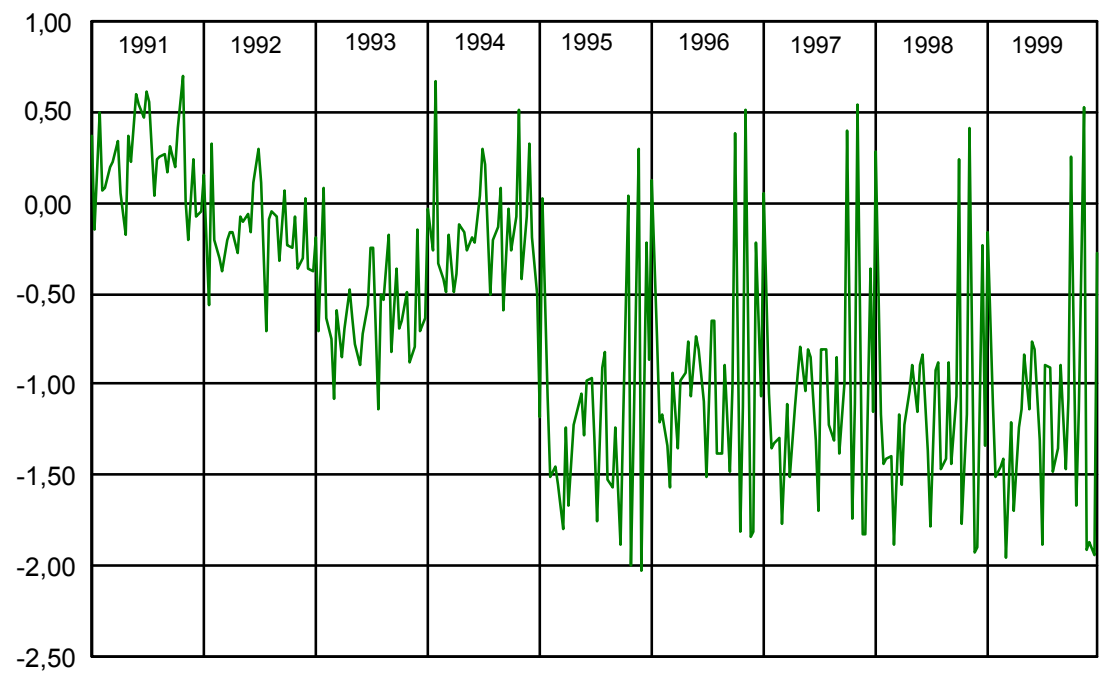

Figura 7 - Eletroeconograma dos multiplicadores de produção do tipo II.

Os índices de ligação de Rasmussen-Hirschman são apresentados nas tabelas 8 e $9^{6}$. Nas ligações para trás, os valores médios para a década de 1990 dos setores Agropecuária, Extrativa mineral (exceto combustíveis); Extração de petróleo, gás natural, carvão e outros combustíveis mantém-se constantes. O setor Indústria é o que apresenta o maior poder de dispersão. O setor Construção Civil apresenta uma redução consecutiva entre os anos de 1990 a 1996 diminuindo a inter-relação com outros setores. O setor Serviços apresentou crescimento contínuo durante todo o período analisado.

As ligações para frente demonstram que os setores Agropecuária, Indústria e Serviços industriais de utilidade pública apresentaram os maiores valores médios no período, indicando que estes setores possuem maior sensibilidade de dispersão. Os setores Construção civil e Serviços apresentaram aumento, embora modesto, na sua importância enquanto fornecedores de insumos ao longo dos anos de

\footnotetext{
${ }^{6}$ Média aritmética dos índices no caso dos macro setores Indústria e Serviços.
} 
1990. O setor Extração de petróleo, gás natural, carvão e outros combustíveis apresentou uma diminuição de importância como fornecedor de insumos na economia.

Tabela 8. Índices de ligação para trás - Hasmussen-Hirschman - 1990 - 1999.

\begin{tabular}{lccccccccccc}
\hline Macro Setores & 1990 & 1991 & 1992 & 1993 & 1994 & 1995 & 1996 & 1997 & 1998 & 1999 & Média \\
\hline Agropecuária & 0,88 & 0,90 & 0,93 & 0,93 & 0,87 & 0,90 & 0,92 & 0,92 & 0,91 & 0,95 & 0,91 \\
Extrativa Mineral (exceto & 1,02 & 0,95 & 0,96 & 1,03 & 1,04 & 1,10 & 1,12 & 1,08 & 1,08 & 1,01 & 1,04 \\
combustíveis) & & & & & & & & & & & \\
Extração Petróleo,Gás Natural, & & & & & & & & & & & \\
Carvão e Outros Combustíveis, & 0,76 & 0,78 & 0,81 & 0,85 & 0,87 & 0,93 & 0,87 & 0,88 & 1,02 & 0,80 & 0,86 \\
Indústria & 1,16 & 1,16 & 1,16 & 1,14 & 1,14 & 1,14 & 1,14 & 1,12 & 1,12 & 1,12 & 1,14 \\
Serviços Industriais de Utilidade & 0,94 & 1,00 & 0,98 & 0,98 & 0,95 & 0,88 & 0,86 & 0,91 & 0,90 & 0,90 & 0,93 \\
Pública & & & & & & & & & & & \\
Construção Civil & 1,06 & 1,03 & 1,02 & 1,00 & 0,97 & 0,90 & 0,88 & 0,92 & 0,91 & 0,92 & 0,96 \\
Serviços & 0,72 & 0,73 & 0,73 & 0,75 & 0,76 & 0,77 & 0,77 & 0,80 & 0,80 & 0,81 & 0,76 \\
\hline
\end{tabular}

Fonte: Dados da pesquisa.

Tabela 9. Índices de ligação para frente - Hasmussen-Hirschman - 1990 - 1999.

\begin{tabular}{lrrrrrrrrrrr}
\hline Macro Setores & 1990 & 1991 & 1992 & 1993 & 1994 & 1995 & 1996 & 1997 & 1998 & 1999 & Média \\
\hline Agropecuária & 1,56 & 1,56 & 1,57 & 1,58 & 1,74 & 1,61 & 1,63 & 1,56 & 1,60 & 1,51 & 1,59 \\
Extrativa Mineral (exceto combustíveis) & 0,73 & 0,70 & 0,70 & 0,72 & 0,72 & 0,75 & 0,74 & 0,74 & 0,73 & 0,72 & 0,72 \\
Extração Petróleo, Gás Natural, Carvão e Outros & & & & & & & & & & \\
Combustíveis. & 1,23 & 1,25 & 1,16 & 0,98 & 1,01 & 0,79 & 0,85 & 0,85 & 0,77 & 0,99 & 0,99 \\
& 1,11 & 1,11 & 1,10 & 1,10 & 1,09 & 1,04 & 1,02 & 1,00 & 0,99 & 1,00 & 1,06 \\
Indústria & 1,31 & 1,43 & 1,49 & 1,48 & 1,47 & 1,28 & 1,30 & 1,31 & 1,45 & 1,44 & 1,40 \\
Serviços Industriais de Utilidade Pública & 0,59 & 0,57 & 0,57 & 0,60 & 0,61 & 0,69 & 0,67 & 0,68 & 0,68 & 0,67 & 0,63 \\
Construção Civil & 0,75 & 0,74 & 0,74 & 0,75 & 0,77 & 0,92 & 0,94 & 0,99 & 1,00 & 0,96 & 0,85 \\
Serviços & & & & & & & & & & &
\end{tabular}

Fonte: Dados da pesquisa.

Os índices puros de ligação (normalizados) são apresentados nas tabelas 10 a 12 e mostram a importância dos setores na composição dos valores da produção na economia ${ }^{7}$. Os setores Agropecuária, Serviços industriais de utilidade pública e Serviços apresentaram crescimento em relação aos outros setores no período.

Observando-se os índices puros normalizados para trás e para frente, pode-se verificar que o setor Agropecuária aumentou sua importância na economia em ambos os indicadores; Extração de petróleo, gás natural, carvão e outros combustíveis

\footnotetext{
${ }^{7}$ Média aritmética dos setores para Indústria e Serviços.
} 
apresentaram valores negativos ${ }^{8}$ nas ligações para trás que são compensados pelos valores nas ligações para frente; Extrativa mineral (exceto combustíveis) e Indústria aumentam seus valores nas ligações para trás que são compensadas pela diminuição nos valores das ligações para frente. $O$ setor da Construção civil apresentou uma queda significativa nas ligações para trás que não são compensadas nas ligações para frente indicando que o setor perde participação na economia.

Tabela 10. Índice de ligação puro normalizado para trás - 1990 - 1999.

\begin{tabular}{lccccccccccc}
\hline Macro Setores & 1990 & 1991 & 1992 & 1993 & 1994 & 1995 & 1996 & 1997 & 1998 & 1999 & Média \\
\hline Agropecuária & 0,91 & 0,89 & 0,90 & 0,72 & 0,87 & 1,00 & 0,98 & 0,99 & 1,02 & 1,28 & 0,96 \\
Extrativa Mineral (exceto combustíveis) & 0,11 & 0,17 & 0,19 & 0,13 & 0,11 & 0,18 & 0,19 & 0,17 & 0,18 & 0,18 & 0,16 \\
Extração Petróleo,Gás Natural, Carvão e Outros & & & & & & & & & & \\
Combustíveis. & $(0,32)$ & $(0,, 32)$ & $(0,32)$ & $(0,26)$ & $(0,28)$ & 0,00 & 0,001 & 0,00 & 0,00 & 0,00 & $(0,15)$ \\
Indústria & 0,52 & 0,53 & 0,53 & 0,53 & 0,56 & 0,77 & 0,78 & 0,75 & 0,71 & 0,71 & 0,64 \\
Serviços Industriais de Utilidade Pública & 0,26 & 0,38 & 0,41 & 0,25 & 0,21 & 0,18 & 0,19 & 0,20 & 0,22 & 0,23 & 0,25 \\
Construção Civil & 6,56 & 5,95 & 5,63 & 5,43 & 5,49 & 3,96 & 4,00 & 4,50 & 4,50 & 4,28 & 5,03 \\
Serviços & 1,62 & 1,66 & 1,68 & 1,74 & 1,68 & 1,39 & 1,37 & 1,39 & 1,44 & 1,44 & 1,54 \\
\hline
\end{tabular}

Fonte: Dados da pesquisa.

Tabela 11. Índice de ligação puro normalizado para frente - 1990 - 1999.

\begin{tabular}{lccccccccccc}
\hline Macro Setores & 1990 & 1991 & 1992 & 1993 & 1994 & 1995 & 1996 & 1997 & 1998 & 1999 & Média \\
\hline Agropecuária & 2,89 & 3,09 & 3,11 & 3,22 & 3,71 & 3,80 & 3,89 & 3,65 & 3,71 & 3,47 & 3,45 \\
Extrativa Mineral (exceto combustíveis) & 0,35 & 0,32 & 0,31 & 0,30 & 0,30 & 0,26 & 0,25 & 0,24 & 0,23 & 0,23 & 0,28 \\
Extração Petróleo,Gás Natural, Carvão e Outros & & & & & & & & & & & \\
Combustíveis. & 1,02 & 0,97 & 0,92 & 0,70 & 0,68 & 0,36 & 0,44 & 0,43 & 0,34 & 0,72 & 0,66 \\
Indústria & 1,12 & 1,10 & 1,08 & 1,08 & 1,06 & 0,89 & 0,87 & 0,85 & 0,83 & 0,86 & 0,98 \\
Serviços Industriais de Utilidade Pública & 1,29 & 1,57 & 1,66 & 1,46 & 1,46 & 1,33 & 1,34 & 1,30 & 1,58 & 1,57 & 1,45 \\
Construção Civil & 0,34 & 0,34 & 0,33 & 0,34 & 0,37 & 0,47 & 0,45 & 0,45 & 0,46 & 0,43 & 0,40 \\
Serviços & 0,71 & 0,71 & 0,73 & 0,77 & 0,75 & 1,13 & 1,15 & 1,20 & 1,22 & 1,15 & 0,95 \\
\hline
\end{tabular}

Fonte: Dados da pesquisa.

Tabela 12. Índice de ligação puro total normalizado - 1990 - 1999.

\begin{tabular}{lccccccccccc}
\hline Macro Setores & 1990 & 1991 & 1992 & 1993 & 1994 & 1995 & 1996 & 1997 & 1998 & 1999 & Média \\
\hline Agropecuária & 1,90 & 1,98 & 2,00 & 1,96 & 2,28 & 2,40 & 2,43 & 2,32 & 2,36 & 2,37 & 8,80 \\
Extrativa Mineral (exceto combustíveis) & 0,23 & 0,25 & 0,25 & 0,22 & 0,21 & 0,22 & 0,22 & 0,20 & 0,20 & 0,20 & 1,02 \\
Extração Petróleo,Gás Natural, Carvão e Outros & & & & & & & & & & & \\
Combustíveis. & 0,35 & 0,32 & 0,30 & 0,22 & 0,20 & 0,18 & 0,22 & 0,22 & 0,17 & 0,36 & 1,18 \\
Indústria & 0,82 & 0,81 & 0,81 & 0,81 & 0,81 & 0,83 & 0,82 & 0,80 & 0,77 & 0,79 & 0,81 \\
Serviços Industriais de Utilidade Pública & 0,77 & 0,97 & 1,03 & 0,85 & 0,83 & 0,75 & 0,76 & 0,75 & 0,90 & 0,90 & 0,85 \\
Construção Civil & 3,47 & 3,16 & 3,00 & 2,90 & 2,94 & 2,22 & 2,23 & 2,48 & 2,48 & 2,36 & 2,72 \\
Serviços & 1,15 & 1,17 & 1,19 & 1,24 & 1,20 & 1,24 & 1,23 & 1,27 & 1,31 & 1,27 & 1,23 \\
\hline
\end{tabular}

Fonte: Dados da pesquisa.

\footnotetext{
${ }^{8}$ Os valores negativos são devido aos subsídios do governo ao setor.
} 
A evolução das inter-relações da economia brasileira pode ser vista por intermédio de um gráfico tridimensional, conforme proposto por Guilhoto, MarjottaMaistro e Hewings (2002). Esta análise capta as alterações na estrutura produtiva mostrando a topografia econômica (landscape) da economia brasileira em anos selecionados (figuras 8 e 9).

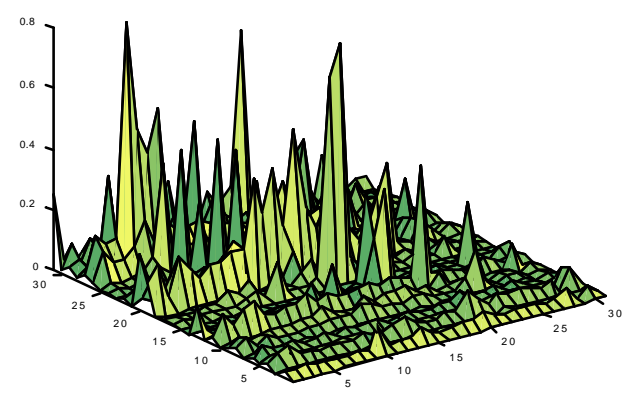

1990

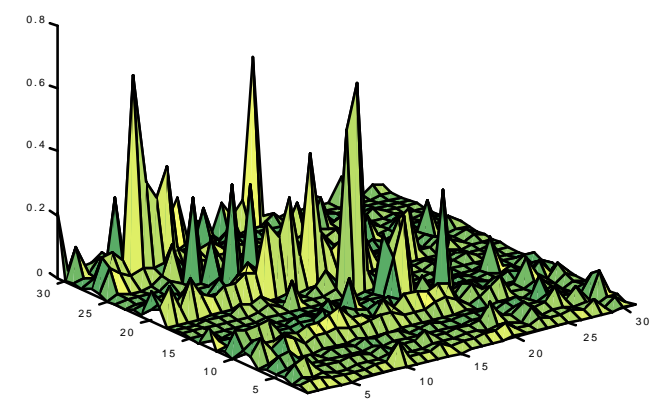

1995

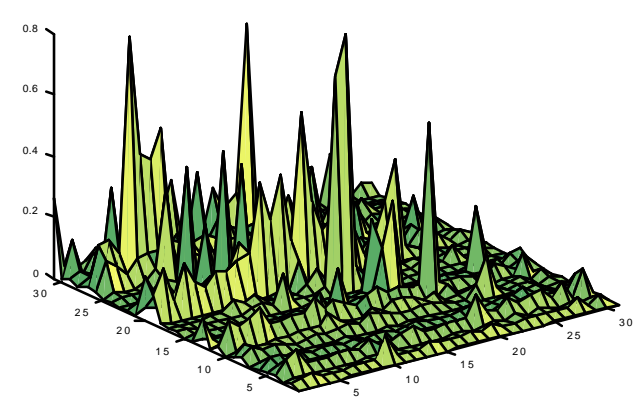

1994

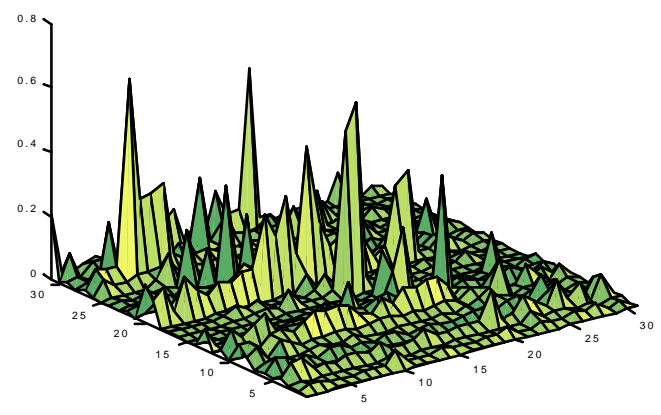

1999

Figura 8 - Topografia econômica da economia brasileira em anos selecionados. 


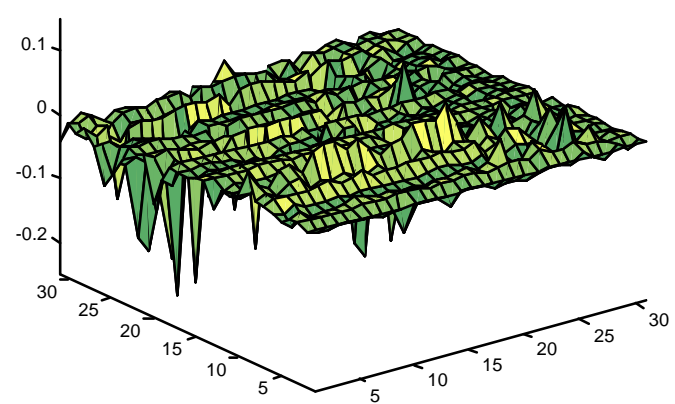

1999 menos 1990

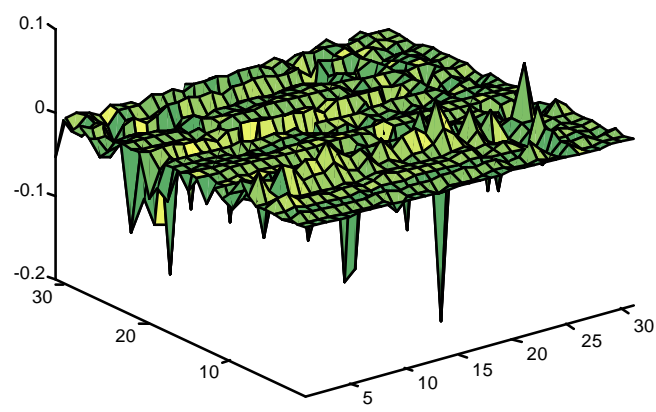

1995 menos 1994

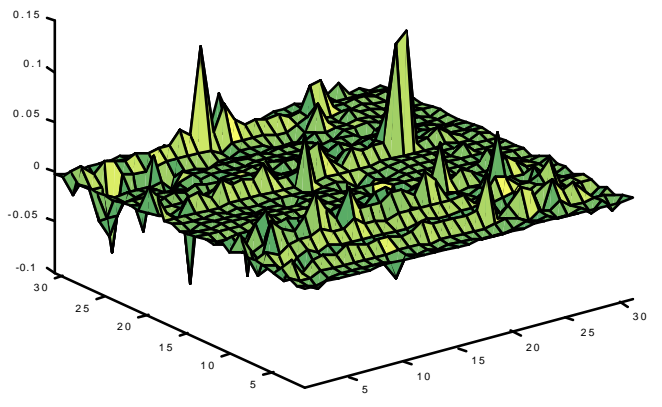

1999 menos 1994

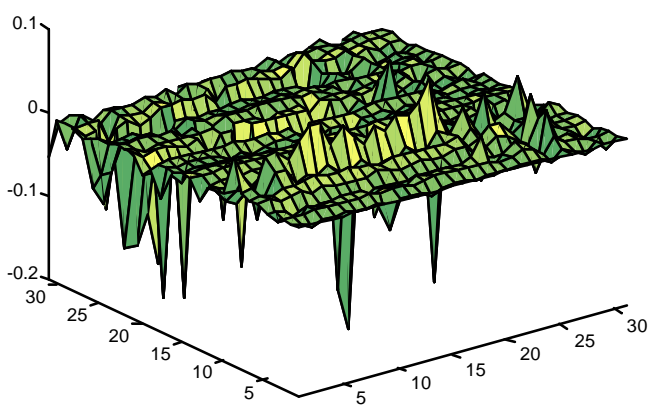

1999 menos 1995

Figura 9 - Diferença entre as topografias econômicas da economia brasileira em anos selecionados.

A figura 8 mostra que a topografia econômica da economia é similar para os anos de 1990, 1994, 1995 e 1999. No entanto, a figura 9, que mostra as diferenças entre anos selecionados, mostra que a economia passou por mudanças e que, a maioria delas, se deram na primeira metade da década. 
A análise da capacidade de geração de empregos dos macros setores está relacionada à estrutura produtiva da economia e fazem parte do conjunto de tabelas 13 a 15.

Nas tabelas 13 e 14 é possível observar que os multiplicadores de emprego do tipo I diminuem, excetuando-se o aumento apresentado pelo setor Extração de petróleo, gás natural, carvão e outros combustíveis. Os multiplicadores do tipo II só apresentaram queda nos setores Extrativa Mineral e Construção civil.

Tabela 13. Multiplicador de emprego do tipo I - 1990 - 1999.

\begin{tabular}{|c|c|c|c|c|c|c|c|c|c|c|c|}
\hline MACRO SETORES & 1990 & 1991 & 1992 & 1993 & 1994 & 1995 & 1996 & 1997 & 1998 & 1999 & Média \\
\hline Agropecuária & 1,33 & 1,33 & 1,35 & 1,34 & 1,32 & 1,27 & 1,29 & 1,28 & 1,29 & 1,30 & 1,31 \\
\hline Extrativa Mineral (exceto combustíveis) & 2,00 & 1,82 & 1,81 & 1,93 & 2,07 & 2,10 & 2,33 & 2,27 & 1,96 & 2,02 & 2,02 \\
\hline \multicolumn{12}{|c|}{ Extração Petróleo,Gás Natural, Carvão e Outros } \\
\hline Combustíveis. & 5,98 & 6,16 & 6,80 & 7,53 & 8,16 & 7,57 & 7,85 & 8,68 & 11,67 & 7,54 & 7,54 \\
\hline Indústria & 5,04 & 5,43 & 4,73 & 4,09 & 4,66 & 4,00 & 4,27 & 4,28 & 4,35 & 4,52 & 4,52 \\
\hline Serviços Industriais de Utilidade Pública & 3,35 & 4,54 & 4,24 & 3,04 & 3,02 & 2,31 & 2,37 & 2,56 & 2,85 & 3,13 & 3,13 \\
\hline Construção Civil & 2,35 & 2,29 & 2,11 & 1,97 & 1,94 & 1,65 & 1,58 & 1,60 & 1,53 & 1,86 & 1,86 \\
\hline Serviços & 1,59 & 1,57 & 1,53 & 1,63 & 1,66 & 1,50 & 1,51 & 1,54 & 1,63 & 1,58 & 1,58 \\
\hline Média & 3,71 & 3,95 & 3,57 & 3,23 & 3,57 & 3,11 & 3,28 & 3,32 & 3,48 & 3,45 & 3,45 \\
\hline
\end{tabular}

Fonte: Dados da pesquisa.

Tabela 14. Multiplicador de emprego do tipo II - 1990 - 1999.

\begin{tabular}{|c|c|c|c|c|c|c|c|c|c|c|c|}
\hline Macro Setores & 1990 & 1991 & 1992 & 1993 & 1994 & 1995 & 1996 & 1997 & 1998 & 1999 & Média \\
\hline Agropecuária & 1,75 & 1,85 & 1,82 & 1,73 & 1,80 & 1,73 & 1,85 & 1,82 & 1,85 & 1,84 & 1,80 \\
\hline Extrativa Mineral (exceto combustíveis) & 5,40 & 5,01 & 4,45 & 4,66 & 6,09 & 5,58 & 6,72 & 6,38 & 4,76 & 4,77 & 5,38 \\
\hline \multicolumn{12}{|l|}{ Extração Petróleo,Gás Natural, Carvão e Outros } \\
\hline Combustíveis. & 22,08 & 27,80 & 26,56 & 27,25 & 39,16 & 33,61 & 39,48 & 42,84 & 43,21 & 27,39 & 32,94 \\
\hline Indústria & 13,75 & 17,22 & 13,27 & 10,37 & 14,52 & 11,73 & 13,63 & 13,41 & 13,53 & 13,82 & 13,53 \\
\hline Serviços Industriais de Utilidade Pública & 15,87 & 21,17 & 19,03 & 16,77 & 20,69 & 14,22 & 15,77 & 16,85 & 17,75 & 19,12 & 17,72 \\
\hline Construção Civil & 6,13 & 6,54 & 5,36 & 4,52 & 5,20 & 4,03 & 4,06 & 4,08 & 3,54 & 3,69 & 4,71 \\
\hline Serviços & 5,66 & 7,02 & 6,05 & 5,52 & 7,76 & 6,89 & 7,56 & 7,72 & 7,94 & 7,98 & 7,01 \\
\hline Média & 10,84 & 13,49 & 10,88 & 9,06 & 12,57 & 10,34 & 11,86 & 11,91 & 12,02 & 11,73 & 11,47 \\
\hline
\end{tabular}

Fonte: Dados da pesquisa. 
A capacidade de geração de empregos por $\mathrm{R} \$ 1$ milhão foi reduzida em média, na década de 1999 em 57 empregos (tabela 15), indicando que neste período a economia foi muito mais intensiva em capital do que em trabalho.

Desta forma, observa-se que embora os multiplicadores apresentados pelo setor Agropecuária e pelo setor Serviços tenham sido os mais baixos, são estes setores os que possuem maior capacidade de geração de empregos por R 1 milhão investido.Uma das possíveis explicações é que, nestes setores, os salários são, em geral, menores. Além disto, eles são muito mais intensivos em trabalho, confirmando a análise demonstrada na tabela 4.

Tabela 15. Emprego total gerado por R\$ 1 milhão de 1999 - 1990 - 1999.

\begin{tabular}{lccccccccccccccc}
\hline Macro Setores & 1990 & 1991 & 1992 & 1993 & 1994 & 1995 & 1996 & 1997 & 1998 & 1999 & Média \\
\hline Agropecuária & 271,77 & 292,65 & 269,91 & 257,83 & 275,08 & 256,14 & 237,47 & 232,60 & 196,10 & 210,23 & 249,98 \\
Extrativa Mineral (exceto combustíveis) & 171,24 & 170,47 & 147,53 & 135,79 & 154,86 & 122,85 & 122,98 & 113,00 & 108,54 & 99,48 & 134,67 \\
& & & & & & & & & & \\
Extração Petróleo,Gás Natural, Carvão e Outros & & & & & & & & \\
Combustíveis. & 83,95 & 106,95 & 95,53 & 83,85 & 111,76 & 93,48 & 91,73 & 85,73 & 85,58 & 73,78 & 91,23 \\
Indústria & 169,30 & 182,70 & 161,24 & 139,86 & 164,30 & 129,74 & 128,73 & 121,39 & 109,56 & 108,05 & 141,49 \\
Serviços Industriais de Utilidade Pública & 150,16 & 157,76 & 141,10 & 136,43 & 152,68 & 97,37 & 95,08 & 95,36 & 79,39 & 77,43 & 118,28 \\
Construção Civil & 153,49 & 161,37 & 139,45 & 119,93 & 134,38 & 108,83 & 110,45 & 108,59 & 101,66 & 102,57 & 124,07 \\
Serviços & 231,72 & 243,70 & 223,09 & 205,44 & 235,36 & 194,59 & 195,96 & 191,83 & 179,37 & 182,35 & 208,34 \\
Média & 186,91 & 199,62 & 178,79 & 160,02 & 185,17 & 149,53 & 148,70 & 142,75 & 130,59 & 130,37 & 161,24 \\
\hline
\end{tabular}

Fonte: Dados da pesquisa.

Decompondo a geração total de empregos em empregos diretos, indiretos e induzidos (tabelas 16 a 18) verifica-se que, em média, os setores Agropecuária e Serviços mantiveram a capacidade de gerar o maior número de empregos diretos. Os empregos indiretos foram gerados em grande parte pela Agropecuária, seguida pelo setor Indústria.

Durante todo o período, os empregos induzidos concentraram-se no setor Serviços, seguido pelo setor Serviços industriais de utilidade pública. 
Tabela 16. Empregos diretos gerados por R \$ 1 milhão de 1999 - 1990 - 1999.

\begin{tabular}{|c|c|c|c|c|c|c|c|c|c|c|c|}
\hline Macro Setores & 1990 & 1991 & 1992 & 1993 & 1994 & 1995 & 1996 & 1997 & 1998 & 1999 & Média \\
\hline Agropecuária & 155,18 & 158,17 & 148,44 & 148,74 & 153,00 & 148,23 & 128,25 & 127,70 & 105,77 & 114,28 & 138,78 \\
\hline Extrativa Mineral (exceto combustíveis) & 31,74 & 34,04 & 33,15 & 29,16 & 25,42 & 22,01 & 18,29 & 17,70 & 22,83 & 20,84 & 25,52 \\
\hline \multicolumn{12}{|c|}{ Extração Petróleo,Gás Natural, Carvão e Outros } \\
\hline Combustíveis. & 3,80 & 3,85 & 3,60 & 3,08 & 2,85 & 2,78 & 2,32 & 2,00 & 1,98 & 2,69 & 2,90 \\
\hline Indústria & 28,17 & 29,21 & 29,54 & 28,64 & 27,91 & 27,50 & 25,67 & 25,12 & 22,99 & 23,39 & 26,81 \\
\hline Serviços Industriais de Utilidade Pública & 9,46 & 7,45 & 7,41 & 8,13 & 7,38 & 6,85 & 6,03 & 5,66 & 4,47 & 4,05 & 6,69 \\
\hline Construção Civil & 25,03 & 24,67 & 26,01 & 26,54 & 25,82 & 27,02 & 27,21 & 26,63 & 28,73 & 27,82 & 26,55 \\
\hline Serviços & 83,86 & 88,72 & 88,13 & 85,93 & 86,33 & 88,25 & 88,78 & 88,27 & 85,85 & 87,92 & 87,20 \\
\hline Média & 47,06 & 49,13 & 48,84 & 47,61 & 47,29 & 47,37 & 45,73 & 45,20 & 42,81 & 43,83 & 46,49 \\
\hline
\end{tabular}

Fonte: Dados da pesquisa.

Tabela 17. Empregos indiretos gerados por R\$ 1 milhão de 1999 - 1990 - 1999.

\begin{tabular}{lccccccccccc}
\hline Macro Setores & 1990 & 1991 & 1992 & 1993 & 1994 & 1995 & 1996 & 1997 & 1998 & 1999 & Média \\
\hline Agropecuária & 51,24 & 52,29 & 52,35 & 51,14 & 48,62 & 39,66 & 37,24 & 35,45 & 30,88 & 34,01 & 43,29 \\
Extrativa Mineral (exceto combustíveis) & 31,82 & 27,82 & 26,69 & 27,09 & 27,08 & 24,24 & 24,41 & 22,43 & 21,96 & 18,17 & 25,17 \\
Extração Petróleo,Gás Natural, Carvão e Outros & & & & & & & & & & \\
Combustíveis. & 18,95 & 19,87 & 20,86 & 20,11 & 20,43 & 18,26 & 15,92 & 15,38 & 21,13 & 10,75 & 18,17 \\
Indústria & 45,87 & 45,28 & 42,51 & 38,43 & 40,62 & 32,65 & 30,70 & 29,09 & 27,17 & 26,89 & 35,92 \\
Serviços Industriais de Utilidade Pública & 22,22 & 26,39 & 24,02 & 16,64 & 14,87 & 8,99 & 8,28 & 8,82 & 8,26 & 7,98 & 14,65 \\
Construção Civil & 33,89 & 31,74 & 29,00 & 25,81 & 24,15 & 17,52 & 15,89 & 15,95 & 15,13 & 15,68 & 22,48 \\
Serviços & 17,95 & 18,27 & 16,92 & 16,64 & 17,38 & 13,21 & 12,86 & 12,87 & 12,23 & 12,71 & 15,11 \\
Média & 35,47 & 35,24 & 33,16 & 30,45 & 31,68 & 25,24 & 23,85 & 22,85 & 21,59 & 21,23 & 28,08 \\
\hline
\end{tabular}

Fonte: Dados da pesquisa.

Tabela 18. Empregos induzidos gerados por R\$ 1 milhão de 1999 - 1990 - 1999.

\begin{tabular}{|c|c|c|c|c|c|c|c|c|c|c|c|}
\hline Macro Setores & 1990 & 1991 & 1992 & 1993 & 1994 & 1995 & 1996 & 1997 & 1998 & 1999 & Média \\
\hline Agropecuária & 65,35 & 82,19 & 69,12 & 57,95 & 73,45 & 68,24 & 71,98 & 69,45 & 59,46 & 61,93 & 67,91 \\
\hline Extrativa Mineral (exceto combustíveis) & 107,68 & 108,60 & 87,69 & 79,54 & 102,36 & 76,60 & 80,28 & 72,86 & 63,75 & 60,47 & 83,98 \\
\hline \multicolumn{12}{|c|}{ Extração Petróleo,Gás Natural, Carvão e Outros } \\
\hline Combustíveis. & 61,20 & 83,23 & 71,07 & 60,66 & 88,48 & 72,44 & 73,48 & 68,35 & 62,47 & 60,33 & 70,17 \\
\hline Indústria & 95,26 & 108,22 & 89,19 & 72,79 & 95,78 & 69,59 & 72,36 & 67,18 & 59,40 & 57,77 & 78,75 \\
\hline Serviços Industriais de Utilidade Pública & 118,48 & 123,91 & 109,67 & 111,66 & 130,43 & 81,53 & 80,78 & 80,89 & 66,65 & 65,40 & 96,94 \\
\hline Construção Civil & 94,56 & 104,96 & 84,44 & 67,58 & 84,41 & 64,28 & 67,35 & 66,01 & 57,79 & 59,07 & 75,05 \\
\hline Serviços & 129,91 & 136,70 & 118,03 & 102,87 & 131,66 & 93,13 & 94,32 & 90,68 & 81,30 & 81,72 & 106,03 \\
\hline Média & 104,39 & 115,25 & 96,79 & 81,96 & 106,20 & 76,91 & 79,13 & 74,70 & 66,18 & 65,32 & 86,68 \\
\hline
\end{tabular}

Fonte: Dados da pesquisa.

O comportamento da geração de empregos pode ser ilustrado por meio dos eletroeconogramas (figura 10). 


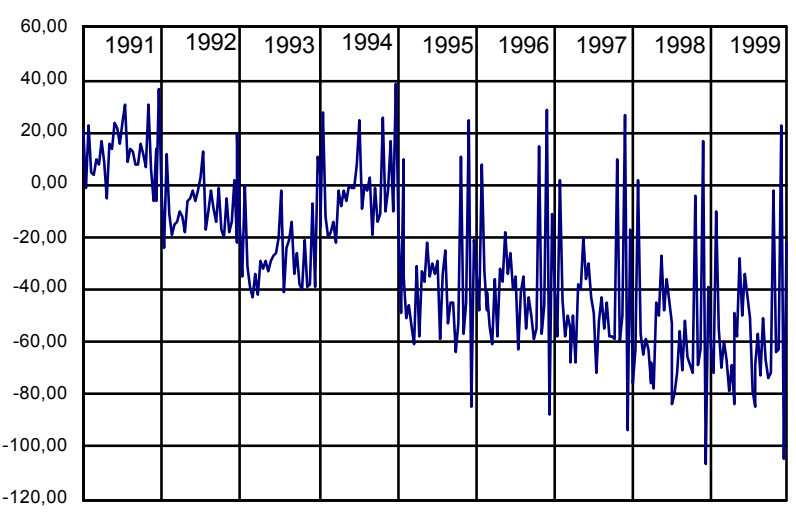

Geração total de empregos

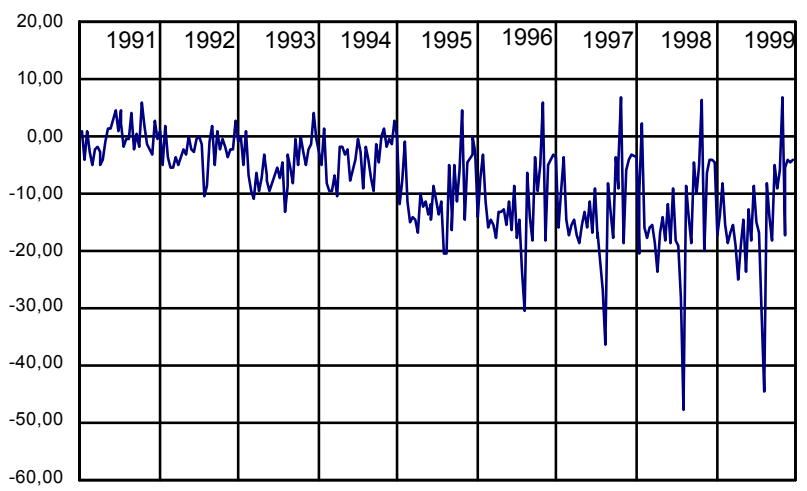

Geração de empregos indiretos

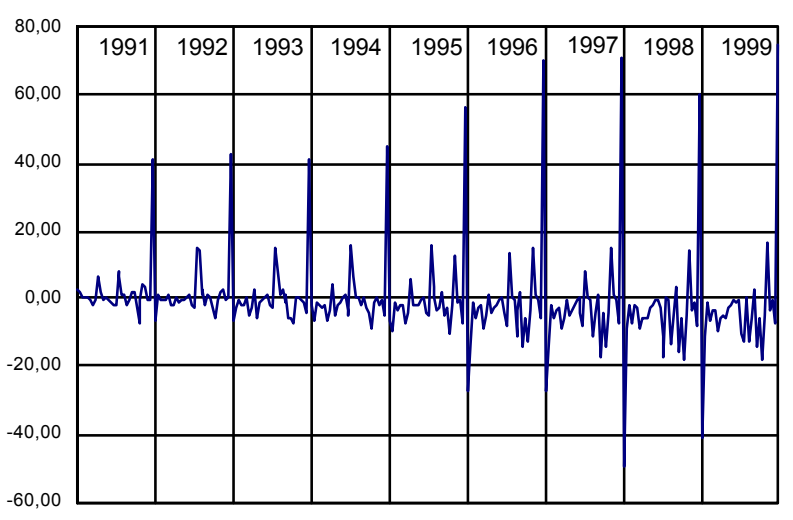

Geração de empregos diretos

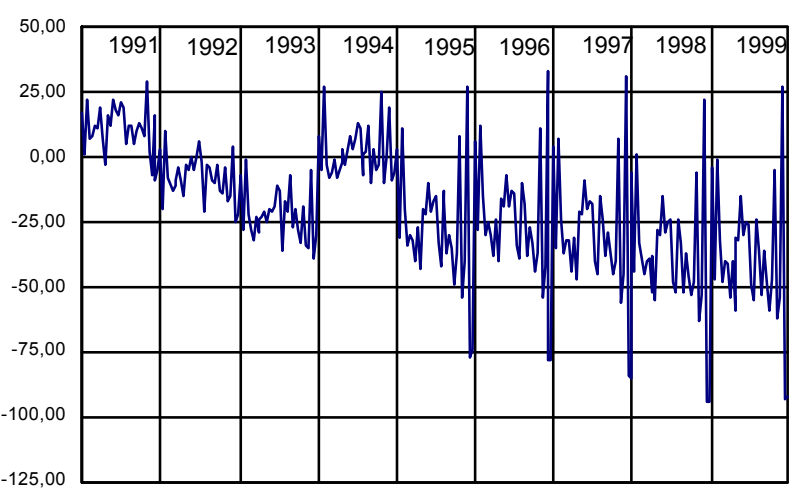

Geração de empregos induzidos

Figura 10 - Eletroeconogramas da geração de emprego. 
A figura 11 indica que, com exceção do ano de 1994, há uma tendência consistente de diminuição da oferta de postos de trabalho em todos os setores, embora este fenômeno apresente intensidades diferentes por categoria de emprego (empregos diretos, indiretos e induzidos).

O comportamento discrepante de 1994 parece ser explicado pelo efeito da estabilização do nível de preços sobre a renda das famílias. Com maior poder aquisitivo, elas aumentaram o consumo e, por conseqüência, a produção de todos os setores da economia, o que, por sua vez, levou a um aumento no emprego.

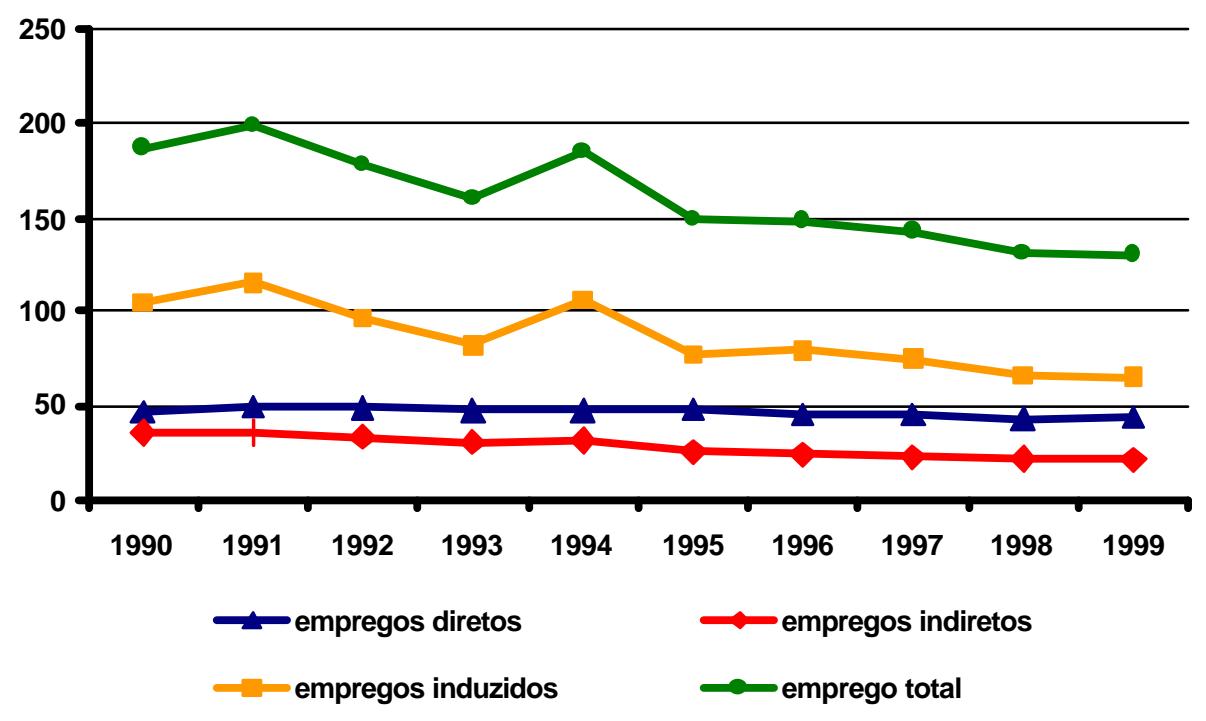

Figura 11 - Oferta de postos de trabalho por categoria no Brasil - 1990 - 1999.

\subsection{Efeitos da abertura comercial sobre o mercado de trabalho}

Esta seção analisa os efeitos da abertura comercial sobre o emprego na década de 1990.

As tabelas 19 a 22 mostram o efeito da balança comercial sobre o valor adicionado e emprego. Esta análise parte da hipótese de que todos os produtos importados poderiam ser produzidos internamente. Deste modo, assim como as 
exportações contribuem positivamente, as importações afetam direta e negativamente a produção, o valor adicionado e a geração de postos de trabalho.

O efeito da balança comercial sobre o valor adicionado (tabela 19 e figura 12), passou a ser negativo a partir de 1995 mantendo-se assim até 1999. Isto pode ser atribuído a mudança no comportamento das exportações e importações, indicando que a economia neste período exportou produtos mais intensivos em trabalho e importou produtos intensivos em capital.

Tabela 19. Impacto da balança comercial sobre o valor adicionado (R\$ milhões de 1999) 1990 - 1999.

\begin{tabular}{|c|c|c|c|c|c|c|c|c|c|c|}
\hline Macro Setores & 1990 & 1991 & 1992 & 1993 & 1994 & 1995 & 1996 & 1997 & 1998 & 1999 \\
\hline Agropecuária & 6.338 .527 & 4.398 .548 & 6.003 .770 & 6.065 .021 & 6.508 .140 & 2.720 .132 & 2.812 .986 & 2.881 .113 & 2.253 .308 & 3.918 .581 \\
\hline \multicolumn{11}{|l|}{ Extrativa Mineral (exceto } \\
\hline combustíveis) & 2.423 .240 & 2.826 .532 & 2.712 .890 & 2.698 .937 & 2.363 .567 & 1.497 .717 & 1.584 .433 & 1.596 .032 & 1.739 .092 & 1.855 .133 \\
\hline \multicolumn{11}{|l|}{ Extração Petróleo,Gás Natural, } \\
\hline Carvão e Outros Combustíveis. & -4.652 .306 & -5.811 .875 & -4.488 .293 & -4.085 .279 & -4.996 .104 & -5.138 .091 & -5.534 .147 & -5.680 .387 & -4.692 .992 & -4.850 .737 \\
\hline Indústria & 11.080 .426 & 7.432 .171 & 14.654 .972 & 11.429 .499 & 3.061 .756 & -8.332 .653 & -8.074 .837 & -18.683 .975 & -15.741 .027 & -13.683 .387 \\
\hline \multicolumn{11}{|l|}{ Serviços Industriais de Utilidade } \\
\hline Pública & -13.715 & -670.815 & -72.244 & -248.455 & -575.632 & -1.044 .026 & -955.024 & -1.338 .660 & -1.679 .044 & -1.588 .178 \\
\hline Construção Civil & 33.645 & -6.005 & 25.943 & 13.921 & -26.429 & -71.221 & -62.564 & -125.258 & -132.158 & -64.133 \\
\hline Serviços & 1.546 .103 & -1.407 .502 & -92.264 & -1.630 .430 & -2.540 .374 & -2.002 .965 & -2.520 .649 & -6.129 .979 & -8.349 .000 & -5.358 .360 \\
\hline Total & 16.632 .480 & 6.761 .054 & 18.744 .773 & 14.243 .215 & 3.794 .923 & -12.371 .108 & -12.749 .803 & -27.481 .116 & -26.601 .823 & -19.771 .082 \\
\hline
\end{tabular}

Fonte: Dados da pesquisa. 


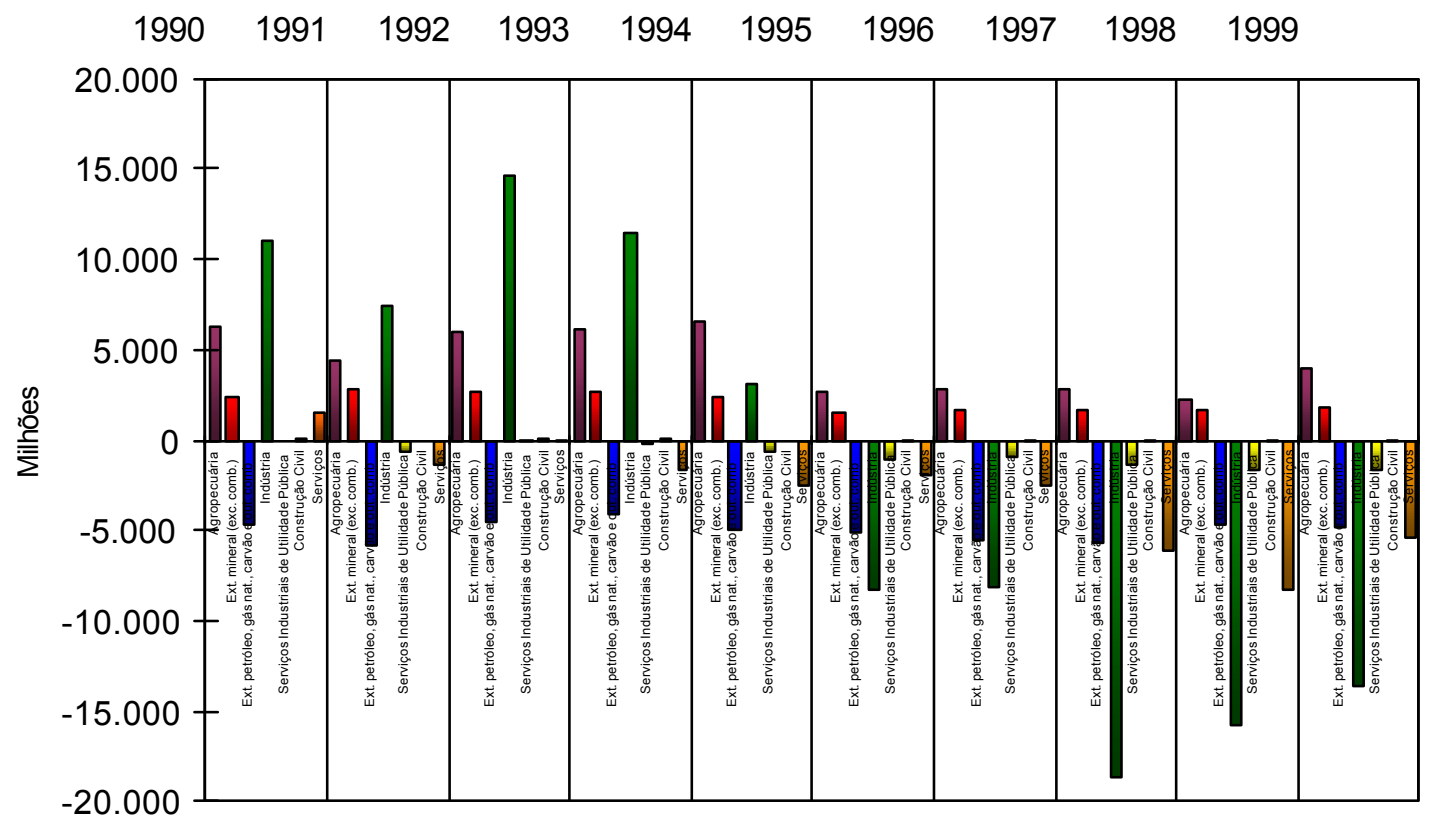

Figura 12 - Impacto da balança comercial sobre o valor adicionado (R milhões de 1999) 1990 - 1999.

A tabela 20 e a figura 13 mostram os resultados do efeito do saldo da balança comercial sobre o emprego. No início da década, quando o saldo era positivo, as exportações líquidas eram responsáveis pela ocupação de aproximadamente $4,5 \%$ do total da mão-de-obra empregada.

A partir de 1995, quando as exportações líquidas tornaram-se negativas, observa-se uma diminuição dos postos de trabalho. Somente no último ano da década, após um forte ajuste na taxa de câmbio, a recuperação das exportações reflete-se também numa melhora da oferta de postos de trabalho. 
Tabela 20. Impacto da balança comercial sobre o emprego (número de pessoas) -

$$
1990-1999 .
$$

\begin{tabular}{|c|c|c|c|c|c|c|c|c|c|c|}
\hline Macro Setores & 1990 & 1991 & 1992 & 1993 & 1994 & 1995 & 1996 & 1997 & 1998 & 1999 \\
\hline Agropecuária & 1.742 .958 & 1.221 .723 & 1.628 .769 & 1.639 .184 & 1.645 .940 & 652.279 & 599.939 & 609.522 & 456.952 & 799.300 \\
\hline $\begin{array}{l}\text { Extrativa Mineral (exceto } \\
\text { combustíveis) }\end{array}$ & 180.513 & 190.024 & 180.926 & 181.813 & 139.857 & 78.674 & 73.898 & 71.540 & 86.486 & 88.920 \\
\hline Extração Petróleo,Gás Natural, & & & & & & & & & & \\
\hline Carvão e Outros Combustíveis. & -26.393 & -33.741 & -25.618 & -20.798 & -24.082 & -24.663 & -20.502 & -18.695 & -16.618 & -19.246 \\
\hline Indústria & 710.178 & 645.328 & 998.316 & 854.520 & 522.213 & 59.460 & 75.173 & -270.258 & -194.017 & 3.637 \\
\hline Serviços Industriais de Utilidad & & & & & & & & & & \\
\hline Pública & -2.726 & -11.797 & -1.205 & -4.280 & -8.563 & -12.985 & -10.196 & -13.601 & -14.548 & -11.847 \\
\hline Construção Civil & 1863 & -315 & 1361 & 719 & -1252 & -3335 & -2861 & -5590 & -6349 & -3091 \\
\hline Serviços & 147.899 & -106.409 & -57.406 & -194.232 & -288.909 & -214.486 & -320.416 & -567.834 & -721.661 & -296.009 \\
\hline Total & 2.754 .295 & 1.904 .814 & 2.725 .144 & 2.456 .926 & 1.985 .206 & 534.944 & 395.035 & -194.917 & -409.755 & 561.665 \\
\hline
\end{tabular}

Fonte: Dados da pesquisa.

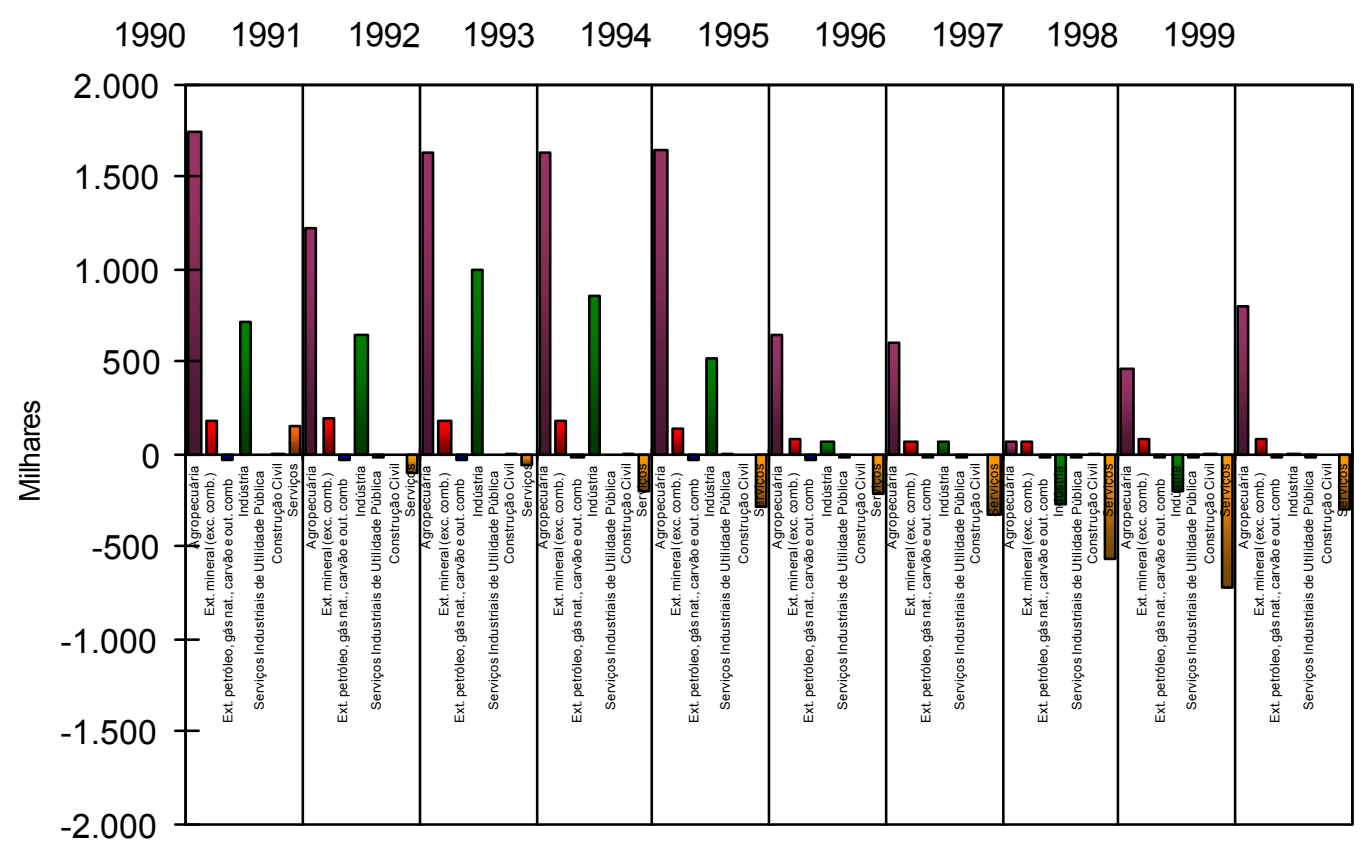

Figura 13 - Impacto da balança comercial sobre o emprego (número de pessoas). 
Pode-se decompor o efeito do saldo da balança comercial sobre o emprego em dois componentes: o efeito positivo das exportações sobre a geração de postos de trabalho e o efeito negativo das importações sobre eles ${ }^{9}$.

A tabela 21 mostra o impacto das exportações sobre a geração de postos de trabalho. A reestruturação produtiva causada pela abertura da economia teve um impacto significativo sobre a geração de empregos ligados à exportação, particularmente na segunda metade da década, quando houve um período de valorização cambial.Somente em 1999, após o ajuste do câmbio, a geração de postos de trabalho voltou aos patamares do início da década

A maior resposta na geração de empregos foi do setor Agropecuária durante toda a década, embora o setor Serviços nos dois últimos anos analisados apresentou valores superiores quando comparado ao setor Agropecuária (figura 14).

Tabela 21. Impacto da exportação sobre o emprego (número de pessoas) - 1990 - 1999.

\begin{tabular}{lccccccccccc}
\hline Macro setores & 1990 & 1991 & 1992 & 1993 & 1994 & 1995 & 1996 & 1997 & 1998 & 1999 \\
\hline Agropecuária & 2.720 .424 & 2.497 .524 & 2.748 .330 & 2.756 .330 & 3.127 .469 & 1.949 .844 & 1.796 .727 & 1.734 .063 & 1.582 .067 & 1.882 .071 \\
Extrativa Mineral (exceto combustíveis) & 227.671 & 238.111 & 224.090 & 223.075 & 184.234 & 112.044 & 102.019 & 101.024 & 113.597 & 12.286 \\
Extração Petróleo,Gás Natural, Carvão e & & & & & & & & & & \\
Outros Combustíveis. & 17.761 & 18.428 & 16.242 & 9.390 & 9.321 & 3.257 & 3.097 & 2.333 & 1.293 & 6.503 \\
Indústria & 1.582 .458 & 1.707 .812 & 1.971 .332 & 1.874 .744 & 1.695 .311 & 1.225 .955 & 1.165 .893 & 917.389 & 967.474 & 1.310 .958 \\
Serviços Industriais de Utilidade Pública & 38.733 & 38.128 & 44.588 & 39.844 & 35.471 & 18.381 & 18.254 & 14.090 & 16.582 & 18.314 \\
Construção Civil & 9.588 & 8.867 & 10.036 & 10.121 & 10.977 & 9.425 & 9.562 & 8.752 & 12.314 & 13.275 \\
Serviços & 1.112 .242 & 1.086 .884 & 1.164 .317 & 1.110 .618 & 1.090 .837 & 1.381 .285 & 1.292 .699 & 1.574 .853 & 1.777 .906 & 2.367 .566 \\
Total & 5.708 .879 & 5.595 .754 & 6.178 .936 & 6.024 .121 & 6.153 .621 & 4.700 .191 & 4.388 .251 & 4.352 .505 & 4.471 .234 & 5.721 .553 \\
\hline
\end{tabular}

Fonte: Dados da pesquisa.

\footnotetext{
${ }^{9}$ Novamente, partindo-se da hipótese que a economia brasileira seria capaz de produzir internamente tudo o que ela importa.
} 


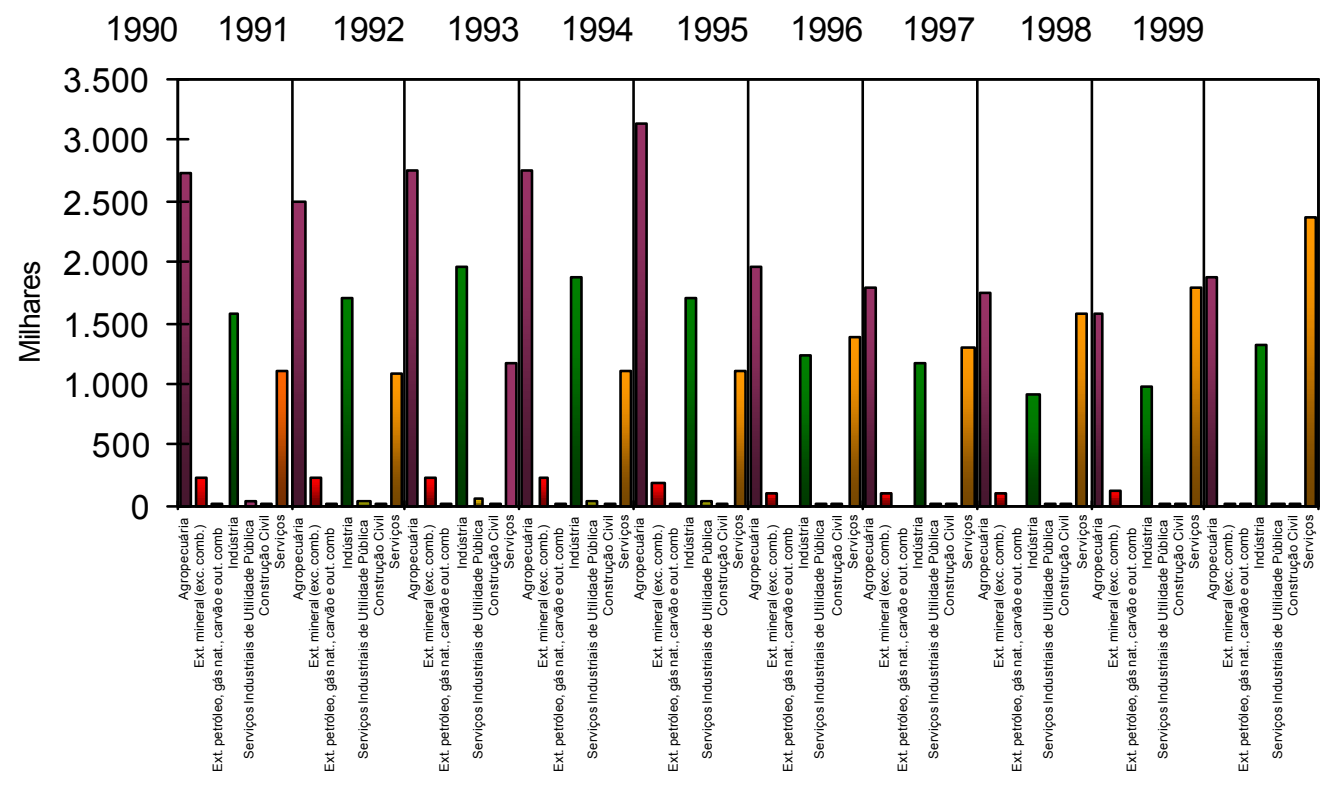

Figura 14 - Impacto da exportação sobre o emprego (número de pessoas) - 1990 - 1999.

A tabela 22 e a figura 15 mostram os postos de trabalho que deixam de ser gerados por conta das importações. Ao longo de toda década este número aumenta. Os setores que mais sentiram este efeito foram o setor Serviços; o setor Indústria; e o setor Agropecuária. Isto é natural, na medida em que os demais setores não são afetados significativamente pelo comércio internacional.

Tabela 22. Impacto da importação sobre o emprego (número de pessoas) - 1990 - 1999.

\begin{tabular}{|c|c|c|c|c|c|c|c|c|c|c|}
\hline Macro setores & 1990 & 1991 & 1992 & 1993 & 1994 & 1995 & 1996 & 1997 & 1998 & 1999 \\
\hline Agropecuária & 977.466 & 1.275 .800 & 1.119 .561 & 1.117 .146 & 1.481 .528 & 1.297 .565 & 1.196 .788 & 1.124 .541 & 1.125 .115 & 1.082 .771 \\
\hline \multicolumn{11}{|l|}{ Extrativa Mineral (exceto } \\
\hline combustíveis) & 47.158 & 48.087 & 43.164 & 41.262 & 44.377 & 33.369 & 28.122 & 29.484 & 27.111 & 33.944 \\
\hline \multicolumn{11}{|l|}{ Extração Petróleo,Gás Natural, Carvão } \\
\hline e Outros Combustíveis. & 44.154 & 52.169 & 41.860 & 30.188 & 33.403 & 27.920 & 23.599 & 21.028 & 17.912 & 25.749 \\
\hline Indústria & 872.279 & 1.062 .484 & 973.017 & 1.020 .224 & 1.173 .098 & 1.166 .495 & 1.090 .720 & 1.187 .647 & 1.161 .491 & 1.307 .321 \\
\hline Serviços Industriais de Utilidade & 41.459 & 499.925 & 45.793 & 44.124 & 44.035 & 31.366 & 28.450 & 27.690 & 31.130 & 30.162 \\
\hline \multicolumn{11}{|l|}{ Pública } \\
\hline Construção Civil & 7.724 & 9.182 & 8.675 & 9.402 & 12.229 & 12.759 & 12.423 & 14.343 & 18.663 & 16.366 \\
\hline Serviços & 964.343 & 1.193 .293 & 1.221 .722 & 1.304 .850 & 1.379 .746 & 1.595 .771 & 1.613 .116 & 2.142 .687 & 2.499 .566 & 2.663 .575 \\
\hline Total & 2.954 .584 & 3.690 .940 & 3.453 .792 & 3.567 .195 & 4.168 .416 & 4.165 .247 & 3.993 .216 & 4.547 .422 & 4.880 .989 & 5.159 .888 \\
\hline
\end{tabular}

Fonte: Dados da pesquisa. 


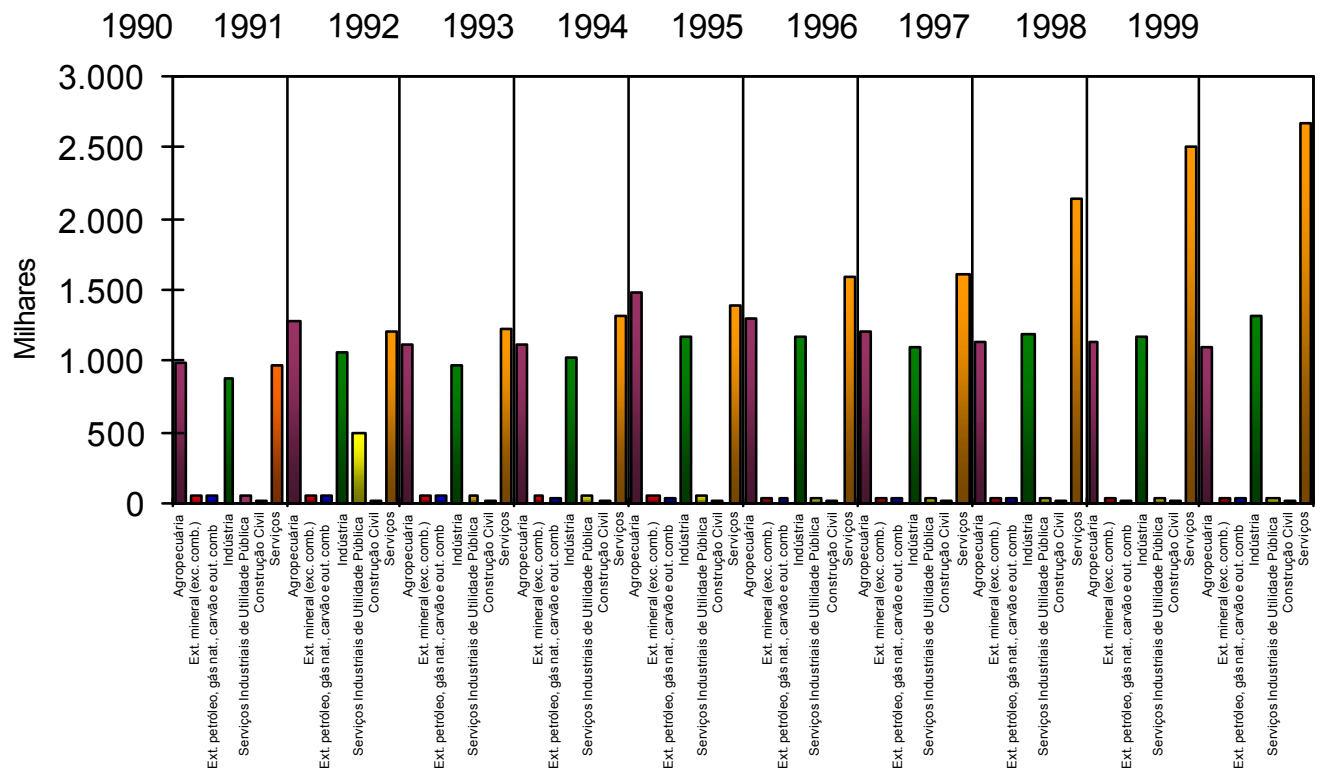

Figura 15 - Impacto da importação sobre o emprego (número de pessoas) - 1990 - 1999.

\section{Conclusões}

Durante os anos noventa a economia brasileira passou por mudanças decorrentes da estabilização do nível de preços e da consolidação do processo de abertura econômica, as quais impactaram a estrutura produtiva e a oferta de postos de trabalho.

As modificações do processo produtivo permitiram que setores como a Agropecuária e Serviços aumentassem suas participações no total produzido.

Em geral, os multiplicadores de produção demonstraram que todos os setores passaram a ser mais dependente de insumos importados.

Neste período, a economia brasileira foi muito mais exportadora de produtos intensivos em trabalho e grande importadora de produtos intensivos em capital, implicando em mudanças na estrutura da oferta de postos de trabalho. 
Além da diminuição dos postos de trabalho, os multiplicadores de emprego mostraram uma queda na capacidade de geração de novos postos de trabalho (empregos diretos, indiretos e induzidos) em toda a economia.

Embora estes indicadores tenham sido negativos para todos os setores, a resposta, em relação a capacidade de geração de postos de trabalho, dos setores Agropecuária e Serviços foi superior aos outros setores durante o período analisado, pois, conforme demonstrado, os primeiros são intensivos em trabalho.

Finalmente, os resultados do impacto da abertura econômica sobre o emprego devem ser vistos com certa cautela em decorrência da hipótese de que a economia brasileira poderia produzir tudo aquilo que ela importa. Neste sentido, trabalhos futuros podem elaborar maneiras de contornar esta pressuposição, obtendo, assim, resultados mais precisos. 
ANEXO A - Setores da matriz insumo-produto.

\begin{tabular}{|c|c|c|}
\hline Setor & Descrição & Macro setor \\
\hline 01 & Agropecuária & 01 \\
\hline 02 & Extrativa mineral (exceto combustíveis) & 02 \\
\hline 03 & Extração de petróleo, gás natural, carvão e outros combustíveis & 03 \\
\hline 04 & Fabricação de minerais não metálicos & 04 \\
\hline 05 & Siderurgia, metais não ferrosos e outros produtos metalúrgicos & 04 \\
\hline 06 & Fabricação e manutenção de máquinas e tratores & 04 \\
\hline 07 & $\begin{array}{l}\text { Fabricação de aparelhos e equipamentos material elétrico e } \\
\text { eletrônico }\end{array}$ & 04 \\
\hline 08 & Fabricação automóveis caminhões ônibus, peças e acessórios & 04 \\
\hline 09 & Serrarias e fabricação de artigos de madeira e mobiliário & 04 \\
\hline 10 & Indústria de papel e gráfica & 04 \\
\hline 11 & Indústria da borracha & 04 \\
\hline 12 & $\begin{array}{l}\text { Fabricação elementos químicos não petroquímicos e químicos } \\
\text { diversos }\end{array}$ & 04 \\
\hline 13 & Refino de petróleo e indústria petroquímica & 04 \\
\hline 14 & Fabricação de produtos farmacêuticos e de perfumaria & 04 \\
\hline 15 & Indústria de transformação de material plástico & 04 \\
\hline 16 & Indústria Têxtil & 04 \\
\hline 17 & Fabricação de artigos do vestuário e acessórios & 04 \\
\hline 18 & Fabricação de calçados e de artigos de couro e peles & 04 \\
\hline 19 & Indústria de alimentos em geral & 04 \\
\hline 20 & Indústrias diversas & 04 \\
\hline 21 & Serviços industriais de utilidade pública (S.I.U.P.) & 05 \\
\hline 22 & Construção civil & 06 \\
\hline 23 & Comércio & 07 \\
\hline 24 & Transporte & 07 \\
\hline 25 & Comunicações & 07 \\
\hline 26 & Instituições Financeiras & 07 \\
\hline 27 & Serviços prestados às famílias & 07 \\
\hline 28 & Serviços prestados às empresas & 07 \\
\hline 29 & Aluguel de imóveis & 07 \\
\hline 30 & Administração Pública & 07 \\
\hline 31 & Serviços privados não mercantis & 07 \\
\hline
\end{tabular}


ANEXO B - Participação relativa dos setores na produção.

\begin{tabular}{|c|c|c|c|c|c|c|c|c|c|c|c|}
\hline & $\mathrm{C}_{3}$ & 1990 & 1991 & 1992 & 1993 & 1994 & 1995 & 1996 & 1997 & 1998 & 1999 \\
\hline 1 & Agropecuúria & 6,59 & 6,69 & 7,47 & 7,23 & 6,67 & 6,70 & 6,86 & 6,59 & 6,64 & 7,37 \\
\hline 2 & Extrativa mineral (exceto combustiveis) & 0,65 & 0,57 & 0,56 & 0,64 & 0,64 & 0,69 & 0,71 & 0,71 & 0,68 & 0,53 \\
\hline 3 & Ext.de petróleo e gás natural, carvão e outros comb. & 0,61 & 0,60 & 0,64 & 0,66 & 0,70 & 0,72 & 0,72 & 0,77 & 1,16 & 0,81 \\
\hline 4 & Fabricacăo de minerais näo-metálicos & 1,41 & 1,31 & 1,30 & 1,31 & 1,23 & 1,26 & 1,32 & 1,31 & 1,22 & 1,26 \\
\hline 5 & Siderurgia, met ñ-ferrosos e out.prod.metalurgicos & 4,69 & 4,26 & 4,39 & 4,54 & 4,71 & 4,45 & 4,60 & 4,64 & 4,52 & 4,15 \\
\hline 6 & Fabricaçăo e manutenç̧ão de máquinas e tratotres & 2,24 & 1,98 & 1,82 & 1,78 & 2,06 & 1,96 & 1,86 & 1,88 & 1,76 & 1,75 \\
\hline 7 & Fab.de ap.e equip.de matelétrtico eletrônico & $\begin{array}{l}2,45 \\
1,45\end{array}$ & 1,38 & 1,19 & 1,37 & 1,63 & 1,79 & 1,87 & 1,80 & 1,63 & 1,60 \\
\hline 8 & Fab.auto.cam.onib.out.veic,., pę̧as e acessórios & 2,26 & 2,15 & 2,15 & 2,44 & 2,56 & 2,57 & 2,62 & 2,77 & 2,41 & 2,53 \\
\hline 9 & Serrarias e fab. de artigos de madeira e mobiliário & 1,11 & 0,93 & 0,99 & 1,00 & 0,95 & 0,92 & 0,98 & 0,96 & 0,92 & 0,96 \\
\hline 10 & Indústria de papel e gráifica & 1,61 & 1,44 & 1,69 & 2,08 & 1,96 & 1,63 & 1,71 & 1,75 & 1,83 & 1,74 \\
\hline 11 & Indústria da borracha & 0,68 & 0,67 & 0,68 & 0,71 & 0,70 & 0,66 & 0,65 & 0,66 & 0,59 & 0,50 \\
\hline 12 & Fab. Elem. quimicos näo-petroq.e quím.diversos & 2,82 & 2,89 & 2,86 & 2,60 & 2,87 & 2,88 & 2,99 & 3,00 & 2,84 & 2,50 \\
\hline 13 & Refino de petróleo e indústria petroquímica & 5,10 & 5,93 & 4,65 & 3,52 & 3,98 & 4,12 & 4,40 & 4,30 & 3,77 & 4,41 \\
\hline 14 & Fab. de produtos farmacêuticos e de perfumaria & 1,05 & 1,28 & 0,98 & 0,93 & 0,90 & 1,01 & 0,96 & 0,93 & 0,95 & 1,06 \\
\hline 15 & Indústria de transformaçăo de material plástico & 0,66 & 0,70 & 0,68 & 0,65 & 0,67 & 0,68 & 0,71 & 0,71 & 0,67 & 0,62 \\
\hline 16 & Indusstria têxtil & 1,30 & 1,37 & 1,37 & 1,30 & 1,37 & 1,23 & 1,16 & 1,09 & 1,13 & 1,25 \\
\hline 17 & Fabricąăa de artigos do vestuário e acessórios & 0,76 & 0,68 & 0,64 & 0,65 & 0,64 & $\begin{array}{l}0,65 \\
0,65\end{array}$ & 0,61 & 0,56 & 0,56 & $\begin{array}{l}l, 62 \\
0,61\end{array}$ \\
\hline 18 & Fab. de calģados e de artigos de couro e peles & 0,60 & 0,51 & 0,45 & 0,51 & 0,48 & 0,45 & 0,44 & 0,40 & 0,38 & 0,39 \\
\hline 19 & Indústria de alimentos em geral & 8,89 & 8,51 & 8,39 & 8,06 & 8,31 & 9,00 & 9,02 & 8,52 & 8,30 & 7,89 \\
\hline 20 & Indústrias diversas & 0,43 & 0,44 & 0,46 & 0,45 & 0,45 & 0,46 & 0,47 & 0,48 & 0,49 & 0,56 \\
\hline 21 & Servicos industriais de uttilidade pubblica & 2,35 & 2,85 & 2,78 & 2,68 & 2,55 & 2,44 & 2,43 & 2,54 & 3,00 & 3,12 \\
\hline 22 & Construção civil & 10,78 & 10,34 & 9,41 & 9,24 & 8,96 & 8,32 & 8,19 & 8,55 & 8,58 & 8,24 \\
\hline 23 & Comércio & 5,88 & 5,85 & 6,17 & 6,86 & 6,57 & 6,95 & 7,39 & 7,67 & 7,60 & 7,32 \\
\hline 24 & Transporte & 3,16 & 3,01 & 3,40 & 3,57 & 3,51 & 3,49 & 3,65 & 3,55 & 3,49 & 3,56 \\
\hline 25 & Comunicą̧ōes & 0,49 & 0,68 & 0,64 & 0,71 & 0,78 & 0,86 & 0,95 & 0,98 & 1,48 & 2,07 \\
\hline 26 & Instititiçöes financeiras & 5,15 & 5,10 & 4,65 & 4,38 & 4,45 & 4,58 & 4,76 & 4,88 & $\begin{array}{l}4,902 \\
4,92-10\end{array}$ & 4,78 \\
\hline 27 & Servicos prestados æ̇ familias & 6,11 & 5,94 & 6,27 & 6,17 & 6,32 & 5,89 & 5,62 & 5,59 & 5,40 & 5,53 \\
\hline 28 & Senvigos prestados æ̇ empresas & 1,92 & 1,96 & 2,17 & 2,25 & 2,41 & 2,57 & 2,55 & 2,60 & 2,77 & 2,93 \\
\hline 29 & Aluguel de imóveis & 7,43 & 7,30 & 7,76 & 7,75 & 7,86 & 7,72 & 7,52 & 7,47 & 7,66 & 7,51 \\
\hline 30 & Administraçăo pública & 11,12 & 11,97 & 12,64 & 13,20 & 12,36 & 12,61 & 11,60 & 11,65 & 11,98 & 11,75 \\
\hline 31 & Serviços privados não-mercantis & 0,69 & 0,71 & 0,73 & 0,74 & 0,75 & 0,76 & 0,70 & 0,70 & 0,69 & 0,68 \\
\hline
\end{tabular}


ANEXO C - Participação relativa dos setores no valor adicionado.

\begin{tabular}{|c|c|c|c|c|c|c|c|c|c|c|c|}
\hline & $x_{3}$ & 1990 & 1991 & 1992 & 1993 & 1994 & 1995 & 1996 & 1997 & 1998 & 1999 \\
\hline 1 & Agropecuária & 7,20 & 7,23 & 7,63 & 7,36 & 7,42 & 7,54 & 7,59 & 7,31 & 7,40 & 7,81 \\
\hline 2 & Extrativa mineral (exceto combustiveis) & 0.54 & 0.54 & 0.52 & 0.51 & 0.51 & 0.52 & 0.52 & 0.52 & 0,47 & 0,44 \\
\hline 3 & Ext.de petróleo e gás natural, carão e outros comb. & 0,80 & 0,76 & 0,76 & 0,74 & 0,76 & 0,76 & 0,83 & 0,86 & 0,87 & 1,03 \\
\hline 4 & Fabricaçăo de minerais näo-metâlicos & 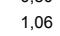 & 1,06 & 0,99 & 1,01 & 1,01 & 1,02 & 1,01 & 1,04 & 0,98 & 0,96 \\
\hline 5 & Siderurgia, met ñ-ferrosos e out.prod.metalurgricos & $\begin{array}{l}1,00 \\
2,34\end{array}$ & 2,32 & 2,29 & $\begin{array}{l}2,39 \\
2,39-200\end{array}$ & 2,55 & $\begin{array}{l}2,424 \\
2,44\end{array}$ & 2,41 & $\begin{array}{l}1,04 \\
2,44\end{array}$ & 2,23 & 2,05 \\
\hline 6 & Fabricação e manutençăo de máquinas e tratores & 1,99 & 1,82 & 1,76 & 1,93 & 2,09 & 2,00 & 1,97 & 2,00 & 1,83 & 1,89 \\
\hline 7 & Fab.de ap.e equip.de matelétrico eletrônico & 1,03 & 0,99 & 0,84 & 0,94 & 1,12 & 1,24 & 1,25 & 1,19 & 1,13 & 0,96 \\
\hline 8 & Fab.auto.cam.onib.out.veic, pecas e acessórios & 1,18 & 1,22 & 1,19 & 1,39 & 1,51 & 1,51 & 1,48 & 1,58 & 1,33 & 1,31 \\
\hline 9 & Serrarias e fab. de artigos de madeira e mobiliário & 0,81 & 0,74 & 0,70 & 0,76 & 0,73 & 0,73 & 0,73 & 0,72 & 0,67 & 0,76 \\
\hline 10 & Indústria de papel e gráfica & 0,92 & 0,96 & 0,95 & 1,01 & 1,00 & 0,99 & 0,98 & 0,97 & 0,94 & 0,99 \\
\hline 11 & Indústria da borracha & 0,40 & 0,40 & 0,40 & 0,42 & 0,41 & 0,40 & 0,39 & 0,39 & 0,34 & 0,27 \\
\hline 12 & Fab. Elem. quimicos não-petroq.e quim.diversos & 1,89 & 2,02 & 1,90 & 1,90 & 1,90 & 1,86 & 1,91 & 1,95 & 1,74 & 1,71 \\
\hline 13 & Refino de petróleo e indústria petroquímica & 2,91 & 3,03 & 3,06 & 3,13 & 3,14 & 2,99 & 2,80 & 2,92 & 3,03 & 2,87 \\
\hline 14 & Fab. de produtos farmacêuticos e de perfumaria & 0,78 & 0,81 & 0,76 & 0,80 & 0,75 & 0,82 & 0,79 & 0,82 & 0,85 & 0,89 \\
\hline 15 & Indústria de transformaçăo de material plástico & 0,56 & 0,55 & 0,49 & 0,51 & 0,50 & 0,53 & 0,57 & 0,56 & 0,52 & 0,39 \\
\hline 16 & Indústria têxtil & 0,81 & 0,76 & 0,73 & 0,73 & 0,71 & 0,65 & 0,60 & 0,54 & 0,51 & 0,50 \\
\hline 17 & Fabricąăo de artigos do vestuário e acessórios & 0,59 & 0,50 & 0,46 & 0,46 & 0,46 & 0,45 & 0,43 & 0 & 0,40 & 0,43 \\
\hline 18 & Fab. de calçados e de artigos de couro e peles & 0,33 & 0,30 & 0,32 & 0,35 & 0,31 & 0,28 & 0,28 & 0,26 & 0,24 & 0,28 \\
\hline 19 & Indústria de alimentos em geral & 3,53 & 3,62 & 3,61 & 3,60 & 3,54 & 3,75 & 3,72 & 3,64 & 3,58 & 3,62 \\
\hline 20 & Indústrias diversas & 0,41 & 0,42 & 0,41 & 0,41 & 0,42 & 0,41 & 0,40 & 0,40 & 0,39 & 0,41 \\
\hline 21 & Servicos industriais de utilidade pública & 2,17 & 2,30 & 2,31 & 2,34 & 2,33 & 2,45 & 2,53 & 2,60 & 3,10 & 3,20 \\
\hline 22 & Construção civil & 9,44 & 9,24 & 8,71 & 8,79 & 8,98 & 8,74 & 8,97 & 9,37 & 9,48 & 9,00 \\
\hline 23 & Comércio & 7,14 & 7,02 & 6,81 & 7,10 & 7,42 & 7,87 & 7,82 & 7,82 & 7,30 & 6,81 \\
\hline 24 & Transporte & 2,87 & 2,89 & 2,98 & 3,00 & 2,99 & 3,11 & 3,12 & 3,14 & 2,93 & 2,59 \\
\hline 25 & Comunicaçöes & 0,74 & 0,87 & 0,92 & 0,98 & 1,07 & 1,29 & 1,39 & 1,42 & 2,13 & 3,09 \\
\hline 26 & Instituiçōes financeiras & 8,59 & 8,12 & 7,77 & 7,36 & 6,83 & 6,14 & 6,14 & 6,15 & 6,10 & 6,05 \\
\hline 27 & Servicos prestados às familias & 6,26 & 6,23 & 6,45 & 6,43 & 6,43 & 6,39 & 6,38 & 6,24 & 5,82 & 5,59 \\
\hline 28 & Sevviços prestados às empresas & 2,68 & 2,84 & 3,04 & 3,09 & 3,16 & 3,30 & 3,38 & 3,45 & 3,64 & 3,72 \\
\hline 29 & Aluguel de imóveis & 12,97 & 13,23 & 13,62 & 13,12 & 13,20 & 13,26 & 13,28 & 13,22 & 13,54 & 13,59 \\
\hline 30 & Administraçāo publica & 15,85 & 15,96 & 16,37 & 16,16 & 15,50 & 15,27 & 15,11 & 14,92 & 15,34 & 15,58 \\
\hline 31 & Serviços privados nâo-mercantis & 1,22 & 1,23 & 1,25 & 1,25 & 1,25 & 1,28 & 1,20 & 1,19 & 1,17 & 1,19 \\
\hline
\end{tabular}




\begin{tabular}{|c|c|c|c|c|c|c|c|c|c|c|c|}
\hline & Setor & 1990 & 1991 & 1992 & 1993 & 1994 & 1995 & 1996 & 1997 & 1998 & 1999 \\
\hline 1 & Agropecuária & 22,45 & 25,86 & 26,40 & 26,11 & 25,44 & 24,77 & 23,27 & 22,75 & 21,88 & 23,01 \\
\hline 2 & Extrativa mineral (exceto combustiveis) & 0,51 & 0,47 & 0,44 & 0,41 & 0,41 & 0,38 & 0,35 & 0,34 & 0,34 & \\
\hline 3 & Ext.de perroleo e gás natural, carvão e outros comb. & 0,06 & 0,06 & 0,06 & 0,05 & 0,05 & 0,05 & 0,04 & 0,04 & 0,04 & 0,06 \\
\hline 4 & Fabricação de minerais não-metálicos & 0,93 & 0,86 & 0,81 & 0,77 & 0,77 & 0,73 & 0,73 & 0,75 & 0,68 & 0,69 \\
\hline 5 & Siderurgia, met tr-ferrosos e out.prod.metalurgicos & 1,56 & 1,45 & 1,33 & 1,26 & 1,26 & 1,28 & 1,28 & 1,28 & 1,30 & 1,17 \\
\hline 6 & Fabricaçăo e manutençăo de máquinas e tratores & 0,89 & 0,77 & 0,73 & 0,71 & 0,71 & 0,70 & 0,70 & 0,69 & 0,64 & 0,61 \\
\hline 7 & Fab.de ap.e equip.de matelétrico eletrônico & 0,63 & 0,53 & 0,43 & 0,44 & 0,44 & 0,43 & 0,43 & 0,41 & 0,38 & 0,33 \\
\hline 8 & Fab.auto.cam.onib.out.veic,. peças e acessoŕrios & 0,68 & 0,60 & 0,53 & 0,55 & 0,55 & 0,49 & 0,49 & 0,48 & 0,43 & 0,45 \\
\hline 9 & Serraras e fab. de artigos de madeira e mobiliário & 1,50 & 1,38 & 1,28 & 1,37 & 1,37 & 1,43 & 1,43 & 1,39 & 1,30 & 1,30 \\
\hline 10 & Indústria de papel e gráfica & 0,78 & 0,76 & 0,74 & 0,71 & 0,71 & 0,71 & 0,71 & 0,68 & 0,68 & 0,67 \\
\hline 11 & Indústria da borracha & 0,14 & 0,13 & 0,13 & 0,12 & 0,12 & 0,09 & 0,09 & 0,09 & 0,08 & 0,07 \\
\hline 12 & Fab. Elem. químicos não-petroq.e quím.diversos & 0,49 & 0,49 & 0,45 & 0,40 & 0,40 & 0,39 & 0,39 & 0,40 & 0,36 & 0,33 \\
\hline 13 & Refino de pertoleo e indússtria pertroquimica & 0,15 & 0,14 & 0,13 & 0,12 & 0,12 & 0,10 & 0,10 & 0,10 & 0,08 & 0,07 \\
\hline 14 & Fab. de produtos farmacêuticos e de perfumaria & 0,20 & 0,20 & 0,20 & 0,20 & 0,20 & 0,21 & 0,21 & 0,21 & 0,21 & 0,19 \\
\hline 15 & Indústria de transformação de material plástico & 0,33 & 0,31 & 0,28 & 0,27 & 0,27 & 0,30 & 0,30 & 0,30 & 0,30 & 0,33 \\
\hline 16 & Induststra têxxil & 0,70 & 0,65 & 0,61 & 0,57 & 0,57 & 0,41 & 0,41 & 0 & 0,38 & 0,38 \\
\hline 17 & Fabricaç̧ăo de artigos do vestuário e acessórios & 2,87 & 2,67 & 2,53 & 2,66 & 2,66 & 2,66 & 2,66 & 2,41 & 2,32 & 2,32 \\
\hline 18 & Fab. de calcados e de artigos de couro e peles & 0,74 & 0,69 & 0,69 & 0,67 & 0,67 & 0,58 & 0,58 & 0,53 & 0,55 & 0,54 \\
\hline 19 & Indústria de alimentos em geral & 2,47 & 2,54 & 2,56 & 2,48 & 2,48 & 2,49 & 2,49 & 2,46 & 2,42 & 2,33 \\
\hline 20 & Indústrias diversas & 0,45 & 0,46 & 0,48 & 0,47 & 0,47 & 0,39 & 0,39 & 0,40 & 0,45 & 0,44 \\
\hline 21 & Serviços industriais de utilidade pública & 0,55 & 0,52 & 0,49 & 0,47 & 0,47 & 0,39 & 0,39 & 0,39 & 0,39 & 0,35 \\
\hline 22 & Construçăo civil & 6,72 & 6,24 & 5,82 & 5,77 & 5,77 & $\begin{array}{l}5,89 \\
5\end{array}$ & 5,89 & 6,16 & 6,64 & 6,26 \\
\hline 23 & Comércio & 13,01 & 13,00 & 13,08 & 14,15 & 14,15 & 14,63 & 14,63 & 14,77 & 14,94 & $\begin{array}{l}14,94 \\
-24\end{array}$ \\
\hline 24 & Transporte & 3,56 & 3,49 & 3,44 & 3,58 & 3,58 & 3,78 & 3,78 & 3,94 & 3,97 & 3,82 \\
\hline 25 & Comunicą̧⿻一㇂㇒s & $\begin{array}{l}0,30 \\
0,30\end{array}$ & $\begin{array}{l}3,49 \\
0,28\end{array}$ & $\begin{array}{l}3,44 \\
0,29\end{array}$ & $\begin{array}{l}3,36 \\
0,31\end{array}$ & 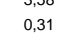 & 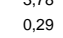 & $\begin{array}{l}3,16 \\
0,29\end{array}$ & $\begin{array}{l}0,24 \\
0,28\end{array}$ & $\begin{array}{l}0,34 \\
0,3 / 2\end{array}$ & $\begin{array}{l}0,62 \\
0,33\end{array}$ \\
\hline 26 & Instituiç̄es financeiras & $\begin{array}{l}0,30 \\
1,72\end{array}$ & $\begin{array}{l}0,56 \\
1,57\end{array}$ & $\begin{array}{l}0,29 \\
1,47\end{array}$ & $\begin{array}{l}0,31 \\
1,39\end{array}$ & $\begin{array}{l}0,11 \\
1,39\end{array}$ & $\begin{array}{l}0,29 \\
1,25\end{array}$ & $\begin{array}{l}0,29 \\
1,25\end{array}$ & $\begin{array}{l}0,26 \\
1,25\end{array}$ & $\begin{array}{l}0,34 \\
1,14\end{array}$ & $\begin{array}{l}0,33 \\
1,12 \\
-10\end{array}$ \\
\hline 27 & Servicos prestados às familias & 12,77 & 12,79 & 12,87 & 13,37 & 13,37 & 14,72 & 14,72 & 14,94 & 15,28 & 15,17 \\
\hline 28 & 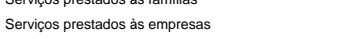 & $\begin{array}{r}2,, 11 \\
2,51\end{array}$ & $\begin{array}{r}22,19 \\
2,67\end{array}$ & $\begin{array}{r}2,81 \\
2,85\end{array}$ & $\begin{array}{r}13,31 \\
3,07\end{array}$ & $\begin{array}{r}15,367 \\
3,07\end{array}$ & $\begin{array}{r}11,12 \\
3,64\end{array}$ & $\begin{array}{r}14,42 \\
3,64\end{array}$ & $\begin{array}{r}44,94 \\
3,77\end{array}$ & $\begin{array}{r}55,28 \\
4,06\end{array}$ & $\begin{array}{r}\begin{array}{r}55,17 \\
3,93\end{array} \\
0\end{array}$ \\
\hline 29 & Aluguel de imoveis & $\begin{array}{l}2,51 \\
0,53\end{array}$ & $\begin{array}{l}2,61 \\
0,46\end{array}$ & $\begin{array}{l}2,83 \\
0,41\end{array}$ & $\begin{array}{l}3,07 \\
0,42\end{array}$ & $\begin{array}{l}3,01 \\
0,42\end{array}$ & $\begin{array}{l}3,04 \\
0,47\end{array}$ & $\begin{array}{l}3,04 \\
0,47\end{array}$ & $\begin{array}{l}3,45 \\
0,45\end{array}$ & $\begin{array}{l}4,40 \\
0,42\end{array}$ & $\begin{array}{l}3,93 \\
0,44\end{array}-x-3$ \\
\hline 30 & Adminisistração püblica & 9,75 & 10,15 & 10,60 & 9,33 & 9,33 & 8,69 & 8,98 & 8,87 & 9,06 & 9,06 \\
\hline 31 & Servicoss privados näa-mercantis & $\begin{array}{r}9,15 \\
7,03 \\
\end{array}$ & $\begin{array}{r}0,15 \\
7,80 \\
\end{array}$ & $\begin{array}{r}10,60 \\
7,86 \\
\end{array}$ & $\begin{array}{l}9,33 \\
8,47 \\
\end{array}-10$ & $\begin{array}{l}\begin{array}{r}3,33 \\
8,47\end{array} \\
-\end{array}$ & $\begin{array}{l}8,89 \\
8,83 \\
-10\end{array}$ & $\begin{array}{l}8,98 \\
8,93 \\
\end{array}$ & $\begin{array}{l}8,87 \\
9,07 \\
\end{array}$ & $\begin{array}{l}8,63 \\
8,06 \\
8\end{array}$ & 8,966 \\
\hline
\end{tabular}


ANEXO E - Índice de turbulência.

\begin{tabular}{|c|c|c|c|c|c|c|c|c|c|c|c|}
\hline & Setores & $1991 / 1990$ & $1992 / 1991$ & $1993 / 1992$ & $1994 / 1993$ & $1995 / 1994$ & $1996 / 1995$ & $1997 / 1996$ & $1998 / 1997$ & 1999/1998 & $1999 / 1990$ \\
\hline 01 & Agropecuária & 0,00205 & 0,00267 & 0,00143 & 0,00339 & 0,00335 & 0,00749 & 0,00258 & 0,00438 & 0,00568 & 0,01222 \\
\hline 02 & Extrativa mineral (exceto combustíveis) & 0,00021 & 0,00015 & 0,00005 & 0,00021 & 0,00016 & 0,00015 & 0,00002 & 0,00000 & 0,00019 & 0,00105 \\
\hline 03 & Ext.de petróleo e gás natural, carvão e outros comb. & 0,00001 & 0,00001 & 0,00003 & 0,00000 & 0,00000 & 0,00003 & 0,00001 & 0,00002 & 0,00007 & 0,00001 \\
\hline 04 & Fabricação de minerais não-metálicos & 0,00037 & 0,00025 & 0,00011 & 0,00010 & 0,00020 & 0,00002 & 0,00012 & 0,00036 & 0,00004 & 0,00121 \\
\hline 05 & Siderurgia, met ñ-ferrosos e out.prod.metalurgicos & 0,00058 & 0,00057 & 0,00031 & 0,00005 & 0,00007 & 0,00017 & 0,00001 & 0,00009 & 0,00068 & 0,00198 \\
\hline 06 & Fabricação e manutenção de máquinas e tratores & 0,00061 & 0,00018 & 0,00018 & 0,00009 & 0,00012 & 0,00005 & 0,00006 & 0,00024 & 0,00014 & 0,00139 \\
\hline 07 & Fab.de ap.e equip.de mat.elétrico eletrônico & 0,00047 & 0,00052 & 0,00008 & 0,00015 & 0,00005 & 0,00013 & 0,00009 & 0,00014 & 0,00023 & 0,00146 \\
\hline 08 & Fab.auto.cam.onib.out.veic., peças e acessórios & 0,00040 & 0,00034 & 0,00004 & 0,00004 & 0,00010 & 0,00020 & 0,00004 & 0,00025 & 0,00010 & 0,00116 \\
\hline 09 & Serrarias e fab. de artigos de madeira e mobiliário & 0,00059 & 0,00049 & 0,00044 & 0,00000 & 0,00002 & 0,00028 & 0,00022 & 0,00045 & 0,00002 & 0,00099 \\
\hline 10 & Indústria de papel e gráfica & 0,00012 & 0,00009 & 0,00028 & 0,00011 & 0,00001 & 0,00000 & 0,00012 & 0,00004 & 0,00003 & 0,00057 \\
\hline 11 & Indústria da borracha & 0,00004 & 0,00003 & 0,00003 & 0,00002 & 0,00004 & 0,00009 & 0,00002 & 0,00004 & 0,00002 & 0,00033 \\
\hline 12 & Fab. Elem. químicos não-petroq.e quím.diversos & 0,00002 & 0,00018 & 0,00020 & 0,00008 & 0,00006 & 0,00000 & 0,00007 & 0,00018 & 0,00015 & 0,00080 \\
\hline 13 & Refino de petróleo e indústria petroquímica & 0,00005 & 0,00005 & 0,00000 & 0,00003 & 0,00007 & 0,00004 & 0,00002 & 0,00009 & 0,00004 & 0,00039 \\
\hline 14 & Fab. de produtos farmacêuticos e de perfumaria & 0,00001 & 0,00001 & 0,00005 & 0,00004 & 0,00003 & 0,00000 & 0,00000 & 0,00001 & 0,00010 & 0,00006 \\
\hline 15 & Indústria de transformação de material plástico & 0,00010 & 0,00013 & 0,00001 & 0,00008 & 0,00001 & 0,00016 & 0,00002 & 0,00000 & 0,00013 & 0,00001 \\
\hline 16 & Indústria têxtil & 0,00024 & 0,00021 & 0,00005 & 0,00013 & 0,00034 & 0,00045 & 0,00009 & 0,00007 & 0,00001 & 0,00158 \\
\hline 17 & Fabricação de artigos do vestuário e acessórios & 0,00099 & 0,00069 & 0,00056 & 0,00011 & 0,00011 & 0,00014 & 0,00124 & 0,00045 & 0,00003 & 0,00271 \\
\hline 18 & Fab. de calçados e de artigos de couro e peles & 0,00026 & 0,00002 & 0,00016 & 0,00025 & 0,00039 & 0,00007 & 0,00021 & 0,00008 & 0,00007 & 0,00102 \\
\hline 19 & Indústria de alimentos em geral & 0,00033 & 0,00009 & 0,00035 & 0,00001 & 0,00013 & 0,00011 & 0,00012 & 0,00023 & 0,00042 & 0,00070 \\
\hline 20 & Indústrias diversas & 0,00005 & 0,00010 & 0,00003 & 0,00008 & 0,00015 & 0,00029 & 0,00006 & 0,00023 & 0,00000 & 0,00004 \\
\hline 21 & Serviços industriais de utilidade pública & 0,00017 & 0,00015 & 0,00019 & 0,00030 & 0,00026 & 0,00014 & 0,00000 & 0,00001 & 0,00023 & 0,00104 \\
\hline 22 & Construção civil & 0,00241 & 0,00206 & 0,00065 & 0,00093 & 0,00083 & 0,00147 & 0,00130 & 0,00243 & 0,00190 & 0,00228 \\
\hline 23 & Comércio & 0,00002 & 0,00037 & 0,00373 & 0,00166 & 0,00168 & 0,00071 & 0,00072 & 0,00081 & 0,00000 & 0,00966 \\
\hline 24 & Transporte & 0,00036 & 0,00024 & 0,00010 & 0,00058 & 0,00060 & 0,00041 & 0,00079 & 0,00017 & 0,00077 & 0,00128 \\
\hline 25 & Comunicações & 0,00006 & 0,00003 & 0,00004 & 0,00003 & 0,00004 & 0,00004 & 0,00008 & 0,00034 & 0,00004 & 0,00019 \\
\hline 26 & Instituições financeiras & 0,00072 & 0,00051 & 0,00006 & 0,00046 & 0,00043 & 0,00025 & 0,00003 & 0,00055 & 0,00007 & 0,00296 \\
\hline 27 & Serviços prestados às famílias & 0,00008 & 0,00041 & 0,00114 & 0,00366 & 0,00387 & 0,00284 & 0,00113 & 0,00171 & 0,00060 & 0,01196 \\
\hline 28 & Serviços prestados às empresas & 0,00078 & 0,00089 & 0,00005 & 0,00115 & 0,00125 & 0,00158 & 0,00066 & 0,00145 & 0,00063 & 0,00709 \\
\hline 29 & Aluguel de imóveis & 0,00036 & 0,00026 & 0,00015 & 0,00020 & 0,00024 & 0,00001 & 0,00009 & 0,00012 & 0,00010 & 0,00045 \\
\hline 30 & Administração pública & 0,00197 & 0,00226 & 0,00297 & 0,00339 & 0,00318 & 0,00145 & 0,00056 & 0,00097 & 0,00002 & 0,00347 \\
\hline 31 & Serviços privados não-mercantis & 0,00387 & 0,00030 & 0,00127 & 0,00175 & 0,00183 & 0,00047 & 0,00074 & 0,00073 & 0,00016 & 0,00967 \\
\hline
\end{tabular}


ANEXO F - Multiplicadores de produção do tipo I.

\begin{tabular}{|c|c|c|c|c|c|c|c|c|c|c|c|}
\hline & Setor & 1990 & 1991 & 1992 & 1993 & 1994 & 1995 & 1996 & 1997 & 1998 & 1999 \\
\hline 2 & Extrativa mineral (exceto combustiveis) & 2,29 & 2,09 & 2,09 & 2,17 & 2,20 & 1,97 & 2,04 & 1,93 & 1,94 & 1,84 \\
\hline 4 & Fabricação de minerais não-metálicos & 2,44 & 2,32 & 2,36 & 2,28 & 2,21 & 2,00 & 2,07 & 1,87 & 1,86 & 1,92 \\
\hline 5 & Siderurgial, met ñ-ferrosos e out.prod.metalurgicos & 2,92 & 2,78 & 2,84 & 2,74 & 2,71 & 2,32 & 2,38 & 2,31 & 2,31 & 2,34 \\
\hline 6 & Fabricaçăo e manutençăo de máquinas e tratores & 2,39 & 2,29 & 2,19 & 2,00 & 2,07 & 1,77 & 1,79 & 1,70 & 1,70 & 1,69 \\
\hline 7 & Fab.de ap.e equip.de mateleletrico eletrônico & 2,60 & 2,54 & 2,54 & 2,50 & 2,49 & 1,91 & 1,93 & 1,96 & 1,93 & 1,98 \\
\hline 8 & Fab.auto.cam.onib.out.veic., peças e acessororios & 2,95 & 2,82 & 2,81 & 2,71 & 2,69 & 2,20 & 2,23 & 2,10 & 2,06 & 2,07 \\
\hline 9 & Serrarias e fab. de artigos de madeira e mobiliário & 2,45 & 2,33 & 2,42 & 2,27 & 2,23 & 1,99 & 2,06 & 1,96 & 1,97 & 1,96 \\
\hline 10 & Indústria de papel e gráfica & 2,67 & 2,51 & 2,65 & 2,68 & 2,64 & 2,13 & 2,21 & 2,12 & 2,15 & 2,11 \\
\hline 11 & Indústria da borracha & 2,77 & 2,76 & 2,70 & 2,57 & 2,60 & 2,13 & 2,17 & 2,06 & 2,04 & 2,10 \\
\hline 12 & Fab. Elem. quimicos não-petroq.e quím.diversos & 2,54 & 2,48 & 2,49 & 2,28 & 2,37 & 2,01 & 2,05 & 2,03 & 2,04 & 1,99 \\
\hline 13 & Refino de petroleo e indústria petroquuricica & 2,49 & 2,58 & 2,37 & 2,02 & 2,17 & 1,79 & 1,89 & 1,85 & 1,81 & 1,90 \\
\hline 14 & Fab. de produtos farmaceuticos e de perfumaria & 2,46 & 2,57 & 2,36 & 2,18 & 2,21 & 1,81 & 1,83 & 1,83 & 1,80 & 1,87 \\
\hline 15 & Indústria de transformaçăo de material plástico & 2,36 & 2,45 & 2,42 & 2,18 & 2,29 & 1,91 & 1,93 & 1,88 & 1,87 & 2,01 \\
\hline 16 & Indústria têxill & 2,71 & 2,83 & 2,83 & 2,68 & 2,77 & 2,22 & 2,23 & 2,20 & 2,28 & 2,36 \\
\hline 17 & Fabricaçăo de artigos do vestuário e acessorrios & 2,56 & 2,65 & 2,63 & 2,57 & 2,60 & 2,18 & 2,22 & 2,07 & 2,09 & 2,17 \\
\hline 18 & Fab. de calçados e de arigos de couro e peles & 2,85 & 2,74 & 2,53 & 2,47 & 2,55 & 2,19 & 2,21 & 2,06 & 2,05 & 2,02 \\
\hline 19 & Indústria de alimentos em geral & 2,79 & 2,73 & 2,70 & 2,64 & 2,60 & 2,34 & 2,38 & 2,27 & 2,26 & 2,30 \\
\hline 20 & Indústrias diversas & 2,16 & 2,11 & 2,14 & 2,05 & 2,05 & 1,91 & 1,91 & 1,83 & 1,85 & 1,91 \\
\hline 21 & Servicos industriais de utilidade pública & 2,10 & 2,21 & 2,15 & 2,07 & 2,00 & 1,58 & 1,56 & 1,63 & 1,61 & 1,64 \\
\hline 22 & 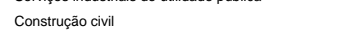 & 2,37 & 2,28 & 2,22 & 2,12 & 2,04 & $\begin{array}{l}1,62 \\
1,62\end{array}$ & $\begin{array}{l}1,60 \\
1,60\end{array}$ & 1,64 & 1,63 & 1,68 \\
\hline 23 & Comércio & 1,79 & 1,78 & $\begin{array}{l}2,85 \\
1,8\end{array}$ & 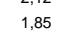 & 1,76 & 1,55 & $\begin{array}{l}1,64 \\
1,64\end{array}$ & $\begin{array}{l}1,68 \\
1,68\end{array}$ & 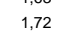 & 1,79 \\
\hline 24 & Transporte & 2,27 & 2,19 & 2,23 & 2,17 & 2,19 & 1,65 & 1,76 & 1,79 & 1,82 & 1,93 \\
\hline 25 & Comunicaăoses & 1,46 & 1,66 & 1,46 & 1,50 & 1,50 & 1,24 & 1,26 & 1,29 & 1,29 & 1,27 \\
\hline 26 & Institiuiç̄es financeiras & 1,23 & 1,27 & 1,17 & 1,15 & 1,27 & 1,35 & 1,40 & 1,42 & 1,43 & 1,44 \\
\hline 27 & Servicos prestados às familias & 2,21 & 2,13 & 2,12 & 2,05 & 2,07 & 1,62 & 1,59 & 1,62 & 1,64 & 1,73 \\
\hline 28 & Servicos prestados às empresas & 1,60 & 1,51 & 1,53 & 1,53 & 1,59 & 1,41 & 1,41 & 1,40 & 1,40 & 1,46 \\
\hline 29 & 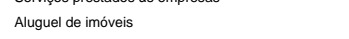 & 1,23 & $\begin{array}{l}1,110 \\
1,10\end{array}$ & $\begin{array}{l}1,1,13 \\
1,13\end{array}$ & $\begin{array}{l}1,1,18 \\
1,18\end{array}$ & $\begin{array}{l}1,138 \\
1,18-1\end{array}$ & $\begin{array}{l}1,41 \\
1,09\end{array}$ & $\begin{array}{l}1,41 \\
1,06\end{array}$ & $\begin{array}{l}1,106 \\
1,06\end{array}$ & $\begin{array}{l}1,40 \\
1,06\end{array}$ & $\begin{array}{l}1,140 \\
1,07\end{array}$ \\
\hline 30 & Administraçẵo publica & 1,53 & 1,59 & 1,60 & 1,65 & 1,61 & 1,47 & 1,42 & 1,44 & 1,43 & 1,43 \\
\hline
\end{tabular}




\begin{tabular}{|c|c|c|c|c|c|c|c|c|c|c|c|}
\hline 1 & Agropecuária & 3,39 & 3,76 & 3,54 & 3,20 & 3,36 & 2,89 & 3,17 & 3,17 & 3,03 & 3,16 \\
\hline 2 & Extrativa mineral (exceto combustiveis) & 4,59 & 4,44 & 4,01 & 3,88 & 4,33 & 3,41 & 3,72 & 3,53 & 3,44 & 3,24 \\
\hline 3 & Ext.de pertroleo e gás natural, carvão e ourros comb. & 3,01 & 3,51 & 3,32 & 3,09 & 3,67 & 3,03 & 3,13 & 3,06 & 3,29 & 2,84 \\
\hline 4 & Fabricaçăo de minerais não-metálicos & 4,40 & 4,46 & 4,19 & 3,77 & 4,06 & 3,33 & 3,67 & 3,35 & 3,23 & 3,29 \\
\hline 5 & Siderurgia, met ñ.-errososos e out.prod.metaluurgicos & 5,13 & 5,20 & 4,82 & 4,37 & 4,71 & 3,62 & 3,93 & 3,77 & 3,69 & 3,62 \\
\hline 6 & Fabricą̧ão e manutençăo de máquinas etratores & 4,59 & 4,78 & 4,21 & 3,51 & 4,09 & 3,13 & 3,42 & 3,26 & 3,18 & 3,14 \\
\hline 7 & Fab.de ap.e equip.de matelérticice eletrônico & 4,60 & 4,82 & 4,40 & 4,02 & 4,43 & 3,06 & 3,27 & 3,32 & 3,22 & 3,20 \\
\hline 8 & Fab.auto.cam.onib.out.veic., peças e acessorrios & 5,22 & 5,55 & 5,07 & 4,37 & 4,73 & 3,43 & 3,66 & 3,46 & 3,34 & 3,27 \\
\hline 9 & Serraraias e tab. de artigos de madeira e mobiliáríio & 4,74 & 4,80 & 4,57 & 4,05 & 4,35 & 3,50 & 3,80 & 3,63 & 3,58 & 3,52 \\
\hline 10 & Indústria de papel e gráfica & 5,26 & 5,08 & 4,98 & 4,78 & 5,14 & 3,59 & 3,91 & 3,75 & 3,71 & 3,56 \\
\hline 11 & Indústria da borracha & 4,48 & 4,85 & 4,40 & 3,84 & 4,33 & 3,26 & 3,51 & 3,35 & 3,26 & 3,24 \\
\hline 12 & Fab. Elem. químicos não-petroq.e quím.diversos & 4,38 & 4,60 & 4,27 & 3,59 & 4,11 & 3,21 & 3,45 & 3,42 & 3,34 & 3,24 \\
\hline 13 & Refino de pertóleo e indústria petroquímica & 3,85 & 4,44 & 3,78 & 2,96 & 3,65 & 2,80 & 3,09 & 3,06 & 2,95 & 3,02 \\
\hline 14 & Fab. de produtos farmacêuticos e de perfumaria & 4,35 & 4,89 & 4,20 & 3,63 & 4,13 & 3,07 & 3,29 & 3,32 & 3,20 & 3,21 \\
\hline 15 & Indústria de transtormaçăo de material plasstico & 4,12 & 4,58 & 4,23 & 3,56 & 4,16 & 3,14 & 3,39 & 3,31 & 3,22 & 3,35 \\
\hline 16 & Indústria têxxil & 4,35 & 4,96 & 4,65 & 4,11 & 4,65 & 3,38 & 3,55 & 3,50 & 3,51 & 3,55 \\
\hline 17 & Fabricaçăo de artigos do vestuário e acessoŕrios & 5,07 & 5,62 & 5,18 & 4,83 & 5,29 & 3,76 & 3,98 & 3,77 & 3,71 & 3,76 \\
\hline 18 & Fab. de calçados e de artigos de couro e peles & 5,34 & 5,38 & 4,63 & 4,21 & 4,84 & 3,59 & 3,84 & 3,65 & 3,56 & 3,46 \\
\hline 19 & Indisstria de alimentos em geral & 4,56 & 4,79 & 4,46 & 4,05 & 4,35 & 3,64 & 3,91 & 3,75 & 3,63 & 3,67 \\
\hline 20 & Indústrias diversas & 4,23 & 4,48 & 4,19 & 3,69 & 4,11 & 3,41 & 3,58 & 3,43 & 3,35 & 3,32 \\
\hline 21 & Servicos industriais de utilidade pública & 4,63 & 4,89 & 4,55 & 4,46 & 4,71 & 3,10 & 3,25 & 3,41 & 3,17 & 3,15 \\
\hline 22 & Construçăa civil & 4,39 & 4,55 & 4,07 & 3,57 & 3,80 & 2,82 & 3,01 & 3,09 & 2,98 & 3,04 \\
\hline 23 & Comércio & 4,48 & 4,79 & 4,55 & 4,12 & 4,45 & 3,25 & 3,59 & 3,63 & 3,60 & 3,59 \\
\hline 24 & Transporte & 5,02 & 5,22 & 4,79 & 4,33 & 4,76 & 3,14 & 3,54 & 3,64 & 3,58 & 3,56 \\
\hline 25 & Comunicaçoes & 3,93 & 4,34 & 3,68 & 3,27 & 3,85 & 2,72 & 2,92 & 2,94 & 2,87 & 2,86 \\
\hline 26 & Instituiç̋es financeiras & 3,12 & 3,82 & 3,04 & 2,64 & 3,63 & 3,16 & 3,50 & 3,52 & 3,36 & 3,37 \\
\hline 27 & Servicos prestados às familias & 5,29 & 5,30 & 4,92 & 4,41 & 4,87 & 3,29 & 3,48 & 3,55 & 3,53 & 3,62 \\
\hline 28 & Servicos prestados às empresas & 4,50 & 4,29 & 4,18 & 3,70 & 4,42 & 3,21 & 3,38 & 3,39 & 3,34 & 3,36 \\
\hline 29 & Aluguel de imóveis & 1,89 & 2,13 & 1,91 & 1,74 & 2,22 & 2,19 & 2,40 & 2,43 & 2,30 & 2,42 \\
\hline 30 & Administraçăo pública & 5,68 & 5,60 & 5,31 & 4,97 & 5,47 & 3,65 & 3,83 & 3,85 & 3,75 & 3,76 \\
\hline 31 & Servicos privados nâo-mercantis & 5,58 & $\begin{array}{r}5,53 \\
\end{array}$ & 5,20 & 4,94 & 5,33 & $\begin{array}{l}3,57 \\
\end{array}$ & $\begin{array}{l}3,77 \\
\end{array}$ & 3,75 & 3,68 & 3,72 \\
\hline
\end{tabular}


ANEXO H - Índices de ligação para trás (Rasmussen-Hirschman).

\begin{tabular}{|c|c|c|c|c|c|c|c|c|c|c|c|}
\hline & Setor & 1990 & 1991 & 1992 & 1993 & 1994 & 1995 & 1996 & 1997 & 1998 & 1999 \\
\hline 1 & Agropecuária & 0,90 & 0,90 & 0,93 & 0,93 & 0,87 & 0,90 & 0,91 & 0,92 & 0,91 & 0,95 \\
\hline 2 & Extrativa mineral (exceto combustiveis) & 1,02 & 0,95 & 0,96 & 1,03 & 1,04 & 1,10 & 1,12 & 1,08 & 1,08 & 1,02 \\
\hline 3 & Ext.de petróleo e gás natural, carvăo e outros comb. & 0,76 & 0,78 & 0,81 & 0,85 & 0,86 & 0,93 & 0,88 & 0,88 & 1,02 & 0,80 \\
\hline 4 & Fabricaçăo de minerais năo-metálicos & 1,10 & 1,05 & 1,08 & 1,08 & 1,05 & 1,11 & 1,14 & 1,05 & 1,04 & 1,06 \\
\hline 5 & Siderurgia, met n̂-ferrososs e out.prod.metalurgicicos & 1,31 & 1,27 & 1,30 & 1,31 & 1,28 & 1,29 & 1,30 & 1,29 & 1,29 & 1,29 \\
\hline 6 & Fabricaçăo e manutençăo de máquinas e tratores & 1,07 & 1,04 & 1,01 & 0,95 & 0,98 & 0,98 & 0,98 & 0,95 & 0,95 & 0,93 \\
\hline 7 & Fab.de ap.e equip.de mat.elétrico eletrônico & 1,17 & 1,16 & 1,16 & 1,19 & 1,18 & 1,06 & 1,06 & 1,10 & 1,08 & 1,09 \\
\hline 8 & Fab.auto.cam.onib.out.veic,. peças e acessórios & 1,32 & 1,28 & 1,29 & 1,29 & 1,27 & 1,22 & 1,22 & 1,18 & 1,15 & 1,14 \\
\hline 9 & Serrarias e fab. de artigos de madeira e mobiliário & 1,10 & 1,06 & 1,11 & 1,08 & 1,05 & 1,11 & 1,13 & 1,10 & 1,10 & 1,08 \\
\hline 10 & Indústria de papel e gráfica & 1,20 & 1,14 & 1,22 & 1,27 & 1,25 & 1,18 & 1,21 & 1,19 & 1,20 & 1,16 \\
\hline 11 & Indústria da borracha & 1,24 & 1,25 & 1,24 & 1,22 & 1,23 & 1,18 & 1,19 & 1,15 & 1,14 & 1,16 \\
\hline 12 & Fab. Elem. quimicos nāo-petroq.e quim.diversos & 1,14 & 1,13 & 1,14 & 1,08 & 1,12 & 1,12 & 1,12 & 1,14 & 1,14 & 1,10 \\
\hline 13 & Refino de petróleo e indústria petroquímica & 1,12 & 1,17 & 1,09 & 0,96 & 1,03 & 1,00 & 1,04 & 1,04 & 1,01 & 1,05 \\
\hline 14 & Fab. de produtos farmacêticos e de perfumaria & 1,11 & 1,17 & 1,08 & 1,03 & 1,05 & 1,01 & 1,00 & 1,02 & 1,00 & 1,03 \\
\hline 15 & Indústria de transformaçāo de material plástico & 1,06 & 1,11 & 1,11 & 1,04 & 1,08 & 1,06 & 1,06 & 1,05 & 1,04 & 1,11 \\
\hline 16 & Indústria têxtil & 1,21 & 1,28 & 1,30 & 1,27 & 1,31 & 1,24 & 1,22 & 1,23 & 1,27 & 1,30 \\
\hline 17 & Fabricaçăo de artigos do vestuário e acesssórios & 1,15 & 1,21 & 1,21 & 1,22 & 1,23 & 1,21 & 1,21 & 1,16 & 1,16 & 1,19 \\
\hline 18 & Fab. de calçados e de artigos de couro e peles & 1,28 & 1,25 & 1,16 & 1,17 & 1,21 & 1,21 & 1,21 & 1,15 & 1,14 & 1,11 \\
\hline 19 & Indústria de alimentos em geral & 1,25 & 1,24 & 1,24 & 1,25 & 1,23 & 1,30 & 1,30 & 1,27 & 1,26 & 1,27 \\
\hline 20 & Indústrias diversas & 0,97 & 0,96 & 0,98 & 0,98 & 0,97 & 1,06 & 1,05 & 1,02 & 1,03 & 1,05 \\
\hline 21 & Servicos industriais de utilidade pubblica & 0,94 & 1,00 & 0,99 & 0,98 & 0,95 & 0,88 & 0,86 & 0,92 & 0,90 & 0,90 \\
\hline 22 & Construção civil & 1,06 & 1,04 & 1,02 & 1,01 & 0,97 & 0,90 & 0,88 & 0,92 & 0,91 & 0,92 \\
\hline 23 & Comércio & 0,80 & 0,81 & 0,85 & 0,88 & 0,83 & 0,86 & 0,90 & 0,94 & 0,96 & 0,99 \\
\hline 24 & Transporte & 1,02 & 1,00 & 1,03 & 1,03 & 1,03 & 0,92 & 0,96 & 1,00 & 1,01 & 1,06 \\
\hline 25 & Comunicaçöes & 0,66 & 0,75 & 0,67 & 0,71 & 0,71 & 0,69 & 0,69 & 0,72 & 0,72 & 0,70 \\
\hline 26 & Instituiç̄öes financeiras & 0,55 & 0,58 & 0,54 & 0,55 & 0,60 & 0,75 & 0,77 & 0,80 & 0,80 & 0,79 \\
\hline 27 & Servicos prestados às familias & 0,99 & 0,97 & 0,97 & 0,98 & 0,98 & 0,90 & 0,87 & 0,91 & 0,92 & 0,95 \\
\hline 28 & Serviços prestados às empresas & 0,72 & 0,68 & 0,70 & 0,73 & 0,75 & 0,79 & 0,77 & 0,78 & 0,78 & 0,81 \\
\hline 29 & Aluguel de imóveis & 0,55 & 0,50 & 0,52 & 0,56 & 0,56 & 0,60 & 0,58 & 0,59 & 0,59 & 0,59 \\
\hline 30 & Administraçăo pública & 0,69 & 0,72 & 0,74 & 0,79 & 0,76 & 0,82 & 0,77 & 0,80 & 0,80 & 0,79 \\
\hline 31 & Serviços privados näo-mercantis & 0,54 & 0,54 & 0,55 & 0,57 & 0,57 & 0,62 & 0,61 & 0,62 & 0,62 & 0,61 \\
\hline
\end{tabular}


ANEXO I - Índices de ligação para frente (Rasmussen-Hirschman).

\begin{tabular}{|c|c|c|c|c|c|c|c|c|c|c|c|}
\hline & Setor & 1990 & 1991 & 1992 & 1993 & 1994 & 1995 & 1996 & 1997 & 1998 & 1999 \\
\hline 1 & Agropecuária & 1,56 & 1,56 & 1,57 & 1,58 & 1,74 & 1,61 & 1,63 & 1,56 & 1,60 & 1,51 \\
\hline 2 & Extrativa mineral (exceto combustiveis) & 0,73 & 0,70 & 0,70 & 0,72 & 0,72 & 0,75 & 0,74 & 0,74 & 0,73 & 0,72 \\
\hline 3 & Ext.de pertóleo e gás natural, carvão e outros comb. & 1,23 & 1,25 & 1,16 & 0,98 & 1,01 & 0,79 & 0,85 & 0,85 & 0,77 & 0,99 \\
\hline 4 & Fabricąăo de minerais nâo-metalicos & 0,93 & 0,92 & 0,91 & 0,92 & 0,93 & 0,92 & 0,89 & 0,85 & 0,85 & 0,84 \\
\hline 5 & Siderurgiai, met ñ-ferrososos out.prod.metalurgicos & 2,47 & 2,37 & 2,38 & 2,34 & 2,33 & 2,04 & 1,97 & 1,89 & 1,86 & 1,85 \\
\hline 6 & Fabricaçăo e manutençăo de máquuinas e tratotores & 1,21 & 1,16 & 1,22 & 1,19 & 1,10 & 1,01 & 1,00 & 0,90 & 0,90 & 0,87 \\
\hline 7 & Fab.de ap.e equip.de mate elétrico eletrônico & 0,92 & 0,92 & 0,90 & 0,89 & 0,86 & 0,76 & 0,73 & 0,74 & 0,72 & 0,70 \\
\hline 8 & Fab.auto.cam.onib.outveici, peças e acessosorios & 0,94 & 0,89 & 0,90 & 0,90 & 0,89 & 0,87 & 0,84 & 0,83 & 0,80 & 0,76 \\
\hline 9 & Serrarias e fab. de artigos de maderia e mobiliário & 0,68 & 0,66 & 0,65 & 0,67 & 0,67 & 0,73 & 0,71 & 0,70 & 0,69 & 0,68 \\
\hline 10 & Indústria de papel e gráfica & 1,21 & 1,27 & 1,20 & 1,15 & 1,14 & 1,14 & 1,15 & 1,13 & 1,11 & 1,14 \\
\hline 11 & Indústria da borracha & 0,90 & 0,89 & 0,89 & 0,90 & 0,91 & 0,92 & 0,90 & 0,84 & 0,82 & 0,82 \\
\hline 12 & Fab. Elem. químicos não-petroq.e quim.diversos & 1,59 & 1,58 & 1,56 & 1,56 & 1,54 & 1,33 & 1,34 & 1,34 & 1,35 & 1,40 \\
\hline 13 & Refino de petrolleo e indústria pertroquímica & 2,43 & 2,53 & 2,65 & 2,63 & 2,60 & 2,16 & 2,16 & 2,17 & 2,16 & 2,44 \\
\hline 14 & Fab. de produtos farmacêuticos e de perfumaria & 0,54 & 0,54 & 0,56 & 0,57 & 0,56 & 0,58 & 0,57 & 0,61 & 0,61 & 0,61 \\
\hline 15 & Indústria de transtormaçăo de material plástico & 0,77 & 0,77 & 0,75 & 0,77 & 0,75 & 0,80 & 0,81 & 0,80 & 0,79 & 0,77 \\
\hline 16 & Indústria têxxil & 1,39 & 1,41 & 1,37 & 1,43 & 1,42 & 1,38 & 1,37 & 1,29 & 1,30 & 1,30 \\
\hline 17 & Fabricaçăo de artigos do vestuário e acessórios & 0,48 & 0,48 & 0,48 & 0,49 & 0,49 & 0,57 & 0,56 & 0,57 & 0,56 & 0,56 \\
\hline 18 & Fab. de calçados e de arrigos de couro e peles & 0,62 & 0,61 & 0,58 & 0,59 & 0,61 & 0,68 & 0,67 & 0,66 & 0,65 & 0,64 \\
\hline 19 & Indústria de alimentos em geral & 1,08 & 1,12 & 1,10 & 1,08 & 1,09 & 1,05 & 1,05 & 1,01 & 0,98 & 0,99 \\
\hline 20 & Indústrias diversas & 0,69 & 0,69 & 0,68 & 0,67 & 0,66 & 0,69 & 0,66 & 0,65 & 0,64 & 0,64 \\
\hline 21 & Servicos industriais de utilidade púbica & 1,31 & 1,43 & 1,49 & 1,48 & 1,47 & 1,28 & 1,30 & 1,31 & 1,45 & 1,44 \\
\hline 22 & Construçăa civil & 0,59 & 0,57 & 0,57 & 0,60 & 0,61 & 0,69 & 0,67 & 0,68 & 0,68 & 0,67 \\
\hline 23 & Comercio & 0,90 & 0,92 & 0,92 & 0,95 & 0,93 & 1,41 & 1,39 & 1,68 & 1,68 & 1,63 \\
\hline 24 & Transporte & 0,91 & 0,90 & 0,91 & 0,93 & 0,94 & 1,19 & 1,19 & 1,19 & 1,21 & 1,18 \\
\hline 25 & Comunicaçōes & 0,61 & 0,62 & 0,64 & 0,66 & 0,64 & 0,71 & 0,76 & 0,79 & 0,87 & 0,90 \\
\hline 26 & Instituiç̄ôe financeiras & 0,83 & 0,70 & 0,73 & 0,72 & 0,77 & 0,93 & 0,97 & 1,02 & 0,99 & 0,98 \\
\hline 27 & Servicos prestados às familias & 0,74 & 0,74 & 0,74 & 0,73 & 0,73 & 0,80 & 0,80 & 0,78 & 0,75 & 0,73 \\
\hline 28 & Servicos prestados às empresas & 0,96 & 1,10 & 1,12 & 1,12 & 1,05 & 1,07 & 1,22 & 1,29 & 1,33 & 1,23 \\
\hline 29 & Aluguel de imóveis & 0,55 & 0,56 & 0,56 & 0,57 & 0,60 & 0,75 & 0,74 & 0,77 & 0,76 & 0,72 \\
\hline 30 & Administraçăo publica & 0,79 & 0,65 & 0,65 & 0,73 & 0,74 & 0,83 & 0,79 & 0,80 & 0,81 & \\
\hline 31 & Servicos privados näo-mercantis & 0,45 & $\begin{array}{l}0,45 \\
\end{array}$ & $\begin{array}{l}0,46 \\
0,16\end{array}$ & 0,48 & 0,47 & 0.56 & 0,55 & 0,56 & 0,56 & \\
\hline
\end{tabular}




\begin{tabular}{|c|c|c|c|c|c|c|c|c|c|c|c|}
\hline & (2) & 1990 & 1991 & 1992 & 1993 & 1994 & 1995 & 1996 & 1997 & 1998 & 1999 \\
\hline 1 & Agropecuária & 0,91 & 0,89 & 0,90 & 0,72 & 0,87 & 1,00 & 0,98 & 0,99 & 1,02 & 1,28 \\
\hline 2 & Extrativa mineral (exceto combustiveis) & 0,11 & 0,17 & 0,19 & 0,13 & 0,11 & 0,18 & 0,19 & 0,17 & 0,18 & 0,18 \\
\hline 3 & Ext.de petróleo e gás natural, carvão e outros comb. & $-0,32$ & $-0,32$ & $-0,32$ & $-0,26$ & $-0,28$ & 0,00 & 0,01 & 0,00 & 0,00 & 0,00 \\
\hline 4 & Fabricą̧ăo de minerais não-metálicos & $-0,37$ & $-0,28$ & $-0,28$ & $-0,26$ & $-0,29$ & 0,09 & 0,10 & 0,09 & 0,08 & 0,08 \\
\hline 5 & Siderurgia, met ñ-ferrosos e out.prod.metalurgicos & $-0,01$ & 0,18 & 0,28 & 0,20 & 0,16 & 0,50 & 0,51 & 0,46 & 0,46 & 0,50 \\
\hline 6 & Fabricaçăo e manutençăo de máquinas e tratores & 0,58 & 0,44 & 0,44 & 0,49 & 0,65 & 0,66 & 0,59 & 0,68 & 0,63 & 0,60 \\
\hline 7 & Fab.de ap.e equip.de mat.elétrico eletrônico & 0,92 & 0,81 & 0,69 & 0,73 & 0,87 & 1,25 & 1,27 & 1,12 & 1,00 & 0,90 \\
\hline 8 & Fab.auto.cam.onib.out.veic, pecas e acessórios & 1,12 & 1,07 & 1,05 & 1,23 & 1,38 & 1,81 & 1,81 & 1,80 & 1,49 & 1,43 \\
\hline 9 & Serrarias e fab. de artigos de madeira e mobiliário & 0,40 & 0,36 & 0,37 & 0,39 & 0,38 & 0,47 & 0,50 & 0,47 & 0,43 & 0,45 \\
\hline 10 & Indústria de papel e gráfica & 0,11 & 0,11 & 0,12 & 0,10 & 0,10 & 0,29 & 0,27 & 0,26 & 0,26 & 0,29 \\
\hline 11 & Indústria da borracha & $-0,16$ & $-0,14$ & $-0,13$ & $-0,10$ & $-0,12$ & 0,05 & 0,05 & 0,05 & 0,04 & 0,06 \\
\hline 12 & Fab. Elem. quimicos nâa-petroq.e quim.diversos & $-0,13$ & 0,10 & 0,06 & 0,06 & 0,09 & 0,38 & 0,41 & 0,42 & 0,30 & 0,22 \\
\hline 13 & Refino de petróleo e indústria petroquimica & $-0,11$ & $-0,29$ & $-0,15$ & $-0,09$ & $-0,14$ & 0,19 & 0,13 & 0,14 & 0,15 & 0,16 \\
\hline 14 & Fab. de produtos farmacêuticos e de perfumaria & 0,52 & 0,54 & 0,51 & 0,51 & 0,48 & 0,60 & 0,59 & 0,57 & 0,59 & 0,63 \\
\hline 15 & Indústria de transformaçăo de material plástico & $-0,10$ & $-0,09$ & $-0,10$ & $-0,07$ & $-0,10$ & 0,09 & 0,08 & 0,08 & 0,07 & 0,05 \\
\hline 16 & Indústria têxill & 0,23 & 0,26 & 0,25 & 0,16 & 0,16 & 0,25 & 0,22 & 0,22 & 0,23 & 0,26 \\
\hline 17 & Fabricaçăo de artigos do vestuáríe e acessórios & 1,29 & 1,13 & 0,99 & 0,95 & 0,93 & 0,85 & 0,83 & 0,63 & 0,62 & 0,63 \\
\hline 18 & Fab. de calçados e de artigos de couro e peles & 0,53 & 0,48 & 0,46 & 0,47 & 0,40 & 0,35 & 0,34 & 0,28 & 0,25 & 0,26 \\
\hline 19 & Indústria de alimentos em geral & 4,02 & 4,22 & 4,38 & 4,21 & 4,46 & 5,15 & 5,39 & 5,17 & 5,23 & 5,28 \\
\hline 20 & Indústrias diversas & 0,09 & 0,11 & 0,11 & 0,09 & 0,09 & 0,20 & 0,21 & 0,23 & 0,24 & 0,24 \\
\hline 21 & Serviços industriais de utilidade publica & 0,26 & 0,38 & 0,41 & 0,25 & 0,21 & 0,18 & 0,19 & 0,20 & 0,22 & 0,23 \\
\hline 22 & Construçẫo civil & 6,56 & 5,95 & 5,63 & 5,43 & 5,49 & 3,96 & 4,00 & 4,50 & 4,50 & 4,28 \\
\hline 23 & Comércio & 3,61 & 3,44 & 3,61 & 3,85 & 3,38 & 2,14 & 2,45 & 2,38 & 2,55 & 2,79 \\
\hline 24 & Transporte & 1,87 & 1,71 & 1,83 & 1,72 & 1,68 & 0,96 & 0,99 & 1,06 & 1,08 & 1,22 \\
\hline 25 & Comunicaçöes & 0,07 & 0,11 & 0,10 & 0,14 & 0,11 & 0,09 & 0,14 & 0,18 & 0,22 & 0,25 \\
\hline 26 & Instituiçōes financeiras & 1,10 & 1,25 & 1,39 & 1,52 & 1,40 & 1,11 & 1,14 & 1,07 & 1,19 & 1,10 \\
\hline 27 & Senvicos prestados às familias & 3,65 & 3,71 & 3,73 & 3,58 & 3,65 & 2,84 & 2,91 & 2,94 & 2,90 & 2,88 \\
\hline 28 & Serviços prestados às empresas & 0,02 & 0,02 & 0,00 & 0,01 & 0,02 & 0,09 & 0,09 & 0,08 & 0,12 & 0,15 \\
\hline 29 & Aluguel de imóveis & 0,45 & 0,45 & 0,44 & 0,40 & 0,41 & 0,40 & 0,41 & 0,42 & 0,43 & 0,42 \\
\hline 30 & Administraçāo pública & 3,71 & 4,16 & 3,96 & 4,35 & 4,33 & 4,80 & 4,10 & 4,26 & 4,44 & 4,11 \\
\hline 31 & Serviços privados não-mercantis & 0,08 & 0,09 & 0,09 & 0,10 & 0,10 & 0,08 & 0,08 & 0,07 & 0,07 & 0,07 \\
\hline
\end{tabular}




\begin{tabular}{|c|c|c|c|c|c|c|c|c|c|c|c|}
\hline & Setor & 1990 & 1991 & 1992 & 1993 & 1994 & 1995 & 1996 & 1997 & 1998 & 1999 \\
\hline 1 & Agropecuária & 2,89 & 3,09 & 3,11 & 3,22 & 3,71 & 3,80 & 3,89 & 3,65 & 3,71 & 3,47 \\
\hline 2 & Extrativa mineral (exceto combustiveis) & 0,35 & 0,32 & 0,31 & 0,30 & 0,30 & 0,26 & 0,25 & 0,24 & 0,23 & 0,23 \\
\hline 3 & Ext.de pertrileo e gás natural, carvão o ourtos comb. & 1,02 & 0,97 & 0,92 & 0,70 & 0,68 & 0,36 & 0,44 & 0,43 & 0,34 & 0,72 \\
\hline 4 & Fabricąăo de minerais não-metalilicos & 1,54 & 1,52 & 1,43 & 1,38 & 1,49 & 1,08 & 1,00 & 1,07 & 1,10 & 1,01 \\
\hline 5 & Siderurgia, met r̂́-ferrososs e out.prod.metaturgricos & 3,45 & 3,19 & 3,11 & 3,09 & 3,24 & 2,91 & 2,74 & 2,84 & 2,63 & 2,53 \\
\hline 6 & Fabricaçăo e manutenção de máquinas e tratores & 1,04 & 0,97 & 1,06 & 1,03 & 0,90 & 0,85 & 0,85 & 0,65 & 0,63 & 0,61 \\
\hline 7 & Fab.de ap.e equip.de mat.elétrico eletrônico & 0,82 & 0,75 & 0,73 & 0,69 & 0,64 & 0,44 & 0,40 & 0,38 & 0,36 & 0,32 \\
\hline 8 & Fab.auto.cam.onib.out.veic,. peças e acessórios & 0,99 & 0,88 & 0,91 & 0,86 & 0,84 & 0,57 & 0,52 & 0,57 & 0,50 & 0,42 \\
\hline 9 & Serraras e tab. de artigos de madeira e mobiliário & 0,44 & 0,39 & 0,34 & 0,35 & 0,38 & 0,34 & 0,32 & 0,29 & 0,28 & 0,27 \\
\hline 10 & Indústria de papel e gráfica & 1,18 & 1,33 & 1,19 & 1,08 & 1,08 & 1,11 & 1,11 & 1,03 & 1,00 & 1,08 \\
\hline 11 & Indústria da borracha & 0,62 & 0,60 & 0,60 & 0,59 & 0,60 & 0,46 & 0,42 & 0,41 & 0,37 & 0,37 \\
\hline 12 & Fab. Elem. químicos não-petroq.e quím.diversos & 1,99 & 1,97 & 1,95 & 1,95 & 1,88 & 1,56 & 1,58 & 1,65 & 1,68 & 1,88 \\
\hline 13 & Refino de pertoleo e indisstria pertoquuirica & 3,20 & 3,27 & 3,55 & 3,73 & 3,39 & 2,76 & 2,82 & 2,88 & 2,96 & 3,56 \\
\hline 14 & Fab. de produtos farmacêuticos e de perfumaria & 0,20 & 0,18 & 0,21 & 0,21 & 0,21 & 0,08 & 0,09 & 0,14 & 0,15 & 0,14 \\
\hline 15 & Indústria de transtormaçāo de material plástico & 0,69 & 0,65 & 0,60 & 0,62 & 0,59 & 0,54 & 0,59 & 0,57 & 0,53 & 0,50 \\
\hline 16 & Indusstria texxil & 1,20 & 1,08 & 0,97 & 0,98 & 0,96 & 0,85 & 0,82 & 0,68 & 0,67 & 0,67 \\
\hline 17 & Fabricaçăo de artigos do vestuário e acessórios & 0,04 & 0,04 & 0,04 & 0,02 & 0,02 & 0,02 & 0,02 & 0,01 & 0,01 & 0,01 \\
\hline 18 & Fab. de calcadoso e de artigos de couro e peles & 0,05 & 0,05 & 0,04 & 0,03 & 0,03 & 0,03 & 0,03 & 0,03 & 0,02 & 0,02 \\
\hline 19 & Indústria de alimentos em geral & $\begin{array}{l}0,030 \\
1,27\end{array}$ & $\begin{array}{l}0,30 \\
1,39\end{array}$ & $\begin{array}{l}0,34 \\
1,35\end{array}$ & $\begin{array}{l}0,35 \\
1,35\end{array}$ & $\begin{array}{l}0,03 \\
1,41\end{array}$ & $\begin{array}{l}0,03 \\
1,15\end{array}$ & $\begin{array}{l}1,15 \\
1,15\end{array}$ & $\begin{array}{l}0,030 \\
1,10\end{array}$ & $\begin{array}{l}0,062 \\
1,07\end{array}$ & $\begin{array}{l}1,08 \\
1,08\end{array}$ \\
\hline 20 & Industrtias diversas & $\begin{array}{l}1,17 \\
0,39\end{array}$ & $\begin{array}{l}1,393 \\
0,38\end{array}$ & $\begin{array}{l}1,33 \\
0,37\end{array}$ & $\begin{array}{l}1,330 \\
0,41\end{array}$ & 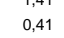 & 0,30 & $\begin{array}{l}1,15 \\
0,28\end{array}$ & $\begin{array}{l}1,23 \\
0,23\end{array}$ & 0,23 & 0,23 \\
\hline 21 & Serviços industriais de utilidade pública & 1,29 & 1,57 & 1,66 & 1,46 & 1,46 & 1,33 & 1,34 & 1,30 & 1,58 & 1,57 \\
\hline 22 & Construção civil & 0,34 & 0,34 & 0,33 & 0,34 & 0,37 & 0,47 & 0,45 & 0,45 & 0,46 & 0,43 \\
\hline 23 & Comércio & 0,76 & 0,79 & 0,81 & 0,89 & 0,81 & 2,51 & 2,40 & 2,84 & 2,78 & 2,66 \\
\hline 24 & Transporte & 0,83 & 0,82 & 0,83 & 0,87 & 0,88 & 1,54 & 1,48 & 1,44 & 1,48 & 1,43 \\
\hline 25 & Comunicaă̄oes & 0,41 & 0,45 & 0,49 & 0,52 & 0,48 & 0,49 & 0,62 & 0,65 & 0,82 & 0,89 \\
\hline 26 & Instituiç̄eses financeiras & 0,68 & 0,49 & 0,52 & 0,47 & 0,55 & 0,78 & 0,88 & 0,96 & 0,85 & 0,87 \\
\hline 27 & Serviços prestados às familias & 0,96 & 0,98 & 0,98 & 1,02 & 0,97 & 1,18 & 1,08 & 1,00 & 0,97 & 0,88 \\
\hline 28 & Servicos prestados às empresas & 1,50 & 1,87 & 1,95 & 2,03 & 1,86 & 2,02 & 2,33 & 2,39 & 2,47 & 2,21 \\
\hline 29 & Aluguel de imóveis & 0,32 & 0,34 & 0,33 & 0,33 & 0,38 & 0,65 & 0,63 & 0,63 & 0,62 & 0,53 \\
\hline 30 & Administraçăo püblica & 0,57 & 0,33 & 0,33 & 0,45 & 0,47 & 0,56 & 0,50 & 0,48 & 0,50 & 0,41 \\
\hline 31 & Servicos privados náo-mercantis & 0,00 & 0,00 & 0,00 & 0,00 & 0,00 & 0,00 & 0,00 & 0,00 & $\begin{array}{l}0,00 \\
0,0\end{array}$ & $\begin{array}{l}0,41 \\
0,00\end{array}$ \\
\hline
\end{tabular}




\begin{tabular}{|c|c|c|c|c|c|c|c|c|c|c|c|}
\hline & Setor & 1990 & 1991 & 1992 & 1993 & 1994 & 1995 & 1996 & 1997 & 1998 & 1999 \\
\hline 1 & Agropecuária & 1,90 & 1,98 & 2,00 & 1,96 & 2,28 & 2,40 & 2,43 & 2,32 & 2,36 & 2,37 \\
\hline 2 & Extrativa mineral (exceto combustiveis) & 0,23 & 0,25 & 0,25 & 0,22 & 0,21 & 0,22 & 0,22 & 0,20 & 0,20 & 0,20 \\
\hline 3 & Ext.de pertróleo e gás natural, carvão e outros comb. & 0,35 & 0,32 & 0,30 & 0,22 & 0,20 & 0,18 & 0,22 & 0,22 & 0,17 & 0,36 \\
\hline 4 & Fabricaçăo de minerais não-metálicos & 0,58 & 0,61 & 0,57 & 0,56 & 0,59 & 0,58 & 0,55 & 0,58 & 0,59 & 0,54 \\
\hline 5 & Siderurgia, met $\hat{f}$-errososos e out.prod.metalurgicos & 1,71 & 1,68 & 1,69 & 1,64 & 1,69 & 1,70 & 1,62 & 1,65 & 1,54 & 1,51 \\
\hline 6 & Fabricacăó e manutençăo de máquinas etratores & 0.81 & 0,70 & 0,75 & 0,76 & 0,78 & 0,75 & 0,72 & 0,67 & 0,63 & 0,61 \\
\hline 7 & Fab.de ap.e equip.de matelétrico eletrônico & 0.87 & 0.78 & 0.71 & 0.71 & 0.76 & 0,85 & 0,83 & 0,75 & 0.68 & 0,61 \\
\hline 8 & Fab.auto.cam.onib.out.veic,. pecas e acessórios & 1,05 & 0.98 & 0,98 & 1.05 & ${ }_{1,11}>>1$ & 1,19 & 1,17 & 1,18 & 1,00 & 0,92 \\
\hline 9 & Serrarasas e tab. de artigos de madeira e mobiliário & 0.42 & 0,38 & 0,36 & 0.37 & 0,38 & 0,40 & 0,41 & 0,38 & 0,35 & 0,36 \\
\hline 10 & Indústria de papel e gráíca & 0,64 & 0.72 & 0,65 & 0.59 & 0.59 & 0,70 & 0,69 & 0,64 & 0.63 & 0,68 \\
\hline 11 & Indústria da borracha & 0,22 & 0,22 & 0,23 & 0,24 & 0,24 & 0,25 & 0,23 & 0,23 & 0,20 & 0,21 \\
\hline 12 & Fab. Elem. quimicos não-petroq.e quím.diversos & 0,92 & 1,03 & 1,00 & 1,00 & 0,98 & 0,97 & 1,00 & 1,03 & 0,99 & 1,05 \\
\hline 13 & Refino de petroleo e indústria pertoquímica & 1,53 & 1,48 & 1,69 & 1,81 & 1,62 & 1,47 & 1,47 & 1,51 & 1,55 & 1,85 \\
\hline 14 & Fab. de produtos farmacêuticos e de pertumaria & 0,36 & 0,37 & 0,36 & 0,36 & 0,35 & 0,34 & 0,34 & 0,36 & 0,37 & 0,39 \\
\hline 15 & Indústria de transtormaąăo de material plástico & 0,29 & 0,28 & 0,25 & 0,27 & 0,25 & 0,31 & 0,33 & 0,32 & 0,30 & 0,28 \\
\hline 16 & Indústria têxtil & 0,71 & 0,67 & 0,61 & 0,57 & 0,56 & 0,55 & 0,52 & 0,45 & 0,45 & 0,46 \\
\hline 17 & Fabricaçăo de artigos do vestuário e acessororios & 0,67 & 0,59 & 0,52 & 0,49 & 0,48 & 0,44 & 0,43 & 0,32 & 0,32 & 0,32 \\
\hline 18 & Fab. de calcados e de artigos de couro e peles & 0,29 & 0,27 & 0,25 & 0,25 & 0,22 & 0,19 & 0,18 & 0,15 & 0,14 & 0,14 \\
\hline 19 & Indústria de alimentos em geral & 2,65 & 2,81 & 2,87 & 2,79 & 2,94 & 3,16 & 3,27 & 3,14 & 3,16 & 3,18 \\
\hline 20 & Indústrias diversas & 0,24 & 0,24 & 0,24 & 0,25 & 0,25 & 0,25 & 0,24 & 0,23 & 0,23 & 0,24 \\
\hline 21 & Servicoss industriais de utilidade pública & 0,77 & 0,97 & 1,03 & 0,85 & 0,83 & 0,75 & 0,76 & 0,75 & 0,90 & 0,90 \\
\hline 22 & Construçăo civil & 3,47 & 3,16 & 3,00 & 2,90 & 2,94 & 2,22 & 2,23 & 2,48 & 2,48 & 2,36 \\
\hline 23 & Comério & 2,19 & 2,12 & 2,22 & 2,38 & 2,10 & 2,33 & 2,42 & 2,61 & 2,66 & 2,73 \\
\hline 24 & Transporte & 1,35 & 1,27 & 1,33 & 1,30 & 1,28 & 1,25 & 1,23 & 1,25 & 1,28 & 1,32 \\
\hline 25 & Comunicą̧⿻上丨es & 0,24 & 0,28 & 0,29 & 0,33 & 0,29 & 0,29 & 0,38 & 0,41 & 0,52 & 0,57 \\
\hline 26 & Instituiç̄ês financeiras & 0,89 & 0,87 & 0,96 & 1,00 & 0,98 & 0,95 & 1,01 & 1,01 & 1,02 & 0,99 \\
\hline 27 & Servicos prestados às familias & 2,31 & 2,35 & 2,36 & 2,31 & 2,32 & 2,01 & 2,00 & 1,97 & 1,94 & \\
\hline 28 & Servicos prestados às empresas & 0,75 & 0,94 & 0,97 & ${ }^{1,02}$ & 0,93 & 1,05 & 1,21 & 1,23 & 1,29 & 1,18 \\
\hline 29 & Aluguel de imóveis & 0,38 & 0,40 & 0,38 & 0,37 & 0,40 & 0,52 & 0,52 & 0,52 & 0,52 & \\
\hline 30 & Administraçăo púbilica & 2,15 & 2,26 & 2,15 & 2,41 & 2,41 & 2,69 & 2,30 & 2,38 & 2,47 & 26 \\
\hline & Servicos privados não-mercantis & 0,04 & 0,04 & & & & & 0,04 & & & \\
\hline
\end{tabular}


ANEXO M - Multiplicadores de emprego do tipo I.

\begin{tabular}{|c|c|c|c|c|c|c|c|c|c|c|c|}
\hline & Setor & 1990 & 1991 & 1992 & 1993 & 1994 & 1995 & 1996 & 1997 & 1998 & 1999 \\
\hline 1 & Agropecuária & 1,33 & 1,33 & 1,35 & 1,34 & 1,32 & 1,27 & 1,29 & 1,28 & 1,29 & $\overline{1,30}$ \\
\hline 2 & Extrativa mineral (exceto combustiveis) & 2,00 & 1,82 & 1,81 & 1,93 & 2,07 & 2,10 & 2,33 & 2,27 & 1,96 & 1,87 \\
\hline 3 & Ext.de petrolleo e gás natural, carvâo e outros comb. & 5,98 & 6,16 & 6,80 & 7,53 & 8,16 & 7,57 & 7,85 & 8,68 & 11,67 & 4,99 \\
\hline 4 & Fabricaçăo de minerais não-metálicos & 2,33 & 2,22 & 2,23 & 2,17 & 2,10 & 2,05 & 2,15 & 1,97 & 2,01 & 1,99 \\
\hline 5 & Siderurgia, met ñ-ferrosos e out.prod.metalurgicos & 4,26 & 3,80 & 3,99 & 3,96 & 4,16 & 3,54 & 3,64 & 3,55 & 3,31 & 3,42 \\
\hline 6 & Fabricaçăo e manutençăo de máquinas e tratores & 2,90 & 2,77 & 2,47 & 2,22 & 2,49 & 2,16 & 2,13 & 2,10 & 2,12 & 2,06 \\
\hline 7 & Fab.de ap.e equip.de matelelétrico eletrônico & 3,04 & 3,15 & 3,12 & 3,36 & 3,62 & 3,05 & 3,36 & 3,52 & 3,35 & 3,61 \\
\hline 8 & Fab.auto.cam.onib.out.veic., peças e acessórios & 4,32 & 4,27 & 4,40 & 4,33 & 4,45 & 3,82 & 4,18 & 4,55 & 4,61 & 4,25 \\
\hline 9 & Serrarias e fab. de artigos de madeira e mobiliärio & 2,24 & 2,03 & 2,17 & 2,06 & 2,12 & 1,96 & 1,97 & 1,91 & 1,90 & 1,85 \\
\hline 10 & Indústria de papel e gráfica & 3,41 & 3,01 & 3,44 & 4,25 & 4,13 & 2,99 & 3,15 & 3,17 & 3,19 & 2,98 \\
\hline 11 & Indústria da borracha & 5,60 & 5,63 & 5,51 & 5,54 & 6,29 & 5,05 & 5,79 & 6,08 & 5,30 & 5,38 \\
\hline 12 & Fab. Elem. quimicos năo-petroq.e quim.diversos & 8,14 & 8,43 & 8,49 & 7,47 & 9,59 & 7,79 & 8,16 & 8,00 & 7,15 & 6,35 \\
\hline 13 & Refino de petróleo e indústria petroquímica & 20,87 & 27,01 & 18,95 & 10,16 & 13,74 & 11,83 & 14,57 & 15,35 & 18,98 & 19,41 \\
\hline 14 & Fab. de produtos farmacêuticos e de perfumaria & 6,30 & 8,03 & 5,40 & 4,51 & 4,86 & 4,15 & 4,01 & 3,92 & 4,14 & 4,48 \\
\hline 15 & Indústria de transformaçăo de material plástico & 2,12 & 2,29 & 2,25 & 1,92 & 2,12 & 1,87 & 1,85 & 1,85 & 1,75 & 1,71 \\
\hline 16 & Indústria têxtil & 3,36 & 3,85 & 3,73 & 3,30 & 4,01 & 3,27 & 3,47 & 3,48 & 3,98 & 4,20 \\
\hline 17 & Fabricaçăo de artigos do vestuário e acessórios & 1,29 & 1,29 & 1,26 & 1,24 & 1,24 & 1,19 & 1,18 & 1,17 & 1,18 & 1,19 \\
\hline 18 & Fab. de calçados e de artigos de couro e peles & 2,24 & 2,07 & 1,80 & 1,84 & 1,93 & 1,77 & 1,76 & 1,70 & 1,65 & 1,60 \\
\hline 19 & Industria de alimentos em geral & 11,60 & 10,69 & 9,58 & 9,66 & 10,72 & 9,75 & 9,44 & 8,68 & 7,47 & 7,81 \\
\hline 20 & Indústrias diversas & 1,75 & 1,72 & 1,69 & 1,63 & 1,66 & 1,69 & 1,82 & 1,75 & 1,81 & 1,80 \\
\hline 21 & Senvicos industriais de utilidade püblica & 3,35 & 4,54 & 4,24 & 3,04 & 3,02 & 2,31 & 2,37 & 2,56 & 2,85 & 2,97 \\
\hline 22 & Construção civil & 2,35 & 2,29 & 2,11 & 1,97 & 1,94 & 1,65 & 1,58 & 1,60 & 1,53 & 1,56 \\
\hline 23 & Comércio & 1,21 & 1,21 & 1,23 & 1,23 & 1,20 & 1,17 & 1,21 & 1,22 & 1,20 & 1,19 \\
\hline 24 & Transporte & 1,61 & 1,54 & 1,59 & 1,57 & 1,57 & 1,38 & 1,45 & 1,45 & 1,44 & 1,48 \\
\hline 25 & Comunicaçöes & 1,55 & 2,13 & 1,69 & 1,78 & 1,85 & 1,54 & 1,70 & 1,86 & 2,46 & 2,28 \\
\hline 26 & Instituiçōes financeiras & 1,60 & 1,80 & 1,48 & 1,38 & 1,75 & 2,11 & 2,44 & 2,57 & 2,71 & 2,76 \\
\hline 27 & Senicos prestados às familias & 1,49 & 1,46 & 1,44 & 1,43 & 1,46 & 1,28 & 1,23 & 1,23 & 1,22 & 1,24 \\
\hline 28 & Serviços prestados às empresas & 1,33 & 1,27 & 1,28 & 1,30 & 1,33 & 1,25 & 1,23 & 1,22 & 1,22 & 1,25 \\
\hline 29 & Aluguel de imóveis & 2,91 & 1,95 & 2,38 & 3,11 & 2,94 & 1,94 & 1,70 & 1,67 & 1,76 & 1,76 \\
\hline 30 & Administraçăo pública & 1,61 & 1,70 & 1,69 & 1,83 & 1,81 & 1,79 & 1,63 & 1,66 & 1,63 & 1,61 \\
\hline 31 & Servicos privados năo-mercantis & 1,02 & 1,02 & 1,02 & 1,02 & 1,02 & 1,01 & 1,01 & 1,01 & 1,01 & 1,01 \\
\hline
\end{tabular}


ANEXO N - Multiplicadores de emprego do tipo II.

\begin{tabular}{|c|c|c|c|c|c|c|c|c|c|c|c|}
\hline & 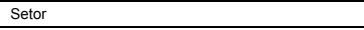 & 1990 & 1991 & 1992 & 1993 & 1994 & 1995 & 1996 & 1997 & 1998 & 1999 \\
\hline 1 & Agropecuária & 1,75 & 1,85 & 1,82 & 1,73 & 1,80 & 1,73 & 1,85 & 1,82 & 1,85 & 1,84 \\
\hline 2 & Extrativa mineral (exceto combustiveis) & 5,40 & 5,01 & 4,45 & 4,66 & 6,09 & 5,58 & 6,72 & 6,38 & 4,76 & 4,77 \\
\hline 3 & Ext.de petróleo e gás natural, carvão e outros comb. & 22,08 & 27,80 & 26,56 & 27,25 & 39,16 & 33,61 & 39,48 & 42,84 & 43,21 & 27,39 \\
\hline 4 & Fabricaçăo de minerais näo-metálicos & 5,77 & 5,92 & 5,43 & 4,98 & 5,67 & 5,15 & 5,81 & 5,13 & 5,06 & 4,95 \\
\hline 5 & Siderurgia, met ñ-ferrosos e out.prod.metalurgicos & 11,99 & 11,86 & 11,06 & 10,56 & 13,10 & 9,72 & 10,66 & 10,10 & 8,59 & 8,80 \\
\hline 6 & Fabricação e manutenção de máquinas e tratores & 9,36 & 10,06 & 7,93 & 6,60 & 9,46 & 7,36 & 7,62 & 7,37 & 6,95 & 6,94 \\
\hline 7 & Fab.de ap.e equip.de mat.elétrico eletrônico & 8,45 & 9,84 & 8,75 & 9,12 & 12,19 & 9,12 & 10,81 & 10,92 & 9,86 & 10,48 \\
\hline 8 & Fab.auto.cam.onib.out.veic., peças e acessórios & 13,11 & 15,31 & 14,26 & 12,77 & 15,81 & 11,79 & 13,87 & 14,27 & 13,69 & 12,29 \\
\hline 9 & Serrarias e fab. de artigos de madeira e mobiliärio & 4,22 & 3,91 & 3,97 & 3,53 & 3,88 & 3,30 & 3,47 & 3,34 & 3,34 & 3,21 \\
\hline 10 & Indústria de papel e gráfica & 9,62 & 8,52 & 9,21 & 11,47 & 12,45 & 7,46 & 8,34 & 8,32 & 8,02 & 7,44 \\
\hline 11 & Indústria da borracha & 15,18 & 17,54 & 15,39 & 13,99 & 18,70 & 14,09 & 17,72 & 17,95 & 14,49 & 14,43 \\
\hline 12 & Fab. Elem. quimicos não-petroq.e quim.diversos & 20,38 & 22,55 & 20,60 & 16,80 & 24,61 & 19,73 & 21,84 & 21,00 & 17,90 & 17,38 \\
\hline 13 & Refino de petróleo e indústria petroquimica & 75,04 & 116,91 & 73,98 & 39,10 & 71,21 & 61,81 & 78,94 & 79,53 & 94,10 & 100,67 \\
\hline 14 & Fab. de produtos farmacêuticos e de perfumaria & 17,74 & 24,45 & 15,07 & 11,76 & 14,99 & 12,19 & 12,47 & 12,14 & 12,54 & 13,26 \\
\hline 15 & Indüstria de transformaçăo de material plástico & 6,27 & 7,76 & 6,93 & 5,44 & 7,63 & 5,97 & 6,19 & 5,97 & 5,05 & 4,68 \\
\hline 16 & Industria têxtil & 6,94 & 8,93 & 8,20 & 6,81 & 9,43 & 7,07 & 8,18 & 7,95 & 8,85 & 8,79 \\
\hline 17 & Fabricaçăo de artigos do vestuário e acessórios & 2,06 & 2,15 & 1,95 & 1,87 & 2,02 & 1,70 & 1,69 & 1,65 & 1,70 & 1,69 \\
\hline 18 & Fab. de calçados e de artigos de couro e peles & 4,60 & 4,26 & 3,30 & 3,24 & 3,91 & 3,20 & 3,33 & 3,16 & 2,93 & 2,84 \\
\hline 19 & Indústria de alimentos em geral & 19,00 & 18,50 & 15,82 & 14,85 & 17,74 & 15,99 & 16,45 & 15,02 & 12,86 & 13,27 \\
\hline 20 & Indústrias diversas & 4,06 & 4,26 & 3,80 & 3,34 & 4,01 & 3,76 & 4,39 & 4,12 & 4,08 & 3,91 \\
\hline 21 & Senvicos industriais de utilidade püblica & 15,87 & 21,17 & 19,03 & 16,77 & 20,69 & 14,22 & 15,77 & 16,85 & 17,75 & 19,12 \\
\hline 22 & Construção civil & 6,13 & 6,54 & 5,36 & 4,52 & 5,20 & 4,03 & 4,06 & 4,08 & 3,54 & 3,69 \\
\hline 23 & Comércio & 2,63 & 2,75 & 2,61 & 2,50 & 2,70 & 2,25 & 2,45 & 2,46 & 2,30 & 2,23 \\
\hline 24 & Transporte & 4,45 & 4,51 & 4,33 & 4,10 & 4,60 & 3,25 & 3,64 & 3,50 & 3,34 & 3,27 \\
\hline 25 & Comunicaăöes & 6,29 & 9,35 & 7,00 & 6,57 & 9,07 & 7,26 & 8,51 & 9,08 & 13,88 & 13,85 \\
\hline 26 & Instituiçöes financeiras & 8,22 & 11,16 & 7,90 & 6,36 & 10,80 & 10,57 & 12,51 & 12,68 & 12,45 & 12,48 \\
\hline 27 & Senvicos prestados às familias & 3,21 & 3,12 & 2,92 & 2,73 & 3,05 & 2,20 & 2,14 & 2,12 & 2,03 & 2,05 \\
\hline 28 & Serviços prestados às empresas & 3,92 & 3,58 & 3,48 & 3,24 & 4,01 & 3,11 & 2,97 & 2,92 & 2,90 & 2,92 \\
\hline 29 & Aluguel de imóveis & 13,60 & 20,19 & 18,30 & 15,98 & 26,22 & 26,05 & 29,00 & 29,84 & 28,07 & 28,62 \\
\hline 30 & Administraçăo pública & 7,12 & 7,05 & 6,48 & 6,78 & 7,95 & 6,00 & 5,58 & 5,58 & 5,24 & 5,18 \\
\hline 31 & Serviços privados não-mercantis & 1,52 & 1,46 & 1,42 & 1,41 & 1,46 & 1,29 & 1,27 & 1,26 & 1,24 & 1,24 \\
\hline
\end{tabular}




\begin{tabular}{|c|c|c|c|c|c|c|c|c|c|c|c|}
\hline & Setor & 1990 & 1991 & 1992 & 1993 & 1994 & 1995 & 1996 & 1997 & 1998 & 1999 \\
\hline 1 & Agropecuária & 271,77 & 292,65 & 269,91 & 257,83 & 275,08 & 256,14 & 237,47 & 232,60 & 196,10 & 210,23 \\
\hline 2 & Extrativa mineral (exceto combustiveis) & 171,24 & 170,47 & 147,53 & 135,79 & 154,86 & 122,85 & 122,98 & 113,00 & 108,54 & 99,48 \\
\hline 3 & Ext.de petróleo e gás natural, carvão e outros comb. & 83.95 & 106.95 & 95,53 & 83.85 & 111,76 & 93.48 & 91,73 & 85,73 & 85.58 & 73.78 > \\
\hline 4 & Fabricação de minerais não-metâlilicos & 153,44 & 158,41 & 141,80 & 122,84 & 141,27 & 118,73 & 121,05 & 109,51 & 97,12 & 98,86 \\
\hline 5 & Siderurgia, met ñ-ferrosos e out.prod.metalurgicos & 160,54 & 164,69 & 141,37 & 121,77 & 140,57 & 109,51 & 112,33 & 103,29 & 96,10 & 90,57 \\
\hline 6 & Fabricąăo e manutençăo de máquinas e tratores & 149,20 & 159,26 & 133,87 & 106,12 & 131,65 & 103,68 & 108,09 & 99,67 & 90,66 & 88,86 \\
\hline 7 & Fab.de ap.e equip.de mat.elétrico eletrônico & 146,60 & 154,80 & 132,34 & 112,44 & 132,50 & 92,28 & 92,91 & 91,63 & 83,50 & 80,17 \\
\hline 8 & Fab.auto.cam.onib.ut.veic., peças e acessórios & 158,70 & 175,15 & 148,60 & 116,97 & 136,52 & 97,44 & 97,69 & 91,27 & 82,54 & 79,56 \\
\hline 9 & Serrarias e fab. de artigos de madeira e mobiliário & 228,43 & 237,37 & 216,28 & 199,80 & 225,87 & 197,36 & 192,55 & 178,34 & 160,41 & 159,17 \\
\hline 10 & Indústria de papel e gráfica & 188,02 & 183,25 & 169,59 & 155,86 & 179,83 & 130,36 & 130,74 & 120,27 & 110,71 & 104,49 \\
\hline 11 & Indústria da borracha & 127,08 & 142,63 & 120,62 & 98,33 & 125,09 & 94,26 & 95,01 & 89,39 & 81,93 & 78,70 \\
\hline 12 & Fab. Elem. quimicos năo-petroq.e quim.diversos & 143,10 & 156,43 & 137,85 & 110,47 & 136,81 & 105,96 & 106,44 & 103,05 & 92,60 & 85,01 \\
\hline 13 & Refino de petróleo e indústria petroquímica & 88,34 & 111,88 & 86,53 & 59,03 & 88,58 & 66,51 & 69,99 & 68,15 & 61,42 & 60,08 \\
\hline 14 & Fab. de produtos farmacêuticos e de perfumaria & 137,20 & 159,32 & 130,63 & 109,75 & 136,18 & 101,99 & 102,91 & 100,87 & 89,12 & 87,63 \\
\hline 15 & Indústria de transformação de material plastico & 124,96 & 140,36 & 122,19 & 99,23 & 124,16 & 95,30 & 99,32 & 94,66 & 88,49 & 91,21 \\
\hline 16 & Indústria têxtil & 149,45 & 173,40 & 152,31 & 129,08 & 157,37 & 115,72 & 109,57 & 105,99 & 96,12 & 98,36 \\
\hline 17 & Fabricaăăo de artigos do vestuário e acessórios & 312,70 & 343,09 & 325,32 & 310,77 & 337,58 & 283,53 & 277,61 & 263,66 & 228,57 & 234,21 \\
\hline 18 & Fab. de calcados e de artigos de couro e peles & 227,49 & 236,64 & 210,53 & 186,83 & 218,03 & 168,74 & 165,13 & 156,23 & 147,44 & 142,76 \\
\hline 19 & Industria de alimentos em geral & 212,24 & 225,67 & 202,52 & 188,75 & 212,59 & 178,79 & 171,38 & 160,39 & 140,48 & 143,69 \\
\hline 20 & Industrtras diversas & 170,64 & 183,53 & 168,71 & 149,65 & 168,60 & 145,35 & 135,68 & 127,18 & 115,35 & 113,54 \\
\hline 21 & Servicos industriais de utilidade pública & 150,16 & 157,76 & 141,10 & 136,43 & 152,68 & 97,37 & 95,08 & 95,36 & 79,39 & 77,43 \\
\hline 22 & Construçăo civil & 153,49 & 161,37 & 139,45 & 119,93 & 134,38 & 108,83 & 110,45 & 108,59 & 101,66 & 102,57 \\
\hline 23 & Comércio & 233,86 & 249,60 & 232,49 & 207,71 & 233,13 & 188,48 & 183,62 & 175,46 & 167,52 & 166,65 \\
\hline 24 & Transporte & 201,59 & 213,49 & 184,29 & 163,93 & 187,76 & 138,26 & 142,19 & 143,46 & 133,01 & 128,23 \\
\hline 25 & Comunicaçöes & 153,49 & 160,63 & 133,47 & 113,56 & 142,13 & 100,43 & 99,04 & $\begin{array}{r}44,40 \\
94,54\end{array}$ & 81,85 & $\begin{array}{r}81,80 \\
81,88\end{array}$ \\
\hline 26 & Instituiçöes financeiras & 110,11 & 140,72 & 105,03 & 88,79 & 135,38 & 120,90 & 124,62 & 120,06 & 105,79 & 107,54 \\
\hline 27 & Servicos prestados às familias & 269,30 & 274,65 & 251,43 & 230,72 & 258,64 & 212,49 & 212,27 & 209,19 & 200,27 & 206,03 \\
\hline 28 & Serviços prestados às empresas & 206,03 & 199,66 & 191,49 & 168,32 & 204,49 & 160,92 & 160,53 & 156,69 & 143,25 & 143,52 \\
\hline 29 & Aluguel de imóveis & 39,31 & 52,44 & 40,81 & 32,36 & 56,36 & 63,54 & 68,10 & 66,22 & 56,47 & 62,05 \\
\hline 30 & Administraçăo púbica & $\begin{array}{l}250,84 \\
250,19\end{array}$ & $\begin{array}{r}324,44 \\
244,46\end{array}$ & $\begin{array}{r}428,56 \\
2286\end{array}$ & 211,74 & 240,43 & $\begin{array}{l}0,04 \\
165,98\end{array}$ & 163,27 & $\begin{array}{l}0,22 \\
157,06\end{array}$ & $\begin{array}{l}14,41 \\
14407\end{array}$ & 146,23 \\
\hline 31 & Serviços privados não-mercantis & 620,98 & 657,62 & 640,22 & 631,81 & 659,94 & 600,27 & 610,02 & 603,80 & 582,12 & 599,03 \\
\hline
\end{tabular}




\begin{tabular}{|c|c|c|c|c|c|c|c|c|c|c|c|}
\hline & Setor & 1990 & 1991 & 1992 & 1993 & 1994 & 1995 & 1996 & 1997 & 1998 & 1999 \\
\hline 1 & Agropecuária & 155,18 & 158,17 & 148,44 & 148,74 & 153,00 & 148,23 & 128,25 & 127,70 & 105,77 & 114,28 \\
\hline 2 & Extrativa mineral (exceto combustiveis) & 31,74 & 34,04 & 33,15 & 29,16 & 25,42 & 22,01 & 18,29 & 17,70 & 22,83 & 20,84 \\
\hline 3 & Ext.de petróleo e gás natural, carvão e outros comb. & 3.80 & 3.85 & 3.60 & 3.08 & 2.85 & 2.78 & 2.32 & 2.00 & 1.98 & 2.69 \\
\hline 4 & Fabricaçăo de minerais näo-metâlicos & 26,59 & 26,76 & 26,10 & 24,65 & 24,91 & 23,07 & 20,83 & 21,33 & 19,20 & 19,98 \\
\hline 5 & Siderurgia, met ñ-ferrosos e out.prod.metalurgicos & 13,38 & 13,88 & 12,78 & 11,54 & 10,73 & 11,26 & 10,54 & 10,23 & 11,18 & 10,29 \\
\hline 6 & Fabricąăo e manutençăo de máquinas e tratores & 15,94 & 15,82 & 16,89 & 16,07 & 13,92 & 14,08 & 14,18 & 13,52 & 13,05 & 12,80 \\
\hline 7 & Fab.de ap.e equip.de mat.elétrico eletrônico & 17,35 & 15,73 & 15,13 & 12,33 & 10,87 & 10,12 & 8,60 & 8,39 & 8,47 & 7,65 \\
\hline 8 & Fab.auto.cam.onib.ut.veic., peças e acessórios & 12,11 & 11,44 & 10,42 & 9,16 & 8,63 & 8,26 & 7,04 & 6,40 & 6,03 & 6,47 \\
\hline 9 & Serrarias e fab. de artigos de madeira e mobiliário & 54,13 & 60,71 & 54,42 & 56,61 & 58,25 & 59,82 & 55,45 & 53,47 & 48,08 & 49,53 \\
\hline 10 & Indústria de papel e gráfica & 19,54 & 21,50 & 18,42 & 13,58 & 14,45 & 17,46 & 15,68 & 14,46 & 13,81 & 14,04 \\
\hline 11 & Indústria da borracha & 8,37 & 8,13 & 7,84 & 7,03 & 6,69 & 6,69 & 5,36 & 4,98 & 5,65 & 5,46 \\
\hline 12 & Fab. Elem. quimicos nāo-petroq.e quim.diversos & 7,02 & 6,94 & 6,69 & 6,57 & 5,56 & 5,37 & 4,87 & 4,91 & 5,17 & 4,89 \\
\hline 13 & Refino de petróleo e indústria petroquímica & 1,18 & 0,96 & 1,17 & 1,51 & 1,24 & 1,08 & 0,89 & 0,86 & 0,65 & 0,60 \\
\hline 14 & Fab. de produtos farmacêuticos e de perfumaria & 7,73 & 6,52 & 8,67 & 9,34 & 9,09 & 8,37 & 8,25 & 8,31 & 7,11 & 6,61 \\
\hline 15 & Indüstria de transformaçăo de material plástico & 19,92 & 18,08 & 17,64 & 18,23 & 16,27 & 15,96 & 16,06 & 15,85 & 17,52 & 19,51 \\
\hline 16 & Indüstria texxil & 21,54 & 19,41 & 18,57 & 18,95 & 16,68 & 16,36 & 13,40 & 13,33 & 10,86 & 11,19 \\
\hline 17 & Fabricaăăo de artigos do vestuário e acessórios & 151,45 & 159,78 & 166,54 & 166,22 & 167,33 & 166,97 & 164,44 & 159,90 & 134,58 & 138,54 \\
\hline 18 & Fab. de calçados e de artigos de couro e peles & 49,46 & 55,53 & 63,70 & 57,59 & 55,81 & 52,71 & 49,54 & 49,48 & 50,28 & 50,25 \\
\hline 19 & Industria de alimentos em geral & 11,17 & 12,20 & 12,80 & 12,71 & 11,99 & 11,18 & 10,42 & 10,68 & 10,92 & 10,83 \\
\hline 20 & Indústrias diversas & 41,99 & 43,11 & 44,40 & 44,81 & 42,04 & 38,69 & 30,87 & 30,88 & 28,30 & 29,04 \\
\hline 21 & Servicos industriais de uttilidade publica & 9,46 & 7,45 & 7,41 & 8,13 & 7,38 & 6,85 & 6,03 & 5,66 & 4,47 & 4,05 \\
\hline 22 & Construçăo civil & 25,03 & 24,67 & 26,01 & 26,54 & 25,82 & 27,02 & 27,21 & 26,63 & 28,73 & 27,82 \\
\hline 23 & Comércio & 88,79 & 90,90 & 89,04 & 83,06 & 86,44 & 83,68 & 74,84 & 71,25 & 72,73 & 74,71 \\
\hline 24 & Transporte & 45,27 & 47,36 & 42,56 & 39,95 & 40,84 & 42,54 & 39,10 & 40,99 & 39,77 & 39,27 \\
\hline 25 & Comunicaçöes & 24,39 & 17,18 & 19,06 & 17,28 & 15,68 & 13,84 & 11,64 & 10,41 & 5,90 & 5,91 \\
\hline 26 & Instituiçöes financeiras & 13,40 & 12,61 & 13,30 & 13,96 & 12,54 & 11,44 & 9,96 & 9,47 & 8,50 & 8,61 \\
\hline 27 & Servicos prestados às familias & 83,95 & 88,10 & 86,23 & 84,37 & 84,82 & 96,38 & 99,00 & 98,90 & 98,43 & 100,31 \\
\hline 28 & Serviços prestados às empresas & 52,60 & 55,72 & 55,06 & 51,91 & 51,02 & 51,75 & 53,96 & 53,68 & 49,36 & 49,12 \\
\hline 29 & Aluguel de imóveis & 2,89 & 2,60 & 2,23 & 2,02 & 2,15 & 2,44 & 2,35 & 2,22 & 2,01 & 2,17 \\
\hline 30 & Administraçăo pública & 35,22 & 34,65 & 35,25 & 31,21 & 30,25 & 27,65 & 29,26 & 28,16 & 27,48 & 28,22 \\
\hline 31 & Serviços privados não-mercantis & 408,19 & 449,36 & 450,46 & 449,64 & 453,20 & 464,54 & 478,91 & 479,37 & 468,44 & 482,92 \\
\hline
\end{tabular}




\begin{tabular}{|c|c|c|c|c|c|c|c|c|c|c|c|}
\hline & 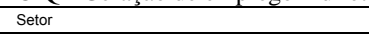 & 1990 & 1991 & 1992 & 1993 & 1994 & 1995 & 1996 & 1997 & 1998 & 1999 \\
\hline 1 & Agropecuária & 51,24 & 52,29 & 52,35 & 51,14 & 48,62 & 39,66 & 37,24 & 35,45 & 30,88 & 34,01 \\
\hline 2 & Extrativa mineral (exceto combustiveis) & 31,82 & 27,82 & 26,69 & 27,09 & 27,08 & 24,24 & 24,41 & 22,43 & 21,96 & 18,17 \\
\hline 3 & Ext.de petróleo e gás natural, carvão e outros comb. & 18,95 & 19,87 & 20,86 & 20,11 & 20,43 & 18,26 & 15,92 & 15,38 & 21,13 & 10,75 \\
\hline 4 & Fabricaçăo de minerais não-metálilios & 35,34 & 32,64 & 31,99 & 28,77 & 27,46 & 24,15 & 23,95 & 20,78 & 19,48 & 19,74 \\
\hline 5 & Siderurgia, met ñ-ferrosos e out.prod.metalurgicos & 43,58 & 38,91 & 38,25 & 34,17 & 33,91 & 28,60 & 27,86 & 26,12 & 25,88 & 24,88 \\
\hline 6 & Fabricaçăo e manutenção de máquinas e tratores & 30,36 & 28,03 & 24,88 & 19,56 & 20,67 & 16,40 & 16,05 & 14,92 & 14,63 & 13,63 \\
\hline 7 & Fab.de ap.e equip.de mat.elétrico eletrônico & 35,46 & 33,79 & 32,08 & 29,09 & 28,53 & 20,73 & 20,27 & 21,12 & 19,91 & 19,98 \\
\hline 8 & Fab.auto.cam.onib.outvveic, peças e acessórios & 40,21 & 37,44 & 35,42 & 30,56 & 29,76 & 23,27 & 22,42 & 22,74 & 21,76 & 21,04 \\
\hline 9 & Serrarias e fab. de artigos de madeira e mobiliário & 67,17 & 62,47 & 63,66 & 60,13 & 65,33 & 57,23 & 53,82 & 48,55 & 43,48 & 42,18 \\
\hline 10 & Indústria de papel e gráicca & 47,02 & 43,20 & 44,97 & 44,13 & 45,25 & 34,70 & 33,76 & 31,41 & 30,25 & 27,77 \\
\hline 11 & Indústria da borracha & 38,51 & 37,67 & 35,34 & 31,88 & 35,36 & 27,08 & 25,69 & 25,32 & 24,33 & 23,90 \\
\hline 12 & Fab. Elem. quimicos năo-petroq.e quim.diversos & 50,11 & 51,56 & 50,15 & 42,51 & 47,72 & 36,44 & 34,88 & 34,33 & 31,80 & 26,18 \\
\hline 13 & Refino de petróleo e indústria petroquímica & 23,39 & 24,89 & 21,00 & 13,82 & 15,85 & 11,66 & 12,03 & 12,30 & 11,73 & 10,99 \\
\hline 14 & Fab. de produtos farmacêuticos e de perfumaria & 41,01 & 45,82 & 38,19 & 32,79 & 35,11 & 26,33 & 24,87 & 24,30 & 22,30 & 23,01 \\
\hline 15 & Indústria de transformaçāo de material plástico & 22,31 & 23,38 & 22,00 & 16,83 & 18,17 & 13,82 & 13,58 & 13,47 & 13,07 & 13,88 \\
\hline 16 & Indústria têxill & 50,76 & 55,34 & 50,73 & 43,64 & 50,23 & 37,21 & 33,13 & 33,05 & 32,41 & 35,83 \\
\hline 17 & Fabricaçāo de artigos do vestuário e acessórios & 43,51 & 45,94 & 42,49 & 39,08 & 40,92 & 32,02 & 29,00 & 26,46 & 24,62 & 26,75 \\
\hline 18 & Fab. de calçados e de artigos de couro e peles & 61,15 & 59,37 & 50,80 & 48,15 & 52,14 & 40,82 & 37,42 & 34,41 & 32,72 & 30,39 \\
\hline 19 & Indústria de alimentos em geral & 118,41 & 118,24 & 109,85 & 110,03 & 116,55 & 97,79 & 87,96 & 82,05 & 70,66 & 73,76 \\
\hline 20 & Indústrias diversas & 31,48 & 31,01 & 30,84 & 28,21 & 27,54 & 26,76 & 25,17 & 23,19 & 22,90 & 23,20 \\
\hline 21 & Servicos industriais de utilidade pública & 22,22 & 26,39 & 24,02 & 16,64 & 14,87 & 8,99 & 8,28 & 8,82 & 8,26 & 7,98 \\
\hline 22 & Construçăo civil & 33,89 & 31,74 & 29,00 & 25,81 & 24,15 & 17,52 & 15,89 & 15,95 & 15,13 & 15,68 \\
\hline 23 & Comércio & 19,07 & 19,53 & 20,22 & 18,85 & 17,60 & 13,86 & 15,49 & 15,32 & 14,61 & 14,28 \\
\hline 24 & Transporte & 27,46 & 25,77 & 25,15 & 22,80 & 23,08 & 15,99 & 17,75 & 18,26 & 17,60 & 18,72 \\
\hline 25 & Comunicaçöes & 13,40 & 19,47 & 13,19 & 13,48 & 13,37 & 7,53 & 8,17 & 8,93 & 8,59 & 7,54 \\
\hline 26 & Instituiçöes financeiras & 8,03 & 10,10 & 6,33 & 5,32 & 9,36 & 12,73 & 14,34 & 14,84 & 14,51 & 15,17 \\
\hline 27 & Servicos prestados às familias & 41,18 & 40,15 & 37,53 & 36,28 & 39,30 & 26,61 & 23,21 & 22,45 & 21,23 & 23,90 \\
\hline 28 & Serviços prestados às empresas & 17,53 & 15,12 & 15,36 & 15,37 & 17,05 & 13,05 & 12,37 & 11,85 & 11,04 & 12,18 \\
\hline 29 & Aluguel de imóveis & 5,53 & 2,47 & 3,08 & 4,27 & 4,16 & 2,30 & 1,65 & 1,49 & 1,53 & 1,65 \\
\hline 30 & Administraçăo püblica & 21,58 & 24,30 & 24,43 & 25,95 & 24,54 & 21,78 & 18,29 & 18,53 & 17,40 & 17,22 \\
\hline 31 & Servicos privados năo-mercantis & 7,80 & 7,56 & 7,02 & 7.44 & 7,95 & 5,01 & 4,44 & 4,20 & 3,54 & 3,75 \\
\hline
\end{tabular}




\begin{tabular}{|c|c|c|c|c|c|c|c|c|c|c|c|}
\hline & Setor & 1990 & 1991 & 1992 & 1993 & 1994 & 1995 & 1996 & 1997 & 1998 & 1999 \\
\hline 1 & Agropecuária & 65,35 & 82,19 & 69,12 & 57,95 & 73,45 & 68,24 & 71,98 & 69,45 & 59,46 & 61,93 \\
\hline 2 & Extrativa mineral (exceto combustiveis) & 107,68 & 108,60 & 87,69 & 79,54 & 102,36 & 76,60 & 80,28 & 72,86 & 63,75 & 60,47 \\
\hline 3 & Ext.de petróleo e gás natural, carvão e outros comb. & 61.20 & 83,23 & 71,07 & 60,66 & 88.48 & 72.44 & 73.48 & 68.35 & 62.47 & 60,33 \\
\hline 4 & Fabricaçăo de minerais não-metâlicos & 91,52 & 99,00 & 83,71 & 69,41 & 88,90 & 71,51 & 76,28 & 67,40 & 58,44 & 59,14 \\
\hline 5 & Siderurgia, met ñ-ferrosos e out.prod.metalurgicos & 103,58 & 111,90 & 90,35 & 76,07 & 95,93 & 69,65 & 73,93 & 66,95 & 59,04 & 55,41 \\
\hline 6 & Fabricąăo e manutençăo de máquinas e tratores & 102,90 & 115,41 & 92,11 & 70,49 & 97,06 & 73,19 & 77,86 & 71,23 & 62,98 & 62,43 \\
\hline 7 & Fab.de ap.e equip.de mat.elétrico eletrônico & 93,79 & 105,28 & 85,13 & 71,02 & 93,09 & 61,44 & 64,05 & 62,12 & 55,12 & 52,54 \\
\hline 8 & Fab.auto.cam.onib.ut.veic., peças e acessórios & 106,38 & 126,26 & 102,75 & 77,26 & 98,13 & 65,91 & 68,23 & 62,14 & 54,75 & 52,05 \\
\hline 9 & Serrarias e fab. de artigos de madeira e mobiliário & 107,14 & 114,20 & 98,20 & 83,06 & 102,29 & 80,31 & 83,29 & 76,32 & 68,84 & 67,46 \\
\hline 10 & Indústria de papel e gráfica & 121,46 & 118,55 & 106,21 & 98,15 & 120,13 & 78,20 & 81,31 & 74,40 & 66,64 & 62,67 \\
\hline 11 & Indústria da borracha & 80,20 & 96,83 & 77,44 & 59,41 & 83,04 & 60,49 & 63,96 & 59,09 & 51,94 & 49,35 \\
\hline 12 & Fab. Elem. quimicos năo-petroq.e quim.diversos & 85,97 & 97,94 & 81,01 & 61,38 & 83,53 & 64,15 & 66,69 & 63,81 & 55,63 & 53,93 \\
\hline 13 & Refino de petróleo e indústria petroquímica & 63,77 & 86,03 & 64,36 & 43,70 & 71,49 & 53,78 & 57,08 & 54,99 & 49,03 & 48,50 \\
\hline 14 & Fab. de produtos farmacêuticos e de perfumaria & 88,46 & 106,99 & 83,77 & 67,62 & 91,98 & 67,29 & 69,79 & 68,26 & 59,71 & 58,01 \\
\hline 15 & Indústria de transformação de material plastico & 82,73 & 98,90 & 82,55 & 64,17 & 89,72 & 65,52 & 69,67 & 65,35 & 57,90 & 57,82 \\
\hline 16 & Industria têxtil & 77,15 & 98,64 & 83,00 & 66,49 & 90,45 & 62,15 & 63,04 & 59,61 & 52,84 & 51,35 \\
\hline 17 & Fabricaăăo de artigos do vestuário e acessórios & 117,74 & 137,37 & 116,29 & 105,47 & 129,33 & 84,55 & 84,17 & 77,31 & 69,38 & 68,92 \\
\hline 18 & Fab. de calcados e de artigos de couro e peles & 116,89 & 121,74 & 96,02 & 81,08 & 110,08 & 75,21 & 78,17 & 72,34 & 64,44 & 62,12 \\
\hline 19 & Industria de alimentos em geral & 82,65 & 95,23 & 79,86 & 66,01 & 84,05 & 69,82 & 73,00 & 67,66 & 58,91 & 59,10 \\
\hline 20 & Industrtras diversas & 97,17 & 109,41 & 93,48 & 76,63 & 99,02 & 79,90 & 79,64 & 73,11 & 64,15 & 61,30 \\
\hline 21 & Serviços industriais de uttilidade pubblica & 118,48 & 123,91 & 109,67 & 111,66 & 130,43 & 81,53 & 80,78 & 80,89 & 66,65 & 65,40 \\
\hline 22 & Construçăo civil & 94,56 & 104,96 & 84,44 & 67,58 & 84,41 & 64,28 & 67,35 & 66,01 & 57,79 & 59,07 \\
\hline 23 & Comércio & 125,99 & 139,16 & 123,23 & 105,80 & 129,09 & 90,94 & 93,29 & 88,89 & 80,17 & 77,67 \\
\hline 24 & Transporte & 128,86 & 140,36 & 116,58 & 101,18 & 123,84 & 79,74 & 85,34 & 84,22 & 75,64 & 70,24 \\
\hline 25 & Comunicaçöes & $\begin{array}{l}115,69 \\
1150\end{array}$ & 123,97 & 101,22 & 82,80 & 113,08 & 79,06 & $\begin{array}{l}0,0,23 \\
79,23\end{array}$ & 75,20 & 67,37 & 68,43 \\
\hline 26 & Instituiçöes financeiras & 88,68 & 118,02 & 85,40 & 69,51 & 113,48 & 96,73 & 100,31 & 95,75 & 82,78 & 83,75 \\
\hline 27 & Servicos prestados às familias & 144,17 & 146,41 & 127,67 & 110,08 & 134,51 & 89,50 & 90,06 & 87,84 & 80,61 & 81,82 \\
\hline 28 & Serviços prestados às empresas & 135,90 & 128,82 & 121,07 & 101,05 & 136,42 & 96,12 & 94,19 & 91,16 & 82,84 & 82,22 \\
\hline 29 & Aluguel de imóveis & 30,89 & 47,37 & 35,50 & 26,07 & 50,05 & 58,80 & 64,10 & 62,51 & 52,93 & 58,23 \\
\hline 30 & Administraçăo pública & 194,04 & 185,51 & 168,89 & 154,58 & $\begin{array}{r}30,00 \\
185,64\end{array}$ & $\begin{array}{l}316,50 \\
11,55\end{array}$ & 115,71 & 110,36 & 99,19 & $\begin{aligned} 0,20 \\
100,79\end{aligned}$ \\
\hline 31 & Serviços privados não-mercantis & 205,00 & 200,69 & 182,73 & 174,74 & 198,78 & 130,71 & 126,68 & 120,23 & 110,14 & 112,35 \\
\hline
\end{tabular}




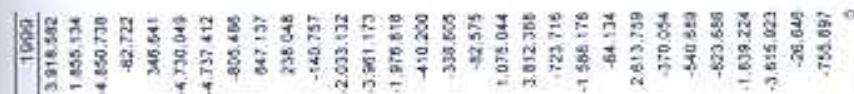

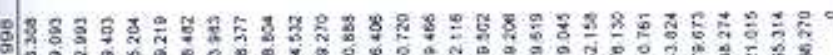

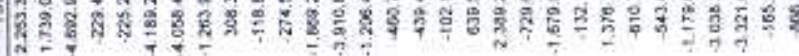

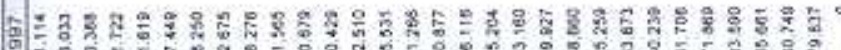

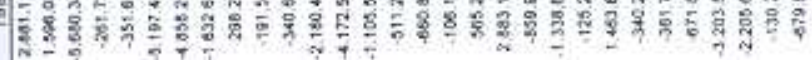

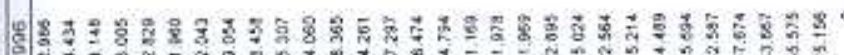

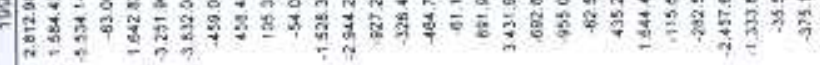

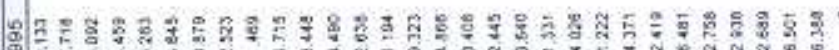

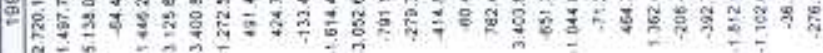

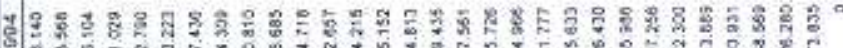

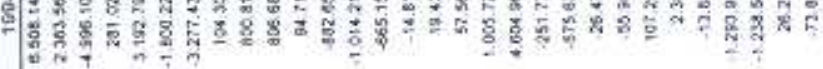

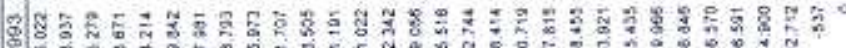

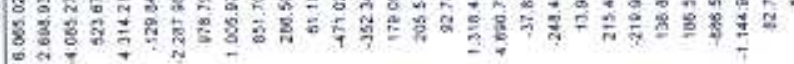

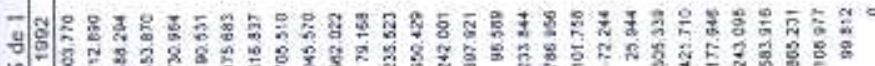

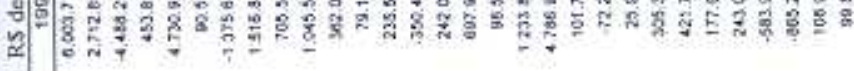
ㄱ.

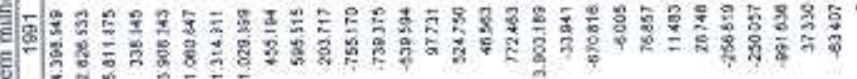

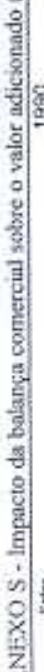

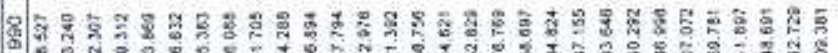

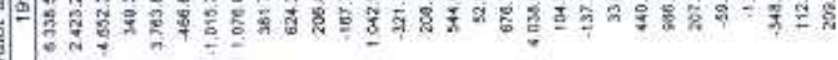

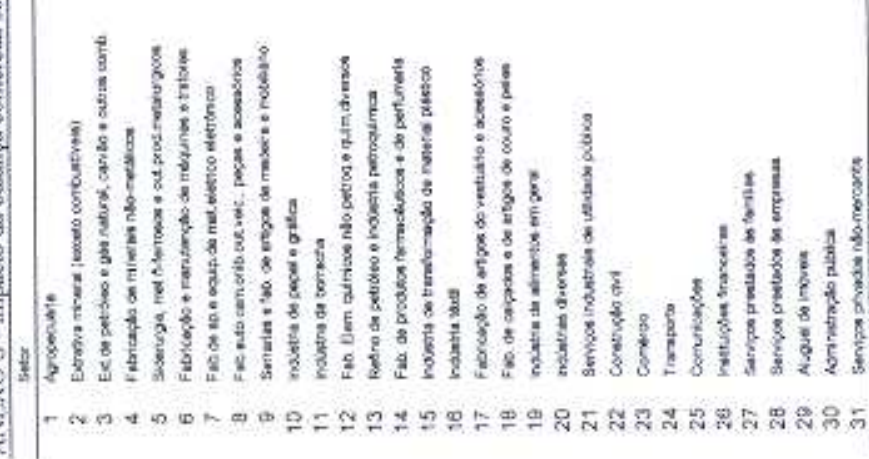




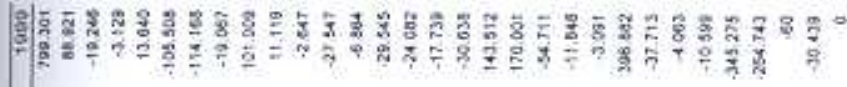

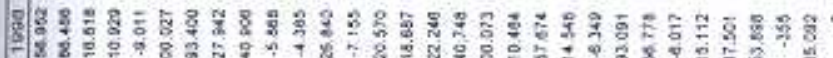

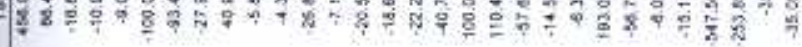

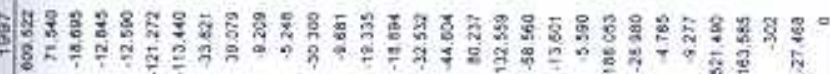

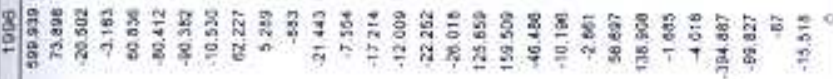

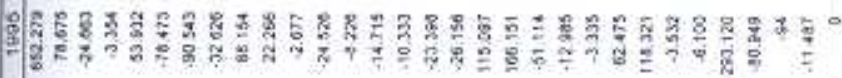

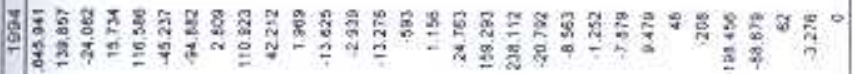

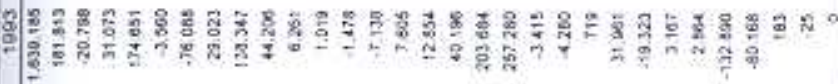

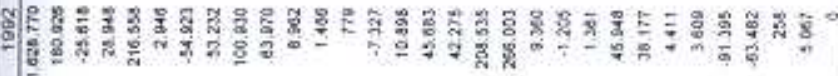

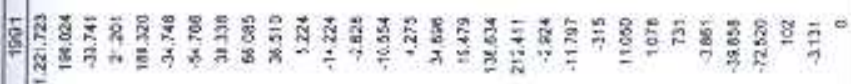

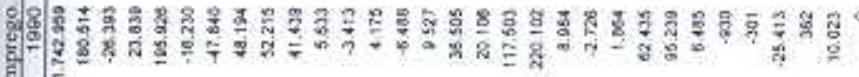




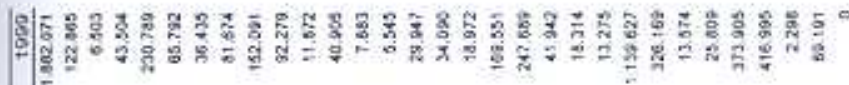

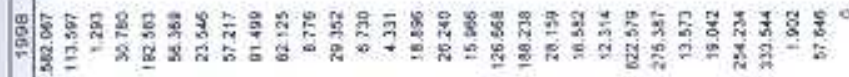
列

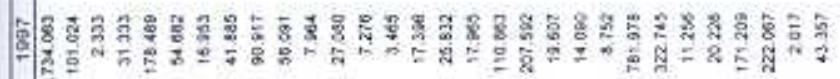

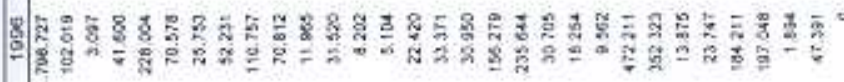

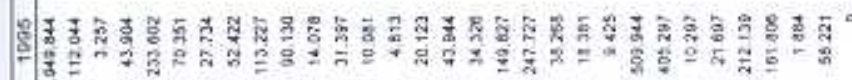

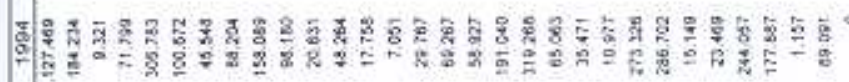

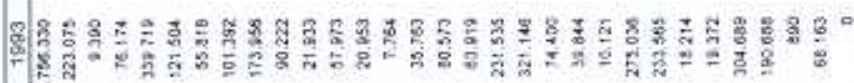

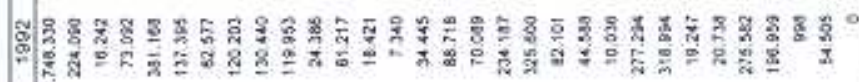

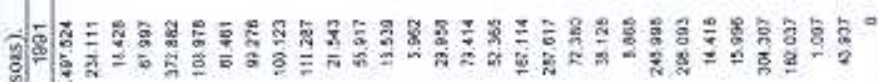
ह)

간.

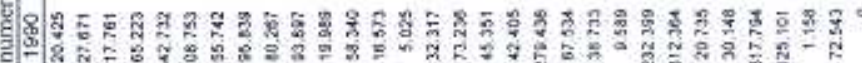

.

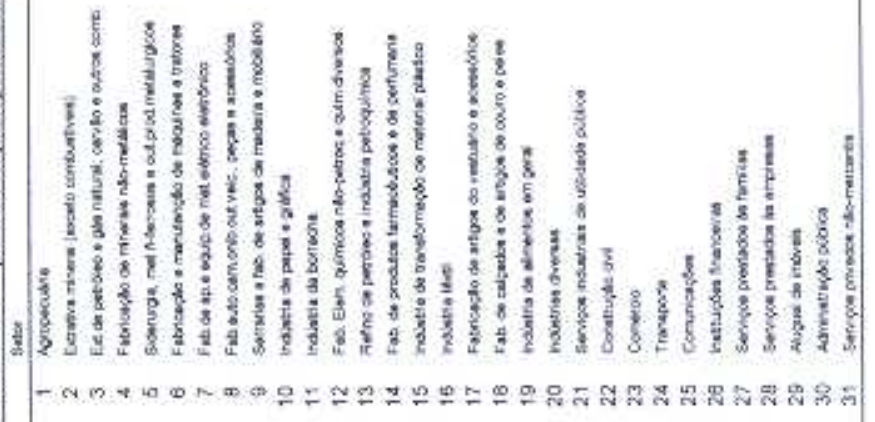




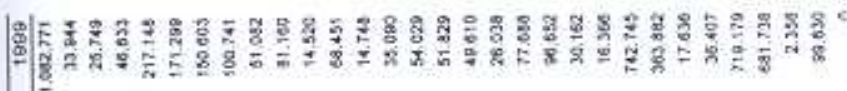

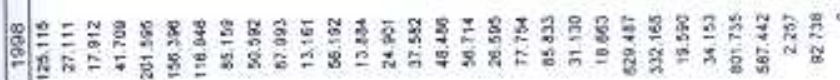

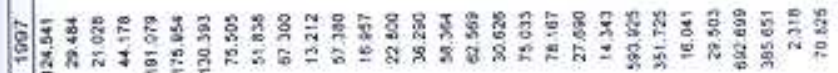
政

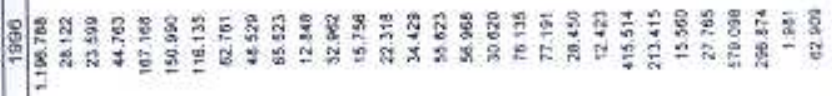

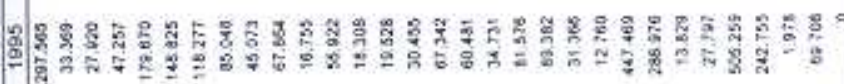

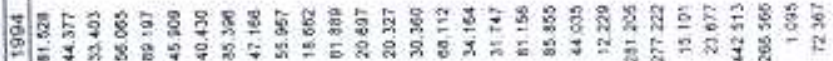

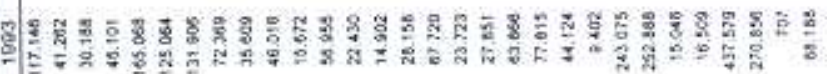

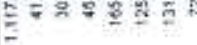

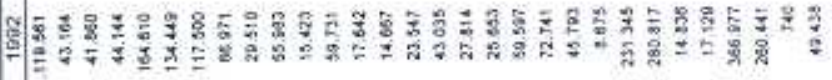

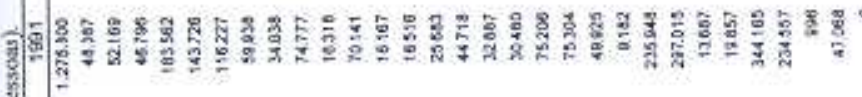
ㄱ.

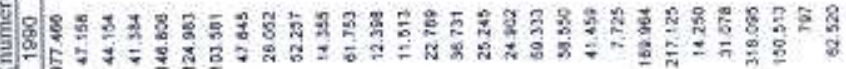
해를

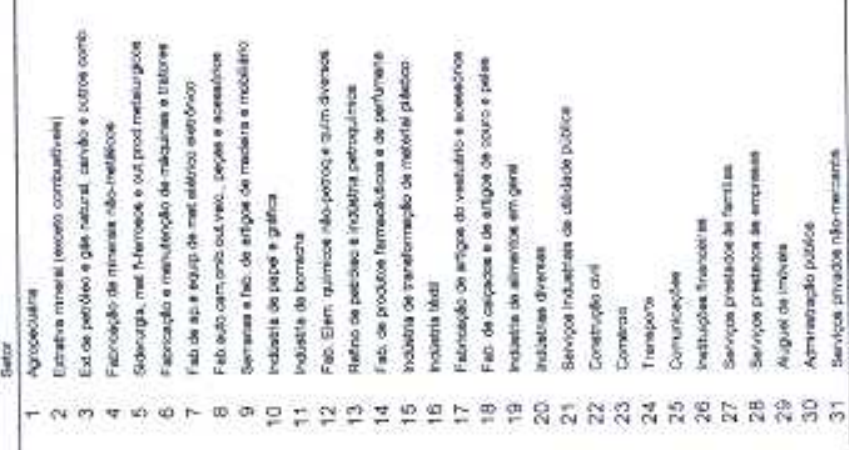




\title{
4 A ESTRUTURA SETORIAL DA OFERTA DE POSTOS DE TRABALHO NO BRASIL NA DÉCADA DE 1990
}

\section{Resumo}

Este artigo analisa a estrutura da oferta de postos de trabalho no Brasil na década de 1990 a partir da compatibilização dos dados da Pesquisa Nacional por Amostra de Domicílios (PNAD) e das Contas Nacionais, publicados pelo Instituto Brasileiro de Geografia e Estatística (IBGE). Por meio de uma análise de insumo-produto, o trabalho mostra a evolução da importância dos componentes da demanda total na oferta setorial de postos de trabalho e as características gerais da mão-de-obra ocupada na economia brasileira na década de 1990 .

Palavras-chave: Mercado de trabalho, Insumo-produto, Perfil da mão-de-obra.

\begin{abstract}
This article analyzes the structure of the work positions supply in Brazil in the decade of 1990 starting from the compatibilization of the National Sample of Domiciles Research (PNAD) and National Accounts data, published by the Brazilian Institute of Geography and Statistics (IBGE). Through an input-output analysis, the work shows the evolution of the importance of the total demand components in the sectorial offer of work positions and the main characteristics of the occupied workers in the Brazilian economy in the last nineties.
\end{abstract}

Key Words: Labor market, Input-output, Workers characteristics. 


\section{Introdução}

Este artigo analisa a estrutura do mercado de trabalho no Brasil na década de 1990 a partir da compatibilização da Pesquisa Nacional por Amostra de Domicílios (PNAD) e dos dados das Contas Nacionais, publicados pelo Instituto Brasileiro de Geografia e Estatística (IBGE).

Por meio de uma análise de insumo-produto, o trabalho mostra a evolução da importância dos componentes da demanda total na oferta setorial de postos de trabalho e as características gerais do emprego para a economia brasileira na década de 1990.

Além desta introdução, o artigo tem cinco seções. Inicialmente são feitas considerações sobre o mercado de trabalho brasileiro nos anos de 1990 e, em seguida, são apresentadas aplicações do modelo de insumo-produto que analisam aspectos de seu funcionamento. A quarta seção apresenta a metodologia e os dados a serem utilizados no trabalho. A quinta seção descreve os resultados, mostrando as características da mãode-obra ocupada no Brasil, a participação dos componentes da demanda total na oferta de postos de trabalho e as características da mão-de-obra ocupada em cada um dos setores. Por último, a sexta seção apresenta as considerações finais.

\section{Mercado de trabalho brasileiro nos anos de 1990}

De acordo com MTb (1998), a geração de empregos no país deslocou-se do setor industrial, nos anos 1970, para o setor serviços, nos anos 1980 e 1990. Neste período, particularmente na década de 1990, o setor industrial esteve sob forte pressão competitiva, em consequiência das práticas de ajuste e do processo de terceirização de serviços.

Mattoso \& Baltar (1996) e Lacerda (2000) afirmam que houve uma desintegração das cadeias produtivas na década de 1990, as quais diminuíram sua capacidade de gerar emprego e valor agregado. A diminuição do ritmo de atividades, em conjunto com a desintegração da estrutura de produção, fizeram com que o setor 
industrial perdesse não só a capacidade de gerar empregos mas também o poder de alavancar o crescimento da economia nacional.

Cardoso (2001) mostrou que, para o mesmo período, houve um aumento das atividades dos setores intensivos em mão-de-obra com pouca qualificação, particularmente no setor terciário, devido à competição dos trabalhadores para obter uma ocupação.

No que se refere à situação ocupacional, o processo de terceirização de serviços por parte das indústrias conduziu à transferência de parte de seus postos de trabalho formais para o setor de serviços, tanto formal quanto informal. Neste último predominam as pequenas e médias empresas, trabalhadores assalariados sem Carteira de Trabalho e trabalhadores estabelecidos por conta própria.

Em 1991, a parcela dos empregados com Carteira de Trabalho no total da mão-de-obra ocupada era de 53,8\%. Em 1997 era igual a 46,9\%. Paralelamente, a parcela do emprego sem Carteira de Trabalho e dos autônomos cresceu, respectivamente, de $20,8 \%$ para $24,6 \%$ e de quase $20,0 \%$ para $23,3 \%$ no mesmo período (MTb, 1998)

No quesito anos de estudo, Rosandiski \& Silva (1999) mostraram que houve um aumento do nível de escolaridade da mão-de-obra ocupada na década. Porém, o tempo de serviço indica que também ocorreu uma enorme instabilidade no emprego. Deste modo, os autores concluem que o aumento da escolaridade é resultado de uma conduta mais seletiva das empresas na contratação de mão-de-obra escolarizada e não de uma demanda por novas qualificações impostas pelo processo de modernização da estrutura produtiva.

As estimativas de escolaridade da população economicamente ativa no Brasil, isto é, pessoas com 10 anos ou mais, indicam que houve um aumento de menos de 4 anos de estudo para 6,4 anos neste período. Para os homens, a escolaridade média passou para 6 anos e entre as mulheres para 7 anos. A escolaridade entre os jovens é maior, mas não ultrapassa 8 anos (MTb, 1998). Deste modo, nota-se que a escolaridade 
média da mão-de-obra ocupada no Brasil no período em análise é baixa se comparada à média de 8 anos de estudo na América Latina.

Quanto a idade do trabalhador, Amadeo (1998) mostra uma redução do emprego dos jovens entre 15 e 24 anos e dos adultos com mais de 65 anos. Segundo o autor, desde 1994 observa-se um movimento de queda da oferta de trabalho entre os membros mais jovens das famílias (15 a 24 anos). São as pessoas com idade intermediária, entre 25 e 39 anos que têm aumentado sua participação no mercado de trabalho. Se, de um lado, os mais jovens estão postergando sua entrada no mercado de trabalho, de outro, tem crescido a exigência das empresas por trabalhadores mais experientes e mais qualificados.

Em relação à participação feminina no mercado de trabalho, Ferranti (2002) argumenta que ela aumentou de menos de 4 em cada 10 mulheres em 1976 para quase 6 de cada 10 ocupadas em 2001. Além disso, a participação masculina diminuiu de 61 para cada 100 homens em 1991 para 56 em cada 100 homens em $2001^{1}$.

Foguel (1998) analisa um conjunto de evidências sobre a utilização da jornada de trabalho em tempo parcial no Brasil para o período 1992 a 1996 mostrando que, embora a jornada de trabalho em tempo parcial venha crescendo desde 1992, a proporção de empregados que trabalhavam menos que 25 horas semanais representa apenas $8 \%$ do total de empregados nas áreas urbanas do país. Ademais, existe uma diferença entre a proporção de empregados homens e mulheres com jornada de trabalho menor que 25 horas semanais. Entre os homens esta taxa é de $4 \%$ e entre as mulheres essa proporção é aproximadamente 3,5 vezes maior.

$\mathrm{O}$ autor argumenta ainda, que se comparado o grupo de empregados como um todo no Brasil com a mesma categoria nos países da OECD (Organização para cooperação econômica e desenvolvimento), o Brasil situa-se um pouco abaixo da média destes países (14\%), com participação equivalente a 13,2\%. No entanto, considerandose os trabalhadores com carteira assinada, a posição brasileira passa a ser

${ }^{1} \mathrm{O}$ autor considerou os homens e mulheres na idade de 15 a 65 anos que trabalhavam ou procuravam emprego. 
significativamente mais baixa $(7,6 \%)$ do que a média da OECD (14\%). Segundo o autor, o Brasil assume a vigésima terceira posição entre os 29 países que menos utilizam a jornada de trabalho em tempo parcial, sendo que seu uso é cerca de $45 \%$ menor que nos países da OECD.

\section{Insumo-produto aplicado ao mercado de trabalho}

Uma forma alternativa e mais precisa para a avaliação da oferta de postos de trabalho a da relação destes com a produção intersetorial e com a demanda final é a técnica de insumo-produto.

Chinkook \& Schluter (1998) examinaram os efeitos do comércio, demanda doméstica, tecnologia e produtividade do trabalho na demanda por trabalhador qualificado e não-qualificado nos Estados Unidos no período de 1972 a 1992, utilizando as tabelas de insumo-produto para os anos de 1972, 1977, 1982, 1987 e 1992. Os autores concluíram que as mudanças no comércio não têm sido o principal fator indutor de mudanças na demanda por trabalhadores qualificados em relação aos não qualificados. Segundo eles, quaisquer efeitos negativos da balança comercial relacionados ao emprego de mão-de-obra não qualificada foram compensados pela demanda de trabalho não qualificado para uso doméstico, o que sugere um pequeno papel das importações na perda de trabalho não qualificado na economia. Deste modo, o comércio desempenhou um pequeno, senão insignificante, papel na demanda de trabalhadores qualificados versus não qualificados.

Cuadrado-Roura (1999) analisou o mercado de trabalho no setor serviços para o caso espanhol entre 1980 e 1997. Dentre as várias conclusões, observou um intenso processo de terciarização do emprego, na medida em que o setor serviços apresentou nos últimos vinte anos um aumento de 20 pontos percentuais na distribuição setorial do emprego. Para o autor, o lento crescimento da produtividade dos serviços é uma das causas do crescimento do emprego no setor terciário, embora exista uma mudança importante quanto às exigências de qualificação, aumentando o nível de estudo exigido. 
Também utilizando um modelo de insumo-produto, Rocha (1997) analisou a composição do crescimento do setor Serviços na economia brasileira no período de 1985 a 1992, mostrando que o aumento da sua participação na demanda total foi justificado pelo crescimento da demanda final, principalmente dos segmentos relacionados com o setor público. O autor também conclui que o setor Serviços apresenta aparentemente pouca influência sobre a produtividade dos demais setores da economia, na medida em que sua função como produtor de insumos é bastante reduzida.

Melo et al (1998) analisaram o setor Serviços sob a ótica da renda e do emprego no período de 1985 a 1995, mostrando que seu crescimento não contribuiu para a expansão dos demais setores, logo este setor não poderia ser considerado chave. Os autores concluem ainda que, na última década, a absorção de mão-de-obra neste setor seguiu duas dinâmicas distintas, crescendo significativamente entre 1985 e 1990 e mantendo-se estável entre 1990 e 1995. Segundo o autor, nos vinte anos analisados, houve uma mudança radical na posição ocupacional, aumentando a proporção de trabalhadores por conta própria e sem carteira, expandindo, deste modo, as relações informais na economia.

Carvalheiro (2000) avaliou os efeitos das reformas econômicas da primeira metade da década de 1990, verificando um aumento da produtividade média do trabalho para a maioria dos setores.

Embora todos estes trabalhos propiciem uma visão abrangente do mercado de trabalho brasileiro na década de 1990, não tocam em pontos importantes, os quais são aqui analisados. A partir da compatibilização dos dados das PNADs e das matrizes de insumo-produto, obtidas das Contas Nacionais, é possível mostrar as mudanças setoriais na oferta de postos de trabalho e, conseqüentemente do perfil exigido de cada trabalhador, ao longo da década de 1990. O modelo de insumo-produto possibilita ainda identificar a importância dos componentes da demanda total na geração de postos de trabalho nos vários setores da economia. 


\section{Material e Métodos}

Esta seção informa a fonte dos dados utilizados no trabalho, bem como a metodologia empregada para verificar as características setoriais do mercado de trabalho brasileiro.

\subsection{Dados da pesquisa}

A decomposição da demanda total foi feita a partir das matrizes de insumo-produto publicadas pelo Instituto Brasileiro de Geografia e Estatística (IBGE) para os anos de 1990 a 1996. Para o restante da década, foram construídas matrizes de acordo com o método proposto em Guilhoto et al (2002), o qual utiliza os dados disponíveis das Contas Nacionais.

As características da mão-de-obra ocupada foram obtidas a partir dos dados da Pesquisa Nacional por Amostra de Domicílios (PNAD) para os anos de 1990, $1992,1993,1995$ a $1999^{2}$.

A análise do perfil do trabalhador levou em conta o gênero e a idade da mão-de-obra ocupada, a situação na ocupação, a jornada de trabalho, o tempo de serviço, a idade de ingresso no primeiro trabalho e os anos de estudo, considerados como proxy da qualificação do trabalhador (Quadro 1).

\footnotetext{
2 Por ser ano de realização do Censo, a PNAD não foi realizada em 1991. Em 1994, dificuldades internas do IBGE impossibilitaram a realização da pesquisa.
} 


\begin{tabular}{|c|c|}
\hline 1. Idade & $\begin{array}{l}\text { O levantamento foi feito por meio da pesquisa do dia, mês e ano de } \\
\text { nascimento da pessoa ou da idade presumida da pessoa que não soubesse a } \\
\text { data de nascimento. }\end{array}$ \\
\hline 2. Situação na ocupação & $\begin{array}{l}\text { - Empregado: Pessoa que trabalhava para um empregador, geralmente } \\
\text { obrigando-se ao cumprimento de uma jornada de trabalho e recebendo } \\
\text { uma remuneração em dinheiro, mercadorias, produtos ou benefícios. } \\
\text { Incluindo-se a pessoa que prestava o serviço militar obrigatório, } \\
\text { sacerdote, ministro de igreja, pastor, rabino, frade, freira e outros } \\
\text { cléricos; incluindo o trabalhador doméstico nesta categoria ( pessoa que } \\
\text { trabalhava serviço doméstico remunerado em dinheiro ou benefícios, em } \\
\text { uma ou mais unidades domiciliares); } \\
\text { - Conta-própria: pessoa que trabalhava explorando o seu próprio } \\
\text { empreendimento, sozinha ou com sócio, sem ter empregado e contando, } \\
\text { ou não, com a ajuda de trabalhador não remunerado; } \\
\text { - Empregador: pessoa que trabalhava explorando o seu próprio } \\
\text { empreendimento, com pelo menos um empregado; } \\
\text { - Trabalhador não remunerado membro da unidade domiciliar: pessoa que } \\
\text { trabalhava sem remuneração, durante pelo menos uma hora na semana } \\
\text { ou durante pelo menos uma hora na semana, como estagiário, aprendiz } \\
\text { ou em ajuda a instituição religiosa, beneficiente ou de cooperativismo; }\end{array}$ \\
\hline $\begin{array}{l}\text { 3. Jornada de trabalho } \\
\text { (horas habitualmente } \\
\text { trabalhadas por } \\
\text { semana) }\end{array}$ & $\begin{array}{l}\text { Número de horas habitualmente trabalhadas por semana no trabalho } \\
\text { principal, no secundário e nos demais trabalhos que a pessoa tinha na } \\
\text { semana de referência; }\end{array}$ \\
\hline 4. Tempo de serviço & Número de anos permanecidos até a semana de referência \\
\hline $\begin{array}{l}\text { 5. Idade de ingresso no } \\
\text { primeiro trabalho }\end{array}$ & $\begin{array}{l}\text { Para as pessoas ocupadas no período de } 365 \text { dias foi pesquisada a idade que } \\
\text { tinham quando começaram no primeiro trabalho; }\end{array}$ \\
\hline 6. Anos de estudo & $\begin{array}{l}\text { Obtida em função da série e do grau que a pessoa estava freqüientando ou } \\
\text { havia freqüentado, considerando a última série concluída com aprovação. }\end{array}$ \\
\hline
\end{tabular}

Quadro1 - Definição das variáveis da PNAD que caracterizam o perfil da mão-de-obra ocupada.

\subsection{Compatibilização dos dados}

Inicialmente, tendo em vista que o questionário da pesquisa de 1990 é diferente dos demais anos, foi necessário ajustá-lo.

Posteriormente, como os dados setoriais da PNAD são apresentados em 167 atividades distintas, procurou-se distribuí-las tomando-se por base os 42 setores originalmente apresentados nas matrizes de insumo-produto. Este processo possibilitou o agrupamento dos dados setoriais contidos na PNAD em 31 setores $^{3}$.

\footnotetext{
${ }^{3}$ Ver Anexo A.
} 
Foi necessário, então, compatibilizar as informações setoriais da PNAD com as matrizes de insumo-produto. Assim, os 42 setores das matrizes de insumoproduto foram também agrupados em 31 setores. No entanto, para uma melhor apresentação no texto, ao invés de apresentar todos, optou-se por agrupa-los em sete macro setores.

\subsection{Modelo de insumo-produto}

A informação fundamental da análise insumo-produto consiste nos fluxos de produto de cada setor industrial considerado como produtor para cada um dos setores considerados como consumidores. Esta informação é representada por intermédio de uma tabela de relações interindustriais na qual as linhas descrevem a distribuição da produção de um setor através de toda a economia e as colunas mostram a composição dos insumos requeridos por uma industria particular para desenvolver sua produção (Miller e Blair, 1985).

As relações do modelo de insumo-produto são representadas esquematicamente na figura 1. De acordo com ela pode-se observar que as vendas de um determinado setor são utilizadas como insumo no processo produtivo de outro setor ou podem também ser consumidas pelos vários componentes da demanda final. De outro lado, observando-se as colunas nota-se que o processo produtivo de um determinado setor exige uma determinada quantidade de insumos que podem ser originados da própria economia ou importados. Este mesmo processo produtivo é responsável tanto pelo pagamentos de impostos quanto pela geração de valor adicionado, na forma de geração de salários e de excedentes. 


\begin{tabular}{|c|c|c|c|c|c|c|c|c|c|c|c|}
\hline & \multicolumn{4}{|c|}{ SETORES COMPRADORES } & \multicolumn{5}{|c|}{ DEMANDA FINAL } & \multirow{2}{*}{\begin{tabular}{|c} 
PRODUÇ̃̃̃ \\
TOTAL
\end{tabular}} \\
\hline & & $A_{1}$ & $A_{2}$ & $A_{j}$ & $A_{n}$ & Investimento & Exportaçōes & $\begin{array}{c}\text { Variação } \\
\text { de } \\
\text { estoques }\end{array}$ & $\begin{array}{c}\text { Consumo } \\
\text { do } \\
\text { Governo }\end{array}$ & $\begin{array}{c}\text { Consumo } \\
\text { das } \\
\text { Famílias }\end{array}$ & \\
\hline \multirow{4}{*}{ 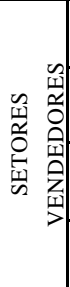 } & $A_{1}$ & & & & & & & & & & \\
\hline & $A_{2}$ & & & & & & & & & & \\
\hline & $A_{i}$ & & & & & & & & & & \\
\hline & $A_{n}$ & & & & & & & & & & \\
\hline & Importações & & & & & & & & & & \\
\hline \multirow{3}{*}{ 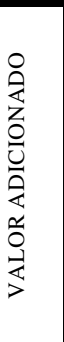 } & Remunerações & & & & & & & & & & \\
\hline & $\begin{array}{l}\text { Impostos } \\
\text { indiretos } \\
\text { líquidos }\end{array}$ & & & & & & & & & & \\
\hline & $\begin{array}{l}\text { Excedente } \\
\text { Operacional } \\
\text { Bruto }\end{array}$ & & & & & & & & & & \\
\hline \multicolumn{2}{|c|}{$\begin{array}{l}\text { PRODUÇÁO } \\
\text { TOTAL }\end{array}$} & & & & & & & & & & \\
\hline
\end{tabular}

Figura 1 - Tabela de insumo-produto.

A estrutura matemática de um sistema de insumo-produto consiste em um conjunto de $n$ equações lineares com $n$ incógnitas.

Inicialmente, deve-se considerar que a demanda de um dado setor $j$ por insumos originados de outros setores é relacionada com o montante de bens produzidos por este mesmo setor $j$. No entanto, a demanda final, isto é, a demanda das famílias, do governo ou de outros países (exportações), tende a ser maior por bens finais e não por insumos. A demanda desses agentes e, por conseqüência, a magnitude de suas compras de cada um dos setores industriais, é determinada por considerações relativamente não relacionadas com o montante produzido nestas unidades (Miller e Blair, 1985).

Deste modo, assumindo que a economia é dividida em $n$ setores,

$$
X_{i}=z_{i 1}+z_{i 2}+\cdots+z_{i n}+C_{i}+I_{i}+E_{i}
$$

onde: 
$X_{i} \quad$ é a produção total do setor $i$

$z_{i j} \quad$ é o valor monetário do fluxo do setor $i$ para o setor $j$

$C_{i} \quad$ é a produção do setor $i$ consumida domesticamente

$I_{i} \quad$ é a produção do setor $i$ destinada ao investimento

$E_{i} \quad$ é a produção do setor $i$ exportada

Dado que cada um dos $n$ setores terá uma equação semelhante, pode-se escrever

$$
\sum_{i=1}^{n} z_{i j}+C_{i}+I_{i}+E_{i} \equiv X_{i}
$$

\subsection{Produtividade Aparente}

A produtividade aparente foi calculada pela razão entre o valor adicionado a preços de 1999 e o número de pessoas ocupadas, ou seja:

$$
P A_{i}=\frac{V A_{i}}{P O_{i}}
$$

onde:

$P A_{i} \quad$ é a produtividade aparente do setor $i$;

$V A_{i} \quad$ é o valor adicionado do setor $i$; e

$P O_{i}$ é o número de pessoas ocupadas no setor $i$.

\subsection{Análise de participação (shift share)}

A análise shif share, tal como proposta em Cuadrado-Roura (1999) e Cuadrado-Roura et al. (2000) ${ }^{4}$, pode ser utilizada para a decomposição da demanda total

4 CUADRADO-ROURA, J.R.; IGLESIAS-FERNANDES, C.; LLORENTE-HERAS, R. Emplyment tertiarization and emerging new patterns of work: the spanish case. /Apresentado ao 47. North American Meetings of the RSAI, Chicago, 2000/ 
de cada setor da atividade econômica, permitindo obter o efeito destes componentes no emprego de cada um dos setores.

Segundo Cuadrado-Roura et al. (2000), o emprego total de um dado setor pode ser desagregado em um componente doméstico (consumo das famílias, consumo do governo, formação bruta de capital fixo e variação de estoques), um componente externo (exportações) e um componente intermediário (consumo intermediário), isto é,

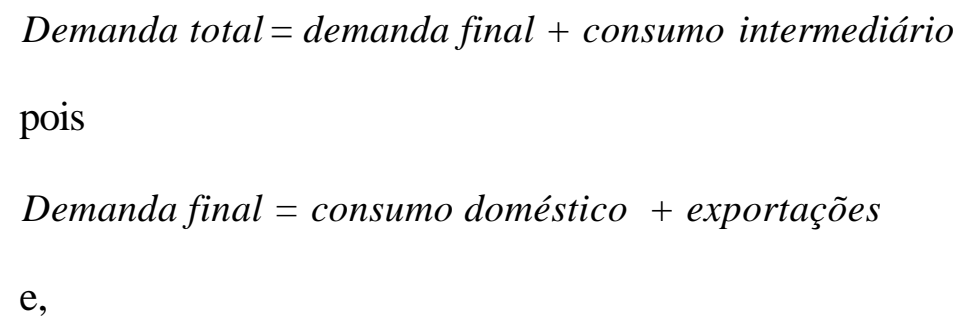

Partindo-se da hipótese que o emprego em cada um dos setores é distribuído na proporção correspondente ao produto do setor no consumo doméstico, consumo intermediário e exportação, obtém-se:

$$
E_{i}=E_{i}^{D C}+E_{i}^{C I N}+E_{i}^{X}
$$

onde $E_{i}$ é o emprego do setor $i ; E_{i}^{D C}$ é o emprego correspondente ao consumo doméstico; $E_{i}^{C I N}$ é o emprego do consumo intermediário; e, $E_{i}^{X}$ é o emprego da exportação.

\section{6 Índice de qualificação relativa}

O número de anos de estudo foi tomado como proxy para avaliar a qualificação da mão-de-obra ocupada nos 31 setores. Para tanto, foram utilizados três índices de qualificação relativa, a saber: 


$$
I B Q R_{i t}=\frac{\frac{\text { número de pessoas com baixa qualificaç ão no setor } i}{\text { total de pessoas empregadas no setor } i}}{\frac{\text { número de pessoas com baixa qualificaç ão nos } n \text { setores }}{\text { número de pessoas ocupadas nos } n \text { setores }}}
$$

onde

$I B Q R_{i t}$ é o índice de baixa qualificação relativa do setor $i$ no ano $t$, considerando-se como baixa qualificação os postos de trabalho ocupados por pessoas sem instrução até 7 anos de estudo.

$$
I M Q R_{i t}=\frac{\frac{\text { número de pessoas com média qualificaç ão no setor } i}{\text { total de pessoas empregas no setor } i}}{\frac{\text { número de pessoas com média qualificaç ão nos } n \text { setores }}{\text { número de pessoas ocupadas nos } n \text { setores }}}
$$

onde

$I M Q R_{i t}$ é o índice de média qualificação relativa do setor $i$ no ano $t$, considerando-se como média qualificação os postos de trabalho ocupados por pessoas que possuem de 8 a 14 anos de estudo.

$$
I A Q R_{i t}=\frac{\frac{\text { número de pessoas com alta qualificaç ão no setor } i}{\text { total de pessoas empregadas no setor } i}}{\frac{\text { número de pessoas com alta qualificaç ão nos } n \text { setores }}{\text { número de pessoas ocupadas nos } n \text { setores }}}
$$

onde

$I A Q R_{i t}$ é o índice de alta qualificação relativa do setor $i$ no ano $t$, considerando-se como alta qualificação os postos de trabalho ocupados por pessoas que possuem 15 ou mais anos de estudo.

Logo, quando qualquer um dos três índices for maior que a unidade, significa que o setor em questão, no ano analisado, emprega proporcionalmente mais pessoas que a economia para um dado nível de qualificação.

Naturalmente, quanto mais especializada for a atividade de um determinado setor, espera-se que tanto o índice de média qualificação relativa quanto o 
índice de alta qualificação relativa tenham valores próximos ou maiores que a unidade. Do mesmo modo, quanto menos especializada for a atividade de um dado setor, maior será o índice de baixa qualificação relativa.

\section{Resultados}

Esta seção mostra os resultados do trabalho e está dividida em quatro partes. A primeira delas apresenta a as características da mão-de-obra ocupada no Brasil nos anos 1990. A segunda mostra o panorama setorial da mão-de-obra ocupada no Brasil. A terceira parte trata do efeito de cada um dos componentes da demanda total ma oferta de postos de trabalho e a quarta parte mostra o perfil da mão-de-obra ocupada nos macro setores 5 .

\subsection{Características da mão-de-obra ocupada no Brasil}

A mão-de-obra ocupada no Brasil na década de 1990 é predominantemente masculina. Somente algo em torno de $1 / 3$ é ocupada pela mão-deobra feminina (figura 2).

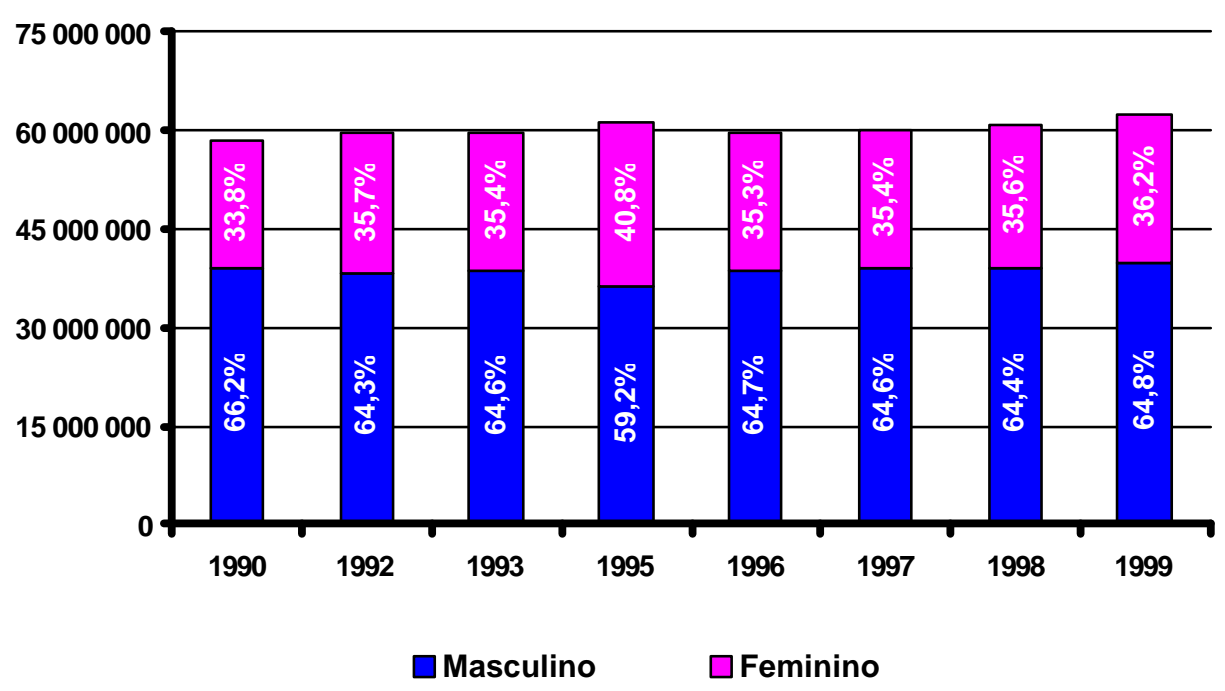

Figura 2 - Mão-de-obra ocupada por gênero no Brasil - 1990/1999.

\footnotetext{
${ }^{5} \mathrm{O}$ anexo mostra os resultados para os 31 setores.
} 
Ao longo da década, a idade do trabalhador ocupado concentra-se na faixa dos 20 a 39 anos. Ao mesmo tempo em que diminuiu a participação da mão-deobra jovem, entre 15 a 19 anos, a ocupação de trabalhadores com idade superior a 50 anos apresentou um pequeno crescimento (figura 3).

Nota-se, assim, uma mudança no comportamento das empresas, as quais vêm caminhando em direção a ocupação de mão-de-obra mais madura.

Isto está de acordo com Amadeo (1998), o qual mostra uma entrada mais tardia dos jovens no mercado de trabalho, ao mesmo tempo em que tem crescido a exigência das empresas por trabalhadores mais experientes e mais qualificados.

Não obstante, dos trabalhadores ocupados na economia na década de 1990, observa-se que a grande maioria ainda começou a trabalhar com 10 a 14 anos (figura 4).

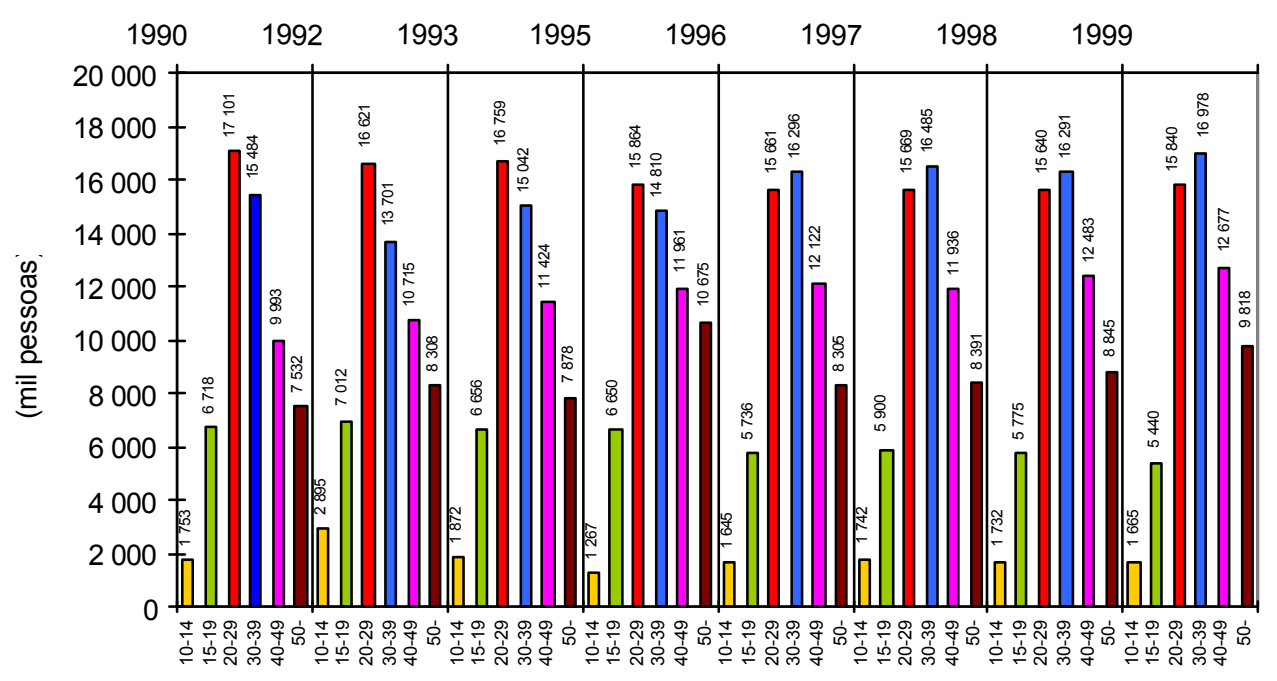

Figura 3 - Idade da mão-de-obra ocupada no Brasil - 1990/1999. 


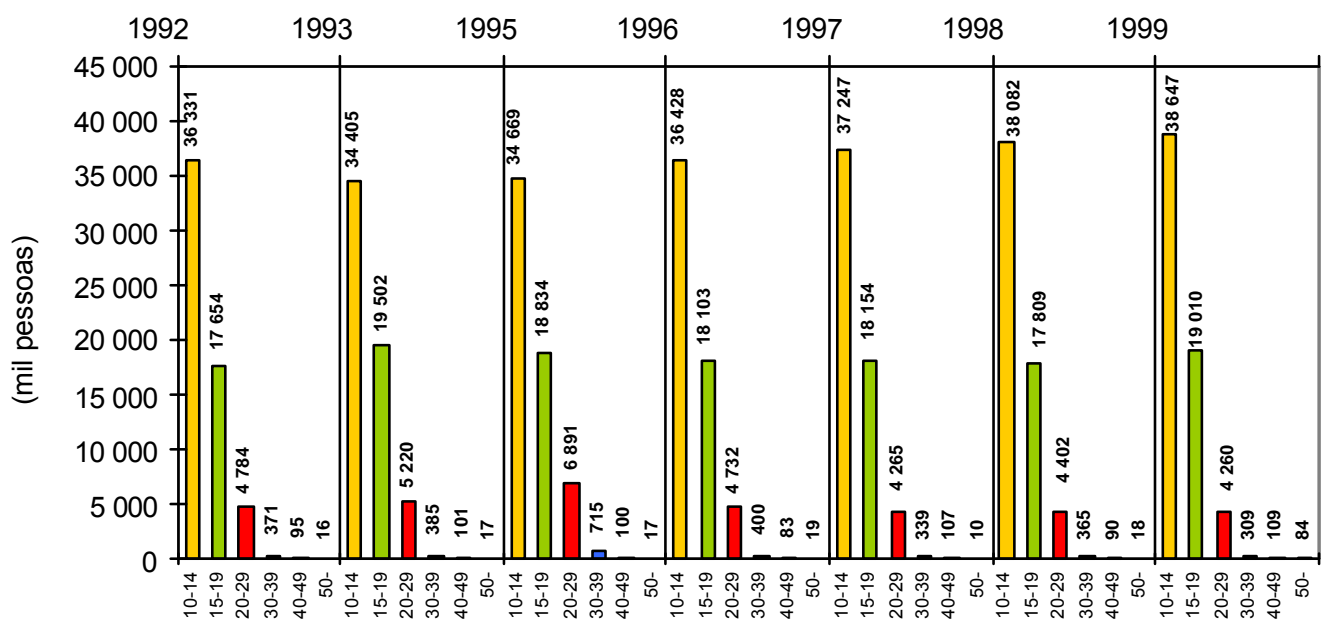

Figura 4 - Idade de ingresso no primeiro trabalho da mão-de-obra ocupada no Brasil $1990 / 1999$.

No que diz respeito a situação na ocupação dos trabalhadores nota-se, principalmente a partir da segunda metade da década, um crescimento do número de trabalhadores sem carteira assinada, indicando uma possível piora nas relações de trabalho, na medida em que o trabalhador fica desprovido de direitos como fundo de garantia, previdência social, adicional de férias, etc. Há também uma redução abrupta no número de pessoas trabalhando por conta própria. e um aumento no número de postos de trabalho na administração pública (figura 5). 


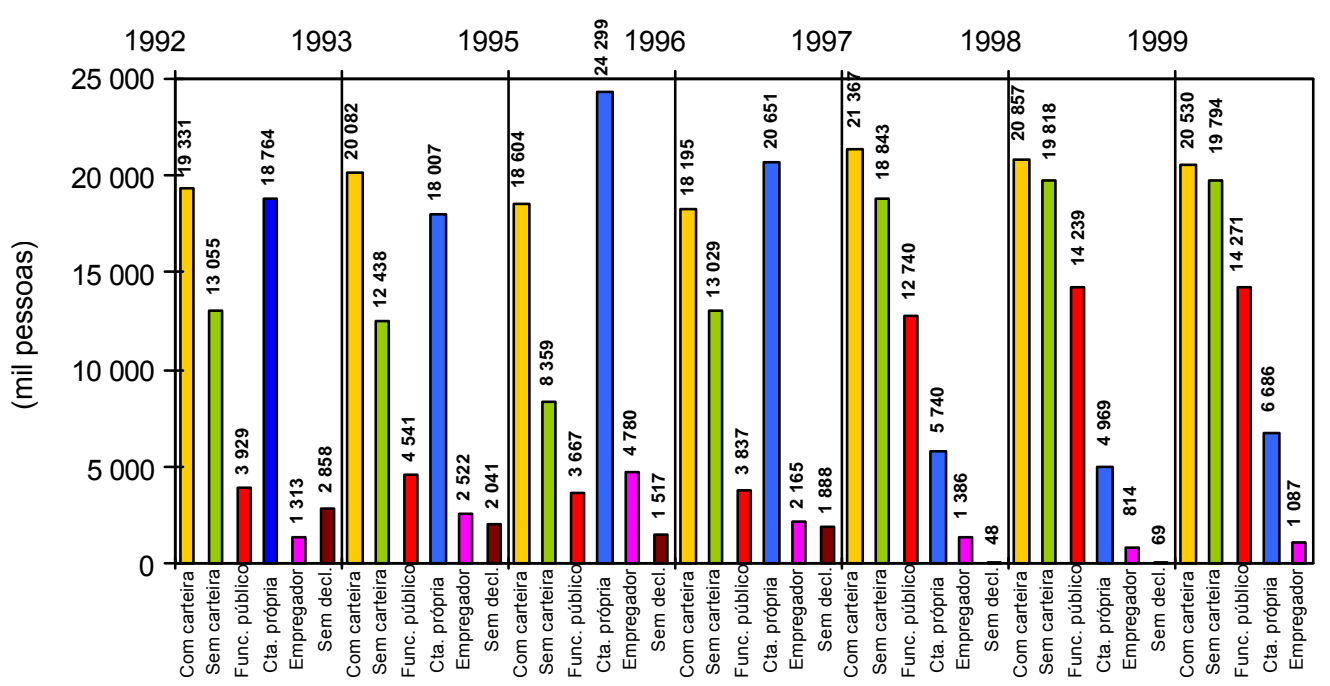

Figura 5 - Situação na ocupação da mão-de-obra no Brasil 1990/1999.

Outro fator que parece indicar a precarização das relações de trabalho é o tempo de serviço da mão-de-obra ocupada. Ao longo da década, algo em torno de $40 \%$ das pessoas estavam no atual emprego entre menos de 1 ano a 2 anos (figura 6). Isto indica que a rotatividade dos trabalhadores no emprego ainda é bastante acentuada.

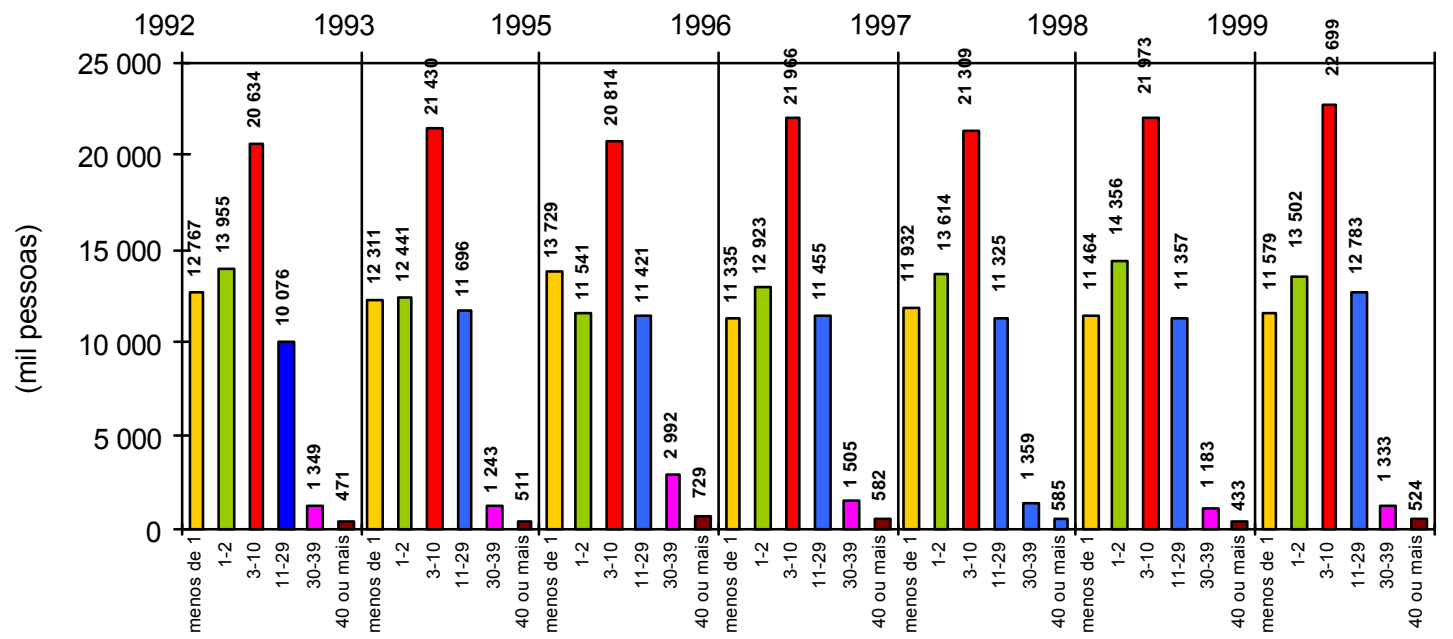

Figura 6 - Tempo de serviço da mão-de-obra ocupada no Brasil - 1990/1999. 
Quanto ao número de horas de trabalho, Foguel (1998, p. 2) afirma que "no caso do Brasil, a jornada de trabalho padrão foi fixada pela Constituição de 1988 em 44 horas semanais, ou 8 horas por dia."

Talvez por conta disto, na década de 1990, o número de horas de trabalho semanais é maior que 45 horas para cerca de $40 \%$ da mão-de-obra ocupada. Ainda assim, mais de $20 \%$, em média, da mão-de-obra ocupada trabalha em tempo parcial, ou seja, menos que 30 horas semanais (figura 7).

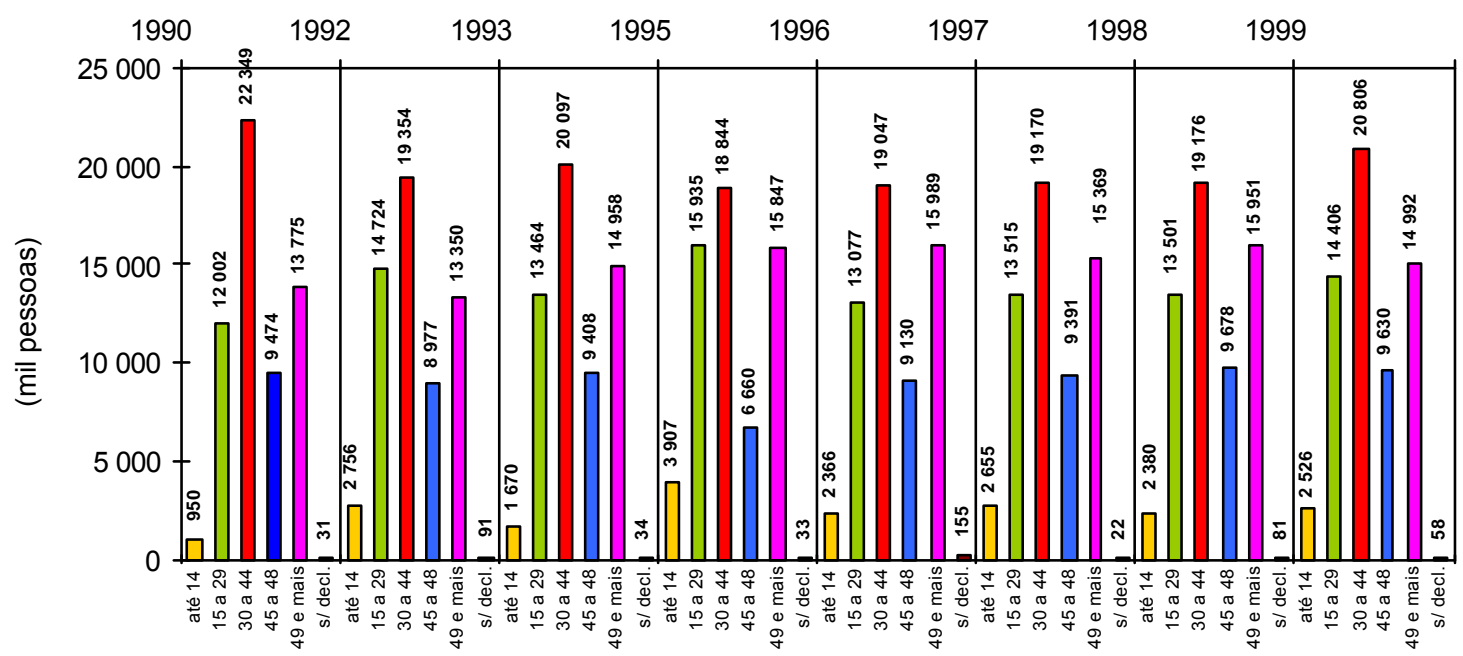

Figura 7 - Jornada de trabalho da mão-de-obra ocupada no Brasil - 1990/1999.

Embora, a partir da segunda metade da década, tenha-se observado um ligeiro crescimento para a escolaridade da mão-de-obra ocupada entre 8 a 14 anos, a maioria dos trabalhadores ocupados durante todo período analisado possui de 4 a 7 anos de estudo (figura 8). Note-se que, conforme já apontado, a média de anos de escolaridade na América Latina é de 8 anos. 


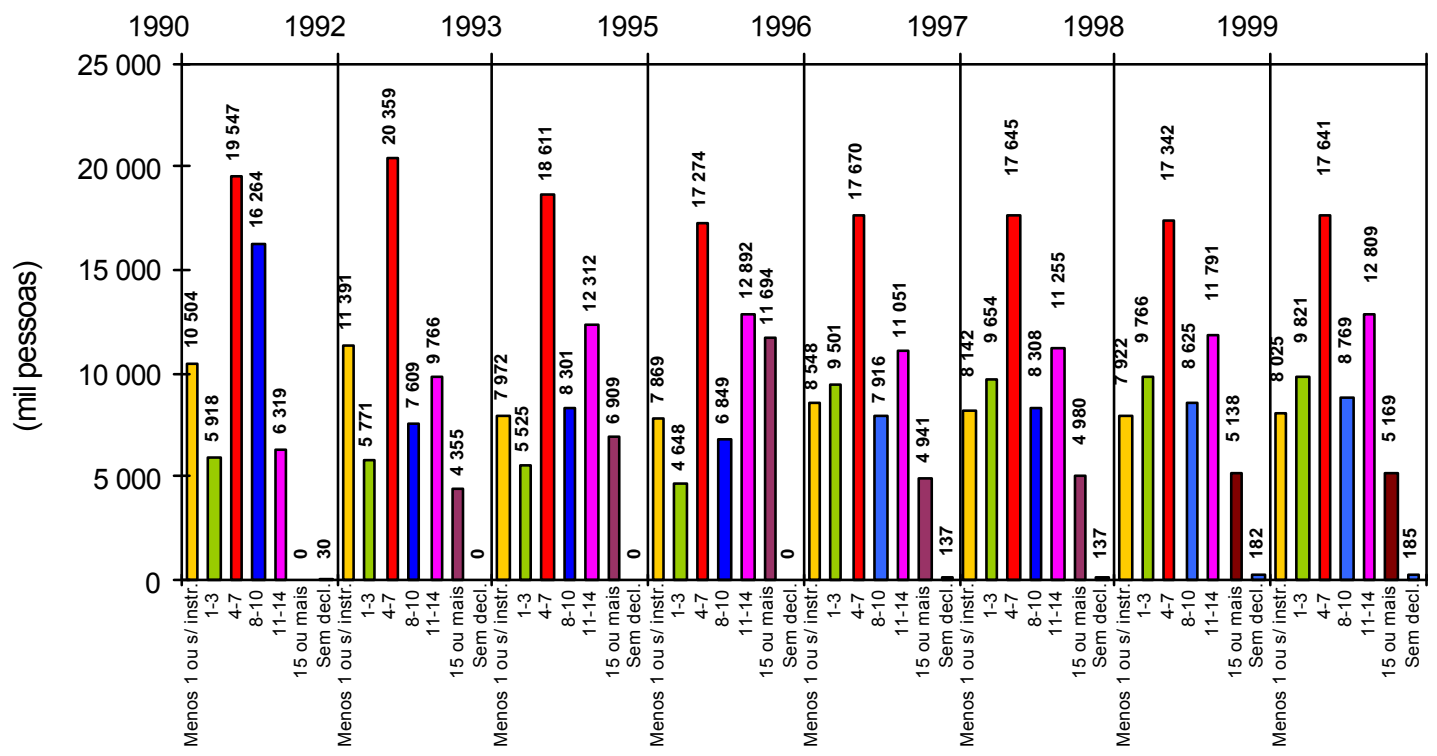

Figura 8 - Número de anos de estudo da mão-de-obra ocupada no Brasil - 1990/1999.

Considerando-se, para efeitos de análise, que os trabalhadores ocupados com menos de um ano até 7 anos de estudo possuem baixa qualificação, que os trabalhadores com 8 a 14 anos de estudo têm média qualificação e que aqueles com mais de 15 anos de estudo tenham alta qualificação, pode-se observar que a maioria da mãode-obra ocupada no Brasil possui baixa qualificação (figura 9).

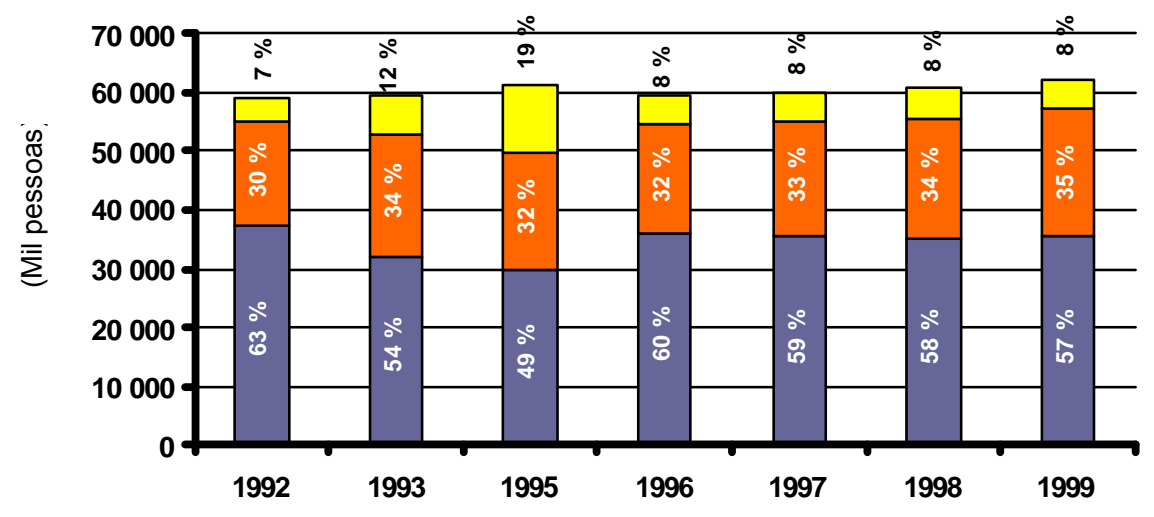

Baixa qualificação $\square$ Média qualificação $\square$ Alta qualificação

Figura 9 - Qualificação da mão-de-obra no Brasil - 1990 - 1999. 
Em resumo, os anos de 1990 mostraram várias mudanças no perfil do trabalhador ocupado. Os dados demonstram que houve um pequeno crescimento no emprego da mão-de-obra feminina em relação ao total dos trabalhadores ocupados. Embora a idade do trabalhador ocupado tenha demonstrado que as empresas estão utilizando mão-de-obra mais madura, o trabalhador ocupado na década de 1990 ingressou cedo no primeiro emprego, embora aqueles que estão ingressando no mercado de trabalho atualmente, o estão fazendo com idade mais elevada. Excetuando-se a Administração Pública, observou-se uma diminuição da ocupação de trabalhadores com carteira assinada, ao mesmo tempo em que se observou uma alta rotatividade. Em todos os anos da década, a maior proporção da mão-de-obra ocupada estava no atual emprego a menos que 2 anos. A escolaridade média da mão-de-obra ocupada cresceu, mas continua baixa.

\subsection{Panorama setorial da mão-de-obra ocupada no Brasil}

A evolução setorial da oferta de postos de trabalho na década de 1990 pode ser observada na tabela 1. Neste período, o setor Agropecuária perdeu aproximadamente 548 mil postos, mesmo tendo apresentado uma recuperação em 1999.

O setor Extrativa mineral (exceto combustíveis) experimentou uma queda contínua de postos de trabalho durante toda a década e o setor Extração de petróleo, gás natural, carvão e outros combustíveis fechou o período com um saldo positivo de 2.900 empregos. No entanto, como estes setores empregam, em relação as demais atividades da economia, um número bastante reduzido de pessoas, sua evolução é pouco significativa para o total da economia.

O setor Indústria ajustou-se de modo bem mais acentuado, fechando a década com um saldo negativo de 1,45 milhões de postos de trabalho. Neste macro setor, Fabricação de artigos de vestuário e acessórios foi o que mais diminuiu postos de trabalho (aproximadamente 227 mil), seguido pelo setor Siderurgia, metais não ferrosos e outros produtos metalúrgicos (187 mil postos a menos).

A redução do número de postos de trabalho no setor Indústria foi mais acentuada na segunda metade da década, refletindo, de algum modo, as mudanças no processo produtivo ocorridas neste período. 
Tabela 1 - Número de pessoas ocupadas por macro setor - 1990 - 1999.

\begin{tabular}{lrrrrrrrrrr}
\hline Macro - setores & 1990 & 1991 & 1992 & 1993 & 1994 & 1995 & 1996 & 1997 & 1998 & 1999 \\
\hline Agropecuária & 14.911 .400 & 15.268 .200 & 15.642 .100 & 15.571 .600 & 15.365 .300 & 15.163 .000 & 13.905 .800 & 13.679 .000 & 13.292 .900 & 14.363 .400 \\
Extrativa mineral (exc.combustíveis) & 301.200 & 278.400 & 261.100 & 268.200 & 246.700 & 230.300 & 206.600 & 205.000 & 207.700 & 189.600 \\
Ext. de petróleo, gás nat.,carvão e outros & & & & & & & & & \\
comb. & 34.100 & 33.400 & 32.700 & 29.600 & 30.100 & 30.700 & 26.300 & 24.900 & 27.200 & 37.000 \\
Indústria & 9.089 .500 & 8.636 .400 & 8.247 .700 & 8.263 .300 & 8.326 .500 & 8.291 .600 & 7.994 .200 & 7.805 .300 & 7.629 .500 & 7.640 .900 \\
Serviços industrias de utilidade pública & 324.000 & 306.900 & 290.700 & 315.100 & 283.500 & 255.100 & 232.100 & 233.900 & 238.000 & 215.500 \\
Construção civil & 3.936 .000 & 3.681 .800 & 3.451 .200 & 3.550 .300 & 3.484 .100 & 3.429 .400 & 3.523 .000 & 3.700 .800 & 4.036 .000 & 3.908 .800 \\
Serviços & 29.984 .600 & 30.826 .300 & 31.326 .000 & 31.632 .200 & 32.670 .700 & 33.826 .000 & 33.876 .600 & 34.474 .000 & 35.335 .400 & 36.063 .700 \\
TOTAL & 58.580 .800 & 59.031 .400 & 59.251 .500 & 59.630 .300 & 60.406 .900 & 61.226 .100 & 59.764 .600 & 60.122 .900 & 60.766 .700 & 62.418 .900 \\
\hline
\end{tabular}

Fonte: Dados da pesquisa.

Tabela 2 - Variação percentual em relação ao ano anterior das pessoas ocupadas por macro setor - 1991 - 1999.

\begin{tabular}{|c|c|c|c|c|c|c|c|c|c|}
\hline & 1991 & 1992 & 1993 & 1994 & 1995 & 1996 & 1997 & 1998 & 1999 \\
\hline Agropecuária & 2,39 & 2,45 & $-0,45$ & $-1,32$ & $-1,32$ & $-8,29$ & $-1,63$ & $-2,82$ & 8,05 \\
\hline Extrativa mineral (exc. combustíveis) & $-7,57$ & $-6,21$ & 2,72 & $-8,02$ & $-6,65$ & $-10,29$ & $-0,77$ & 1,32 & $-8,71$ \\
\hline Ext. de petróleo, gás nat.,carvão e outros comb. & $-2,05$ & $-2,10$ & $-9,48$ & 1,69 & 1,99 & $-14,33$ & $-5,32$ & 9,24 & 36,03 \\
\hline Indústria & $-4,98$ & $-4,50$ & 0,19 & 0,76 & $-0,42$ & $-3,59$ & $-2,36$ & $-2,25$ & 0,15 \\
\hline Serviços industriais de utilidade de pública & $-5,28$ & $-5,28$ & 8,39 & $-10,03$ & $-10,02$ & $-9,02$ & 0,78 & 1,75 & $-9,45$ \\
\hline Construção civil & $-6,46$ & $-6,26$ & 2,87 & $-1,86$ & $-1,57$ & 2,73 & 5,05 & 9,06 & $-3,15$ \\
\hline Serviços & 2,81 & 1,62 & 0,98 & 3,28 & 3,54 & 0,15 & 1,76 & 2,50 & 2,06 \\
\hline
\end{tabular}

Fonte: Dados da pesquisa. 
O setor Serviços industriais de utilidade pública (atividades de distribuição de energia elétrica, abastecimento de água, saneamento básico, etc.) reduziu em aproximadamente $1 / 3$ a oferta de postos de trabalho. Uma das justificativas para isto pode ser a intensificação do processo de privatização ocorrido neste período.

O setor Construção civil apresentou uma tendência de redução de postos de trabalho na primeira metade da década, mas, a partir daí, iniciou um processo de recuperação responsável por fazer com que o número de postos de trabalho fosse praticamente idêntico ao observado em 1990.

O macro setor Serviços apresentou comportamento contrário aos outros setores, aumentando a oferta de postos de trabalho durante toda a década. No entanto, nem todos os setores que o compõem tiveram este comportamento. $\mathrm{O}$ setor Instituições financeiras foi, em termos absolutos e relativos, o que mais reduziu postos de trabalho, apresentando uma queda na oferta de aproximadamente 303 mil postos de trabalho, o que representou uma diminuição de praticamente $30 \%$ em relação ao início da década. $\mathrm{Na}$ sequiência, em números absolutos, o setor Administração pública reduziu sua oferta em 59 mil postos. No entanto, isto representou uma diminuição de pouco mais de $1 \%$ nos postos de trabalho ofertados.

O setor Serviços prestados as famílias terminou a década com um saldo positivo de quase 2 milhões de postos de trabalho, seguido pelo setor Comércio com aproximadamente 1,7 milhões e Serviços privados não mercantis com 1,5 milhões.

Este movimento indica que os postos de trabalho que deixaram de ser ofertados pela Agropecuária, Indústria e alguns setores do macro setor Serviços foram compensados pelo aumento da oferta de postos de trabalho nos Serviços prestados as famílias, no Comércio e nos Serviços privados não mercantis.

Em termos globais, o balanço na oferta de postos de trabalho foi positivo na década de 1990, tendo sido gerados aproximadamente 3,8 milhões de postos de trabalho. 
Não obstante, isto representa um crescimento médio anual de aproximadamente $0,71 \%$. Tendo-se em conta que a população economicamente ativa cresceu, durante a década em média 2,3\% (Cepal, 2001), o resultado inevitável é o aumento da taxa de desemprego. Somente nas regiões metropolitanas, onde é realizada a pesquisa sobre taxa de desemprego, o número passou de 4,65\% em 1990 para 8,26\% em 1999 (IPEADATA, 2002).

Os mesmos resultados, em termos relativos, podem ser observados na tabela 2 e na figura 10.

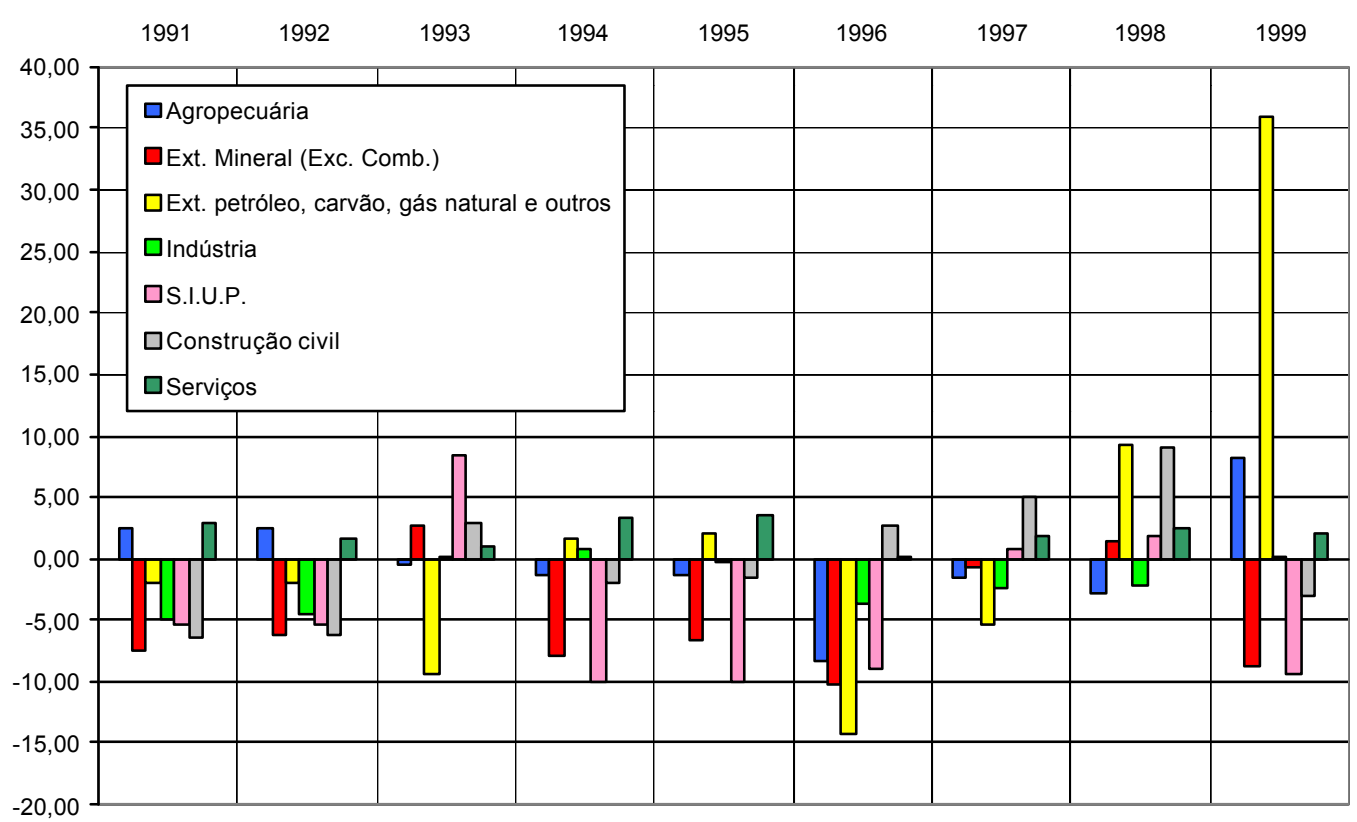

Figura 10 - Variação percentual em relação ao ano anterior do número de pessoas empregadas.

O crescimento contínuo da oferta de postos de trabalho no setor Serviços durante toda a década de 1990 pode ser decorrente da reestruturação na forma de produzir em toda a economia.

Tal reestruturação pode ser parcialmente avaliada pelo comportamento da produtividade aparente dos setores neste período. Todos os macro setores apresentaram 
ganhos consideráveis de produtividade, quando comparados aos níveis do início da década. (tabelas 3 e 4 ).

O setor Agropecuária apresentou nos anos de 1994 a 1996 seus maiores aumentos de produtividade. Aparentemente, este setor modernizou sua produção por meio de uma maior intensificação do uso de capital, diminuindo, em contrapartida, sua capacidade de ofertar novos postos de trabalho.

As variações da produtividade aparente nos setores Extrativa mineral (exceto combustíveis), Extração de petróleo, gás natural, carvão e outros combustíveis e Serviços industriais e utilidade pública tendem a ser maiores, haja vista a alta relação entre o valor adicionado e o número de pessoas ocupadas. Não obstante, estes setores acompanharam o comportamento da produtividade aparente na economia (figura 11).

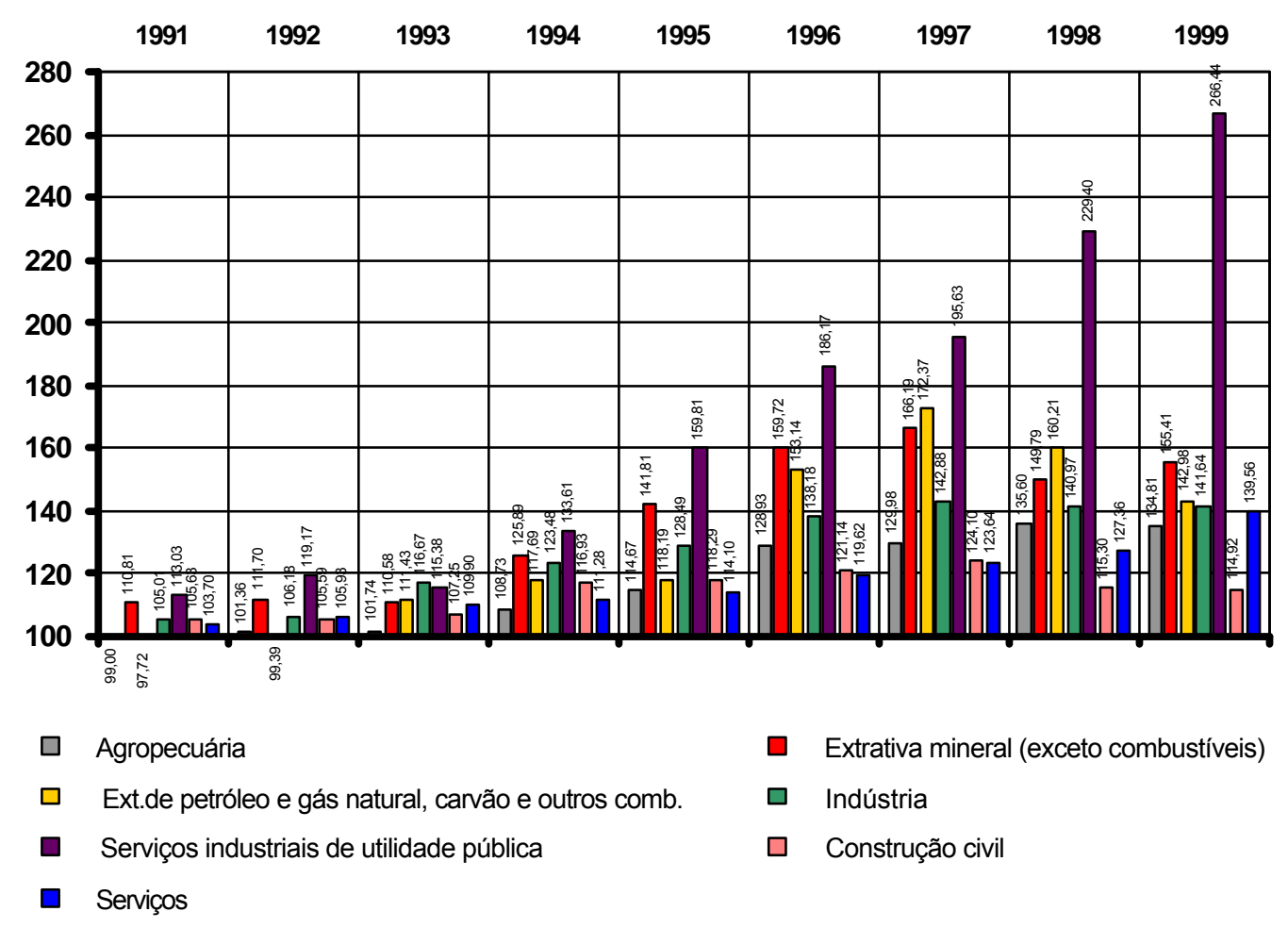

Figura 11 - Variação da produtividade aparente dos macro setores em relação a 1990

$$
(1990=100) .
$$


Tabela 3 - Variação da produtividade aparente dos macro setores em relação a $1990(1990=100)$ - 1991 - 1999.

\begin{tabular}{|c|c|c|c|c|c|c|c|c|c|}
\hline & 1991 & 1992 & 1993 & 1994 & 1995 & 1996 & 1997 & 1998 & 1999 \\
\hline Agropecuária & 99,00 & 101,36 & 101,74 & 108,73 & 114,67 & 128,93 & 129,98 & 135,60 & 134,81 \\
\hline Extrativa mineral (exc. combustíveis) & 110,81 & 111,70 & 110,58 & 125,89 & 141,81 & 159,72 & 166,19 & 149,79 & 155,41 \\
\hline Ext. de petróleo, gás nat.,carvão e outros comb. & 97,72 & 99,39 & 111,43 & 117,69 & 118,19 & 153,14 & 172,37 & 160,21 & 142,98 \\
\hline Indústria & 105,01 & 106,18 & 116,67 & 123,48 & 128,49 & 138,18 & 142,88 & 140,97 & 141,64 \\
\hline Serviços industriais de utilidade de pública & 113,03 & 119,17 & 115,38 & 133,61 & 159,81 & 186,17 & 195,63 & 229,40 & 266,44 \\
\hline Construção civil & 105,63 & 105,59 & 107,25 & 116,93 & 118,29 & 121,14 & 124,10 & 115,30 & 114,92 \\
\hline Serviços & 103,70 & 105,93 & 109,90 & 111,28 & 114,10 & 119,62 & 123,64 & 127,36 & 139,56 \\
\hline
\end{tabular}

Fonte: Dados da pesquisa.

Tabela 4 - Variação percentual em relação ao ano anterior da produtividade aparente dos macro setores - 1991 - 1999.

\begin{tabular}{|c|c|c|c|c|c|c|c|c|c|}
\hline & 1991 & 1992 & 1993 & 1994 & 1995 & 1996 & 1997 & 1998 & 1999 \\
\hline Agropecuária & $-1,00$ & 2,38 & 0,38 & 6,87 & 5,47 & 12,44 & 0,81 & 4,32 & $-0,58$ \\
\hline Extrativa mineral (exc. combustíveis) & 10,81 & 0,81 & $-1,00$ & 13,85 & 12,64 & 12,63 & 4,05 & $-9,87$ & 3,75 \\
\hline Ext. de petróleo, gás nat.,carvão e outros comb. & $-2,28$ & 1,71 & 12,11 & 5,62 & 0,42 & 29,57 & 12,56 & $-7,06$ & $-10,75$ \\
\hline Indústria & 5,01 & 0,96 & 9,46 & 5,46 & 4,01 & 7,22 & 3,10 & $-1,56$ & 1,14 \\
\hline Serviços industriais de utilidade de pública & 13,03 & 5,43 & $-3,18$ & 15,80 & 19,61 & 16,50 & 5,08 & 17,26 & 16,15 \\
\hline Construção civil & 5,63 & $-0,04$ & 1,58 & 9,02 & 1,16 & 2,41 & 2,45 & $-7,09$ & $-0,33$ \\
\hline Serviços & 3,72 & 1,73 & 3,85 & 1,69 & 1,91 & 4,29 & 2,71 & 0,40 & 2,79 \\
\hline
\end{tabular}

Fonte: Dados da pesquisa. 
A produtividade no setor Indústria cresceu durante praticamente toda a década. Apenas no ano de 1998 ela apresentou uma pequena queda, o que demonstra o esforço de adequação deste setor às novas condições de competição vigentes na economia.

Embora a variação da produtividade aparente do macro setor Serviços seja relativamente menor que a apresentada pelos outros setores, ela é constante durante todo o período. $\mathrm{O}$ crescimento da produtividade deste macro setor deve-se, basicamente, ao crescimento do setor Comunicações, que aumentou sua produtividade em aproximadamente $47 \%$ em relação a 1990. Com exceção deste setor, apenas o setor Serviços prestados às empresas e o setor Administração pública apresentaram maiores níveis de produtividade no ano de 1999, embora tais níveis representaram apenas um modesto aumento de $4,4 \%$ e $1 \%$, respectivamente.

\subsection{Participação dos componentes da demanda total na oferta de postos de trabalho}

Conforme já apontado, uma das hipóteses básicas de um modelo de insumo-produto é que os coeficientes técnicos são fixos para cada período específico. Logo, um aumento na produção de um determinado setor exigirá um aumento correspondente na quantidade de insumos.

O mesmo vale para o número de pessoas ocupadas em cada setor. Dado que também neste caso não há economias de escala, quanto maior for a produção de um setor, maior será o número de trabalhadores necessário.

Deste modo, quando há uma alteração, tanto na demanda por bens intermediários, quanto na demanda final e nas exportações, haverá uma alteração correspondente na oferta de postos de trabalho.

Assumindo-se que o emprego em cada um dos setores é distribuído na proporção correspondente ao produto do setor no consumo doméstico, consumo intermediário e exportação, pode-se calcular o quanto cada um destes componentes participa na geração de empregos na economia. 
Na década de 1990, o consumo intermediário foi responsável, em média, por $53 \%$ da oferta de postos de trabalho (tabela $5 \mathrm{a}, 5 \mathrm{~b}$ e figura 12 ).

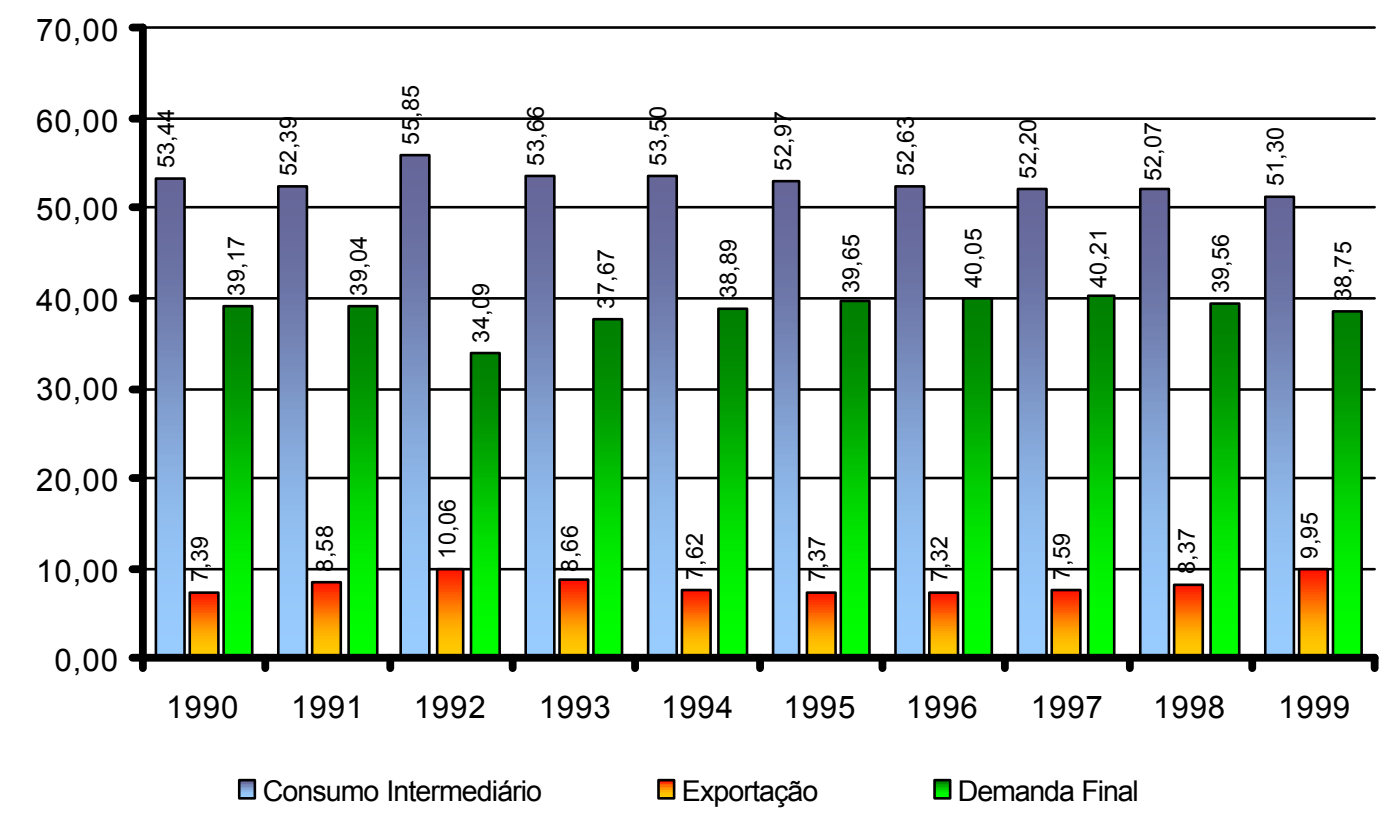

Figura 12 - Participação dos componentes da demanda total na oferta de postos de trabalho - $1990-1999$.

Dos trinta e um setores analisados, dezoito têm no consumo intermediário o principal componente na oferta de postos de trabalho durante todo o período. No caso do setor Extração de petróleo, gás natural, carvão mineral e outros combustíveis, este valor chega a 98,7\%, em média. Os setores Fabricação de minerais não metálicos, Indústria da borracha, Refino de petróleo e indústria petroquímica, e Serviços prestados as empresas apresentaram uma taxa média de $89 \%$. 
Tabela 5a. Participação dos componentes da demanda total na oferta de postos de trabalho.

\begin{tabular}{|c|c|c|c|c|c|c|c|c|c|c|c|c|c|c|c|}
\hline & \multicolumn{3}{|c|}{1990} & \multicolumn{3}{|c|}{1991} & \multicolumn{3}{|c|}{1992} & \multicolumn{3}{|c|}{1993} & \multicolumn{3}{|c|}{1994} \\
\hline & $\begin{array}{l}\text { Cons. } \\
\text { Interm. }\end{array}$ & $\begin{array}{l}\text { Dem. } \\
\text { Final }\end{array}$ & Export. & $\begin{array}{l}\text { Cons. } \\
\text { Interm. }\end{array}$ & $\begin{array}{l}\text { Dem. } \\
\text { Final }\end{array}$ & Export. & $\begin{array}{l}\text { Cons. } \\
\text { Interm. }\end{array}$ & $\begin{array}{l}\text { Dem. } \\
\text { Final }\end{array}$ & Export. & $\begin{array}{l}\text { Cons. } \\
\text { Interm. }\end{array}$ & $\begin{array}{l}\text { Dem. } \\
\text { Final }\end{array}$ & Export. & $\begin{array}{l}\text { Cons. } \\
\text { Interm. }\end{array}$ & $\begin{array}{l}\text { Dem. } \\
\text { Final }\end{array}$ & Export. \\
\hline Agropecuária & 59,54 & 37,74 & 2,72 & 60,40 & 37,50 & 2,10 & 62,05 & 34,96 & 2,99 & 64,83 & 32,34 & 2,83 & 61,56 & 35,49 & 2,95 \\
\hline Extrativa mineral (exc. combustíveis) & 59,33 & $-0,60$ & 41,27 & 51,42 & $-0,72$ & 49,30 & 49,34 & 2,58 & 48,08 & 55,65 & $-2,59$ & 46,94 & 56,65 & 2,83 & 40,52 \\
\hline Ext. de petróleo, gás nat.,carvão e outros comb. & 94,33 & 5,58 & 0,09 & 94,43 & 5,44 & 0,13 & 99,43 & 0,42 & 0,15 & 101,91 & $-1,93$ & 0,02 & 103,34 & $-3,36$ & 0,02 \\
\hline Indústria & 46,07 & 48,13 & 5,80 & 44,06 & 49,20 & 6,74 & 44,45 & 46,44 & 9,11 & 43,14 & 47,64 & 9,22 & 42,17 & 49,68 & 8,15 \\
\hline Serviços industriais de utilidade de pública & 71,56 & 28,44 & 0,01 & 75,25 & 24,75 & 0,01 & 69,80 & 30,18 & 0,01 & 70,06 & 29,92 & 0,02 & 69,46 & 30,52 & 0,02 \\
\hline Construção civil & 10,57 & 89,43 & 0,00 & 9,90 & 90,10 & 0,00 & 10,01 & 89,99 & 0,00 & 9,87 & 90,13 & 0,00 & 9,90 & 90,10 & 0,00 \\
\hline Serviços & 32,69 & 65,46 & 1,85 & 31,24 & 67,00 & 1,76 & 30,10 & 68,21 & 1,69 & 30,20 & 68,20 & 1,60 & 31,40 & 66,93 & 1,67 \\
\hline
\end{tabular}

Fonte: Dados da pesquisa.

Tabela 5b. Participação dos componentes da demanda total na oferta de postos de trabalho.

\begin{tabular}{|c|c|c|c|c|c|c|c|c|c|c|c|c|c|c|c|}
\hline & \multicolumn{3}{|c|}{1995} & \multicolumn{3}{|c|}{1996} & \multicolumn{3}{|c|}{1997} & \multicolumn{3}{|c|}{1998} & \multicolumn{3}{|c|}{1999} \\
\hline & $\begin{array}{l}\text { Cons. } \\
\text { Interm. }\end{array}$ & $\begin{array}{l}\text { Dem. } \\
\text { Final }\end{array}$ & Export. & $\begin{array}{l}\text { Cons. } \\
\text { Interm. }\end{array}$ & $\begin{array}{l}\text { Dem. } \\
\text { Final }\end{array}$ & Export. & $\begin{array}{l}\text { Cons. } \\
\text { Interm. }\end{array}$ & $\begin{array}{l}\text { Dem. } \\
\text { Final }\end{array}$ & Export. & $\begin{array}{l}\text { Cons. } \\
\text { Interm. }\end{array}$ & $\begin{array}{l}\text { Dem. } \\
\text { Final }\end{array}$ & Export. & $\begin{array}{l}\text { Cons. } \\
\text { Interm. }\end{array}$ & $\begin{array}{l}\text { Dem. } \\
\text { Final }\end{array}$ & Export. \\
\hline Agropecuária & 63,80 & 34,57 & 1,64 & 66,50 & 31,67 & 1,83 & 64,69 & 32,01 & 3,31 & 63,76 & 33,20 & 3,04 & 61,56 & 34,95 & 3,49 \\
\hline Extrativa mineral (exc. combustíveis) & 57,16 & 5,11 & 37,73 & 57,77 & 3,54 & 38,69 & 56,06 & 3,94 & 40,00 & 54,78 & 0,71 & 44,51 & 50,96 & $-2,38$ & 51,42 \\
\hline Ext. de petróleo, gás nat.,carvão e outros comb. & 100,93 & $-2,17$ & 1,24 & 96,99 & 2,79 & 0,22 & 98,31 & 1,62 & 0,08 & 98,31 & 1,48 & 0,21 & 99,08 & 0,88 & 0,03 \\
\hline Indústria & 43,36 & 47,53 & 9,10 & 43,67 & 47,39 & 8,95 & 42,57 & 49,95 & 7,49 & 42,37 & 49,52 & 8,10 & 42,05 & 46,92 & 11,03 \\
\hline Serviços industriais de utilidade de pública & 68,03 & 31,93 & 0,04 & 66,96 & 33,03 & 0,01 & 66,07 & 33,91 & 0,02 & 67,58 & 32,37 & 0,05 & 68,07 & 31,90 & 0,02 \\
\hline Construção civil & 9,82 & 90,18 & 0,00 & 9,40 & 90,60 & 0,00 & 9,12 & 90,88 & 0,00 & 9,13 & 90,82 & 0,05 & 9,46 & 90,52 & 0,02 \\
\hline Serviços & 27,72 & 70,40 & 1,88 & 27,10 & 71,35 & 1,56 & 28,58 & 69,14 & 2,28 & 28,52 & 68,83 & 2,65 & 27,93 & 68,42 & 3,65 \\
\hline
\end{tabular}

Fonte: Dados da pesquisa. 
A demanda final foi significativa em onze setores. O setor Serviços privados não mercantis depende integralmente deste componente, isto é, em todo período analisado a taxa foi de $100 \%$. O setor Fabricação de artigos do vestuário e acessórios apresentou uma taxa média de aproximadamente $95 \%$ no período e os setores Construção civil e Administração pública apresentaram taxas médias de aproximadamente $90 \%$ e 92\%, respectivamente. A característica em comum destes setores é que nenhum outro setor compra diretamente deles, isto é, toda sua produção é destinada para o consumo final, ou, no caso da Construção civil para o investimento.

Poucos são os setores que possuem a exportação com maior participação na oferta de postos de trabalho. A parcela da demanda total destinada para o exterior permite avaliar o grau de internacionalização da economia.

No que se refere aos postos de trabalho, o setor Extrativa mineral (exceto combustíveis) é o único com esta característica. Neste setor, as exportações corresponderam, em média, a $44 \%$ dos postos de trabalho ofertados.

No setor Fabricação de calçados e artigos em couro, embora a demanda final tenha sido a principal responsável pela oferta de postos de trabalho (49\%), as exportações desempenharam um importante papel, apresentando, em média, uma participação de 32\% na década de 1990.

\subsection{Perfil da mão-de-obra ocupada nos macro setores}

Conforme mostrado anteriormente, a década de 1990 apresentou várias mudanças na estrutura da oferta de postos de trabalho e no perfil da mão-de-obra ocupada no Brasil.

As sete sub-seções seguintes nostram a evolução do perfil da mão-deobra ocupada em cada um dos macro setores da economia. 


\subsubsection{Agropecuária}

Nos anos 1990, o setor Agropecuária foi responsável, em média, pela oferta de $24 \%$ dos postos de trabalho na economia. Neste setor predomina a ño-deobra masculina, dado que a mão-de-obra feminina ocupada correspondeu, em média, a $15,9 \%$ do total empregado no setor (Quadro 2). Em relação ao total de mulheres empregadas na economia nos anos 1990, este setor absorve cerca de 10\% delas .

A idade predominante da mão-de-obra ocupada neste setor está na faixa dos 20 a 39 anos (Quadro 2). Este intervalo concentra aproximadamente 47\% dos trabalhadores, seguindo de perto a média nacional que é de 53\%. O setor é o maior absorvedor da mão-de-obra na faixa dos 10 a 14 anos. A média nacional é de 3\%, enquanto na Agropecuária a média do período foi de 5,8\%.

Dada a maior concentração de jovens neste setor, é natural que a idade de ingresso no primeiro trabalho concentre-se na faixa entre 10 a 14 anos. De fato, cerca de $78 \%$ dos trabalhadores empregados no setor iniciaram nesta faixa etária, enquanto a média nacional para este intervalo é de aproximadamente 60\% (Quadro 2).

A situação na ocupação da mão-de-obra no setor mostrou uma pequena redução da participação dos trabalhadores com carteira assinada. Enquanto em 1992 eles correspondiam a 13,13 \%, em 1999 representavam apenas 10,14\% da mão-de-obra ocupada. A mão-de-obra por conta própria também diminuiu de 53,72\% em 1992 para 13,76\% em 1999. Ao mesmo tempo, a mão-de-obra ocupada sem carteira assinada aumentou de 18,43\% em 1990 para 44,29\% em 1999. Isto parece demonstrar que, tal como no restante da economia, houve uma precarização as relações de trabalho no setor.

Dos trabalhadores ocupados no setor, cerca de $1 / 3$, em média, estava no atual emprego no máximo a 2 anos (Quadro 2), indicando uma elevada rotatividade neste período.

A jornada de trabalho (horas semanais) acompanha a média nacional. Cerca de $39 \%$ dos trabalhadores ocupados trabalham mais que 45 horas. No entanto, o setor é o que mais utiliza mão-de-obra em tempo parcial. Enquanto a média da economia 
para jornadas inferiores a 30 horas é $26,95 \%$, cerca de $42 \%$ da mão-de-obra ocupada neste setor estava nesta categoria (Quadro 2).

A escolaridade dos trabalhadores ocupados neste setor é menor que a média nacional. Considerando a média do período, mais de $85 \%$ da mão-de-obra possui no máximo 7 anos de estudo. Aproximadamente $1 / 3$ dos trabalhadores possui menos que um ano de estudo.

\begin{tabular}{|c|c|c|c|}
\hline Gênero & & Tempo de serviço & \\
\hline - Masculino & 84,10 & - Menos de 1 ano & 16,14 \\
\hline - Feminino & 15,90 & - 1 a 2 anos & 15,92 \\
\hline Idade & & - 3 a 10 anos & 36,15 \\
\hline - 10 a 14 anos & 5,85 & - 11 a 29 anos & 24,28 \\
\hline - 15 a 19 anos & 13,88 & - 30 a 39 anos & 5,50 \\
\hline - 20 a 29 anos & 24,96 & - 40 anos ou mais & 2,02 \\
\hline - 30 a 39 anos & 22,68 & & \\
\hline - 40 a 49 anos & 17,80 & & \\
\hline - 50 anos ou mais & 14,83 & & \\
\hline Idade de ingresso no primeiro trak & & Jornada de trabalho (horas sema & \\
\hline - 10 a 14 anos & 78,43 & - Até 14 horas & 7,57 \\
\hline - 15 a 19 anos & 17,58 & - 15 a 29 horas & 34,98 \\
\hline - 20 a 29 anos & 3,63 & - 30 a 44 horas & 22,39 \\
\hline - 30 a 39 anos & 0,36 & - 45 a 48 horas & 18,82 \\
\hline - 40 anos ou mais & 0,01 & - 49 horas ou mais & 20,30 \\
\hline & & - Sem declaração & 0,26 \\
\hline Situação da ocupação & & Anos de estudo & \\
\hline - Empregado com carteira & 11,97 & - Menos de 1 ano e sem instrução & 33,70 \\
\hline - Empregado sem carteira & 28,26 & - $\quad 1$ a 3 anos & 22,74 \\
\hline - Funcionário público & 11,49 & - 4 a 7 anos & 29,82 \\
\hline - Conta própria & 38,19 & - 8 a 10 anos & 5,62 \\
\hline - Empregador & 5,67 & - 11 a 14 anos & 4,43 \\
\hline - Não remuner. ou sem declaração & 4,41 & - 15 anos ou mais & 3,62 \\
\hline & & - Sem declaração & 0,07 \\
\hline
\end{tabular}

Quadro 2 - Perfil da mão-de-obra ocupada no setor Agropecuária (percentual médio na década). 


\subsubsection{Extrativa mineral (exceto combustíveis)}

Este setor foi responsável, em média, por menos de $0,5 \%$ da oferta de postos de trabalho. A participação da mão-de-obra feminina foi reduzida, representando, em média, menos que $7 \%$ do total (Quadro 3). Dado que este setor é pouco representativo na oferta total de postos de trabalho na economia, a absorção da mão-deobra feminina é desprezível $(0,07 \%)$.

Este setor pode ser classificado como típico, no que se refere a idade do trabalhador, tendo em vista que a distribuição da força de trabalho acompanha a média nacional para a década de 1990.

A situação na ocupação também segue a média nacional, exceto pelo fato de que os trabalhadores classificados como Empregadores, participaram, em média, com 7,28 \% da mão-de-obra ocupada, enquanto que a média nacional, para o mesmo período foi de $3,32 \%$.

A rotatividade da mão-de-obra neste setor é elevada. Aproximadamente $46 \%$, em média, dos trabalhadores estava no emprego a menos de 2 anos, enquanto a média nacional na década foi de $42 \%$.

A jornada de trabalho média na década foi ligeiramente inferior a média nacional. Cerca de $37 \%$ cumprem uma jornada maior que 45 horas semanais.

A escolaridade do trabalhador neste setor é menor que a média nacional. Mais de $83 \%$ da mão-de-obra ocupada tem uma escolaridade igual ou menor a 7 anos. 


\begin{tabular}{|c|c|c|c|}
\hline \multicolumn{2}{|l|}{ Gênero } & \multicolumn{2}{|l|}{ Tempo de serviço } \\
\hline - Masculino & 93,21 & - Menos de 1 ano & 24,13 \\
\hline - Feminino & 6,79 & - 1 a 2 anos & 21,81 \\
\hline \multicolumn{2}{|l|}{ Idade } & - 3 a 10 anos & 35,88 \\
\hline - 10 a 14 anos & 3,72 & - 11 a 29 anos & 16,73 \\
\hline - 15 a 19 anos & 10,73 & - 30 a 39 anos & 1,15 \\
\hline - 20 a 29 anos & 28,26 & - 40 anos ou mais & 0,30 \\
\hline - 30 a 39 anos & 27,27 & & \\
\hline - 40 a 49 anos & 16,06 & & \\
\hline - 50 anos ou mais & 13,96 & & \\
\hline \multicolumn{2}{|c|}{ Idade de ingresso no primeiro trabalho } & \multicolumn{2}{|c|}{ Jornada de trabalho (horas semanais) } \\
\hline - 10 a 14 anos & 75,19 & - Até 14 horas & 4,27 \\
\hline - 15 a 19 anos & 21,59 & - 15 a 29 horas & 25,83 \\
\hline - 20 a 29 anos & 3,03 & - 30 a 44 horas & 33,21 \\
\hline - 30 a 39 anos & 0,20 & - 45 a 48 horas & 18,28 \\
\hline \multirow[t]{2}{*}{ - 40 anos ou mais } & 0,00 & - 49 horas ou mais & 18,78 \\
\hline & & - Sem declaração & 0,00 \\
\hline \multicolumn{2}{|l|}{ Situação na ocupação } & \multicolumn{2}{|l|}{ Anos de estudo } \\
\hline - Empregado com carteira & 34,80 & - Menos de 1 ano e sem instrução & 29,02 \\
\hline - Empregado sem carteira & 23,10 & - 1 a 3 anos & 20,36 \\
\hline - Funcionário público & 14,67 & - 4 a 7 anos & 33,70 \\
\hline - Conta própria & 17,02 & - 8 a 10 anos & 6,86 \\
\hline - Empregador & 7,28 & - 11 a 14 anos & 7,57 \\
\hline \multirow[t]{2}{*}{ - Não remuner. ou sem declaração } & 3,13 & - 15 anos ou mais & 2,50 \\
\hline & & - Sem declaração & 0,00 \\
\hline
\end{tabular}

Quadro 3 - Perfil da mão-de-obra ocupada no setor Extrativa mineral (exceto combustíveis) - percentual médio na década.

\subsubsection{Extração de petróleo, gás natural, carvão e outros combustíveis}

Este setor também é pouco representativo na oferta de postos de trabalho na economia. Em média, ofertou no período em análise $0,05 \%$ do total. A mão-de-obra masculina representa mais que $90 \%$ do total empregado (Quadro 4).

A dispersão da idade dos trabalhadores deste setor parece ser menor que a média nacional. Enquanto o emprego de trabalhadores na faixa etária até 19 anos é de $13,38 \%$ para o total da economia, neste setor ele é de 2,68\%. A maior concentração de trabalhadores neste setor está na faixa de 20 a 39 anos, superando, inclusive, a média nacional (Quadro 4). Os trabalhadores com 40 anos ou mais também são empregados em 
maior proporção que o observado na economia. Logo, pode-se inferir que este setor concentra o emprego da mão-de-obra mais madura.

A idade de ingresso no primeiro trabalho da mão-de-obra ocupada neste setor é mais elevada que a média da economia. Cerca de $45 \%$ dos trabalhadores ingressaram no primeiro trabalho entre 15 a 19 anos, enquanto que em toda economia este percentual é de aproximadamente 30\%. O mesmo se observa na faixa seguinte. Cerca de $19 \%$ dos trabalhadores no setor iniciaram no primeiro trabalho entre 20 e 29 anos, representando uma proporção quase que duas vezes e meia a média nacional.

O setor se destaca na participação dos trabalhadores com carteira assinada, os quais representam mais de $84 \%$ do total da mão-de-obra ocupada. Isto representa um percentual mais que duas vezes e meia maior que a média da economia.

Além disso, observa-se também uma maior estabilidade da mão-de-obra ocupada, dado que, em média, o tempo de serviço de 41,27\% dos trabalhadores estava na faixa de 11 a 29 anos.

A jornada de trabalho predominante no setor é de 30 a 44 horas semanais, menor que a observada na economia.

O setor apresenta o menor percentual da mão-de-obra ocupada com menos de um ano de instrução. A maior concentração está na faixa dos 11 a 14 anos de estudo. O setor é o maior empregador de mão-de-obra com 15 anos de estudo ou mais.

Em linhas gerais, este setor parece ser caracterizado por um alto nível de especialização em relação ao restante da economia, pois o rabalhador típico do setor iniciou mais tarde no primeiro trabalho, conseqüentemente possui uma média de idade mais elevada, tem maior número de anos de estudo e ao mesmo tempo permanece mais tempo no emprego, tendo seus direitos trabalhistas assegurados. 


\begin{tabular}{|c|c|c|c|}
\hline Gênero & & Tempo de serviço & \\
\hline - Masculino & 90,66 & - Menos de 1 ano & 9,14 \\
\hline - Feminino & 9,34 & - 1 a 2 anos & 13,60 \\
\hline Idade & & - 3 a 10 anos & 35,23 \\
\hline - 10 a 14 anos & 0,24 & - 11 a 29 anos & 41,27 \\
\hline - 15 a 19 anos & 2,44 & - 30 a 39 anos & 0,77 \\
\hline - 20 a 29 anos & 18,80 & - 40 anos ou mais & 0,00 \\
\hline - 30 a 39 anos & 43,31 & & \\
\hline - 40 a 49 anos & 28,58 & & \\
\hline - 50 anos ou mais & 6,64 & & \\
\hline Idade de ingresso no primeiro trab & & Jornada de trabalho (horas sema & \\
\hline - 10 a 14 anos & 36,00 & - Até 14 horas & 2,81 \\
\hline - 15 a 19 anos & 44,90 & - 15 a 29 horas & 22,42 \\
\hline - 20 a 29 anos & 18,94 & - 30 a 44 horas & 42,25 \\
\hline - 30 a 39 anos & 0,00 & - 45 a 48 horas & 19,79 \\
\hline - 40 anos ou mais & 0,16 & - 49 horas ou mais & 12,35 \\
\hline & & - Sem declaração & 0,15 \\
\hline Situação na ocupação & & Anos de estudo & \\
\hline - Empregado com carteira & 84,56 & - Menos de 1 ano e sem instrução & 2,24 \\
\hline - Empregado sem carteira & 2,15 & - 1 a 3 anos & 5,10 \\
\hline - Funcionário público & 12,47 & - $\quad 4$ a 7 anos & 14,31 \\
\hline - Conta própria & 0,28 & - 8 a 10 anos & 19,14 \\
\hline - Empregador & 0,38 & - 11 a 14 anos & 36,20 \\
\hline - Não remuner. ou sem declaração & 0,16 & - 15 anos ou mais & 23,01 \\
\hline & & - Sem declaração & 0,00 \\
\hline
\end{tabular}

Quadro 4 - Perfil da mão-de-obra ocupada no setor Extração de petróleo, gás natural, carvão e outros combustíveis (percentual médio na década).

\subsubsection{Indústria}

Este macro setor foi responsável, em média, pela oferta de cerca de $13 \%$ de postos de trabalho na década de 1990. Contudo, o setor perdeu parte de sua importância relativa. No início do período, ele representava $15,5 \%$ do total da oferta de postos de trabalho e em 1999 esta participação caiu para 12,2\%.

Dentre os 17 setores que o compõem, apenas quatro fecharam a década com saldo positivo, isto é, não perderam postos de trabalho. Somados, o saldo dos setores Fabricação de produtos farmacêuticos e de perfumaria, Indústria de transformação de material plástico, Indústria de alimentos em geral e Indústrias diversas, foi de 34.500 postos adicionais. 
Os setores que mais empregaram trabalhadores na década foram, pela ordem, Fabricação de artigos do vestuário e acessórios, Indústria de alimentos em geral, Serrarias e fabricação de artigos de madeira e mobiliário e Siderurgia, metais não ferrosos e outros produtos metalúrgicos, responsáveis, considerando a média do período, respectivamente por $18,9 \%, 18,2 \%, 10,08 \%$ e $9,65 \%$ do total de postos ofertados.

O macro setor Indústria absorveu $13,7 \%$ do total da mão-de-obra do sexo feminino ocupada na economia. A participação da mão-de-obra feminina no total do setor na década de 1990, correspondeu em média a 36,5\% (Quadro 5). As mulheres ocupadas estão concentradas no setor Fabricação de artigos do vestuário e acessórios e no setor Indústria de alimentos em geral. Juntos, estes setores são responsáveis pela ocupação de mais de $60 \%$ da mão-de-obra feminina que atua no macro setor Indústria.

A idade do trabalhador, idade de ingresso no primeiro trabalho, jornada de trabalho e tempo de serviço são bastante homogêneas entre os setores que compõem este macro setor. Todas estas variáveis seguem de perto a média para o total da economia.

Tradicionalmente o setor industrial como um todo tem sido o maior responsável pela oferta de postos de trabalho que asseguram os direitos trabalhistas vinculados a carteira de trabalho. No entanto, este macro setor reduziu a oferta de postos de trabalho com carteira assinada ao longo do período analisado. Em 1992, 58\% da mãode-obra ocupada no macro setor possuía carteira de trabalho. Em 1999, esta participação diminuiu para 55\% aproximadamente.

Os quatro setores onde a participação dos trabalhadores com carteira assinada é maior são, pela ordem, Indústria de alimentos em geral, Siderurgia, metais não ferrosos e outros produtos metalúrgicos, Fabricação de artigos do vestuário e acessórios e Fabricação e manutenção de máquinas e tratores. Nestes setores se concentrava, em média, cerca de $45 \%$ dos trabalhadores com carteira assinada do macro setor.

De outro lado, os setores onde a presença de trabalhadores com carteira assinada é menor são, pela, ordem, Indústria da borracha, Refino de petróleo e indústria petroquímica, Fabricação de produtos farmacêuticos e de perfumaria e indústrias 
diversas, que, somados, concentram aproximadamente $4 \%$ dos trabalhadores com carteira assinada.

A escolaridade deste macro setor é superior a média da economia. A proporção da mão-de-obra ocupada com até 3 anos de estudo é de $13,45 \%$, enquanto que na economia ela é de 27,19\%. A concentração de trabalhadores na classe de 4 a 7 anos, por sua vez, é maior que a média da economia. O mesmo acontece nos extratos superiores.

\begin{tabular}{|c|c|c|c|}
\hline \multicolumn{2}{|l|}{ Gênero } & \multicolumn{2}{|l|}{ Tempo de serviço } \\
\hline - Masculino & 63,55 & - Menos de 1 ano & 22,39 \\
\hline - Feminino & 36,45 & - 1 a 2 anos & 24,63 \\
\hline \multicolumn{2}{|l|}{ Idade } & - 3 a 10 anos & 34,96 \\
\hline - 10 a 14 anos & 2,20 & - $\quad 11$ a 29 anos & 15,11 \\
\hline - 15 a 19 anos & 11,00 & - 30 a 39 anos & 1,97 \\
\hline - 20 a 29 anos & 29,98 & - 40 anos ou mais & 0,94 \\
\hline - 30 a 39 anos & 25,90 & & \\
\hline - 40 a 49 anos & 18,61 & & \\
\hline - 50 anos ou mais & 12,31 & & \\
\hline \multicolumn{2}{|c|}{ Idade de ingresso no primeiro trabalho } & \multicolumn{2}{|c|}{ Jornada de trabalho (horas semanais) } \\
\hline - 10 a 14 anos & 60,76 & - Até 14 horas & 5,21 \\
\hline - 15 a 19 anos & 32,70 & - 15 a 29 horas & 25,39 \\
\hline - 20 a 29 anos & 5,75 & - 30 a 44 horas & 44,20 \\
\hline - 30 a 39 anos & 0,64 & - 45 a 48 horas & 18,51 \\
\hline \multirow[t]{2}{*}{ - 40 anos ou mais } & 0,14 & - 49 horas ou mais & 9,33 \\
\hline & & - Sem declaração & 0,89 \\
\hline \multicolumn{2}{|l|}{ Situação na ocupação } & \multicolumn{2}{|l|}{ Anos de estudo } \\
\hline - Empregado com carteira & 55,88 & - Menos de 1 ano e sem instrução & 5,62 \\
\hline - Empregado sem carteira & 15,49 & - 1 a 3 anos & 7,83 \\
\hline - Funcionário público & 7,37 & - 4 a 7 anos & 35,07 \\
\hline - Conta própria & 16,02 & - 8 a 10 anos & 22,57 \\
\hline - Empregador & 3,22 & - 11 a 14 anos & 21,36 \\
\hline \multirow[t]{2}{*}{ - Não remuner. ou sem declaração } & 2,03 & - 15 anos ou mais & 7,33 \\
\hline & & - Sem declaração & 0,23 \\
\hline
\end{tabular}

Quadro 5 - Perfil da mão-de-obra ocupada no setor Indústria (percentual médio na década). 


\subsubsection{Serviços Industriais de Utilidade Pública}

Este setor tem pequena importância na oferta de postos de trabalho, quando comparado aos demais. Os serviços industriais de utilidade pública responderam, em média, por apenas $0,45 \%$ do total ofertado. A participação da mão-deobra feminina ocupada no setor foi, em média, de 16,45\% (Quadro 6).

A idade predominante dos trabalhadores no setor situa-se na faixa de 20 a 39 anos (cerca de 49\%), não obstante, os trabalhadores com mais de 40 anos também sejam uma parcela significativa (45\%). Logo, a participação da mão-de-obra mais jovem é reduzida $(4,8 \%)$.

A idade de ingresso no primeiro trabalho da mão-de-obra deste setor acompanha o comportamento médio da economia.

A situação na ocupação mostrou que 73,39 \% dos trabalhadores têm carteira assinada, mais o dobro da média nacional. Este setor também apresentou maior participação de trabalhadores na categoria de funcionários públicos que o total da economia, o que pode ser explicado pela natureza da atividade deste setor.

Há também uma menor rotatividade, posto que a proporção de trabalhadores que estavam no setor até 2 anos foi, em média, de 20\%, menor que no conjunto da economia. A concentração de trabalhadores neste setor é maior na faixa entre 11 a 29 anos de tempo de serviço.

A jornada de trabalho parece ser, na média, menor que a do conjunto da economia, prevalecendo a jornada semanal de 30 a 44 horas.

A escolaridade do trabalhador neste setor é superior ao nível médio verificado na economia. Para todos os níveis acima de 11 anos de estudo este setor superou a média nacional, ao mesmo tempo em que os trabalhadores com menos de 3 anos de estudo representaram, na média, uma proporção inferior ao conjunto da economia. 


\begin{tabular}{|c|c|c|c|}
\hline \multicolumn{2}{|l|}{ Gênero } & \multicolumn{2}{|l|}{ Tempo de serviço } \\
\hline - Masculino & 83,55 & - Menos de 1 ano & 10,42 \\
\hline - Feminino & 16,45 & - 1 a 2 anos & 10,17 \\
\hline \multicolumn{2}{|l|}{ Idade } & - 3 a 10 anos & 30,17 \\
\hline - 10 a 14 anos & 0,18 & - 11 a 29 anos & 47,37 \\
\hline - 15 a 19 anos & 4,64 & - 30 a 39 anos & 1,78 \\
\hline - 20 a 29 anos & 17,72 & - 40 anos ou mais & 0,08 \\
\hline - 30 a 39 anos & 31,84 & & \\
\hline - 40 a 49 anos & 33,20 & & \\
\hline - 50 anos ou mais & 12,42 & & \\
\hline \multicolumn{2}{|c|}{ Idade de ingresso no primeiro trabalho } & \multicolumn{2}{|c|}{ Jornada de trabalho (horas semanais) } \\
\hline - 10 a 14 anos & 70,52 & - Até 14 horas & 3,58 \\
\hline - 15 a 19 anos & 26,34 & - 15 a 29 horas & 20,60 \\
\hline - 20 a 29 anos & 3,07 & - 30 a 44 horas & 42,63 \\
\hline - 30 a 39 anos & 0,06 & - 45 a 48 horas & 21,10 \\
\hline \multirow[t]{2}{*}{ - 40 anos ou mais } & 0,01 & - 49 horas ou mais & 12,12 \\
\hline & & - Sem declaração & 0,53 \\
\hline \multicolumn{2}{|l|}{ Situação na ocupação } & \multicolumn{2}{|l|}{ Anos de estudo } \\
\hline - Empregado com carteira & 46,80 & - Menos de 1 ano e sem instrução & 3,97 \\
\hline - Empregado sem carteira & 17,25 & - 1 a 3 anos & 5,02 \\
\hline - Funcionário público & 11,50 & - 4 a 7 anos & 20,94 \\
\hline - Conta própria & 17,88 & - 8 a 10 anos & 20,51 \\
\hline - Empregador & 4,14 & - 11 a 14 anos & 33,71 \\
\hline \multirow[t]{2}{*}{ - Não remuner. ou sem declaração } & 2,43 & - 15 anos ou mais & 15,70 \\
\hline & & - Sem declaração & 0,16 \\
\hline
\end{tabular}

Quadro 6 - Perfil da mão-de-obra ocupada no setor Serviços industriais de utilidade pública (percentual médio na década).

\subsubsection{Construção Civil}

Na década de 1990, a construção civil respondeu, em média, por 6,10\% dos postos de trabalho da economia. Dada a natureza de sua atividade, menos de $4 \%$ da mão-de-obra ocupada é do sexo feminino (Quadro 7).

A idade predominante do trabalhador está na faixa de 20 a 29 anos $(27,07 \%)$, embora a proporção de trabalhadores com idade entre 30 a 39 anos seja quase a mesma $(26,60 \%)$.

A idade de ingresso do trabalhador ocupado no setor acompanhou a média da economia. 
Neste setor, prevalece a mão-de-obra com carteira assinada (46,8\%) que é superior ao observado no conjunto da economia. Nas demais categorias, o setor segue o comportamento geral da atividade.

A jornada de trabalho segue de perto o observado na década de 1990 para o total da economia.

Por conta da atividade deste setor, a rotatividade da mão-de-obra é superior aos demais setores. Cerca de 53\%, em média, dos trabalhadores estava no setor a menos de 2 anos. Este fenômeno é reforçado pela baixa escolaridade presente no setor. Aproximadamente $78 \%$ da mão-de-obra possui menos que 7 anos de estudo. A maior concentração aparece na faixa de 4 a 7 anos de estudo, que engloba $45 \%$ dos trabalhadores.

\begin{tabular}{|c|c|c|c|}
\hline Gênero & & Tempo de serviço & \\
\hline - Masculino & 96,04 & - Menos de 1 ano & 33,11 \\
\hline - Feminino & 3,96 & - $\quad 1$ a 2 anos & 19,96 \\
\hline Idade & & - 3 a 10 anos & 28,40 \\
\hline - 10 a 14 anos & 2,21 & - 11 a 29 anos & 15,96 \\
\hline - 15 a 19 anos & 8,76 & - 30 a 39 anos & 1,90 \\
\hline - 20 a 29 anos & 26,95 & - 40 anos ou mais & 0,67 \\
\hline - 30 a 39 anos & 27,24 & & \\
\hline - 40 a 49 anos & 20,05 & & \\
\hline - 50 anos ou mais & 14,79 & & \\
\hline Idade de ingresso no primeiro trab & & Jornada de trabalho (horas sema & \\
\hline - 10 a 14 anos & 42,71 & - Até 14 horas & 6,29 \\
\hline - 15 a 19 anos & 42,36 & - 15 a 29 horas & 21,67 \\
\hline - 20 a 29 anos & 14,67 & - 30 a 44 horas & 34,24 \\
\hline - 30 a 39 anos & 0,18 & - 45 a 48 horas & 31,20 \\
\hline - 40 anos ou mais & 0,07 & - 49 horas ou mais & 16,71 \\
\hline & & - Sem declaração & 0,72 \\
\hline Situação na ocupação & & Anos de estudo & \\
\hline - Empregado com carteira & 73,39 & - Menos de 1 ano e sem instrução & 15,28 \\
\hline - Empregado sem carteira & 3,68 & - $\quad 1$ a 3 anos & 18,39 \\
\hline - Funcionário público & 21,96 & - 4 a 7 anos & 45,12 \\
\hline - Conta própria & 0,29 & - 8 a 10 anos & 11,77 \\
\hline - Empregador & 0,48 & - 11 a 14 anos & 5,98 \\
\hline - Não remuner. ou sem declaração & 0,19 & - 15 anos ou mais & 3,32 \\
\hline & & - Sem declaração & 0,14 \\
\hline
\end{tabular}

Quadro 7 - Perfil da mão-de-obra ocupada no setor Construção civil (percentual médio na década). 


\subsubsection{Serviços}

O crescente papel das atividades do macro setor Serviços pode ser observado pelo aumento na oferta de postos de trabalho no período. Em 1990 ele era responsável por $51 \%$ do total da oferta de postos de trabalho e em 1999 respondia por quase $58 \%$ do total. Ele foi o segmento da economia que absorveu e gerou a maior quantidade de postos de trabalho em todos os anos da década de 1990.

Não obstante, como os nove setores que o compõem são bastante heterogêneos, alguns não acompanharam o comportamento do todo. Os setores Instituições financeiras, Administração pública e Aluguel de imóveis, fecharam a década com um saldo negativo de 399.000 postos de trabalho a menos.

Os setores que mais expandiram o número de postos de trabalho foram o setor Serviços prestados às famílias, Comércio e Serviços privados não mercantis, os quais, apresentaram, respectivamente, um saldo positivo de 1,98 milhão, 1,7 milhão e 1,47 milhão de postos de trabalho.

O macro setor Serviços respondeu pelo emprego de $74,79 \%$ do total da mão-de-obra do sexo feminino ocupada na atividade econômica. De longe é o macro setor que mais emprega mulheres. Em relação ao total de trabalhadores ocupados no macro setor, 48,71\% são mulheres (Quadro 8). Os setores que empregam mulheres com mais intensidade são, pela ordem, serviços privados não mercantis, Serviços prestados às famílias e Administração pública, responsáveis, em conjunto pela utilização de $82 \%$ da mão-de-obra feminina atuando no macro setor Serviços.

A idade do trabalhador no macro setor Serviços, bem como a idade de ingresso no primeiro emprego e a situação na ocupação estão nos mesmos patamares da média de todos os setores da economia.

Neste macro setor observou-se uma leve tendência de crescimento na participação dos trabalhadores com carteira assinada, a qual está relacionada a evolução dos setor Serviços privados não mercantis. Em 1992, este setor tinha uma proporção de 2,73\% da mão-de-obra ocupada com carteira assinada, alcançando 11,39\% em 1999. Isto 
parece indicar que os trabalhadores domésticos (empregadas domésticas, por exemplo) estão sendo contratados cada vez mais com carteira assinada.

O tempo de serviço dos trabalhadores ocupados no macro setor seguiu a distribuição observada na década de 1990 em toda a economia.

Em geral, as atividades desenvolvidas neste setor parecem permitir uma maior flexibilidade da jornada de trabalho. A maior parte da mão-de-obra ocupada neste macro setor tem uma jornada menor ou igual a 29 horas semanais.

Neste macro setor, a escolaridade da mão-de-obra ocupada foi superior a média da economia na faixa entre 11 a 14 anos de estudo. Enquanto no conjunto da economia ela foi, em média, de $18 \%$, no macro setor ela foi $29 \%$.

\begin{tabular}{|c|c|c|c|}
\hline \multicolumn{2}{|l|}{ Gênero } & \multicolumn{2}{|l|}{\begin{tabular}{|l|} 
Tempo de serviço \\
\end{tabular}} \\
\hline - Masculino & 51,29 & - Menos de 1 ano & 21,34 \\
\hline - Feminino & 48,71 & - $\quad 1$ a 2 anos & 23,42 \\
\hline \multicolumn{2}{|l|}{ Idade } & - 3 a 10 anos & 36,10 \\
\hline - 10 a 14 anos & 2,21 & - 11 a 29 anos & 17,31 \\
\hline - 15 a 19 anos & 8,76 & - 30 a 39 anos & 1,41 \\
\hline - 20 a 29 anos & 26,95 & - 40 anos ou mais & 0,42 \\
\hline - 30 a 39 anos & 27,24 & & \\
\hline - 40 a 49 anos & 20,05 & & \\
\hline - 50 anos ou mais & 14,79 & & \\
\hline \multicolumn{2}{|c|}{ Idade de ingresso no primeiro trabalho } & \multicolumn{2}{|c|}{ Jornada de trabalho (horas semanais) } \\
\hline - 10 a 14 anos & 51,69 & - Até 14 horas & 10,82 \\
\hline - 15 a 19 anos & 35,87 & - 15 a 29 horas & 29,56 \\
\hline - 20 a 29 anos & 11,22 & - 30 a 44 horas & 29,82 \\
\hline - 30 a 39 anos & 0,90 & - 45 a 48 horas & 17,15 \\
\hline \multirow[t]{2}{*}{ - 40 anos ou mais } & 0,32 & - 49 horas ou mais & 13,25 \\
\hline & & - Sem declaração & 1,45 \\
\hline \multicolumn{2}{|l|}{ Situação na ocupação } & \multicolumn{2}{|l|}{ Anos de estudo } \\
\hline - Empregado com carteira & 36,45 & - Menos de 1 ano e sem instrução & 7,29 \\
\hline - Empregado sem carteira & 25,18 & - $\quad 1$ a 3 anos & 7,13 \\
\hline - Funcionário público & 15,87 & - 4 a 7 anos & 22,88 \\
\hline - Conta própria & 19,04 & - 8 a 10 anos & 17,69 \\
\hline - Empregador & 2,44 & - 11 a 14 anos & 29,41 \\
\hline \multirow[t]{2}{*}{ - Não remuner. ou sem declaração } & 1,03 & - 15 anos ou mais & 15,46 \\
\hline & & - Sem declaração & 0,14 \\
\hline
\end{tabular}

Quadro 8 - Perfil da mão-de-obra ocupada no setor Serviços (percentual médio na década). 


\section{5 Índice de qualificação relativa da mão-de-obra ocupada}

Conforme já indicado na seção 4.6, o índice de qualificação relativa mostra a intensidade na utilização de trabalhadores com um dado nível de qualificação em relação a proporção utilizada destes trabalhadores no conjunto da economia. Portanto, quando o índice for maior que a unidade, significa que o setor em questão, no ano analisado, emprega proporcionalmente mais pessoas que o conjunto da economia para um dado nível de qualificação.

Os resultados mostraram que a mão-de-obra com baixa qualificação ${ }^{6}$ é utilizada principalmente nos setores Agropecuária, Extração mineral (exceto combustíveis), Fabricação de minerais não metálicos, Serrarias e fabricação de artigos de madeira e mobiliário, Fabricação de calçados e de artigos de couro, Construção civil, Transporte e Serviços privados não mercantis. Dentre estes setores, a maior proporção da mão-de-obra com baixa escolaridade encontra-se no setor Agropecuária, Serviços privados não mercantis e Construção civil (Tabela 6).

A mão-de-obra com média qualificação ${ }^{7}$ é utilizada com mais intensidade nos setores Siderurgia, metais não ferrosos e outros produtos metalúrgicos, Indústria da borracha e Indústrias diversas.

Os setores que absorveram mão-de-obra com maior qualificação ${ }^{8}$ estão situados basicamente no macro setor Serviços. Dentre os setores que o compõem, destaca-se o comportamento apresentado principalmente pelos setores Instituições financeiras, Serviços prestados às empresas e Administração Pública que, durante a década de 1990, aumentaram a intensidade da utilização de mão-de-obra com média e alta qualificação.

\footnotetext{
${ }^{6}$ Para efeitos de análise, considera-se como tal a mão-de-obra com, no máximo, 7 anos de estudo.

${ }^{7}$ Entendida como aquela que possui de 8 a 14 anos de estudo.

${ }^{8}$ Mão-de-obra com mais de 15 anos de estudo.
} 
Tabela 6. Índice de qualificação relativa.

\begin{tabular}{|c|c|c|c|c|c|c|c|c|c|c|c|c|c|c|c|c|c|c|c|c|c|c|}
\hline & & & 1992 & & & 1993 & & & 1995 & & & 1996 & & & 1997 & & & 1998 & & & 1999 & \\
\hline & & $I B Q R$ & $I M Q R$ & $I A Q R$ & $I B Q R$ & $I M Q R$ & $I A Q R$ & $I B Q R$ & $I M Q R$ & $I A Q R$ & $I B Q R$ & $I M Q R$ & $I A Q R$ & $I B Q R$ & $I M Q R$ & $I A Q R$ & $I B Q R$ & $I M Q R$ & $I A Q R$ & $I B Q R$ & $I M Q R$ & $I A Q R$ \\
\hline 1 & ecuária & 1,376 & 0,331 & 0,431 & 1,462 & 0,405 & 0,628 & 1,795 & 0,187 & 0,348 & 1,463 & 0,281 & 0,409 & 1,500 & 0,247 & 0,398 & 1,538 & 0,241 & 0,352 & 1,573 & 0,234 & 0,261 \\
\hline 3 & $\begin{array}{l}\text { Extrativa mineral (exceto } \\
\text { combustivieis) } \\
\text { Ext. petróleo, gás natural, carvão e }\end{array}$ & 1,433 & 0,266 & 0,200 & 1,605 & 0,344 & 0,147 & 0,979 & 1,236 & 0,654 & 1,548 & 0,207 & 0,079 & 1,465 & 0,376 & 0,141 & 1,494 & 0,400 & 0,019 & 1,440 & 0,449 & 0,279 \\
\hline & outros comb. & 0,461 & 1,794 & 2,473 & 0,364 & 1,680 & 1,925 & 0,259 & 1,335 & 2,321 & 0,364 & 1,571 & 3,404 & 0,301 & 2,007 & 2,022 & 0,425 & 1,468 & 3,062 & 0,298 & 1,578 & 3,406 \\
\hline 5 & $\begin{array}{l}\text { Fabricação } \mathrm{c} \\
\text { Siderurgia, } \mathrm{n}\end{array}$ & 1,244 & 0,655 & 0,278 & 1,295 & 0,752 & 0,367 & 1,252 & 0,857 & 0,599 & 1,278 & 0,690 & 0,182 & 1,267 & 0,689 & 0,317 & 1,222 & 0,789 & 0,326 & 1,205 & 0,832 & 0,299 \\
\hline 6 & $\begin{array}{l}\text { prod. met. } \\
\text { Fabricação e manutenção de máquinas }\end{array}$ & 0,898 & 1,311 & 0,638 & 0,859 & 1,373 & 0,542 & 0,701 & 1,435 & 1,028 & 0,839 & 1,419 & 0,553 & 0,904 & 1,268 & 0,629 & 0,859 & 1,320 & 0,692 & 0,789 & 1,458 & 0,534 \\
\hline 7 & $\begin{array}{l}\text { e tratores } \\
\text { Fab. de aparelhos e equ }\end{array}$ & 0,800 & 1,448 & 0,935 & 0,862 & 1,260 & 0,865 & 0,411 & 1,752 & 1,231 & 0,757 & 1,510 & 0,795 & 0,691 & 1,520 & 1,151 & 0,690 & 1,552 & 0,922 & 0,693 & 1,476 & 1,123 \\
\hline 8 & $\begin{array}{l}\text { eletrônicos } \\
\text { Fab de auton }\end{array}$ & 0,555 & 1,898 & 1,241 & 0,513 & 1,748 & 1,035 & 0,570 & 1,821 & 0,709 & 0,542 & 1,869 & 0,975 & 0,513 & 1,861 & 0,081 & 0,509 & 1,784 & 1,230 & 0,424 & 1,854 & 1,387 \\
\hline 9 & artigos de madeira e & 0,708 & 1,582 & 1,196 & 0,759 & 1,437 & 0,816 & 0,472 & 1,932 & 0,772 & 0,694 & 1,656 & 0,690 & 0,657 & 1,615 & 1,025 & 0,598 & 1,640 & 1,201 & 0,556 & 1,688 & 1,174 \\
\hline 10 & $\begin{array}{l}\text { mobiliário } \\
\text { Indústria de papel e gráfica }\end{array}$ & $\begin{array}{l}1,199 \\
0,662\end{array}$ & $\begin{array}{l}0,784 \\
\mathbf{1 , 6 6 3}\end{array}$ & $\begin{array}{l}0,153 \\
\mathbf{1 , 2 6 7}\end{array}$ & $\begin{array}{l}\mathbf{1 , 2 5 5} \\
0,564\end{array}$ & $\begin{array}{l}0,887 \\
\mathbf{1 , 6 5 7}\end{array}$ & $\begin{array}{l}0,153 \\
\mathbf{1 , 0 6 8}\end{array}$ & $\begin{array}{l}1,345 \\
0,291\end{array}$ & $\begin{array}{l}0,999 \\
\mathbf{1 , 7 7 6}\end{array}$ & $\begin{array}{l}0,124 \\
\mathbf{1 , 4 9 6}\end{array}$ & $\begin{array}{l}1,257 \\
0,606\end{array}$ & $\begin{array}{l}0,748 \\
\mathbf{1 , 6 9 6}\end{array}$ & $\begin{array}{l}0,112 \\
\mathbf{1 , 1 7 6}\end{array}$ & $\begin{array}{l}1,235 \\
0,624\end{array}$ & $\begin{array}{l}0,796 \\
\mathbf{1 , 6 4 8}\end{array}$ & $\begin{array}{l}0,126 \\
\mathbf{1 , 1 3 2}\end{array}$ & $\begin{array}{l}\mathbf{1 , 2 2 6} \\
0,591\end{array}$ & $\begin{array}{l}0,836 \\
\mathbf{1 , 6 8 2}\end{array}$ & $\begin{array}{l}0,116 \\
\mathbf{1 , 0 7 7}\end{array}$ & $\begin{array}{l}\mathbf{1 , 2 3 0} \\
0,500\end{array}$ & $\begin{array}{l}0,813 \\
\mathbf{1 , 8 1 6}\end{array}$ & $\begin{array}{l}0,201 \\
\mathbf{1 , 0 2 7}\end{array}$ \\
\hline $\begin{array}{l}11 \\
12\end{array}$ & $\begin{array}{l}\text { Indústria da } \\
\text { Fab. Elem. }\end{array}$ & 0,902 & 1,376 & 0,341 & 0,799 & 1,589 & 0,175 & 0,547 & 1,929 & 0,585 & 0,846 & 1,423 & 0,488 & 0,920 & 1,317 & 0,325 & 0,722 & 1,628 & 0,396 & 0,816 & 1,497 & 0,182 \\
\hline 13 & $\begin{array}{l}\text { quím. c } \\
\text { Refino }\end{array}$ & 0,909 & 1,115 & 1,327 & 0,776 & 1,285 & 1,193 & 0,748 & 1,039 & 1,575 & 0,861 & 1,215 & 1,179 & 0,842 & 1,211 & 1,296 & 0,855 & 1,082 & 1,660 & 0,809 & 1,231 & 1,344 \\
\hline 14 & $\begin{array}{l}\text { petroquímica } \\
\text { Fab. de produtos farmacêuticos e de }\end{array}$ & 0,550 & 1,649 & 2,292 & 0,430 & 1,629 & 1,771 & 0,383 & 0,441 & 3,516 & 0,473 & 1,700 & 2,124 & 0,519 & 1,557 & 2,234 & 0,470 & 1,437 & 2,877 & 0,431 & 1,564 & 2,554 \\
\hline 15 & $\begin{array}{l}\text { perfumaria } \\
\text { Indústria de transformação de material }\end{array}$ & 0,586 & 1,940 & 0,818 & 0,576 & 1,560 & 1,298 & 0,535 & 1,213 & 1,826 & 0,569 & 1,647 & 1,633 & 0,475 & 1,756 & 1,766 & 0,484 & 1,691 & 1,768 & 0,386 & 1,846 & 1,689 \\
\hline & plástico & 0,881 & 1,313 & 0,779 & 0,915 & 1,341 & 0,377 & 0,695 & 1,827 & 0,381 & 0,861 & 1,386 & 0,519 & 0,855 & 1,363 & 0,603 & 0,781 & 1,424 & 0,807 & 0,742 & 1,538 & 0,525 \\
\hline $\begin{array}{l}16 \\
17\end{array}$ & $\begin{array}{l}\text { Indústria T } \\
\text { Fabricaçãa }\end{array}$ & 1,057 & 1,042 & 0,340 & 1,050 & 1,147 & 0,330 & 1,128 & 1,067 & 0,560 & 1,002 & 1,157 & 0,384 & 1,032 & 1,079 & 0,458 & 0,950 & 1,225 & 0,445 & 0,990 & 1,172 & 0,348 \\
\hline 18 & $\begin{array}{l}\text { acessó } \\
\text { Fab. d }\end{array}$ & 1,094 & 1,016 & 0,128 & 1,092 & 1,113 & 0,234 & 1,136 & 1,209 & 0,300 & 1,070 & 1,074 & 0,211 & 1,065 & 1,087 & 0,193 & 1,068 & 1,084 & 0,200 & 1,081 & 1,052 & 0,226 \\
\hline & e pele & 1,251 & 0,683 & 0,108 & 1,188 & 0,970 & 0,215 & 0,818 & 1,484 & 0,646 & 1,198 & 0,823 & 0,243 & 1,177 & 0,893 & 0,161 & 1,077 & 1,063 & 0,224 & 1,142 & 0,961 & 0,186 \\
\hline 19 & Indústria de alimentos em geral & 1,041 & 1,071 & 0,362 & 1,014 & 1,188 & 373 & 0,886 & 1,432 & 0,559 & 1,041 & 1,064 & 0,456 & 1,042 & 1,071 & 0,422 & 1,040 & 1,092 & 0,363 & 0,988 & 1,147 & 0,467 \\
\hline $\begin{array}{l}20 \\
21\end{array}$ & $\begin{array}{l}\text { Indústrii } \\
\text { Serviços }\end{array}$ & 0,856 & 1,456 & 0,419 & 0,794 & 1,503 & 0,455 & 0,565 & 1,818 & 0,726 & 0,825 & $1, \mathbf{4 4 2}$ & 0,564 & 0,765 & 1,452 & 0,900 & 0,887 & 1,279 & 0,660 & 0,867 & 1,358 & 0,417 \\
\hline & públic & 0,546 & 1,775 & 1,814 & 0,501 & 1,601 & 1,524 & 0,378 & 1,435 & 1,850 & 0,554 & 1,634 & 1,790 & 0,569 & 1,543 & 1,938 & 0,524 & 1,644 & 1,688 & 0,499 & 1,655 & 1,704 \\
\hline 22 & Construção civil & 1,278 & 588 & 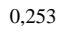 & 1,391 & 0,615 & 0,331 & 1,398 & 0,581 & 0,6 & 1,380 & 0,490 & 0,20 & 1,390 & 0,490 & 0,229 & 1,403 & 0,501 & 0,239 & 1,395 & 0,533 & 0,238 \\
\hline 23 & omérc & 0,5 & ,804 & 1,4 & 0,4 & 1,710 & 1,4 & 0,2 & 1,726 & 1,6 & 0,524 & 1,741 & 1,5 & 0,472 & 1,847 & 1,429 & 0,493 & 1,745 & 1 , & 0,496 & 1,737 & 1,388 \\
\hline 24 & Transpo & 1,353 & 0,454 & 0,1 & 1,358 & 0,655 & 0, & 1,414 & 0,841 & 0,213 & 1,343 & 0,520 & 0,363 & 1,369 & 0,518 & 0,266 & 1,391 & 0,529 & 0,208 & 1,439 & 0,444 & 0,311 \\
\hline 25 & Comunicaçõe & 0,298 & 2,271 & 1,974 & 0,211 & 2,002 & 1,679 & 0,209 & 2,210 & 0,973 & 0,323 & 2,146 & 1,495 & 0,294 & 2,087 & 1,758 & 0,276 & 2,039 & 1,809 & 0,249 & 2,059 & 1,735 \\
\hline 26 & Instituições Fin &, 12 & 368 & 3,071 & 0,113 & 1,892 & 2,4 & 0, & 1,745 & 1,9 & 0,124 & 1,938 & 3 , & 0,092 & 1,973 & 3,644 & 0,122 & 1,871 & 9 & 0,102 & 1,782 & 3,904 \\
\hline 27 & Servi & 0,8 & 1,278 & & & 1,302 & & 0 , & 1,548 & 1, & & 1,301 & 1, & 0,838 & 1,263 & 17 & 0,828 & 1,265 & 18 & 0,791 & 1,293 & 1,207 \\
\hline 28 & Servi & 0,617 & 1,480 & 2,38 & 0,519 & 1,291 & 2,36 & 0 & 1,005 & 2,898 & 0,522 & 1,431 & 2,804 & 0,533 & 1,360 & 2,909 & 0,481 & 1,369 & 3,065 & 0,450 & 1,403 & 3,093 \\
\hline 29 & Aluguel de imóveis & 0,160 & 0,708 & 9,40 & 0,4 & 1,729 & 1,4 & 0,538 & 1,305 & 1,661 & 0,484 & 1,786 & 1,712 & 0,379 & 1,815 & 2,217 & 0,356 & 1,724 & 2,512 & 0,351 & 1,764 & 2,266 \\
\hline 30 & & 0,516 & & & & & & 0,324 & 1 , & 2, & 0 & 1,572 & & 0 & 1,551 & 2,842 & 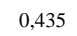 & 1,552 & 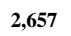 & 2 & 15 & 2,887 \\
\hline 31 & Serviços pri & 1,343 & 0.475 & 0,135 & 1.487 & 0.529 & 0,144 & 1,648 & 0.544 & 0,118 & 1,411 & 0.473 & 0,049 & 1.419 & 0.483 & 0.048 & 1.407 & 0,543 & 0,042 & 1,374 & 0.612 & 0,054 \\
\hline
\end{tabular}

Fonte: Dados da pesquisa. 


\section{Conclusões}

No que se refere à geração de postos de trabalho, a literatura corrente aponta uma dificuldade das cadeias produtivas em manter o potencial de oferta de postos de trabalho. Ressalta-se também que o processo de abertura, ao expor as indústrias a um ambiente mais competitivo fez com elas reestruturassem seu processo produtivo, buscando aumentar a produtividade. O reflexo disto, foi uma diminuição dos postos de trabalho, que segundo alguns autores, foram parcialmente compensados pelo aumento da mão-de-obra ocupada no setor Serviços.

A análise dos dados mostrou que o balanço na oferta de postos de trabalho foi positivo na década de 1990, tendo sido gerados aproximadamente 3,8 milhões de postos de trabalho, o que representou um crescimento médio anual de aproximadamente $0,71 \%$.

A partir da compatibilização dos dados das PNADs e das matrizes de insumo-produto, obtidas das Contas Nacionais, foi possível evidenciar as mudanças setoriais na oferta de postos de trabalho e o perfil dos trabalhadores ocupados na economia ao longo da década de 1990. Esta abordagem também possibilitou identificar a importância dos componentes da demanda total na geração de postos de trabalho nos vários setores da economia.

A análise do perfil da mão-de-obra ocupada no Brasil na década de 1990

mostrou que somente algo em torno de $1 / 3$ dos postos de trabalho foram ocupados pela mão-de-obra feminina, a qual estava concentrada no setor Serviços.

Para o conjunto da economia, a idade do trabalhador ocupado concentrou-se na faixa dos 20 a 39 anos, tendo diminuído a participação da mão-de-obra jovem e aumentado, ainda que timidamente, a ocupação de trabalhadores com idade superior a 50 anos.

O setor Agropecuária foi o que mais empregou mão-de-obra na faixa dos 10 a 14 anos. Em contrapartida, no setor Extração de petróleo, gás natural, carvão e 
outros combustíveis os postos de trabalho ocupados nesta categoria são desprezíveis. Este setor é o que ocupa com mais intensidade a mão-de-obra madura (acima dos 40 anos).

A maioria da mão-de-obra ocupada na década começou a trabalhar com 10 a 14 anos, porém os trabalhadores que estão ingressando no primeiro emprego, o fazem mais tarde. A análise da situação na ocupação dos trabalhadores mostrou que, notadamente a partir da segunda metade da década, o número de trabalhadores sem carteira assinada aumentou a uma taxa de mais de $24 \%$ ao ano, indicando uma possível piora nas relações de trabalho. Em 1995, os trabalhadores sem carteira assinada eram cerca de 8,36 milhões de pessoas e em 1999 eram 19,80 milhões de pessoas. Constatouse ainda uma redução abrupta no número de pessoas trabalhando por conta própria e um aumento no número de postos de trabalho na administração pública.

Não obstante, os trabalhadores ocupados no setor Extração de petróleo, gás natural, carvão e outros combustíveis e no setor Serviços industriais e de utilidade pública eram, em sua grande maioria, contratados com carteira de trabalho assinada.

O tempo de serviço da mão-de-obra ocupada na década de 1990 parece também indicar a precarização das relações de trabalho. Ao longo da década, algo em torno de $40 \%$ das pessoas estavam no atual emprego entre menos de 1 ano a 2 anos. A rotatividade é maior no setor Construção civil, onde, em média, 53\% dos trabalhadores estavam no atual emprego a menos de 2 anos.

Na década de 1990, o número de horas de trabalho semanais era maior que 45 horas para cerca de $40 \%$ da mão-de-obra ocupada, embora mais de $20 \%$, em média, dos trabalhadores ocupados trabalhava em tempo parcial. No setor Serviços esta jornada de trabalho era mais comum.

Em que pese ter-se observado, a partir da segunda metade da década de 1990, um ligeiro crescimento para a escolaridade da mão-de-obra ocupada entre 8 a 14 anos, a maioria dos trabalhadores ocupados durante todo período analisado possui de 4 a 7 anos de estudo. Não obstante, a construção de um índice de qualificação relativa 
permitiu verificar a intensidade do emprego de trabalhadores nos vários níveis de qualificação.

Por outro lado, a utilização das matrizes de insumo-produto permitiu analisar a importância de cada um dos componentes da demanda final na geração de postos de trabalho. Os resultados mostraram que, na década de 1990, o consumo intermediário foi responsável, em média, por mais da metade da oferta de postos de trabalho. Dos trinta e um setores analisados, dezoito dependem mais fortemente do consumo intermediário. A demanda final foi significativa em onze setores e apenas um [Extrativa mineral (exceto combustíveis)] a exportação teve a maior participação na oferta de postos de trabalho. 
ANEXO A - Compatibilização dos setores da PNAD.

\begin{tabular}{|c|c|c|}
\hline & Setores da matriz & Setores da PNAD \\
\hline 01 & Agropecuária & $\begin{array}{c}11,12,13,14,15,16,17,18,19,20 \\
21,22,23,24,25,26,27,28,29,31 \\
32,33,34,35,36,37,41,42 \text { e } 581\end{array}$ \\
\hline 02 & Extrativa mineral (exceto combustíveis) & $50,53,54,55,56,57,58,59$ \\
\hline 03 & Extração de petróleo,gás natural, carvão outros combustíveis & 51 e 52 \\
\hline 04 & Fabricação de minerais não metálicos & 100 \\
\hline 05 & Siderurgia, metais não ferrosos e out. produtos metalúrgicos & 110 \\
\hline 06 & Fabricação e manutenção de máquinas e tratores & 120 \\
\hline 07 & Fabricação aparelhos equipamento.material elétrico e eletrônico & 130 \\
\hline 08 & Fabricação automóveis caminhões ônibus, peças e acessórios & 140 \\
\hline 09 & Serrarias e fabricação de artigos de madeira e mobiliário & 150,151 e 160 \\
\hline 10 & Indústria de papel e gráfica & 170 e 290 \\
\hline 11 & Indústria da borracha & 180 \\
\hline 12 & Fab. elementos químicos não petroquímicos e químicos diversos & 200 \\
\hline 13 & Refino de petróleo e indústria petroquímica & 201,202 e 352 \\
\hline 14 & Fabricação de produtos farmacêuticos e de perfumaria & 210 e 220 \\
\hline 15 & Indústria de transformação de material plástico & 230 \\
\hline 16 & Indústria Têxtil & 240 e 241 \\
\hline 17 & Fabricação de artigos do vestuário e acessórios & 250 e 532 \\
\hline 18 & Fabricação de calçados e de artigos de couro e peles & 190 e 151 \\
\hline 19 & Indústria de alimentos & $260,261,270$ e 280 \\
\hline 20 & Indústrias diversas & 300 \\
\hline 21 & Serviços industriais utilidade pública - SIUP & 351 e 353 \\
\hline 22 & Construção civil & 340 \\
\hline 23 & Comércio & $\begin{array}{c}410,411,412,413,414,415,416,417 \\
418,419,420,421,422,423,424,582 \mathrm{e} \\
583\end{array}$ \\
\hline 24 & Transporte & $471,472,473,474,475,476,477$ e 588 \\
\hline 25 & Comunicações & 481,482 \\
\hline 26 & Instituições Financeiras & $451,452,453,585$ e 612 \\
\hline 27 & Serviços prestados às famílias & $\begin{array}{l}463,511,512,521,522,523,524,525, \\
531,533,541,542,545,551,577,586, \\
587,622,623,624,632,801,901 \text { e } 902\end{array}$ \\
\hline 28 & Serviços prestados às empresas & $\begin{array}{c}462,464,543,552,571,572,573,574 \\
575,576,578,584,585,586,578,588, \\
589\end{array}$ \\
\hline 29 & Aluguel de imóveis & 461 \\
\hline 30 & Administração Pública & $\begin{array}{c}354,610,611,621,631,711,712,713 \\
714,715,716,717,721,722,723,724 \\
725,726,727\end{array}$ \\
\hline 31 & Serviços privados não mercantis & $544,613,614,615,616,617,618,619$ \\
\hline
\end{tabular}


ANEXO B - Ramos e classes de atividades contidos na PNAD.

\begin{tabular}{|c|c|}
\hline 11- Cultura de agave & 160- Indústria mobiliário \\
\hline 12- Cultura de algodão & 170- Ind. papel e papelão \\
\hline 13- Cultura de arroz & 180- Indústria borracha \\
\hline 14- Cultura de banana & 190- Ind. de couros e pele \\
\hline 15- Cultura de cacau & 200- Indústria química \\
\hline 16- Cultura de café & 201-Ind. produtos petróleo \\
\hline 17- Cultura. de cana-de-açúcar & 210- Ind. farm. veterinária \\
\hline 18- Cultura de fumo & 220- Ind. perf. sabão vela \\
\hline 19- Cultura de mandioca & 230- Ind. produtos plástico \\
\hline 20- Cultura de milho & 240- Indústria têxtil \\
\hline 21- Cultura de soja & 241- Ind. domiciliar têxtil \\
\hline 22- Cultura de trigo & 250- Indústria do vestuário \\
\hline 23- Horticultura. / floricultura & 251- Indústria de calçados \\
\hline 24- Silvicultura & 260- Ind. prod. alimentar \\
\hline 25- Cultura. não discriminada & 270- Indústria de bebidas \\
\hline 26- Pecuária & 280- Indústria de fumo \\
\hline 27- Avicultura & 290- Ind. editora e gráfica \\
\hline 28- Apicultura. / sericultura & 300- Atividade não definida \\
\hline 29- Atividade.não especificada & 340- Indústria da construção \\
\hline 31- Extração de borracha & 351- Prod.dist.energia elét. \\
\hline 32- Extração de erva-mate & 352- Prod.dist. gás canaliz. \\
\hline 33- Extração de. plantas fibrosas & 353- Abastecimento água etc \\
\hline 34- Extração. frutos sementes & 354- Limpeza púb. rem. lixo \\
\hline 35- Extração de madeiras & 410- Com. de prod. agrop.ex. \\
\hline 36- Prod. carvão vegetal & 411- Com. gênero alimentício \\
\hline 37- Atividade não definida & 412- Com. tecido art. tecido \\
\hline 41- Pesca & 413- Com. móveis tapeç.artes \\
\hline 42- Piscicultura & 414- Com. papel impresso \\
\hline 50- Aparelho ext.mat.const & 415-Com. de ferragens etc \\
\hline 51- Extr.petróleo gás nat. & 416- Com. máq. aparelho ind. \\
\hline 52- Extr. carvão de pedra & 417- Com. veículos acessório \\
\hline 53- Expl. salinas / fontes & 418-Com.prod.quím/farmaceu \\
\hline 54- Faísc.gar.min.n metal. & 419- Com. combust. Lubrific. \\
\hline 55- Faísc.gar.min. metál. & 420- Comércio ambulante \\
\hline 56- Extr. min. radioativos & 421- Feiras \\
\hline 57- Extr. min não metal & 422- Supermercados \\
\hline 58- Extr.min. metálicos & 423- Loja de departamento \\
\hline 59- Atividade não definida & 424- Atividade não definida \\
\hline 100- Ind. transf.min.n met. & 451- Bancos financeiras etc \\
\hline 110- Indústria metalúrgicas & 452- Caixas econôm. cooper. \\
\hline 120- Indústrias mecânicas & 453-Seguros \\
\hline 130- Ind. mat. elétrico com & 461- Adm.com.incorp.imóveis \\
\hline 140- Ind. mat. p/transporte & 462- Com. títulos e moedas \\
\hline 150- Indústria madeira & $\begin{array}{l}\text { 463- Conces. loterias etc } \\
\text { 464- Org. cartão crédito }\end{array}$ \\
\hline
\end{tabular}


ANEXO B - Ramos e classes de atividades contidos na PNAD.

\begin{tabular}{|c|c|}
\hline 471- Trans. tração animal & 612- Previd. Soc. particular \\
\hline 472- Trans. rodov. passag. & 613- Sind. associação classe \\
\hline 473- Trans. rodov. carga & 614- Inst.cient. tecnológica \\
\hline 474- Transporte ferroviário & 615-Inst. filos. cultural \\
\hline 475- Transporte marítimo & 616- Culto ativi.auxiliares \\
\hline 476- Transporte aéreo & 617- Ent. desp. recreativa \\
\hline 477- Atividade não definida & 618- Org. civil política \\
\hline 481- Serviços postais & 619- Serv.comunitário social \\
\hline 482- Comunic. telefônicas & 621- Serv. médicos públicos \\
\hline 511- Serviço de alojamento & 622- Serv. médico particular \\
\hline 512- Serviço de alimentação & 623- Serviços odontológicos \\
\hline 521- Serv. repar. elétrica & 624- Serviços veterinários \\
\hline 522- Serv. repar. veículos & 631- Ens. públ. fed.est.mun. \\
\hline 523- Serv.reparação madeira & 632- Ensino particular \\
\hline 524- Serv. repar. instalação & 711- Poder legislativo \\
\hline 525- Serv. repar. $\mathrm{n}$ incluso & 712- Justiça ativi. auxiliar \\
\hline 531- Serv. higiene pessoal & 713- Ser. administ. federal \\
\hline 532- Serviço de confecção & 714- Ser. administ. estadual \\
\hline 533- Serv.pessoal $\mathrm{n}$ incluso & 715- Ser.administ. municipal \\
\hline 541- Serv.conser. vestuário & 716- Ser. adm. autarquia \\
\hline 542- Serv. limp.conservação & 717- Ser. adm. não definida \\
\hline 543- Serv. vigilante guarda & 721- Exército \\
\hline 544- Serv.domést. remunerado & 722- Marinha de guerra \\
\hline 545- Serv. dom. não incluso & 723- Aeronáutica \\
\hline 551- Serv. div. artístico & 724- Polícia militar \\
\hline 552- Serviço rádiodifusão & 725- Polícia civil \\
\hline 571- Serviço jurídico & 726- Corpo de bombeiros \\
\hline 572- Serv.contábil auditoria & 727- Outra org. gov. seg. \\
\hline 573- Serviço assessoria & 801- Org.int.repr. estrang. \\
\hline 574- Serv. eng. arquitetura & 901- Outra ativ.n definida \\
\hline 575- Serv.public. propaganda & 902- Atividade mal definida \\
\hline \multicolumn{2}{|l|}{ 576- Serviço tradução } \\
\hline \multicolumn{2}{|l|}{ 577- Serv. pintura-atelier } \\
\hline \multicolumn{2}{|l|}{ 578-Serv. téc.-profissional } \\
\hline \multicolumn{2}{|l|}{ 581- Serv. aux. agrop. pec. } \\
\hline \multicolumn{2}{|l|}{ 582- Ser. aux. com. mercad. } \\
\hline \multicolumn{2}{|l|}{ 583- Serviço de armazenagem } \\
\hline \multicolumn{2}{|l|}{ 584- Ser.aux. com/indústria } \\
\hline \multicolumn{2}{|l|}{ 585- Serviço aux. seguros } \\
\hline \multicolumn{2}{|l|}{ 586- Serviços. transp. $\mathrm{n}$ rodov. } \\
\hline \multicolumn{2}{|l|}{ 587- Serviços.aux.transp. rodov. } \\
\hline \multicolumn{2}{|l|}{ 588- Ser.aux.transp. marít. } \\
\hline \multicolumn{2}{|l|}{ 589- Ser. aux. todas ativi. } \\
\hline \multicolumn{2}{|l|}{ 610-Assistência beneficente } \\
\hline 611- Previd. social pública & \\
\hline
\end{tabular}


ANEXO C - Compatibilização dos setores.

\begin{tabular}{|c|c|c|c|c|c|}
\hline & Descrição & Agregação & Setor & Descrição & Macro setor \\
\hline 01 & Agropecuária & 01 & 01 & Agropecuária & 01 \\
\hline 02 & Extrativa mineral & 02 & 02 & Extrativa mineral (exceto combustíveis) & 02 \\
\hline 03 & Extração de petróleo e gás & 03 & 03 & Extração de petróleo, gás natural, carvão e outros combustíveis & 03 \\
\hline 04 & Minerais não-metálicos & 04 & 04 & Fabricação de minerais não metálicos & 04 \\
\hline 05 & Siderurgia & $(5+6+7)$ & 05 & Siderurgia, metais não ferrosos e outros produtos metalúrgicos & 04 \\
\hline 06 & Metalurgia e metais não-ferrosos & 08 & 06 & Fabricação e manutenção de máquinas e tratores & 04 \\
\hline 07 & Outros metalúrgicos & $(9+10)$ & 07 & Fabricação de aparelhos e equipamentos elétricos e eletrônicos & 04 \\
\hline 08 & Máquinas e tratores & $(11+12)$ & 08 & Fabricação de automóveis caminhões, ônibus, peças e acessórios & 04 \\
\hline 09 & Material elétrico & 13 & 09 & Serrarias e fabricação de artigos de madeira e mobiliário & 04 \\
\hline 10 & Equipamentos eletrônicos & 14 & 10 & Indústria de papel e gráfica & 04 \\
\hline 12 & Outros veículos e peças & $(16+18)$ & 12 & Fabricação elementos químicos não petroquímicos e químicos diversos & 04 \\
\hline 13 & Madeira e mobiliário & 19 & 13 & Refino de petróleo e indústria petroquímica & 04 \\
\hline 14 & Papel e gráfica & 20 & 14 & Fabricação de produtos farmacêuticos e de perfumaria & 04 \\
\hline 15 & Indústria da borracha & 21 & 15 & Indústria de transformação de material plástico & 04 \\
\hline 16 & Elementos químicos & 22 & 16 & Indústria Têxtil & 04 \\
\hline 17 & Refino do petróleo & 23 & 17 & Fabricação de artigos do vestuário e acessórios & 04 \\
\hline 18 & Químicos diversos & $(24$ a 30$)$ & 18 & Fabricação de calçados e de artigos de couro e peles & 04 \\
\hline 19 & Farmacêutica e de perfumaria & 31 & 19 & Indústria de alimentos em geral & 04 \\
\hline 20 & Artigos de plástico & 32 & 20 & Indústrias diversas & 04 \\
\hline 21 & Indústria têxtil & 33 & 21 & Serviços industriais de utilidade pública & 05 \\
\hline 23 & Fabricação de calçados & 35 & 23 & Comércio & 07 \\
\hline 24 & Indústria do café & 36 & 24 & Transporte & 07 \\
\hline 25 & Beneficiamento de produtos vegetais & 37 & 25 & Comunicações & 07 \\
\hline 26 & Abate de animais & 38 & 26 & Instituições Financeiras & 07 \\
\hline 27 & Indústria de laticínios & 39 & 27 & Serviços prestados às famílias & 07 \\
\hline 28 & Indústria de açúcar & 40 & 28 & Serviços prestados às empresas & 07 \\
\hline 29 & Fabricação de óleos vegetais & 41 & 29 & Aluguel de imóveis & 07 \\
\hline 30 & Outros produtos alimentares & 42 & 30 & Administração Pública & 07 \\
\hline 31 & Indústrias diversas & & 31 & Serviços privados não mercantis & 07 \\
\hline 32 & Serviços industriais de utilidade pública & & & & \\
\hline 33 & Construção civil & & & & \\
\hline 34 & Comércio & & & & \\
\hline 35 & Transportes & & & & \\
\hline 36 & Comunicações & & & & \\
\hline 37 & Instituições financeiras & & & & \\
\hline 38 & Serviços prestados às famílias & & & & \\
\hline 39 & Serviços prestados às empresas & & & & \\
\hline 40 & Aluguel de imóveis & & & & \\
\hline 41 & Administração pública & & & & \\
\hline 42 & Serviços privados não-mercantis & & & & \\
\hline
\end{tabular}


ANEXO D - Percentual de pessoas ocupadas por gênero nos macro setores - 1990/1995.

\begin{tabular}{|c|c|c|c|c|c|c|c|c|}
\hline & \multicolumn{2}{|c|}{1990} & \multicolumn{2}{|c|}{1992} & \multicolumn{2}{|c|}{1993} & \multicolumn{2}{|c|}{1995} \\
\hline & Masculino & Feminino & Masculino & Feminino & Masculino & Feminino & Masculino & Feminino \\
\hline Agropecuária & 88,10 & 11,90 & 85,55 & 14,45 & 83,95 & 16,05 & 68,34 & 31,66 \\
\hline Extrativa mineral (exc. & & & & & & & & \\
\hline Combustíveis) & 92,23 & 7,77 & 90,72 & 9,28 & 94,64 & 5,36 & 98,04 & 1,96 \\
\hline Ext. de petróleo, gás nat. & & & & & & & & \\
\hline e outros combustíveis & 92,31 & 7,69 & 89,61 & 10,39 & 86,80 & 13,20 & 96,14 & 3,86 \\
\hline $\begin{array}{l}\text { Indústria } \\
\text { Serviços industriais de u }\end{array}$ & 65,12 & 34,88 & 64,17 & 35,83 & 63,04 & 36,96 & 60,83 & 39,17 \\
\hline pública & 97,51 & 2,49 & 97,02 & 2,98 & 96,09 & 3,91 & 90,01 & 9,99 \\
\hline Construção civil & 87,95 & 12,05 & 83,62 & 16,38 & 83,31 & 16,69 & 74,48 & 25,52 \\
\hline Serviços & 51,01 & 48,99 & 49,58 & 50,42 & 51,49 & 48,51 & 51,12 & 48,88 \\
\hline
\end{tabular}

Fonte: Dados da pesquisa.

ANEXO E - Percentual de pessoas ocupadas por gênero nos macro setores - 1996 - 1999.

\begin{tabular}{|c|c|c|c|c|c|c|c|c|}
\hline & \multicolumn{2}{|c|}{1996} & \multicolumn{2}{|c|}{1997} & \multicolumn{2}{|c|}{1998} & \multicolumn{2}{|c|}{1999} \\
\hline & Masculino & Feminino & Masculino & Feminino & Masculino & Feminino & Masculino & Feminino \\
\hline Agropecuária & 89,09 & 10,91 & 87,33 & 12,67 & 85,56 & 14,44 & 84,92 & 15,08 \\
\hline \multicolumn{9}{|l|}{ Extrativa mineral (exc. } \\
\hline Combustíveis) & 93,17 & 6,83 & 92,08 & 7,92 & 91,45 & 8,55 & 93,36 & 6,64 \\
\hline \multicolumn{9}{|c|}{ Ext. de petróleo, gás nat.,carvão } \\
\hline e outros combustíveis & 88,19 & 11,81 & 94,36 & 5,64 & 87,37 & 12,63 & 90,47 & 9,53 \\
\hline Indústria & 63,87 & 36,13 & 63,97 & 36,03 & 64,04 & 35,96 & 63,36 & 36,64 \\
\hline \multicolumn{9}{|c|}{ Serviços industriais de utilidade } \\
\hline pública & 97,61 & 2,39 & 97,87 & 2,13 & 96,12 & 3,88 & 96,10 & 3,90 \\
\hline Construção civil & 84,53 & 15,47 & 85,13 & 14,87 & 83,15 & 16,85 & 86,20 & 13,80 \\
\hline Serviços & 51,18 & 48,82 & 51,77 & 48,23 & 52,55 & 47,45 & 51,63 & 48,37 \\
\hline
\end{tabular}

Fonte: Dados da pesquisa. 
ANEXO F - Percentual de pessoas ocupadas por gênero em relação ao total (por gênero) da mão-de-obra ocupada - 1990/1995.

\begin{tabular}{|c|c|c|c|c|c|c|c|c|}
\hline & \multicolumn{2}{|c|}{1990} & \multicolumn{2}{|c|}{1992} & \multicolumn{2}{|c|}{1993} & \multicolumn{2}{|c|}{1995} \\
\hline & Masculino & Feminino & Masculino & Feminino & Masculino & Feminino & Masculino & Feminino \\
\hline Agropecuária & 33,87 & 8,97 & 34,98 & 10,61 & 33,93 & 11,84 & 28,60 & 19,21 \\
\hline $\begin{array}{l}\text { Extrativa mineral (exc. } \\
\text { Combustíveis) }\end{array}$ & 0,72 & 0,12 & 0,62 & 0,11 & 0,66 & 0,07 & 0,62 & 0,02 \\
\hline $\begin{array}{l}\text { Ext. de petróleo, gás nat.,carvão e } \\
\text { outros combustíveis }\end{array}$ & 0,08 & 0,01 & 0,08 & 0,02 & 0,07 & 0,02 & 0,08 & 0,00 \\
\hline $\begin{array}{l}\text { Indústria } \\
\text { Serviços industriais de utilidade }\end{array}$ & 15,26 & 16,01 & 14,33 & 14,37 & 13,52 & 14,47 & 13,92 & 12,99 \\
\hline pública & 9,90 & 0,49 & 8,75 & 0,48 & 8,86 & 0,66 & 8,52 & 1,37 \\
\hline Construção civil & 0,73 & 0,20 & 0,64 & 0,22 & 0,68 & 0,25 & 0,52 & 0,26 \\
\hline Serviços & 39,44 & 74,20 & 40,60 & 74,18 & 42,28 & 72,69 & 47,73 & 66,14 \\
\hline
\end{tabular}

Fonte: Dados da pesquisa.

ANEXO G - Percentual de pessoas ocupadas por gênero em relação ao total (por gênero) da mão-de-obra ocupada - 1996-1999.

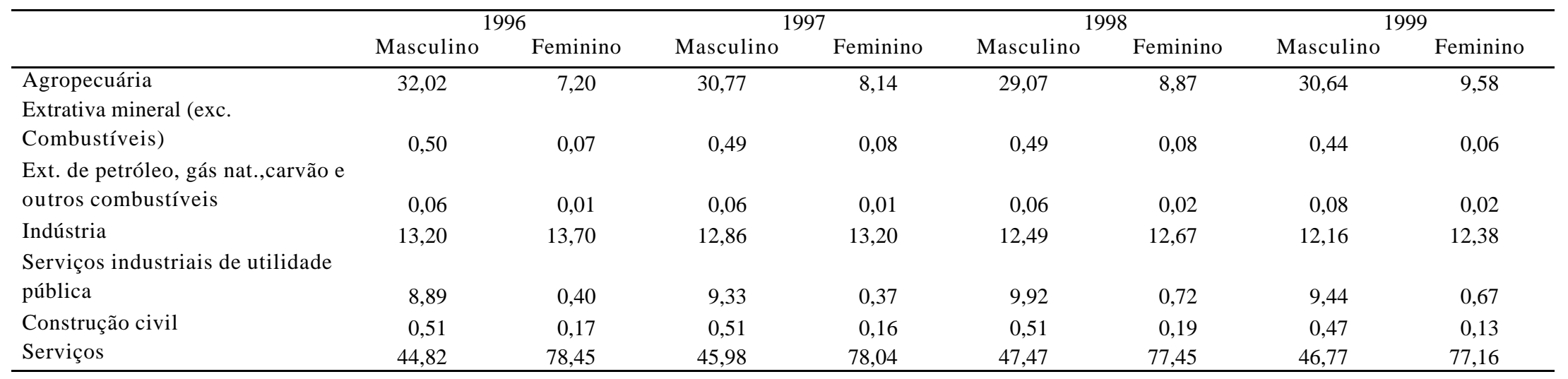

Fonte: Dados da pesquisa. 
ANEXO H - Situação ocupacional em relação ao total da mão-de-obra ocupada no macro setor (\%) - 1990/1999.

\begin{tabular}{|c|c|c|c|c|c|c|c|c|}
\hline & 1990 & 1992 & 1993 & 1995 & 1996 & 1997 & 1998 & 1999 \\
\hline \multicolumn{9}{|l|}{ Agropecuária } \\
\hline Empregado com carteira & 48,02 & 11,06 & 21,17 & 6,87 & 8,86 & 10,51 & 10,95 & 9,78 \\
\hline Empregado sem carteira & 5,77 & 17,86 & 17,21 & 12,07 & 14,21 & 49,15 & 42,01 & 44,32 \\
\hline Funcionário público & $\ldots$ & 2,02 & 3,71 & 0,78 & 2,68 & 17,73 & 27,72 & 24,69 \\
\hline Conta própria & 39,68 & 55,89 & 45,91 & 68,69 & 62,54 & 12,31 & 12,45 & 13,80 \\
\hline Empregador & 3,69 & 2,26 & 5,40 & 7,13 & 3,25 & 10,31 & 6,78 & 7,41 \\
\hline Não remunerado ou sem declaração & 2,84 & 10,91 & 6,60 & 4,47 & 8,47 & 0,00 & 0,09 & 0,00 \\
\hline \multicolumn{9}{|c|}{ Extrativa mineral (exceto combustíveis) } \\
\hline Empregado com carteira & 74,67 & 35,81 & 35,90 & 30,48 & 33,16 & 35,69 & 40,89 & 30,20 \\
\hline Empregado sem carteira & 0,00 & 23,40 & 36,41 & 15,43 & 29,47 & 17,58 & 16,87 & 22,72 \\
\hline Funcionário público & $\ldots$ & 0,00 & 0,24 & 0,04 & 0,00 & 37,90 & 31,04 & 35,83 \\
\hline Conta própria & 17,92 & 25,62 & 17,92 & 14,12 & 29,44 & 8,83 & 11,21 & 11,24 \\
\hline Empregador & 6,18 & 3,11 & 5,56 & 38,02 & 4,83 & 0,00 & 0,00 & 0,00 \\
\hline Não remunerado ou sem declaração & 1,23 & 12,07 & 3,97 & 1,92 & 3,10 & 0,00 & 0,00 & 0,00 \\
\hline \multicolumn{9}{|c|}{ Ext. de petróleo, gás nat.,carvão e outros comb. } \\
\hline Empregado com carteira & 99,47 & 88,26 & 88,76 & 86,23 & 84,41 & 79,69 & 82,05 & 86,70 \\
\hline Empregado sem carteira & 0,00 & 4,46 & 3,79 & 0,51 & 2,84 & 0,00 & 2,63 & 0,00 \\
\hline Funcionário público & $\ldots$ & 7,27 & 7,45 & 13,26 & 12,74 & 20,31 & 12,70 & 11,83 \\
\hline Conta própria & 0,53 & 0,00 & 0,00 & 0,00 & 0,00 & 0,00 & 2,63 & 1,47 \\
\hline Empregador & 0,00 & 0,00 & 0,00 & 0,00 & 0,00 & 0,00 & 0,00 & 0,00 \\
\hline Não remunerado ou sem declaração & 0,00 & 0,00 & 0,00 & 0,00 & 0,00 & 0,00 & 0,00 & 0,00 \\
\hline \multicolumn{9}{|l|}{ Indústria } \\
\hline Empregado com carteira & 77,84 & 58,13 & 59,84 & 48,28 & 56,73 & 56,45 & 56,06 & 55,60 \\
\hline Empregado sem carteira & 0,00 & 17,84 & 15,05 & 12,27 & 17,19 & 18,40 & 19,27 & 19,05 \\
\hline Funcionário público & $\ldots$ & 0,07 & 0,22 & 0,07 & 0,24 & 17,49 & 17,05 & 17,53 \\
\hline Conta própria & 16,07 & 17,59 & 17,52 & 25,61 & 18,54 & 7,67 & 7,62 & 7,82 \\
\hline Empregador & 4,31 & 3,18 & 4,47 & 10,05 & 4,30 & 0,00 & 0,00 & 0,00 \\
\hline Não remunerado ou sem declaração & 1,78 & 3,18 & 2,90 & 3,73 & 3,00 & 0,00 & 0,00 & 0,00 \\
\hline \multicolumn{9}{|l|}{ Construção civil } \\
\hline Empregado com carteira & 63,42 & 32,05 & 30,38 & 27,96 & 23,93 & 23,44 & 20,99 & 20,11 \\
\hline Empregado sem carteira & 0,00 & 28,61 & 25,84 & 22,33 & 27,62 & 40,06 & 38,92 & 40,99 \\
\hline Funcionário público & $\ldots$ & 0,25 & 0,32 & 0,50 & 0,51 & 27,19 & 31,65 & 31,03 \\
\hline Conta própria & 30,40 & 35,52 & 37,58 & 36,76 & 43,46 & 9,31 & 8,44 & 7,87 \\
\hline Empregador & 4,95 & 2,24 & 4,47 & 10,34 & 2,72 & 0,00 & 0,00 & 0,00 \\
\hline Não remunerado ou sem declaração & 1,23 & 1,34 & 1,41 & 2,12 & 1,77 & 0,00 & 0,00 & 0,00 \\
\hline \multicolumn{9}{|c|}{ Serviços indust. de utilidade pública } \\
\hline Empregado com carteira & 99,70 & 75,79 & 76,26 & 77,34 & 67,97 & 69,95 & 73,84 & 75,43 \\
\hline Empregado sem carteira & 0,00 & 5,67 & 4,24 & 7,63 & 6,10 & 0,00 & 0,00 & 0,15 \\
\hline Funcionário público & $\ldots$ & 18,54 & 19,27 & 11,66 & 25,42 & 29,93 & 25,87 & 23,94 \\
\hline Conta própria & 0,12 & 0,00 & 0,00 & 0,00 & 0,00 & 0,12 & 0,29 & 0,48 \\
\hline Empregador & 0,00 & 0,00 & 0,10 & 3,25 & 0,00 & 0,00 & 0,00 & 0,00 \\
\hline Não remunerado ou sem declaração & 0,18 & 0,00 & 0,13 & 0,12 & 0,51 & 0,00 & 0,00 & 0,00 \\
\hline \multicolumn{9}{|l|}{ Serviços } \\
\hline Empregado com carteira & 68,69 & 34,23 & 30,92 & 24,18 & 32,45 & 40,75 & 38,92 & 37,49 \\
\hline Empregado sem carteira & 0,00 & 24,92 & 23,92 & 24,02 & 25,40 & 30,03 & 32,26 & 33,42 \\
\hline Funcionário público & $\ldots$ & 11,39 & 12,23 & 10,40 & 9,98 & 22,35 & 22,19 & 22,51 \\
\hline Conta própria & 25,13 & 24,86 & 26,45 & 31,72 & 25,97 & 6,86 & 6,64 & 6,58 \\
\hline Empregador & 4,49 & 2,01 & 4,15 & 7,30 & 3,77 & 0,00 & 0,00 & 0,00 \\
\hline Não remunerado ou sem declaração & 1,68 & 2,59 & 2,33 & 2,38 & 2,43 & 0,00 & 0,00 & 0,00 \\
\hline
\end{tabular}

Fonte: Dados da pesquisa. 
ANEXO I - Mão-de-obra ocupada no macro setor por tipo de ocupação (\%) - 1990/1999.

\begin{tabular}{|c|c|c|c|c|c|c|c|c|}
\hline & 1990 & 1992 & 1993 & 1995 & 1996 & 1997 & 1998 & 1999 \\
\hline & \multicolumn{8}{|c|}{ Empregado com carteira } \\
\hline Agropecuária & 18,89 & 9,26 & 16,94 & 7,19 & 6,90 & 6,84 & 7,06 & 6,95 \\
\hline Extrativa mineral (exc.combustíveis) & 0,59 & 0,50 & 0,49 & 0,48 & 0,38 & 0,35 & 0,41 & 0,28 \\
\hline Ext. de petróleo, gás nat.,carvão e outros combustíveis & 0,09 & 0,15 & 0,13 & 0,18 & 0,12 & 0,09 & 0,11 & 0,16 \\
\hline Indústria & 18,66 & 25,64 & 25,40 & 27,65 & 25,41 & 20,96 & 20,75 & 21,02 \\
\hline Serviços industrias de utilidade pública & 6,58 & 5,92 & 5,54 & 6,62 & 4,72 & 4,13 & 4,11 & 3,89 \\
\hline Construção civil & 0,85 & 1,18 & 1,23 & 1,36 & 0,88 & 0,78 & 0,85 & 0,80 \\
\hline Serviços & 54,33 & 57,35 & 50,25 & 56,50 & 61,58 & 66,85 & 66,71 & 66,90 \\
\hline \multirow[t]{2}{*}{ TOTAL } & 100,00 & 100,00 & 100,00 & 100,00 & 100,00 & 100,00 & 100,00 & 100,00 \\
\hline & \multicolumn{8}{|c|}{ Empregado sem carteira } \\
\hline Agropecuária & $\ldots$ & 21,26 & 21,40 & 15,52 & 15,19 & 33,56 & 27,84 & 29,58 \\
\hline Extrativa mineral (exc.combustíveis) & $\ldots$ & 0,47 & 0,78 & 0,30 & 0,47 & 0,18 & 0,17 & 0,20 \\
\hline Ext. de petróleo, gás nat.,carvão e outros combustíveis & $\ldots$ & 0,01 & 0,01 & 0,00 & 0,01 & 0,00 & 0,00 & 0,00 \\
\hline Indústria & $\ldots$ & 11,20 & 9,94 & 8,62 & 10,57 & 7,17 & 7,33 & 6,76 \\
\hline Serviços industrias de utilidade pública & $\ldots$ & 7,52 & 7,33 & 6,49 & 7,48 & 7,40 & 7,83 & 7,45 \\
\hline Construção civil & $\ldots$ & 0,13 & 0,11 & 0,17 & 0,11 & 0,00 & 0,00 & 0,00 \\
\hline Serviços & $\ldots$ & 59,42 & 60,44 & 68,90 & 66,17 & 51,69 & 56,82 & 56,01 \\
\hline \multirow[t]{2}{*}{ TOTAL } & $\ldots$ & 100,00 & 100,00 & 100,00 & 100,00 & 100,00 & 100,00 & 100,00 \\
\hline & \multicolumn{8}{|c|}{ Funcionário público } \\
\hline Agropecuária & $\ldots$ & 7,98 & 12,74 & 3,19 & 9,66 & 19,16 & 25,89 & 24,73 \\
\hline Extrativa mineral (exc.combustíveis) & $\ldots$ & 0,00 & 0,01 & 0,00 & 0,00 & 0,61 & 0,45 & 0,47 \\
\hline Ext. de petróleo, gás nat.,carvão e outros combustíveis & $\ldots$ & 0,06 & 0,05 & 0,11 & 0,09 & 0,04 & 0,02 & 0,03 \\
\hline Indústria & $\ldots$ & 0,15 & 0,39 & 0,16 & 0,50 & 10,79 & 9,14 & 9,34 \\
\hline Serviços industrias de utilidade pública & $\ldots$ & 0,22 & 0,25 & 0,46 & 0,47 & 7,95 & 8,98 & 8,46 \\
\hline Construção civil & $\ldots$ & 1,36 & 1,34 & 0,80 & 1,53 & 0,55 & 0,43 & 0,36 \\
\hline Serviços & $\ldots$ & 90,23 & 85,21 & 95,27 & 87,74 & 60,89 & 55,08 & 56,60 \\
\hline \multirow[t]{2}{*}{ TOTAL } & $\ldots$ & 100,00 & 100,00 & 100,00 & 100,00 & 100,00 & 100,00 & 100,00 \\
\hline & \multicolumn{8}{|c|}{ Conta própria } \\
\hline Agropecuária & 36,60 & 45,36 & 38,97 & 42,41 & 42,28 & 33,61 & 33,45 & 37,52 \\
\hline Extrativa mineral (exc.combustíveis) & 0,33 & 0,35 & 0,26 & 0,13 & 0,30 & 0,36 & 0,47 & 0,40 \\
\hline Ext. de petróleo, gás nat.,carvão e outros combustíveis & 0,00 & 0,00 & 0,00 & 0,00 & 0,00 & 0,00 & 0,01 & 0,01 \\
\hline Indústria & 9,04 & 7,53 & 7,89 & 8,65 & 7,20 & 11,95 & 11,75 & 11,30 \\
\hline Serviços industrias de utilidade pública & 7,40 & 6,36 & 7,27 & 5,13 & 7,44 & 6,88 & 6,89 & 5,82 \\
\hline Construção civil & 0,00 & 0,00 & 0,00 & 0,00 & 0,00 & 0,01 & 0,01 & 0,02 \\
\hline Serviços & 46,62 & 40,40 & 45,61 & 43,68 & 42,77 & 47,20 & 47,42 & 44,92 \\
\hline \multirow[t]{2}{*}{ TOTAL } & 100,00 & 100,00 & 100,00 & 100,00 & 100,00 & 100,00 & 100,00 & 100,00 \\
\hline & \multicolumn{8}{|c|}{ Empregador } \\
\hline Agropecuária & 22,01 & 26,60 & 31,18 & 22,37 & 20,71 & 100,00 & 100,00 & 100,00 \\
\hline Extrativa mineral (exc.combustíveis) & 0,74 & 0,61 & 0,55 & 1,81 & 0,46 & 0,00 & 0,00 & 0,00 \\
\hline Ext. de petróleo, gás nat.,carvão e outros combustíveis & 0,00 & 0,00 & 0,00 & 0,00 & 0,00 & 0,00 & 0,00 & 0,00 \\
\hline Indústria & 15,66 & 19,72 & 13,70 & 17,23 & 15,76 & 0,00 & 0,00 & 0,00 \\
\hline Serviços industrias de utilidade pública & 7,78 & 5,82 & 5,88 & 7,33 & 4,39 & 0,00 & 0,00 & 0,00 \\
\hline Construção civil & 0,00 & 0,00 & 0,01 & 0,17 & 0,00 & 0,00 & 0,00 & 0,00 \\
\hline Serviços & 53,81 & 47,25 & 48,67 & 51,09 & 58,68 & 0,00 & 0,00 & 0,00 \\
\hline \multirow[t]{2}{*}{ TOTAL } & 100,00 & 100,00 & 100,00 & 100,00 & 100,00 & 100,00 & 100,00 & 100,00 \\
\hline & \multicolumn{8}{|c|}{ Não remunerado ou sem declaração } \\
\hline Agropecuária & 37,08 & 59,69 & 49,76 & 36,28 & 50,94 & 0,00 & 100,00 & 0,00 \\
\hline Extrativa mineral (exc.combustíveis) & 0,32 & 1,10 & 0,52 & 0,24 & 0,28 & 0,00 & 0,00 & 0,00 \\
\hline Ext. de petróleo, gás nat.,carvão e outros combustíveis & 0,00 & 0,00 & 0,00 & 0,00 & 0,00 & 0,00 & 0,00 & 0,00 \\
\hline Indústria & 14,15 & 9,18 & 11,62 & 16,54 & 10,37 & 0,00 & 0,00 & 0,00 \\
\hline Serviços industrias de utilidade pública & 4,24 & 1,61 & 2,42 & 3,88 & 2,69 & 0,00 & 0,00 & 0,00 \\
\hline Construção civil & 0,05 & 0,00 & 0,02 & 0,02 & 0,05 & 0,00 & 0,00 & 0,00 \\
\hline Serviços & 44,15 & 28,41 & 35,67 & 43,04 & 35,66 & 0,00 & 0,00 & 0,00 \\
\hline TOTAL & 100,00 & 100,00 & 100,00 & 100,00 & 100,00 & 0,00 & 100,00 & 0,00 \\
\hline
\end{tabular}

Fonte: dados da pesquisa 
ANEXO J - Idade de ingresso da mão-de-obra ocupada no mercado de trabalho (\%) - 1990/1999.

\begin{tabular}{|c|c|c|c|c|c|c|c|c|}
\hline & 1990 & 1992 & 1993 & 1995 & 1996 & 1997 & 1998 & 1999 \\
\hline \multicolumn{9}{|l|}{ Agropecuária } \\
\hline Até 14 anos & $\ldots$ & 75,02 & 68,07 & 81,19 & 77,07 & 81,66 & 82,57 & 83,40 \\
\hline 15 a 19 anos & $\ldots$ & 22,00 & 25,61 & 11,45 & 18,75 & 15,51 & 14,86 & 14,85 \\
\hline 20 a 24 anos & $\ldots$ & 2,62 & 4,97 & 3,03 & 3,41 & 2,05 & 1,92 & 1,35 \\
\hline 25 a 29 anos & $\ldots$ & 0,36 & 1,31 & 2,28 & 0,67 & 0,60 & 0,41 & 0,40 \\
\hline 30 a 39 anos & $\ldots$ & 0,00 & 0,03 & 2,06 & 0,10 & 0,08 & 0,23 & 0,00 \\
\hline 40 anos ou mais & $\ldots$ & 0,00 & 0,00 & 0,00 & 0,00 & 0,09 & 0,00 & 0,00 \\
\hline \multicolumn{9}{|c|}{ Extrativa mineral (exceto combustíveis) } \\
\hline Até 14 anos & $\ldots$ & 78,09 & 81,90 & 48,41 & 82,33 & 79,01 & 80,20 & 76,36 \\
\hline 15 a 19 anos & $\ldots$ & 18,83 & 17,39 & 39,19 & 17,27 & 17,60 & 18,42 & 22,41 \\
\hline 20 a 24 anos & $\ldots$ & 2,54 & 0,71 & 0,23 & 0,40 & 2,54 & 1,38 & 1,03 \\
\hline 25 a 29 anos & $\ldots$ & 0,00 & 0,00 & 12,17 & 0,00 & 0,00 & 0,00 & 0,20 \\
\hline 30 a 39 anos & $\ldots$ & 0,53 & 0,00 & 0,00 & 0,00 & 0,85 & 0,00 & 0,00 \\
\hline 40 anos ou mais & $\ldots$ & 0,00 & 0,00 & 0,00 & 0,00 & 0,00 & 0,00 & 0,00 \\
\hline \multicolumn{9}{|c|}{ Ext. de petróleo, gás nat.,carvão e outros comb. } \\
\hline Até 14 anos & $\ldots$ & 34,76 & 39,35 & 27,80 & 37,26 & 40,85 & 36,11 & 35,85 \\
\hline 15 a 19 anos & $\ldots$ & 52,23 & 35,63 & 54,11 & 42,57 & 45,99 & 39,53 & 44,27 \\
\hline 20 a 24 anos & $\cdots$ & 11,22 & 21,58 & 17,23 & 19,05 & 10,03 & 17,01 & 17,21 \\
\hline 25 a 29 anos & $\ldots$ & 1,80 & 3,44 & 0,86 & 0,00 & 3,13 & 7,35 & 2,66 \\
\hline 30 a 39 anos & $\ldots$ & 0,00 & 0,00 & 0,00 & 0,00 & 0,00 & 0,00 & 0,00 \\
\hline 40 anos ou mais & $\cdots$ & 0,00 & 0,00 & 0,00 & 1,12 & 0,00 & 0,00 & 0,00 \\
\hline \multicolumn{9}{|l|}{ Indústria } \\
\hline Até 14 anos & $\ldots$ & 62,84 & 60,78 & 53,96 & 62,40 & 61,33 & 63,08 & 60,95 \\
\hline 15 a 19 anos & $\ldots$ & 30,39 & 32,60 & 37,33 & 31,50 & 32,81 & 31,00 & 33,24 \\
\hline 20 a 24 anos & $\ldots$ & 4,90 & 5,06 & 6,11 & 4,50 & 4,51 & 4,53 & 4,60 \\
\hline 25 a 29 anos & $\ldots$ & 1,00 & 0,86 & 1,24 & 0,82 & 0,71 & 0,77 & 0,67 \\
\hline 30 a 39 anos & $\cdots$ & 0,65 & 0,56 & 1,29 & 0,58 & 0,50 & 0,48 & 0,43 \\
\hline 40 anos ou mais & $\ldots$ & 0,22 & 0,15 & 0,07 & 0,21 & 0,14 & 0,10 & 0,11 \\
\hline \multicolumn{9}{|l|}{ Construção civil } \\
\hline Até 14 anos & $\ldots$ & 70,40 & 69,43 & 68,19 & 71,11 & 71,05 & 72,16 & 71,29 \\
\hline 15 a 19 anos & $\ldots$ & 26,51 & 26,96 & 26,59 & 26,35 & 26,27 & 25,40 & 26,27 \\
\hline 20 a 24 anos & $\ldots$ & 2,71 & 3,09 & 4,51 & 2,28 & 2,35 & 2,22 & 2,12 \\
\hline 25 a 29 anos & $\ldots$ & 0,25 & 0,36 & 0,68 & 0,25 & 0,27 & 0,16 & 0,26 \\
\hline 30 a 39 anos & $\ldots$ & 0,13 & 0,17 & 0,02 & 0,01 & 0,03 & 0,05 & 0,04 \\
\hline 40 anos ou mais & $\ldots$ & 0,00 & 0,00 & 0,01 & 0,00 & 0,02 & 0,01 & 0,01 \\
\hline \multicolumn{9}{|c|}{ Serviços industriais e de utilidade pública } \\
\hline Até 14 anos & $\cdots$ & 44,51 & 48,04 & 35,33 & 21,38 & 55,22 & 49,22 & 45,30 \\
\hline 15 a 19 anos & $\ldots$ & 42,28 & 41,37 & 35,68 & 62,45 & 34,16 & 38,18 & 42,43 \\
\hline 20 a 24 anos & $\ldots$ & 11,19 & 9,70 & 24,50 & 14,31 & 9,12 & 10,70 & 10,50 \\
\hline 25 a 29 anos & $\cdots$ & 1,74 & 0,65 & 4,05 & 1,69 & 1,43 & 1,43 & 1,67 \\
\hline 30 a 39 anos & $\ldots$ & 0,29 & 0,25 & 0,38 & 0,16 & 0,00 & 0,11 & 0,10 \\
\hline 40 anos ou mais & & 0,00 & 0,00 & 0,07 & 0,00 & 0,06 & 0,37 & 0,00 \\
\hline \multicolumn{9}{|l|}{ Serviços } \\
\hline Até 14 anos & $\cdots$ & 53,11 & 50,37 & 45,34 & 53,10 & 53,25 & 54,02 & 52,60 \\
\hline 15 a 19 anos & $\ldots$ & 33,84 & 36,91 & 38,12 & 35,00 & 35,89 & 34,82 & 36,49 \\
\hline 20 a 24 anos & $\ldots$ & 9,21 & 9,35 & 12,39 & 8,75 & 8,25 & 8,45 & 8,14 \\
\hline 25 a 29 anos & $\cdots$ & 2,54 & 2,00 & 2,96 & 1,89 & 1,52 & 1,60 & 1,50 \\
\hline 30 a 39 anos & $\ldots$ & 0,99 & 1,03 & 0,87 & 1,00 & 0,83 & 0,84 & 0,76 \\
\hline 40 anos ou mais & $\ldots$ & 0,30 & 0,34 & 0,33 & 0,25 & 0,27 & 0,23 & 0,51 \\
\hline
\end{tabular}

Fonte: Dados da pesquisa. 
ANEXO K - Mão-de-obra empregada por idade de ingresso no mercado de trabalho-1990/1999.

\begin{tabular}{|c|c|c|c|c|c|c|c|c|}
\hline & 1990 & 1992 & 1993 & 1995 & 1996 & 1997 & 1998 & 1999 \\
\hline & \multicolumn{8}{|c|}{ até 14 anos } \\
\hline Agropecuária & $\ldots$ & 32,30 & 30,81 & 35,51 & 29,42 & 29,99 & 28,82 & 31,00 \\
\hline Extrativa mineral (exc.combustíveis) & $\ldots$ & 0,56 & 0,64 & 0,32 & 0,47 & 0,43 & 0,44 & 0,37 \\
\hline Ext. de petróleo, gás nat.,carvão e outros combustíveis & $\ldots$ & 0,03 & 0,03 & 0,02 & 0,03 & 0,03 & 0,03 & 0,03 \\
\hline Indústria & $\ldots$ & 14,26 & 14,60 & 12,91 & 13,69 & 12,85 & 12,64 & 12,05 \\
\hline Serviços industrias e de utilidade pública & $\ldots$ & 6,69 & 7,16 & 6,74 & 6,88 & 7,06 & 7,65 & 7,21 \\
\hline Construção civil & $\ldots$ & 0,36 & 0,44 & 0,26 & 0,14 & 0,35 & 0,31 & 0,25 \\
\hline Serviços & $\ldots$ & 45,80 & 46,32 & 44,24 & 49,38 & 49,29 & 50,12 & 49,08 \\
\hline \multirow[t]{2}{*}{ TOTAL } & $\ldots$ & 100,00 & 100,00 & 100,00 & 100,00 & 100,00 & 100,00 & 100,00 \\
\hline & \multicolumn{8}{|c|}{15 a 19 anos } \\
\hline Agropecuária & $\ldots$ & 19,49 & 20,45 & 9,22 & 14,40 & 11,69 & 11,09 & 11,22 \\
\hline Extrativa mineral (exc.combustíveis) & $\ldots$ & 0,28 & 0,24 & 0,48 & 0,20 & 0,20 & 0,21 & 0,22 \\
\hline Ext. de petróleo, gás nat.,carvão e outros combustíveis & $\ldots$ & 0,10 & 0,05 & 0,09 & 0,06 & 0,06 & 0,06 & 0,09 \\
\hline Indústria & $\ldots$ & 14,20 & 13,81 & 16,43 & 13,91 & 14,11 & 13,28 & 13,36 \\
\hline Serviços industrias e de utilidade pública & $\ldots$ & 5,18 & 4,91 & 4,84 & 5,13 & 5,36 & 5,76 & 5,40 \\
\hline Construção civil & $\ldots$ & 0,70 & 0,67 & 0,48 & 0,80 & 0,44 & 0,51 & 0,48 \\
\hline Serviços & $\ldots$ & 60,05 & 59,87 & 68,46 & 65,50 & 68,15 & 69,09 & 69,22 \\
\hline \multirow[t]{2}{*}{ TOTAL } & $\ldots$ & 100,00 & 100,00 & 100,00 & 100,00 & 100,00 & 100,00 & 100,00 \\
\hline & \multicolumn{8}{|c|}{20 a 24 anos } \\
\hline Agropecuária & $\ldots$ & 10,68 & 18,02 & 8,53 & 12,11 & 7,81 & 6,88 & 5,39 \\
\hline Extrativa mineral (exc.combustíveis) & $\ldots$ & 0,17 & 0,04 & 0,01 & 0,02 & 0,15 & 0,08 & 0,05 \\
\hline Ext. de petróleo, gás nat.,carvão e outros combustíveis & $\ldots$ & 0,10 & 0,15 & 0,10 & 0,13 & 0,07 & 0,12 & 0,18 \\
\hline Indústria & $\ldots$ & 10,54 & 9,72 & 9,41 & 9,17 & 9,81 & 9,32 & 9,78 \\
\hline Serviços industrias e de utilidade pública & $\ldots$ & 2,43 & 2,55 & 2,88 & 2,05 & 2,42 & 2,42 & 2,31 \\
\hline Construção civil & $\ldots$ & 0,85 & 0,71 & 1,16 & 0,85 & 0,59 & 0,69 & 0,63 \\
\hline Serviços & $\ldots$ & 75,23 & 68,81 & 77,91 & 75,66 & 79,15 & 80,49 & 81,66 \\
\hline \multirow[t]{2}{*}{ TOTAL } & $\ldots$ & 100,00 & 100,00 & 100,00 & 100,00 & 100,00 & 100,00 & 100,00 \\
\hline & \multicolumn{8}{|c|}{25 a 29 anos } \\
\hline Agropecuária & $\ldots$ & 5,88 & 22,15 & 22,86 & 11,44 & 12,23 & 7,92 & 8,62 \\
\hline Extrativa mineral (exc.combustíveis) & $\ldots$ & 0,00 & 0,00 & 1,86 & 0,00 & 0,00 & 0,00 & 0,06 \\
\hline Ext. de petróleo, gás nat.,carvão e outros combustíveis & $\ldots$ & 0,06 & 0,11 & 0,02 & 0,00 & 0,12 & 0,29 & 0,15 \\
\hline Indústria & $\ldots$ & 8,71 & 7,67 & 6,78 & 8,08 & 8,18 & 8,51 & 7,67 \\
\hline Serviços industrias e de utilidade pública & $\ldots$ & 0,92 & 1,38 & 1,54 & 1,08 & 1,51 & 0,94 & 1,54 \\
\hline Construção civil & $\cdots$ & 0,53 & 0,22 & 0,68 & 0,48 & 0,50 & 0,49 & 0,54 \\
\hline Serviços & $\ldots$ & 83,89 & 68,48 & 66,26 & 78,92 & 77,47 & 81,85 & 81,43 \\
\hline \multirow[t]{2}{*}{ TOTAL } & $\ldots$ & 100,00 & 100,00 & 100,00 & 100,00 & 100,00 & 100,00 & 100,00 \\
\hline & \multicolumn{8}{|c|}{30 a 39 anos } \\
\hline Agropecuária & $\ldots$ & 0,00 & 1,26 & 43,75 & 3,47 & 3,37 & 8,55 & 0,00 \\
\hline Extrativa mineral (exc.combustíveis) & $\ldots$ & 0,37 & 0,00 & 0,00 & 0,00 & 0,51 & 0,00 & 0,00 \\
\hline Ext. de petróleo, gás nat.,carvão e outros combustíveis & $\cdots$ & 0,00 & 0,00 & 0,00 & 0,00 & 0,00 & 0,00 & 0,00 \\
\hline Indústria & $\ldots$ & 14,39 & 12,08 & 14,99 & 11,55 & 11,40 & 9,98 & 10,65 \\
\hline Serviços industrias e de utilidade pública & $\ldots$ & 1,17 & 1,54 & 0,11 & 0,05 & 0,34 & 0,54 & 0,54 \\
\hline Construção civil & $\ldots$ & 0,22 & 0,20 & 0,13 & 0,09 & 0,00 & 0,07 & 0,07 \\
\hline Serviços & $\ldots$ & 83,84 & 84,92 & 41,02 & 84,83 & 84,37 & 80,85 & 88,74 \\
\hline \multirow[t]{2}{*}{ TOTAL } & $\ldots$ & 100,00 & 100,00 & 100,00 & 100,00 & 100,00 & 100,00 & 100,00 \\
\hline & \multicolumn{8}{|c|}{40 anos ou mais } \\
\hline Agropecuária & $\ldots$ & 0,00 & 0,00 & 0,00 & 0,00 & 11,05 & 0,00 & 0,00 \\
\hline Extrativa mineral (exc.combustíveis) & $\ldots$ & 0,00 & 0,00 & 0,00 & 0,00 & 0,00 & 0,00 & 0,00 \\
\hline Ext. de petróleo, gás nat.,carvão e outros combustíveis & $\ldots$ & 0,00 & 0,00 & 0,00 & 0,29 & 0,00 & 0,00 & 0,00 \\
\hline Indústria & $\ldots$ & 16,23 & 10,36 & 5,03 & 16,46 & 9,20 & 9,92 & 4,19 \\
\hline Serviços industrias e de utilidade pública & $\ldots$ & 0,00 & 0,00 & 0,20 & 0,00 & 0,56 & 0,38 & 0,20 \\
\hline Construção civil & $\ldots$ & 0,00 & 0,00 & 0,16 & 0,00 & 0,12 & 0,80 & 0,00 \\
\hline Serviços & $\ldots$ & 83,77 & 89,64 & 94,61 & 83,25 & 79,06 & 88,91 & 95,61 \\
\hline TOTAL & $\ldots$ & 100,00 & 100,00 & 100,00 & 100,00 & 100,00 & 100,00 & 100,00 \\
\hline
\end{tabular}

Fonte: Dados da pesquisa. 
ANEXO L - Jornada de trabalho (horas semanais) da mão-de-obra ocupada por macro setor (\%) - 1990/1999.

\begin{tabular}{|c|c|c|c|c|c|c|c|c|}
\hline & 1990 & 1992 & 1993 & 1995 & 1996 & 1997 & 1998 & 1999 \\
\hline \multicolumn{9}{|l|}{ Agropecuária } \\
\hline até 14 horas & 1,01 & 7,92 & 1,98 & 12,56 & 5,98 & 7,11 & 5,68 & 5,58 \\
\hline 15 a 39 horas & 19,24 & 31,32 & 28,08 & 40,71 & 27,71 & 31,27 & 26,39 & 29,91 \\
\hline 40 a 44 horas & 31,34 & 22,92 & 25,18 & 13,72 & 16,22 & 17,57 & 22,25 & 22,40 \\
\hline 45 horas ou mais & 48,40 & 37,52 & 44,76 & 33,00 & 49,33 & 44,05 & 45,42 & 41,93 \\
\hline \multicolumn{9}{|c|}{ Extrativa mineral (exceto combustíveis) } \\
\hline até 14 horas & 0,00 & 2,97 & 0,20 & 0,11 & 1,20 & 0,50 & 2,08 & 1,01 \\
\hline 15 a 39 horas & 9,83 & 17,67 & 8,17 & 0,60 & 4,37 & 9,01 & 10,52 & 11,67 \\
\hline 40 a 44 horas & 41,27 & 37,65 & 43,80 & 55,33 & 36,82 & 40,29 & 34,04 & 37,33 \\
\hline 45 horas ou mais & 48,91 & 41,71 & 47,84 & 43,96 & 57,61 & 50,20 & 53,35 & 49,99 \\
\hline \multicolumn{9}{|c|}{ Ext. de petróleo, gás nat.,carvão e outros comb. } \\
\hline até 14 horas & 0,00 & 0,00 & 0,00 & 0,00 & 1,73 & 0,00 & 0,00 & 0,00 \\
\hline 15 a 39 horas & 16,07 & 4,38 & 7,18 & 12,08 & 7,13 & 8,67 & 15,17 & 10,29 \\
\hline 40 a 44 horas & 54,92 & 61,12 & 55,14 & 37,74 & 48,35 & 38,83 & 53,65 & 57,43 \\
\hline 45 horas ou mais & 29,01 & 34,50 & 37,68 & 50,19 & 42,80 & 52,50 & 31,18 & 32,28 \\
\hline \multicolumn{9}{|l|}{ Indústria } \\
\hline até 14 horas & 0,96 & 2,11 & 2,50 & 5,88 & 2,57 & 2,60 & 2,77 & 2,65 \\
\hline 15 a 39 horas & 13,37 & 15,39 & 13,22 & 15,85 & 13,00 & 13,33 & 12,71 & 13,63 \\
\hline 40 a 44 horas & 51,57 & 44,39 & 45,03 & 44,58 & 42,91 & 45,77 & 44,02 & 45,71 \\
\hline 45 horas ou mais & 34,06 & 38,00 & 39,21 & 33,68 & 41,49 & 38,23 & 40,40 & 37,97 \\
\hline \multicolumn{9}{|l|}{ Construção civil } \\
\hline 15 a 39 horas & 4,61 & 5,73 & 6,74 & 7,20 & 6,86 & 5,81 & 10,27 & 9,20 \\
\hline 40 a 44 horas & 47,46 & 42,73 & 40,11 & 40,47 & 41,70 & 40,88 & 38,40 & 38,92 \\
\hline 45 horas ou mais & 47,71 & 50,15 & 52,18 & 50,85 & 50,08 & 52,20 & 49,47 & 50,18 \\
\hline \multicolumn{8}{|c|}{ Serviços industriais de utilidade pública } & 0,12 \\
\hline 15 a 39 horas & 9,52 & 12,53 & 12,04 & 6,23 & 9,15 & 10,36 & 12,18 & 11,55 \\
\hline 40 a 44 horas & 72,76 & 68,25 & 65,92 & 65,89 & 62,89 & 66,10 & 64,23 & 62,07 \\
\hline 45 horas ou mais & 17,29 & 19,13 & 21,98 & 27,73 & 27,65 & 23,03 & 23,26 & 26,12 \\
\hline \multicolumn{9}{|l|}{ Serviços } \\
\hline até 14 horas & 2,35 & 4,13 & 3,55 & 4,33 & 3,78 & 4,17 & 3,78 & 4,04 \\
\hline 15 a 39 horas & 25,58 & 26,41 & 24,33 & 24,18 & 23,14 & 23,02 & 24,21 & 24,01 \\
\hline 40 a 44 horas & 35,82 & 32,93 & 33,79 & 33,62 & 34,36 & 33,17 & 31,33 & 34,24 \\
\hline 45 horas ou mais & 36,17 & 36,45 & 38,24 & 37,78 & 38,59 & 39,59 & 40,57 & 37,64 \\
\hline
\end{tabular}

Fonte: Dados da pesquisa. 
ANEXO M - Percentual da mão-de-obra ocupada nos macro setores por jornada de trabalho (horas semanais) - 1990/1999.

\begin{tabular}{|c|c|c|c|c|c|c|c|c|}
\hline & 1990 & 1992 & 1993 & 1995 & 1996 & 1997 & 1998 & 1999 \\
\hline & \multicolumn{8}{|c|}{ Até 14 horas } \\
\hline Agropecuária & 15,85 & 44,95 & 18,42 & 48,74 & 33,87 & 36,62 & 31,70 & 31,75 \\
\hline Extrativa mineral (exc.combustíveis) & 0,00 & 0,28 & 0,03 & 0,01 & 0,11 & 0,04 & 0,18 & 0,08 \\
\hline $\begin{array}{l}\text { Ext. de petróleo, gás nat.,carvão e outros } \\
\text { combustíveis }\end{array}$ & 0,00 & 0,00 & 0,00 & 0,00 & 0,02 & 0,00 & 0,00 & 0,00 \\
\hline Indústria & 9,17 & 6,33 & 12,39 & 12,48 & 8,14 & 7,64 & 8,89 & 8,01 \\
\hline Serviços industrias de utilidade pública & 0,55 & 1,53 & 2,00 & 1,29 & 2,23 & 1,52 & 3,05 & 2,53 \\
\hline Construção civil & 0,14 & 0,01 & 0,01 & 0,01 & 0,03 & 0,05 & 0,03 & 0,01 \\
\hline Serviços & 74,28 & 46,91 & 67,15 & 37,47 & 55,60 & 54,14 & 56,15 & 57,62 \\
\hline \multirow[t]{2}{*}{ TOTAL } & 100,00 & 100,00 & 100,00 & 100,00 & 100,00 & 100,00 & 100,00 & 100,00 \\
\hline & \multicolumn{8}{|c|}{15 a 39 horas } \\
\hline Agropecuária & 23,91 & 33,27 & 32,48 & 38,74 & 28,46 & 31,65 & 25,99 & 29,82 \\
\hline Extrativa mineral (exc.combustíveis) & 0,25 & 0,31 & 0,16 & 0,01 & 0,07 & 0,14 & 0,16 & 0,15 \\
\hline $\begin{array}{l}\text { Ext. de petróleo, gás nat.,carvão e outros } \\
\text { combustíveis }\end{array}$ & 0,05 & 0,01 & 0,02 & 0,02 & 0,01 & 0,02 & 0,03 & 0,03 \\
\hline Indústria & 10,13 & 8,62 & 8,11 & 8,25 & 7,45 & 7,70 & 7,18 & 7,23 \\
\hline Serviços industrias de utilidade pública & 1,51 & 1,34 & 1,78 & 1,55 & 2,10 & 1,59 & 3,07 & 2,50 \\
\hline Construção civil & 0,26 & 0,25 & 0,28 & 0,10 & 0,18 & 0,18 & 0,21 & 0,17 \\
\hline Serviços & 63,90 & 56,19 & 57,17 & 51,33 & 61,73 & 58,73 & 63,35 & 60,10 \\
\hline \multirow[t]{2}{*}{ TOTAL } & 100,00 & 100,00 & 100,00 & 100,00 & 100,00 & 100,00 & 100,00 & 100,00 \\
\hline & \multicolumn{8}{|c|}{40 a 44 horas } \\
\hline Agropecuária & 20,91 & 18,52 & 19,51 & 11,04 & 11,29 & 12,54 & 15,43 & 15,46 \\
\hline Extrativa mineral (exc.combustíveis) & 0,56 & 0,51 & 0,58 & 0,68 & 0,40 & 0,43 & 0,37 & 0,34 \\
\hline $\begin{array}{l}\text { Ext. de petróleo, gás nat.,carvão e outros } \\
\text { combustíveis }\end{array}$ & 0,08 & 0,10 & 0,08 & 0,06 & 0,06 & 0,05 & 0,08 & 0,10 \\
\hline Indústria & 20,97 & 18,92 & 18,52 & 19,61 & 16,66 & 18,64 & 17,52 & 16,79 \\
\hline Serviços industrias de utilidade pública & 8,36 & 7,62 & 7,09 & 7,36 & 8,63 & 7,89 & 8,08 & 7,31 \\
\hline Construção civil & 1,05 & 1,03 & 1,03 & 0,89 & 0,84 & 0,81 & 0,80 & 0,64 \\
\hline Serviços & 48,06 & 53,31 & 53,19 & 60,35 & 62,12 & 59,65 & 57,73 & 59,35 \\
\hline \multirow[t]{2}{*}{ TOTAL } & 100,00 & 100,00 & 100,00 & 100,00 & 100,00 & 100,00 & 100,00 & 100,00 \\
\hline & \multicolumn{8}{|c|}{45 horas ou mais } \\
\hline Agropecuária & 31,05 & 26,29 & 28,61 & 22,23 & 26,08 & 24,34 & 23,56 & 24,46 \\
\hline Extrativa mineral (exc.combustíveis) & 0,63 & 0,49 & 0,53 & 0,45 & 0,48 & 0,42 & 0,43 & 0,38 \\
\hline $\begin{array}{l}\text { Ext. de petróleo, gás nat.,carvão e outros } \\
\text { combustíveis }\end{array}$ & 0,04 & 0,05 & 0,05 & 0,07 & 0,04 & 0,05 & 0,03 & 0,05 \\
\hline Indústria & 13,32 & 14,04 & 13,30 & 12,41 & 12,24 & 12,05 & 12,03 & 11,78 \\
\hline Serviços industriais de utilidade pública & 8,08 & 7,75 & 7,60 & 7,75 & 7,88 & 7,80 & 7,79 & 7,97 \\
\hline Construção civil & 0,24 & 0,25 & 0,28 & 0,31 & 0,28 & 0,22 & 0,22 & 0,23 \\
\hline Serviços & 46,64 & 51,14 & 49,64 & 56,78 & 53,00 & 55,12 & 55,94 & 55,13 \\
\hline TOTAL & 100,00 & 100,00 & 100,00 & 100,00 & 100,00 & 100,00 & 100,00 & 100,00 \\
\hline
\end{tabular}

Fonte: Dados da pesquisa. 
ANEXO N - Tempo de serviço da mão-de-obra ocupada por macro setor (\%) - 1990/1999.

\begin{tabular}{|c|c|c|c|c|c|c|c|c|}
\hline & 1990 & 1992 & 1993 & 1995 & 1996 & 1997 & 1998 & 1999 \\
\hline \multicolumn{8}{|l|}{ Agropecuária } & 14,36 \\
\hline 1 a 2 anos & 14,63 & 18,59 & 16,92 & 12,11 & 13,51 & 15,67 & 19,84 & 16,12 \\
\hline 3 a 10 anos & 33,69 & 35,94 & 36,49 & 34,06 & 42,82 & 37,03 & 35,64 & 33,50 \\
\hline 11 a 29 anos & 20,99 & 24,47 & 26,14 & 17,84 & 25,98 & 24,78 & 23,99 & 30,02 \\
\hline 30 a 39 anos & 3,60 & 4,63 & 3,82 & 12,46 & 5,72 & 5,60 & 4,11 & 4,06 \\
\hline 40 anos ou mais & 1,28 & 1,50 & 2,17 & 2,32 & 2,63 & 2,70 & 1,59 & 1,95 \\
\hline \multicolumn{9}{|c|}{ Extrativa mineral (exceto combustíveis) } \\
\hline 1 a 2 anos & 20,54 & 27,09 & 24,29 & 16,39 & 21,89 & 14,81 & 28,30 & 21,19 \\
\hline 3 a 10 anos & 28,61 & 29,29 & 33,99 & 42,63 & 38,11 & 37,70 & 39,77 & 36,98 \\
\hline 11 a 29 anos & 10,93 & 12,96 & 10,32 & 26,27 & 19,47 & 21,33 & 12,42 & 20,14 \\
\hline 30 a 39 anos & 1,37 & 2,31 & 0,00 & 0,13 & 1,73 & 1,84 & 0,40 & 1,39 \\
\hline 40 anos ou mais & 0,34 & 0,00 & 1,64 & 0,00 & 0,00 & 0,00 & 0,42 & 0,00 \\
\hline \multicolumn{9}{|c|}{ Ext. de petróleo, gás nat.,carvão e outros comb. } \\
\hline $\begin{array}{l}\text { menos de } 1 \text { ano } \\
1 \text { a } 2 \text { anos }\end{array}$ & $\begin{array}{l}15,46 \\
10,00\end{array}$ & $\begin{array}{l}17,89 \\
11,19\end{array}$ & $\begin{array}{r}10,49 \\
7,43\end{array}$ & $\begin{array}{r}0,73 \\
23.28\end{array}$ & $\begin{array}{r}5,02 \\
19,05\end{array}$ & $\begin{array}{r}8,70 \\
12,77\end{array}$ & $\begin{array}{r}4,28 \\
11,24\end{array}$ & $\begin{array}{l}10,53 \\
13,83\end{array}$ \\
\hline 3 a 10 anos & 52,16 & 41,45 & 46,19 & 30,43 & 33,53 & 27,43 & 26,91 & 23,73 \\
\hline 11 a 29 anos & 20,67 & 26,24 & 35,89 & 45,24 & 42,40 & 50,22 & 57,57 & 51,90 \\
\hline 30 a 39 anos & 1,71 & 3,23 & 0,00 & 0,32 & 0,00 & 0,87 & 0,00 & 0,00 \\
\hline 40 anos ou mais & 0,00 & 0,00 & 0,00 & 0,00 & 0,00 & 0,00 & 0,00 & 0,00 \\
\hline \multicolumn{9}{|l|}{ Indústria } \\
\hline 1 a 2 anos & 23,27 & 27,68 & 24,41 & 19,27 & 25,66 & 26,06 & 26,26 & 24,44 \\
\hline 3 a 10 anos & 32,19 & 33,29 & 36,35 & 36,43 & 34,34 & 34,35 & 35,77 & 36,95 \\
\hline 11 a 29 anos & 14,59 & 12,96 & 15,00 & 17,77 & 15,24 & 14,75 & 15,41 & 15,14 \\
\hline 30 a 39 anos & 1,57 & 1,81 & 1,75 & 3,62 & 1,80 & 1,75 & 1,85 & 1,60 \\
\hline 40 anos ou mais & 0,93 & 0,94 & 0,77 & 1,01 & 1,11 & 0,91 & 1,02 & 0,85 \\
\hline \multicolumn{3}{|l|}{ Construção civil } & 31,51 & 33,19 & 31,89 & & & 25,65 \\
\hline 1 a 2 anos & 17,62 & 21,98 & 21,71 & 15,29 & 19,95 & 20,61 & 20,33 & 22,21 \\
\hline 3 a 10 anos & 24,86 & 25,00 & 29,24 & 29,62 & 28,43 & 29,48 & 28,83 & 31,78 \\
\hline 11 a 29 anos & 13,29 & 12,00 & 14,92 & 19,05 & 16,94 & 17,72 & 16,12 & 17,69 \\
\hline 30 a 39 anos & 1,32 & 1,61 & 1,94 & 1,46 & 2,22 & 2,23 & 2,23 & 2,16 \\
\hline 40 anos ou mais & 0,57 & 0,52 & 0,68 & 1,39 & 0,57 & 0,54 & 0,54 & 0,51 \\
\hline \multicolumn{9}{|c|}{ Serviços industriais de utilidade pública } \\
\hline menos de 1 ano & 9,37 & 10,91 & 6,62 & 8,03 & 10,82 & 13,13 & 12,81 & 11,63 \\
\hline 1 a 2 anos & 10,57 & 9,62 & 7,62 & 5,24 & 10,41 & 11,18 & 14,25 & 12,48 \\
\hline 3 a 10 anos & 36,06 & 34,37 & 35,36 & 24,51 & 28,45 & 25,37 & 26,49 & 30,77 \\
\hline 11 a 29 anos & 41,93 & 43,18 & 48,06 & 61,08 & 48,50 & 48,68 & 44,45 & 43,09 \\
\hline 30 a 39 anos & 1,77 & 1,93 & 2,19 & 1,14 & 1,64 & 1,65 & 1,95 & 2,02 \\
\hline 40 anos ou mais & 0,29 & 0,00 & 0,15 & 0,00 & 0,18 & 0,00 & 0,06 & 0,00 \\
\hline \multicolumn{9}{|l|}{ Serviços } \\
\hline menos de 1 ano & 25,49 & 22,55 & 22,26 & 22,19 & 20,96 & 19,52 & 18,77 & 18,97 \\
\hline 1 a 2 anos & 21,04 & 25,23 & 21,90 & 22,24 & 24,25 & 24,57 & 24,90 & 23,23 \\
\hline 3 a 10 anos & 35,56 & 35,80 & 36,32 & 33,83 & 35,75 & 36,28 & 37,33 & 37,92 \\
\hline 11 a 29 anos & 16,17 & 14,68 & 17,92 & 18,80 & 17,31 & 18,15 & 17,53 & 17,95 \\
\hline 30 a 39 anos & 1,28 & 1,30 & 1,35 & 2,21 & 1,42 & 1,10 & 1,13 & 1,49 \\
\hline 40 anos ou mais & 0,46 & 0,45 & 0,25 & 0,72 & 0,32 & 0,38 & 0,34 & 0,44 \\
\hline
\end{tabular}

Fonte: Dados da pesquisa. 
ANEXO O - Mão-de-obra ocupada nos macros setores por tempo de serviço (\%) - 1990/1999.

\begin{tabular}{|c|c|c|c|c|c|c|c|c|}
\hline & 1990 & 1992 & 1993 & 1995 & 1996 & 1997 & 1998 & 1999 \\
\hline & \multicolumn{8}{|c|}{ menos de 1 ano } \\
\hline Agropecuária & 24,35 & 18,22 & 18,30 & 23,42 & 11,46 & 17,66 & 17,18 & 17,81 \\
\hline Extrativa mineral (exc.combustíveis) & 0,73 & 0,58 & 0,65 & 0,24 & 0,34 & 0,45 & 0,34 & 0,33 \\
\hline Ext. de petróleo, gás nat.,carvão e outros combustíveis & 0,03 & 0,05 & 0,03 & 0,00 & 0,01 & 0,02 & 0,01 & 0,03 \\
\hline Indústria & 15,79 & 15,07 & 14,58 & 13,22 & 15,41 & 15,71 & 13,11 & 13,87 \\
\hline Serviços industrias de utilidade pública & 10,54 & 10,51 & 9,09 & 8,29 & 9,91 & 9,88 & 11,25 & 8,66 \\
\hline Construção civil & 0,19 & 0,25 & 0,17 & 0,15 & 0,22 & 0,28 & 0,27 & 0,22 \\
\hline Serviços & 48,36 & 55,33 & 57,19 & 54,67 & 62,64 & 56,00 & 57,85 & 59,08 \\
\hline \multirow[t]{2}{*}{ TOTAL } & 100,00 & 100,00 & 100,00 & 100,00 & 100,00 & 100,00 & 100,00 & 100,00 \\
\hline & \multicolumn{8}{|c|}{1 a 2 anos } \\
\hline Agropecuária & 19,14 & 20,84 & 21,17 & 15,91 & 14,54 & 16,79 & 18,37 & 17,15 \\
\hline Extrativa mineral (exc.combustíveis) & 0,54 & 0,51 & 0,52 & 0,33 & 0,35 & 0,24 & 0,41 & 0,30 \\
\hline Ext. de petróleo, gás nat.,carvão e outros combustíveis & 0,03 & 0,03 & 0,02 & 0,06 & 0,04 & 0,02 & 0,02 & 0,04 \\
\hline Indústria & 18,55 & 16,36 & 16,21 & 13,84 & 15,87 & 15,94 & 13,96 & 13,83 \\
\hline Serviços industrias de utilidade pública & 6,09 & 5,44 & 6,20 & 4,54 & 5,44 & 5,98 & 5,72 & 6,43 \\
\hline Construção civil & 0,30 & 0,20 & 0,19 & 0,12 & 0,19 & 0,20 & 0,24 & 0,20 \\
\hline Serviços & 55,35 & 56,63 & 55,68 & 65,20 & 63,58 & 60,83 & 61,29 & 62,06 \\
\hline \multirow[t]{2}{*}{ TOTAL } & 100,00 & 100,00 & 100,00 & 100,00 & 100,00 & 100,00 & 100,00 & 100,00 \\
\hline & \multicolumn{8}{|c|}{3 a 10 anos } \\
\hline Agropecuária & 25,36 & 27,24 & 26,51 & 24,81 & 27,11 & 24,77 & 21,56 & 21,20 \\
\hline Extrativa mineral (exc.combustíveis) & 0,43 & 0,37 & 0,43 & 0,47 & 0,36 & 0,38 & 0,38 & 0,31 \\
\hline Ext. de petróleo, gás nat.,carvão e outros combustíveis & 0,09 & 0,07 & 0,06 & 0,04 & 0,04 & 0,03 & 0,03 & 0,04 \\
\hline Indústria & 14,77 & 13,31 & 14,02 & 14,51 & 12,50 & 13,11 & 12,42 & 12,44 \\
\hline Serviços industrias de utilidade pública & 4,94 & 4,18 & 4,84 & 4,88 & 4,56 & 5,34 & 5,30 & 5,47 \\
\hline Construção civil & 0,59 & 0,48 & 0,52 & 0,30 & 0,30 & 0,29 & 0,29 & 0,29 \\
\hline Serviços & 53,82 & 54,35 & 53,62 & 54,98 & 55,13 & 56,08 & 60,03 & 60,25 \\
\hline \multirow[t]{2}{*}{ TOTAL } & 100,00 & 100,00 & 100,00 & 100,00 & 100,00 & 100,00 & 100,00 & 100,00 \\
\hline & \multicolumn{8}{|c|}{11 a 29 anos } \\
\hline Agropecuária & 31,29 & 37,99 & 34,80 & 23,68 & 31,54 & 30,53 & 28,08 & 33,73 \\
\hline Extrativa mineral (exc.combustíveis) & 0,33 & 0,34 & 0,24 & 0,53 & 0,35 & 0,39 & 0,23 & 0,30 \\
\hline Ext. de petróleo, gás nat.,carvão e outros combustíveis & 0,07 & 0,09 & 0,09 & 0,12 & 0,10 & 0,11 & 0,14 & 0,15 \\
\hline Indústria & 13,26 & 10,60 & 10,60 & 12,90 & 10,64 & 10,37 & 10,35 & 9,05 \\
\hline Serviços industrias de utilidade pública & 5,23 & 4,11 & 4,53 & 5,72 & 5,21 & 5,91 & 5,73 & 5,41 \\
\hline Construção civil & 1,36 & 1,25 & 1,29 & 1,36 & 0,98 & 1,03 & 0,93 & 0,73 \\
\hline Serviços & 48,47 & 45,63 & 48,45 & 55,68 & 51,18 & 51,67 & 54,54 & 50,64 \\
\hline \multirow[t]{2}{*}{ TOTAL } & 100,00 & 100,00 & 100,00 & 100,00 & 100,00 & 100,00 & 100,00 & 100,00 \\
\hline & \multicolumn{8}{|c|}{30 a 39 anos } \\
\hline Agropecuária & 47,70 & 53,68 & 47,87 & 63,16 & 52,83 & 57,18 & 46,21 & 43,76 \\
\hline Extrativa mineral (exc.combustíveis) & 0,37 & 0,45 & 0,00 & 0,01 & 0,24 & 0,28 & 0,07 & 0,20 \\
\hline Ext. de petróleo, gás nat.,carvão e outros combustíveis & 0,05 & 0,08 & 0,00 & 0,00 & 0,00 & 0,02 & 0,00 & 0,00 \\
\hline Indústria & 12,70 & 11,07 & 11,62 & 10,04 & 9,56 & 10,19 & 11,96 & 9,19 \\
\hline Serviços industrias de utilidade pública & 4,63 & 4,13 & 5,55 & 1,68 & 5,20 & 6,15 & 7,59 & 6,34 \\
\hline Construção civil & 0,51 & 0,42 & 0,56 & 0,10 & 0,25 & 0,29 & 0,39 & 0,33 \\
\hline Serviços & 34,04 & 30,18 & 34,40 & 25,01 & 31,92 & 25,89 & 33,78 & 40,18 \\
\hline \multirow[t]{2}{*}{ TOTAL } & 100,00 & 100,00 & 100,00 & 100,00 & 100,00 & 100,00 & 100,00 & 100,00 \\
\hline & \multicolumn{8}{|c|}{40 anos ou mais } \\
\hline Agropecuária & 43,50 & 49,93 & 66,21 & 48,35 & 62,78 & 63,51 & 48,89 & 53,37 \\
\hline Extrativa mineral (exc.combustíveis) & 0,23 & 0,00 & 0,86 & 0,00 & 0,00 & 0,00 & 0,20 & 0,00 \\
\hline Ext. de petróleo, gás nat.,carvão e outros combustíveis & 0,00 & 0,00 & 0,00 & 0,00 & 0,00 & 0,00 & 0,00 & 0,00 \\
\hline Indústria & 19,26 & 16,44 & 12,43 & 11,48 & 15,19 & 12,19 & 17,90 & 12,48 \\
\hline Serviços industrias de utilidade pública & 5,12 & 3,83 & 4,73 & 6,53 & 3,47 & 3,47 & 5,00 & 3,82 \\
\hline Construção civil & 0,21 & 0,00 & 0,10 & 0,00 & 0,07 & 0,00 & 0,03 & 0,00 \\
\hline Serviços & 31,66 & 29,80 & 15,67 & 33,65 & 18,49 & 20,83 & 27,98 & 30,33 \\
\hline TOTAL & 6,50 & 100,00 & 100,00 & 100,00 & 100,00 & 100,00 & 100,00 & 100,00 \\
\hline
\end{tabular}

Fonte: Dados da pesquisa. 
ANEXO P - Idade da mão-de-obra ocupada nos macro setores (\%) - 1990/1999.

\begin{tabular}{|c|c|c|c|c|c|c|c|c|}
\hline & 1990 & 1992 & 1993 & 1995 & 1996 & 1997 & 1998 & 1999 \\
\hline & \multicolumn{8}{|c|}{10 a 14 anos } \\
\hline Agropecuária & 38,58 & 51,42 & 43,48 & 30,43 & 51,48 & 43,17 & 51,37 & 57,81 \\
\hline Extrativa mineral (exc.combustíveis) & 0,46 & 0,82 & 0,90 & 0,05 & 0,31 & 0,31 & 0,52 & 0,22 \\
\hline Ext. de petróleo, gás nat.,carvão e outros combustíveis & 0,00 & 0,00 & 0,03 & 0,00 & 0,00 & 0,00 & 0,00 & 0,00 \\
\hline Indústria & 13,85 & 9,95 & 10,64 & 11,13 & 9,81 & 8,87 & 7,81 & 7,03 \\
\hline Serviços industrias de utilidade pública & 4,03 & 2,14 & 2,65 & 6,48 & 2,81 & 2,10 & 2,08 & 2,41 \\
\hline Construção civil & 0,01 & 0,00 & 0,01 & 0,00 & 0,01 & 0,05 & 0,03 & 0,09 \\
\hline Serviços & 43,07 & 35,67 & 42,30 & 51,91 & 35,57 & 45,49 & 38,20 & 32,44 \\
\hline \multirow[t]{2}{*}{ TOTAL } & 100,00 & 100,00 & 100,00 & 100,00 & 100,00 & 100,00 & 100,00 & 100,00 \\
\hline & \multicolumn{8}{|c|}{15 a 19 anos } \\
\hline Agropecuária & 30,94 & 30,13 & 33,04 & 43,78 & 27,17 & 30,44 & 30,93 & 32,96 \\
\hline Extrativa mineral (exc.combustíveis) & 0,59 & 0,35 & 0,45 & 0,08 & 0,53 & 0,37 & 0,40 & 0,47 \\
\hline Ext. de petróleo, gás nat.,carvão e outros combustíveis & 0,03 & 0,04 & 0,01 & 0,00 & 0,00 & 0,00 & 0,01 & 0,01 \\
\hline Indústria & 17,37 & 15,44 & 14,11 & 10,99 & 15,52 & 14,40 & 13,10 & 13,94 \\
\hline Serviços industrias de utilidade pública & 6,56 & 6,13 & 6,38 & 4,66 & 6,11 & 5,62 & 6,61 & 5,99 \\
\hline Construção civil & 0,14 & 0,17 & 0,13 & 0,27 & 0,23 & 0,21 & 0,21 & 0,17 \\
\hline Serviços & 44,37 & 47,76 & 45,87 & 40,21 & 50,43 & 48,97 & 48,74 & 46,46 \\
\hline \multirow[t]{2}{*}{ TOTAL } & 100,00 & 100,00 & 100,00 & 100,00 & 100,00 & 100,00 & 100,00 & 100,00 \\
\hline & \multicolumn{8}{|c|}{20 a 29 anos } \\
\hline Agropecuária & 25,39 & 22,30 & 23,36 & 23,58 & 22,81 & 20,80 & 20,51 & 21,20 \\
\hline Extrativa mineral (exc.combustíveis) & 0,63 & 0,39 & 0,66 & 0,23 & 0,32 & 0,35 & 0,42 & 0,31 \\
\hline Ext. de petróleo, gás nat.,carvão e outros combustíveis & 0,08 & 0,05 & 0,03 & 0,05 & 0,02 & 0,02 & 0,01 & 0,04 \\
\hline Indústria & 16,60 & 16,13 & 15,14 & 13,93 & 14,60 & 14,95 & 14,50 & 14,68 \\
\hline Serviços industrias de utilidade pública & 6,61 & 6,32 & 5,90 & 5,06 & 5,78 & 6,41 & 6,90 & 6,55 \\
\hline Construção civil & 0,46 & 0,36 & 0,34 & 0,11 & 0,27 & 0,25 & 0,29 & 0,23 \\
\hline Serviços & 50,23 & 54,45 & 54,57 & 57,04 & 56,21 & 57,22 & 57,36 & 56,98 \\
\hline \multirow[t]{2}{*}{ TOTAL } & 100,00 & 100,00 & 100,00 & 100,00 & 100,00 & 100,00 & 100,00 & 100,00 \\
\hline & \multicolumn{8}{|c|}{30 a 39 anos } \\
\hline Agropecuária & 24,09 & 24,10 & 22,77 & 19,38 & 20,52 & 20,27 & 18,80 & 19,38 \\
\hline Extrativa mineral (exc.combustíveis) & 0,44 & 0,47 & 0,26 & 0,82 & 0,39 & 0,33 & 0,28 & 0,28 \\
\hline Ext. de petróleo, gás nat.,carvão e outros combustíveis & 0,07 & 0,08 & 0,10 & 0,11 & 0,09 & 0,08 & 0,06 & 0,07 \\
\hline Indústria & 15,52 & 13,57 & 14,40 & 13,44 & 13,40 & 12,65 & 12,75 & 12,03 \\
\hline Serviços industrias de utilidade pública & 6,87 & 6,11 & 5,94 & 6,16 & 5,96 & 6,25 & 6,61 & 6,38 \\
\hline Construção civil & 0,74 & 0,76 & 0,74 & 0,40 & 0,46 & 0,43 & 0,48 & 0,38 \\
\hline Serviços & 52,28 & 54,91 & 55,78 & 59,69 & 59,19 & 60,00 & 61,03 & 61,49 \\
\hline \multirow[t]{2}{*}{ TOTAL } & 100,00 & 100,00 & 100,00 & 100,00 & 100,00 & 100,00 & 100,00 & 100,00 \\
\hline & \multicolumn{8}{|c|}{40 a 49 anos } \\
\hline Agropecuária & 22,11 & 26,38 & 28,46 & 20,70 & 21,17 & 20,59 & 18,73 & 20,72 \\
\hline Extrativa mineral (exc.combustíveis) & 0,42 & 0,39 & 0,36 & 0,28 & 0,21 & 0,35 & 0,30 & 0,27 \\
\hline Ext. de petróleo, gás nat.,carvão e outros combustíveis & 0,05 & 0,08 & 0,06 & 0,05 & 0,06 & 0,06 & 0,10 & 0,13 \\
\hline Indústria & 14,35 & 12,54 & 12,79 & 15,75 & 12,59 & 12,43 & 11,73 & 11,52 \\
\hline Serviços industrias de utilidade pública & 7,10 & 5,51 & 5,93 & 5,81 & 5,87 & 6,35 & 6,79 & 6,50 \\
\hline Construção civil & 0,85 & 0,65 & 0,81 & 1,15 & 0,65 & 0,66 & 0,58 & 0,58 \\
\hline Serviços & 55,12 & 54,45 & 51,59 & 56,27 & 59,45 & 59,56 & 61,77 & 60,29 \\
\hline \multirow[t]{2}{*}{ TOTAL } & 100,00 & 100,00 & 100,00 & 100,00 & 100,00 & 100,00 & 100,00 & 100,00 \\
\hline & \multicolumn{8}{|c|}{50 anos ou mais } \\
\hline Agropecuária & 24,90 & 26,55 & 24,97 & 26,04 & 24,32 & 24,71 & 22,70 & 23,75 \\
\hline Extrativa mineral (exc.combustíveis) & 0,48 & 0,51 & 0,37 & 0,31 & 0,39 & 0,33 & 0,30 & 0,31 \\
\hline Ext. de petróleo, gás nat.,carvão e outros combustíveis & 0,05 & 0,03 & 0,01 & 0,01 & 0,03 & 0,03 & 0,02 & 0,02 \\
\hline Indústria & 13,33 & 11,95 & 12,19 & 12,51 & 11,38 & 10,61 & 10,50 & 9,56 \\
\hline Serviços industrias de utilidade pública & 6,92 & 5,79 & 6,56 & 5,87 & 6,50 & 6,43 & 6,96 & 6,09 \\
\hline Construção civil & 0,48 & 0,54 & 0,59 & 0,21 & 0,27 & 0,37 & 0,33 & 0,31 \\
\hline Serviços & 53,85 & 54,62 & 55,31 & 55,04 & 57,11 & 57,53 & 59,18 & 59,97 \\
\hline TOTAL & 100,00 & 100,00 & 100,00 & 100,00 & 100,00 & 100,00 & 100,00 & 100,00 \\
\hline
\end{tabular}

Fonte: Dados da pesquisa. 
ANEXO Q - Idade da mão-de-obra ocupada por macro setores (\%) - 1990/1999.

\begin{tabular}{|c|c|c|c|c|c|c|c|c|}
\hline & 1990 & 1992 & 1993 & 1995 & 1996 & 1997 & 1998 & 1999 \\
\hline \multicolumn{9}{|l|}{ Agropecuária } \\
\hline 10 a 14 anos & 4,53 & 9,52 & 5,23 & 2,54 & 6,09 & 5,50 & 6,69 & 6,70 \\
\hline 15 a 19 anos & 13,94 & 13,50 & 14,12 & 19,20 & 11,21 & 13,13 & 13,44 & 12,48 \\
\hline 20 a 29 anos & 29,12 & 23,70 & 25,14 & 24,67 & 25,68 & 23,82 & 24,13 & 23,38 \\
\hline 30 a 39 anos & 25,01 & 21,11 & 22,00 & 18,93 & 24,04 & 24,42 & 23,04 & 22,91 \\
\hline 40 a 49 anos & 14,82 & 18,07 & 20,88 & 16,33 & 18,45 & 17,97 & 17,59 & 18,29 \\
\hline 50 anos ou mais & 12,58 & 14,10 & 12,63 & 18,33 & 14,53 & 15,16 & 15,11 & 16,24 \\
\hline \multicolumn{9}{|c|}{ Extrativa mineral (exceto combustíveis) } \\
\hline 10 a 14 anos & 2,65 & 9,10 & 6,28 & 0,28 & 2,48 & 2,66 & 4,32 & 1,96 \\
\hline 15 a 19 anos & 13,09 & 9,30 & 11,20 & 2,36 & 14,76 & 10,52 & 11,24 & 13,40 \\
\hline 20 a 29 anos & 35,82 & 24,56 & 41,43 & 15,71 & 24,09 & 26,73 & 31,79 & 25,93 \\
\hline 30 a 39 anos & 22,53 & 24,47 & 14,83 & 52,98 & 30,61 & 26,27 & 21,64 & 24,84 \\
\hline 40 a 49 anos & 13,99 & 16,21 & 15,32 & 14,39 & 12,36 & 20,32 & 18,13 & 17,80 \\
\hline 50 anos ou mais & 11,91 & 16,36 & 10,95 & 14,28 & 15,70 & 13,50 & 12,88 & 16,06 \\
\hline \multicolumn{9}{|c|}{ Ext. de petróleo, gás nat.,carvão e outros comb. } \\
\hline 10 a 14 anos & 0,00 & 0,00 & 1,90 & 0,00 & 0,00 & 0,00 & 0,00 & 0,00 \\
\hline 15 a 19 anos & 6,54 & 8,50 & 1,77 & 0,11 & 0,00 & 0,00 & 1,24 & 1,36 \\
\hline 20 a 29 anos & 37,73 & 25,56 & 18,49 & 24,37 & 9,70 & 10,67 & 6,46 & 17,43 \\
\hline 30 a 39 anos & 31,20 & 32,52 & 50,64 & 54,44 & 53,23 & 52,86 & 38,92 & 32,63 \\
\hline 40 a 49 anos & 14,40 & 26,51 & 23,42 & 18,74 & 28,57 & 26,55 & 46,46 & 43,94 \\
\hline 50 anos ou mais & 10,12 & 6,90 & 3,79 & 2,34 & 8,51 & 9,92 & 6,91 & 4,63 \\
\hline \multicolumn{9}{|l|}{ Indústria } \\
\hline 10 a 14 anos & 2,67 & 3,49 & 2,41 & 1,70 & 2,02 & 1,98 & 1,77 & 1,53 \\
\hline 15 a 19 anos & 12,84 & 13,12 & 11,37 & 8,82 & 11,14 & 10,88 & 9,91 & 9,92 \\
\hline 20 a 29 anos & 31,22 & 32,51 & 30,70 & 26,66 & 28,61 & 30,01 & 29,72 & 30,43 \\
\hline 30 a 39 anos & 26,44 & 22,55 & 26,22 & 24,00 & 27,32 & 26,71 & 27,22 & 26,72 \\
\hline 40 a 49 anos & 15,78 & 16,29 & 17,68 & 22,72 & 19,09 & 19,01 & 19,19 & 19,11 \\
\hline 50 anos ou mais & 11,05 & 12,04 & 11,62 & 16,11 & 11,82 & 11,41 & 12,18 & 12,28 \\
\hline \multicolumn{9}{|l|}{ Construção civil } \\
\hline 10 a 14 anos & 1,80 & 1,80 & 1,40 & 2,39 & 1,31 & 0,99 & 0,89 & 1,03 \\
\hline 15 a 19 anos & 11,20 & 12,45 & 11,97 & 9,04 & 9,95 & 8,97 & 9,46 & 8,34 \\
\hline 20 a 29 anos & 28,73 & 30,45 & 27,85 & 23,40 & 25,67 & 27,14 & 26,74 & 26,54 \\
\hline 30 a 39 anos & 27,01 & 24,26 & 25,15 & 26,61 & 27,55 & 27,85 & 26,66 & 27,71 \\
\hline 40 a 49 anos & 18,02 & 17,10 & 19,08 & 20,27 & 20,18 & 20,48 & 20,99 & 21,09 \\
\hline 50 anos ou mais & 13,24 & 13,94 & 14,55 & 18,28 & 15,32 & 14,57 & 15,25 & 15,29 \\
\hline \multicolumn{9}{|c|}{ Serviços industriais de utilidade pública } \\
\hline 10 a 14 anos & 0,06 & 0,00 & 0,04 & 0,01 & 0,09 & 0,39 & 0,19 & 0,69 \\
\hline 15 a 19 anos & 2,81 & 4,00 & 2,80 & 7,07 & 5,77 & 5,34 & 5,08 & 4,26 \\
\hline 20 a 29 anos & 24,21 & 20,82 & 17,93 & 7,07 & 18,10 & 17,05 & 19,27 & 17,26 \\
\hline 30 a 39 anos & 35,43 & 35,73 & 35,36 & 23,00 & 32,38 & 30,43 & 32,55 & 29,82 \\
\hline 40 a 49 anos & 26,36 & 23,94 & 29,22 & 53,87 & 33,98 & 33,66 & 30,66 & 33,90 \\
\hline 50 anos ou mais & 11,13 & 15,51 & 14,65 & 8,96 & 9,67 & 13,13 & 12,24 & 14,07 \\
\hline \multicolumn{9}{|l|}{ Serviços } \\
\hline 10 a 14 anos & 2,52 & 3,30 & 2,50 & 1,94 & 1,73 & 2,30 & 1,87 & 1,50 \\
\hline 15 a 19 anos & 9,94 & 10,69 & 9,65 & 7,91 & 8,54 & 8,38 & 7,97 & 7,01 \\
\hline 20 a 29 anos & 28,65 & 28,89 & 28,91 & 26,75 & 25,99 & 26,01 & 25,39 & 25,03 \\
\hline 30 a 39 anos & 27,00 & 24,02 & 26,53 & 26,14 & 28,47 & 28,69 & 28,14 & 28,95 \\
\hline 40 a 49 anos & 18,37 & 18,62 & 18,63 & 19,90 & 21,27 & 20,62 & 21,82 & 21,19 \\
\hline 50 anos ou mais & 13,53 & 14,49 & 13,77 & 17,37 & 14,00 & 14,00 & 14,81 & 16,33 \\
\hline
\end{tabular}

Fonte: Dados da pesquisa. 
ANEXO R - Número de pessoas ocupadas por anos de estudo - 1990/1992.

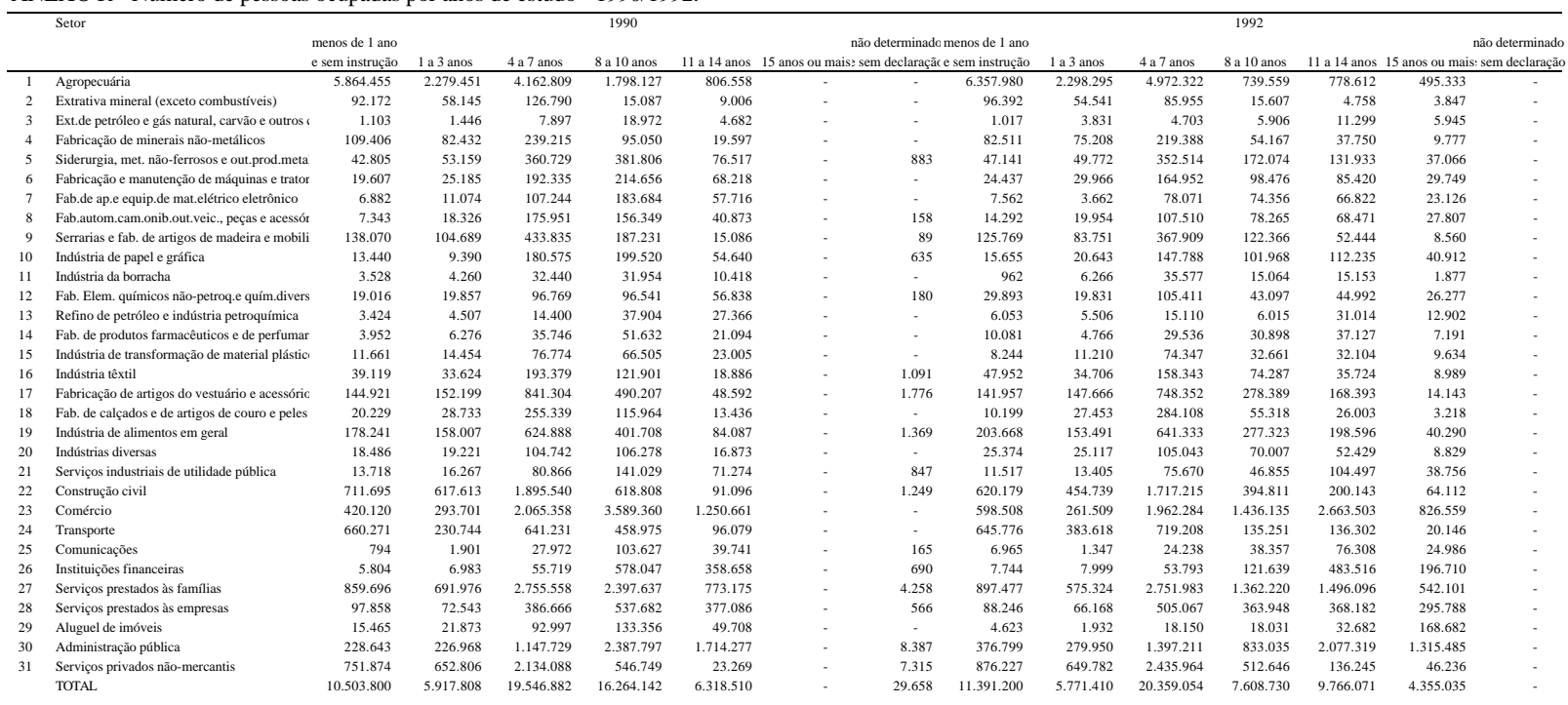


ANEXO R - Número de pessoas ocupadas por anos de estudo - 1993/1995.

\begin{tabular}{|c|c|c|c|c|c|c|c|c|c|c|c|c|c|}
\hline & Setor & & & & 1993 & & & & & & 1995 & & \\
\hline & & & & & & & & & & & & & \\
\hline & Agropecuária & $\frac{1}{4.563 .385}$ & $\frac{1932505}{2.82 .711}$ & 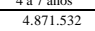 & 956.682 & 1.221 .588 & 1.1.132.701 & & & & & & 1.008. \\
\hline & al (excetoc & & & & & & & & & & & & \\
\hline & 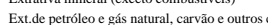 & ${ }_{1.322}$ & & ${ }_{4.336}$ & 2.2033 & 年14.362 & 6.600 & . & & 3.353 & 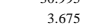 & ${ }_{9.541}$ & $\begin{array}{l}28.773 \\
13.609\end{array}$ \\
\hline & Fabricą̧ăo de minerais nâo-metálicos & 57.047 & 49.587 & 220.442 & 65.313 & 56.552 & 19.960 & 92.511 & 27.678 & 150.273 & 46.702 & 75.924 & 50.811 \\
\hline & Siderurgia, , net. nä-ferrososos cout.prod.meta & 27.014 & 34.951 & 288.771 & 179.700 & 180.242 & 47.622 & 13.900 & 46.156 & & 193.719 & 159.781 & 150.029 \\
\hline & 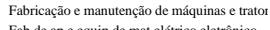 & 10.065 & $\begin{array}{c}19.413 \\
5398\end{array}$ & 162.983 & 92.019 & 88.573 & 41.547 & 3.306 & 4.702 & 76.337 & 87.115 & 151.171 & 99.169 \\
\hline & 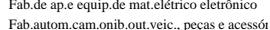 & $\begin{array}{l}3.1 .16 \\
8.128\end{array}$ & $\begin{array}{l}5.398 \\
7.951 \\
7\end{array}$ & 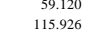 & $\begin{array}{l}69.445 \\
84410\end{array}$ & 78.6601 & 29.399 & $\begin{array}{l}17.412 \\
1.1872\end{array}$ & $\begin{array}{r}658 \\
2.377\end{array}$ & $\begin{array}{l}58.563 \\
70.127\end{array}$ & $\begin{array}{l}67.396 \\
81386\end{array}$ & 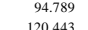 & 37.382 \\
\hline & 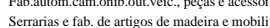 & $\begin{array}{r}8.128 \\
86.499\end{array}$ & 1.931 & $\begin{array}{l}715.966 \\
387.181\end{array}$ & 84.410 & 76.046 & $\begin{array}{l}30.399 \\
14.515\end{array}$ & 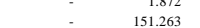 & 55.826 & 344.563 & $\begin{aligned} 81.386 \\
150.316\end{aligned}$ & 120.443 & $\begin{array}{l}47.795 \\
19.891\end{array}$ \\
\hline & Industriact & 12.747 & 8.589 & 102.692 & 109.450 & 124.640 & 50.582 & 2.221 & 年 & 57.589 & 85.396 & ${ }_{162.932}$ & $\begin{array}{l}199.891 \\
123.891\end{array}$ \\
\hline & Indústria da borracha & 2.001 & 3.373 & 25.619 & 19.725 & 19.820 & 1.463 & 1.442 & 1.497 & 14.869 & 10.597 & 31.022 & 7.472 \\
\hline & ñäo-petroq.e quím.divers & 10.291 & 8.409 & 84.454 & 39.149 & 52 & 34.145 & 11.338 & 11.725 & 62.980 & 18.121 & 61.103 & 71.133 \\
\hline & troquímica & 846 & 2.015 & 14.962 & 8.198 & 35.101 & 15.778 & 356 & 63 & 12.169 & 2.396 & 7.225 & 45.392 \\
\hline $\begin{array}{l}14 \\
15\end{array}$ & 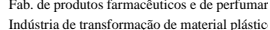 & $\begin{array}{l}2.046 \\
6190\end{array}$ & $\begin{array}{l}4.992 \\
7.648\end{array}$ & $\begin{array}{l}32.090 \\
70.279 \\
70.025\end{array}$ & $\begin{array}{l}23,393 \\
42997 \\
4\end{array}$ & 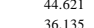 & $\begin{array}{l}18.958 \\
7751 \\
751\end{array} \mathrm{l}$ & 94 & 2537 & $\begin{array}{l}32.816 \\
51416\end{array}$ & 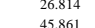 & $\begin{array}{l}23.433 \\
51201\end{array}$ & $\begin{array}{l}44.807 \\
11.991\end{array}$ \\
\hline 16 & 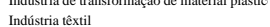 & $\begin{array}{r}6.1900 \\
21.493\end{array}$ & 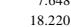 & 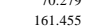 & 86.235 & 54.870 & $\begin{array}{r}7.751 \\
13.628 \\
-\end{array}$ & & $\begin{array}{l}2.2779 \\
22.746\end{array}$ & $\begin{aligned} \begin{array}{r}51.416 \\
123.856\end{array} & -3\end{aligned}$ & $\begin{array}{l}45.861 \\
45.725\end{array}$ & $\begin{array}{l}51.291 \\
60.252\end{array}$ & $\begin{array}{l}1.1991 \\
32.958\end{array}$ \\
\hline & Fabricąăó de ar & & 104.219 & 732.993 & 342.213 & 263.883 & 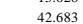 & 102.831 & 119.106 & 686.951 & 411.257 & 229.656 & $\begin{array}{l}3.2588 \\
94.299\end{array}$ \\
\hline 18 & Fab. de callados e de artigos de couro e peles & 13.255 & 25.249 & 235.433 & 92.492 & 51.025 & 10.646 & 3.286 & 8.289 & 131.932 & 43.638 & 128.879 & 44.475 \\
\hline & Ind & 102.330 & & & & & & & 45.920 & 527.142 & 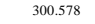 & 408.677 & 164.108 \\
\hline & $\begin{array}{l}\text { Indústrtias d } \\
\text { Servicosing }\end{array}$ & 12.029 & & & $\begin{array}{l}75.918 \\
58710\end{array}$ & & & & 18.123 & & 52.179 & & 37.724 \\
\hline & de utilidade pública & $\begin{aligned} 111.1999 \\
484898\end{aligned}$ & & $\begin{array}{r}65.0 .082 \\
1.756 .678\end{array}$ & $\begin{array}{r}58.79 \\
482.035 \\
-1950\end{array}$ & $\begin{array}{l}115.666 \\
272487\end{array}$ & & $\begin{array}{r}11.840 \\
418699\end{array}$ & $\begin{aligned} 1.046 \\
471634\end{aligned}$ & 493 & $\begin{aligned} 34.359 \\
2802060\end{aligned}$ & $\begin{aligned} 83.650 \\
3.52700 \\
3\end{aligned}$ & $\begin{array}{r}90.160 \\
404560\end{array}$ \\
\hline 23 & 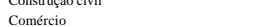 & $\begin{array}{l}484.888 \\
416.806\end{array}$ & 200.591 & 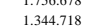 & $\begin{array}{l}1.42 .38 .39 \\
1.340\end{array}$ & $\begin{array}{l}2.22 .487 \\
3.43 .848\end{array}$ & 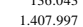 & ${ }_{21.638}^{41.639}$ & ${ }_{34.062}^{4}-064$ & $\begin{array}{l}1.424 .193 \\
1.067 .884\end{array}$ & 933.710 & 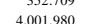 & $\begin{array}{l}45.4560 \\
2.81 .426\end{array}$ \\
\hline & Transporte & 438.135 & 359.304 & 712.516 & 225.218 & 242.126 & 87.601 & 295.196 & 158.096 & 1.105 .562 & 160.468 & 453 & ${ }_{921.136} 1.136$ \\
\hline 25 & Comunic & 1.293 & 1.521 & 17.396 & 26.919 & 14 & 34.657 & 6.909 & 407 & 11.244 & 13.880 & 116 & 33.943 \\
\hline & Insitit & 5.6 & 2.997 & 24 & & & & 901 & 656 & & 39.979 & 409.462 & 298.959 \\
\hline & Serviços prestados às $\mathrm{f}$ & 501.334 & 422.031 & 2.363 .401 & 1.4444.998 & 1.897 .878 & 58 & 260.085 & 308.146 & 1.695.968 & 1.497.922 & 2.824.373 & .076.105 \\
\hline & $\begin{array}{l}\text { Servicos } \mathrm{p} \\
\text { Aluneld }\end{array}$ & $\begin{array}{l}61.910 \\
7255\end{array}$ & $\begin{array}{ll}41.560 \\
6694\end{array}$ & 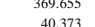 & $\begin{array}{l}310.620 \\
49333\end{array}$ & $\begin{array}{l}448.754 \\
86280\end{array}$ & 466.253 & 6.226 & $\begin{array}{l}21.824 \\
413\end{array}$ & 220.593 & 要9.525 & & 124.786 \\
\hline & $\begin{array}{l}\text { Alagu } \\
\text { Admin }\end{array}$ & 053 & 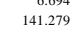 & 924.3861 & 676.127 & $\begin{array}{l}8.124 .280 \\
-2.003\end{array}$ & 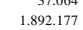 & $\begin{array}{l}13.691 \\
134.464\end{array}$ & 117.673 & & 600.675 & 1.517 .580 & 363.737 \\
\hline & & & 584.701 & 2.551 .133 & 668.322 & 216.441 & 80.663 & 881.752 & 798.920 & 54.823 & 620.210 & 328. & 122. \\
\hline & & 71.760 & 25.317 & 18.610.587 & 8.301.068 & 312.432 & .909.135 & 8.868951 & 647.863 & .2.74.432 & 848.887 & 892.082 & .693.884 \\
\hline
\end{tabular}


ANEXO R - Número de pessoas ocupadas por anos de estudo - 1996 - 1997.

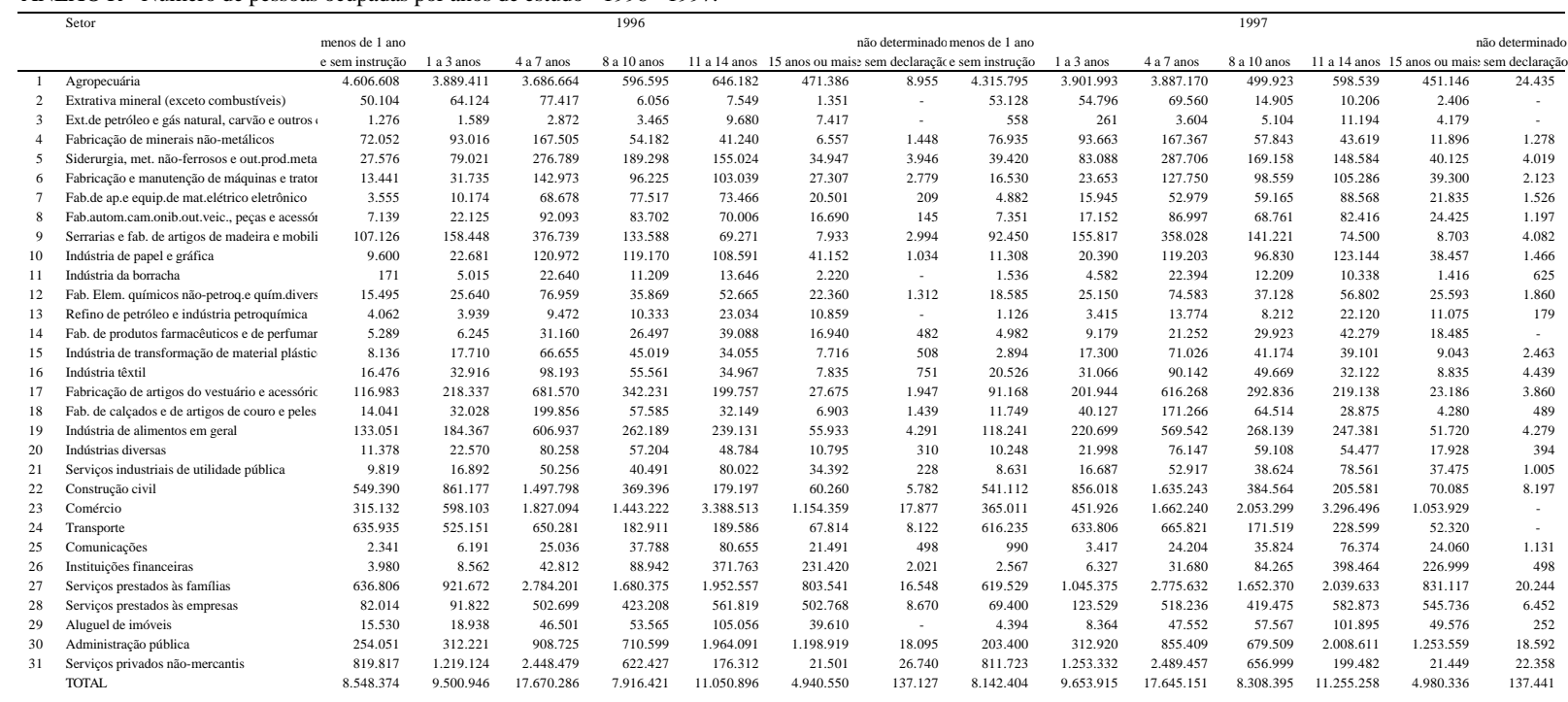




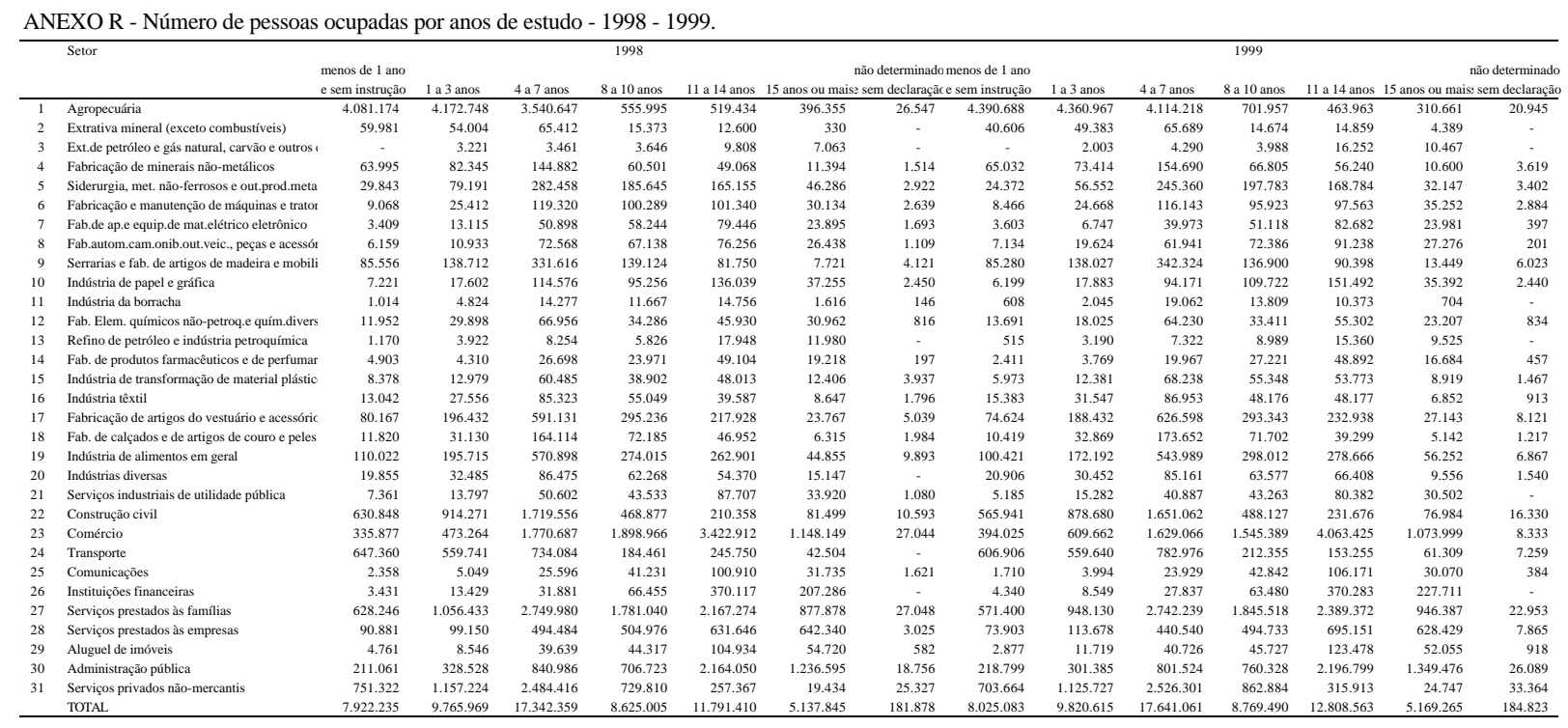


ANEXO S - Pessoal ocupado por gênero em cada setor - 1991 - 1999.

\begin{tabular}{|c|c|c|c|c|c|c|c|c|c|c|c|c|c|c|c|c|}
\hline & & & & & lino & & & & alino & & allino & & Uino & & & \\
\hline 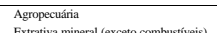 & & & & & & & 62.088 & & 2.387 .992 & $\lim$ & 1.455278 & $\frac{\pi}{1.733 .7}$ & 1337301 & & & \\
\hline $\begin{array}{l}\text { tiva mineral lexcetoto comb } \\
\text { e pertroleo gas natural. }\end{array}$ & & 23.408 & & & & & $\begin{array}{l}.786 \\
5515\end{array}$ & 4.514 & & 14.117 & 188.764 & 16.236 & 1899941 & 17.759 & 177.018 & \\
\hline . & & $\begin{array}{l}50.057 \\
50.57\end{array}$ & 428.051 & $\begin{array}{l}3.3878 \\
50749\end{array}$ & 395.667 & $\begin{array}{l}3996 \\
73233 \\
733\end{array}$ & 39.876 & 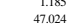 & 393.404 & $\begin{aligned} 3.107 \\
42.596\end{aligned}$ & & & 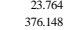 & $\begin{array}{l}3.366 \\
37.552\end{array}$ & & 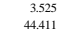 \\
\hline ial met. nâa-fe & & & & & & & & & & 79396 & & & & & & 78.349 \\
\hline 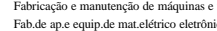 & 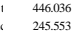 & 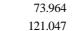 & 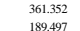 & $\begin{array}{l}71.648 \\
6.103 \\
6.103\end{array}$ & $\begin{array}{l}342995 \\
174461\end{array}$ & 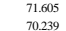 & $\begin{array}{l}327.798 \\
187290\end{array}-20$ & $\begin{array}{l}94.092 \\
88910\end{array}$ & $\begin{array}{l}345.704 \\
155922\end{array}$ & $\begin{array}{l}7.796 \\
6.178 \\
-1750\end{array}$ & $\begin{array}{l}342.143 \\
174487\end{array}-10$ & $\begin{array}{l}7.1097 \\
70413\end{array}$ & 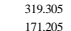 & 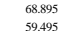 & $\begin{array}{l}317.34 \\
156633\end{array}$ & 65.3566 650 \\
\hline 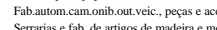 & 3480.066 & 50.934 & 273.248 & 152 & 2857.703 & 37.297 & 27.933 & 52.067 & 255.270 & 36.630 & 242.732 & 45.568 & 299.474 & 31.126 & 241.597 & 38203 \\
\hline ase fab. de antig & 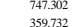 & $\begin{array}{l}131.698 \\
94868\end{array}$ & & & 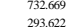 & & & 68.169 & & $\begin{array}{l}877933 \\
1117036 \\
-10\end{array}$ & 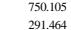 & & $\begin{array}{l}709303 \\
203919 \\
2019\end{array}$ & 792977 & $\begin{array}{l}741.233 \\
304362\end{array}$ & 71.1167 \\
\hline 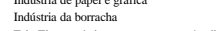 & & & (337.433 & & & & & & & 58 & & & 95 & 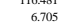 & . & 8.024 \\
\hline Elem. quimicos nâ-pertrqq.e quím.ji & 2355 & 53.664 & 220.152 & 49.348 & 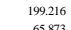 & 47.784 & 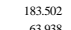 & 52898 & 52366 & 46.171 & 214 & 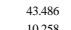 & $\begin{array}{l}183.138 \\
43585\end{array}$ & $\begin{array}{l}37.662 \\
5.515\end{array}$ & $\begin{array}{l}1772.264 \\
36097\end{array}$ & $\begin{array}{l}3.4 .36 \\
8083\end{array}$ \\
\hline de produtus famaceutiticos e de perft & 72539 & 46.161 & 等.1.195 & $\begin{array}{l}151414 \\
46,05\end{array}$ & 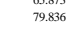 & 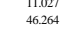 & 99.473 & 37.027 & & 9 & & & $\begin{array}{lll}85 \\
015\end{array}$ & 699 & 71.1174 & $48.226 \mathrm{Y}$ \\
\hline tria de & 134.667 & 364 & 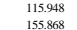 & 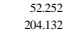 & 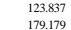 & ${ }_{21}^{63}$ & $\begin{array}{ll}131.471 \\
16744\end{array}$ & 33.429 & 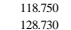 & 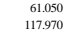 & 359 & 56641 & 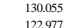 & 50.5045 & 146.292 & 59.8082 \\
\hline iod atr & & 1.50.503 20.50 & & & 691 & & & & & & & & & $4+2$ & 453 & \\
\hline de calalados e de artigos de couro e & & 178.620 & 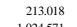 & 1932282 & 20.0010 & 1982822 & . & 100.80 & & 年 & & 10 & 189.302 & 年 & 10.09080 & 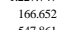 \\
\hline $\begin{array}{l}\text { arate a almen } \\
\text { ais diveras }\end{array}$ & & & & & & & & & & & & & & & & .861 \\
\hline industrais $\mathrm{c}$ & & 39.050 & & & & & & 12 & & 35907 & & 85 & & 40.092 & & 739 \\
\hline ç̆ono ci & & & & & & & & & & & & & & & & \\
\hline & & 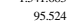 & & - & & 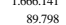 & & 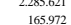 & 382 & 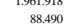 & & 年 & (6076 & 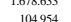 & & .419 \\
\hline & & & 114,496 & & & & & & & 55 & & & & & & 60.704 \\
\hline Ins & & & & & & & & & & & & & & & & \\
\hline 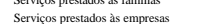 & & 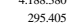 & & 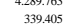 & & & & 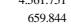 & & 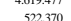 & & & & 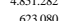 & & 999.683 \\
\hline 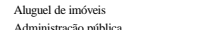 & 1420209 & $\begin{array}{r}78.704 \\
0.0351\end{array}$ & $\begin{array}{l}1592204 \\
1.5655646\end{array}$ & 84.996 & 156231 & $\begin{array}{r}70.969 \\
4203772\end{array}$ & $\begin{array}{l}198.15 \\
1.50238 \\
\end{array}$ & $\begin{aligned} 887785 \\
37607272\end{aligned}$ & $\begin{array}{l}177.877 \\
143765\end{array}$ & $\begin{array}{r}10.1323 \\
{ }_{302095}\end{array}$ & 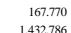 & 1.830 & 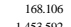 & 89.394 & 173.452 & $\begin{array}{l}104048 \\
10613\end{array}$ \\
\hline & & & 3369618 & 4.320 .182 & 324.051 & 749 & 5.515 & (285 & & (1939.746 & 2883 & 20.517 & 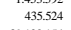 & 0.999 .376 & 441.1 & \\
\hline & & & & & & & & & & & & & & 1.544 & & \\
\hline
\end{tabular}


ANEXO T- Número de pessoas ocupadas por idade em cada setor - 1990/1992.

\begin{tabular}{|c|c|c|c|c|c|c|c|c|c|c|c|c|c|}
\hline & \multirow{2}{*}{ Setor } & \multirow{2}{*}{\multicolumn{6}{|c|}{$\begin{array}{cccc}10 \mathrm{a} 14 & 1990 \\
\text { anos } & 15 \mathrm{a} 19 \text { anos } & 20 \mathrm{a} 29 \text { anos } \quad 30 \mathrm{a} 39 \text { anos } \quad 40 \mathrm{a} 49 \text { anos } 50 \text { anos ou mais }\end{array}$}} & \multicolumn{6}{|c|}{1992} \\
\hline & & & & & & & & 10 a 14 anos & 15 a 19 anos & 20 a 29 anos & 30 a $39 \mathrm{ar}$ & 40 a 49 & \\
\hline 1 & Agropecuária & 676.229 & 2.078 .540 & 4.342 .715 & 3.729 .395 & 2.209 .391 & 1.875 .130 & 1.488 .747 & 2.112 .311 & 3.706 .725 & 3.301 .992 & 2.826 .250 & 2.206 .075 \\
\hline 2 & Extrativa mineral (exc & 7.996 & 39.442 & 107.888 & 67.870 & 42.134 & 35.870 & 23.751 & 24.287 & 64.138 & 63.878 & 42.320 & 42.726 \\
\hline & Ext.de petróleo e gás nà & & 2.230 & 12.867 & 10.640 & 12 & 51 & & 80 & 8.358 & 10.633 & 70 & 258 \\
\hline 4 & Fabricação & 34.684 & 104.365 & 154.694 & 127.622 & 75.156 & 49.177 & 885 & 85.566 & 164.062 & 101.273 & 62.901 & 39.013 \\
\hline & Siderurgia, met. não-ferrosos e c & 11.986 & 95.532 & 294.009 & 281.024 & 152.774 & 80.576 & 10.088 & 103.547 & 257.135 & 195.108 & 155.186 & 69.435 \\
\hline 6 & 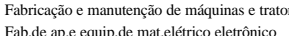 & 2.833 & 56.089 & 167.858 & 159.212 & 86.355 & 47.654 & 8.251 & $\begin{array}{l}41.432 \\
3.3194\end{array}$ & 160.290 & 4.282 & 85.202 & 43.544 \\
\hline 8 & 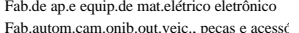 & 2.692 & $\begin{array}{l}41.302 \\
27.035\end{array}$ & 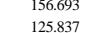 & $\begin{array}{l}104946 \\
139.222\end{array}$ & 76.843 & $\begin{array}{l}14.124 \\
3.336\end{array}$ & 3.676 & $\begin{array}{l}33.184 \\
3.645\end{array}$ & $\begin{array}{l}102.613 \\
108.890\end{array}$ & $\begin{array}{l}6.065 \\
8.5652\end{array}$ & 37.740 & 15.322 \\
\hline & 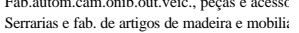 & $\begin{array}{l}1.530 \\
39.284\end{array}$ & 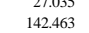 & 232.8473 & $\begin{array}{l}188.222 \\
188.331\end{array}$ & 128.389 & $\begin{array}{r}33.036 \\
141.060\end{array}$ & $\begin{array}{l}3.5008 \\
38.636\end{array}$ & $\begin{array}{l}32.043 \\
126.467\end{array}$ & 221.830 & $\begin{array}{l}85.0 .02 \\
161.766\end{array}$ & $\begin{array}{l}61.844 \\
104.040\end{array}$ & $\begin{array}{l}23.6012 \\
108.062\end{array}$ \\
\hline & Indústria de papel e gráfica & 7.769 & 53.975 & 166.641 & 119.245 & & & 7.107 & & 166.467 & & 69.242 & 31.684 \\
\hline & Indústria & & 9.888 & 32.259 & & & & & & 34.854 & 18.902 & & 7.087 \\
\hline & Fab. Elem. químicos não-petroq.e quím.diver & 5.116 & 32.679 & 84.215 & & 41.212 & 30.375 & 3.682 & 24.051 & 97.426 & 80.326 & 36.334 & 27.680 \\
\hline & $\begin{array}{l}\text { Refino de pertóleo e indústria petroquímica } \\
\text { Fab de rodutus farmacêticicos ed perfumat }\end{array}$ & 1082 & 3.883 & 26.138 & 32.689 & 19.656 & 5.234 & 603 & 5.317 & $\begin{array}{l}24.088 \\
55,323\end{array}$ & 26.693 & 18.699 & 1.199 \\
\hline & 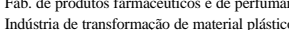 & $\begin{array}{l}1.082 \\
1.999\end{array}$ & $\begin{array}{l}11.465 \\
2.408\end{array}$ & $\begin{array}{l}50.93 \\
75.162\end{array}$ & $\begin{array}{l}28.932 \\
5.7243\end{array}$ & 26.6953 & $\begin{array}{r}9.450 \\
10.534\end{array}$ & 1.726 & 18.6430 & $\begin{array}{l}535.233 \\
79.733\end{array}$ & 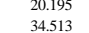 & & 12.278 \\
\hline 16 & $\begin{array}{l}\text { Industrata } \\
\text { Indústrat té }\end{array}$ & 1.999 & $\begin{array}{l}2.1408 \\
57.663\end{array}$ & 1471184 & $\begin{array}{l}3.1243 \\
100.957\end{array}$ & & & & & & & & t \\
\hline & Fabricąât & 434 & 177.038 & (38. & 434.6 & & & & & . & & & 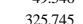 \\
\hline & & 187 & 116. & 152712 & & & & & & $6.8 \mathrm{~s}$ & & & \\
\hline & Industrit & 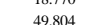 & & & & & & & & & & & \\
\hline & Indústrias dive & 10.806 & 54.749 & 92.291 & 60.399 & 20.13 & & 25.543 & & & & & 813 \\
\hline & Serviços industriais de utilidade pública & 182 & 9.112 & 78.438 & 114.807 & & 36.063 & & & 60.517 & 103.875 & & 45.074 \\
\hline & Cons & 70.732 & 440 & 1.130 .977 & 1.062 .999 & & & 61 & & & & & 481.042 \\
\hline & Comé & 71. & & 2.247 .888 & 2.210 .703 & & & & 5 & 2.349 .668 & & & 1.388.598 \\
\hline & Trar & 118.630 & 159 & & & & & 272.768 & 187 & & & & 385.196 \\
\hline & & 779 & & & & & & & & & & & 815 \\
\hline & & 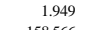 & & 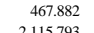 & 99.802 & & 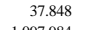 & & & 669.824 & 251.320 & & 768 \\
\hline & sàs famílias & 158.566 & 703.410 & $\begin{array}{l}2.115 .793 \\
{ }_{406963}\end{array}$ & $\begin{array}{l}2.033 .491 \\
302591\end{array}$ & 1.373 .056 & $\begin{array}{l}1.097 .984 \\
27345\end{array}$ & 223.016 & 812.749 & 2.304 .615 & $\begin{array}{r}1.833 .171 \\
406511\end{array}$ & 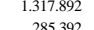 & 1.133.757 \\
\hline & $\begin{array}{l}\text { Servivosi } \\
\text { Aluguel de }\end{array}$ & $\begin{array}{r}10.2 \\
1.2 \\
\end{array}$ & $\begin{array}{l}107.124 \\
29.115\end{array}$ & $\begin{array}{l}4969.963 \\
67.597\end{array}$ & $\begin{array}{l}382 \\
86\end{array}$ & $\begin{array}{l}228.111 \\
46.718\end{array}$ & & 11.07 & & $\begin{array}{l}608.180 \\
65.912\end{array}$ & & & \\
\hline 30 & Admin & 25.680 & & 1.57 & 1.745 & & & & & 1.616.243 & 1.926 .326 & & 76 \\
\hline 31 & ados não-mercantis & 5077 & T37.1.27 & 1.1.138.284 & (1) & 07.1834 & 420.0404 & 年 & 038.560 & 1.285.771 & 938.271 & 598.632 & \\
\hline & & & 6.717 .827 & 17.100.945 & 15.484 .049 & 9.999.369 & 7.531 .633 & 2.895.358 & 7.011.805 & 16.621 .190 & 13.700 .560 & 0.714 .750 & 8.307.837 \\
\hline
\end{tabular}


ANEXO T - Número de pessoas ocupadas por idade em cada setor - 1993/1995.

\begin{tabular}{|c|c|c|c|c|c|c|c|c|c|c|c|c|c|}
\hline & \multirow{2}{*}{ Setor } & \multirow{2}{*}{\multicolumn{6}{|c|}{$\begin{array}{ll}1993 \\
\text { nos } & 30 \text { a }\end{array}$}} & \\
\hline & & & & & & & & & & anos & & & \\
\hline 1 & Agropecuária & 814.049 & 2.199 .317 & 3.914 .192 & 3.425.026 & 3.251 .586 & 1.967 .430 & 385.507 & 2.911 .585 & 3.740 .541 & 2.869 .663 & 2.475 .576 & 2.780 .128 \\
\hline 2 & Extrativa mineral (exceto combustiver & 16.854 & 30.027 & 111.110 & 39.772 & 41.077 & 29.360 & 635 & 5.426 & 36.187 & 122.016 & 33.141 & \\
\hline & t.de petróleo e gás natural, carvão e ou & & & 5.472 & 14.990 & 6.933 & 1.121 & & & 7.481 & 16.713 & 5.753 & \\
\hline & e miner: & 22.056 & 83.593 & 148.636 & 93.679 & 83.200 & 37.73 & 13.122 & 75.872 & & 66.923 & 83.729 & 44. \\
\hline 5 & $\mathrm{a}$ & 5.768 & 70.503 & 224.820 & 236.446 & 144.695 & & 12.925 & & & & 206.690 & 107.499 \\
\hline & tacaja & & 39.295 & 112.146 & 0132 & & & 2.382 & & & & 86.156 & 38.314 \\
\hline 8 & 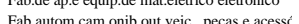 & $\begin{array}{r}581 \\
1295\end{array}$ & 22.7799 & 10062.239 & 10.1060 & 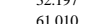 & 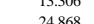 & & 望.010 & 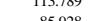 & 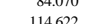 & $\begin{array}{l}43.777 \\
0379\end{array}$ & 21.954 \\
\hline & Serrarias e fab. de artigos de ma & $\begin{array}{l}1.293 \\
30.746\end{array}$ & $\begin{array}{l}232.799 \\
125.733\end{array}$ & $\begin{array}{l}1030.422 \\
239.219\end{array}$ & 169.1600 & $\begin{array}{ll}126.0334 \\
12634\end{array}$ & 年27.000 & 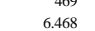 & 58.246 & 烈 & 1110983 & 222.204 & $\begin{array}{l}22.004 \\
181.019\end{array}$ \\
\hline & Indústria c $\mathrm{C}$ & 6.108 & 41.165 & 126.687 & 131.143 & 62.088 & 41.510 & 16.054 & 19.569 & 159.611 & 92.859 & 65.022 & \\
\hline & borracha & & 5.023 & 29.285 & 18.789 & 13.696 & & 1.236 & 4.699 & & 939 & 14.630 & \\
\hline & im.diver & 990 & & 79.956 & 77.6 & $52.8>2>2>0$ & on & 166 & 2.519 & & & & \\
\hline 13 & Refino de petróleo e indústria pett & & 1.457 & 18.345 & 32.233 & 19.571 & 5.2. & & & 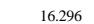 & 7.012 & & 2.562 \\
\hline 14 & b. de produtos & 1.398 & 12.542 & 53.450 & 37.561 & 14919 & 6.230 & 7.569 & 16.103 & 14.403 & 28.766 & & 10.916 \\
\hline & $a^{-}$ & & & & & 22. & & & & & & & 2072 \\
\hline 16 & Induistria textil & 6.675 & 48 & 136.576 & 92.387 & 43.014 & 37.100 & 1.480 & 20.488 & 89.182 & 121.080 & & 30.967 \\
\hline 17 & Fabricac: & 41.797 & & & & 368.326 & 284.302 & 32.672 & 127.375 & & & & 393.024 \\
\hline & & & & & & & & & & & & & 41.635 \\
\hline 19 & tos em ge & 47.481 & 181.775 & 490.719 & 361.789 & 228.646 & 171.690 & 38.548 & 130.487 & 385.032 & 424.516 & 347.670 & 209.548 \\
\hline 20 & $\begin{array}{l}\text { Indústrias } \\
\text { Servicosi }\end{array}$ & $\begin{array}{l}8.419 \\
117\end{array}$ & & & & & & 1.676 & & & & & 6.309 \\
\hline & $\begin{array}{l}\text { Servyços industranas de utlidade publica } \\
\text { Construča civil }\end{array}$ & 49.532 & $\begin{array}{r}8.831 \\
424910\end{array}$ & 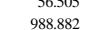 & $\begin{array}{l}111.426 \\
893.022\end{array}-20$ & $\begin{array}{r}92.063 \\
677.344\end{array}$ & $\begin{array}{l}46.153) \\
516.610\end{array}$ & .108 & $\begin{array}{l}18.0 .42 \\
310.45\end{array}$ & $\begin{array}{l}18.047 \\
802.621\end{array}$ & $\begin{array}{l}58.666 \\
912568\end{array}$ & $\begin{array}{l}1171.429 \\
6952.287\end{array}$ & 22.869 \\
\hline 23 & 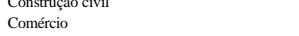 & 65.470 & $\begin{array}{l}484.900 \\
584705\end{array}$ & $\begin{array}{r}2.588 .822 \\
2.1423\end{array}$ & $\begin{aligned} 2.3930 .022 \\
2.87\end{aligned}$ & $\begin{array}{l}0.489 .643 \\
1.443\end{array}$ & & 9.784 & 300.215 & $\begin{array}{r}8.724 .22 .268 \\
2.268\end{array}$ & $\begin{array}{l}9.2202 .531 \\
2.031\end{array}$ & $\begin{array}{r}1.857 .2818 \\
1.875\end{array}$ & $\begin{array}{l}1.744 .718 \\
1.718\end{array}$ \\
\hline 24 & Transp & 189.416 & & & 454 & & & 139.339 & & 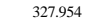 & 968.233 & 91 & 689.988 \\
\hline 25 & and & & & & & & & & & & & & ( \\
\hline 26 & Institiuic & 197 & & 332.777 & 100025 & $\begin{array}{r}148.230 \\
131203\end{array}$ & & & & 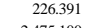 & 18 & 69 & 79.641 \\
\hline 28 & $\begin{array}{l}\text { ss s̀ familias } \\
\text { sì às empresas }\end{array}$ & $\begin{aligned} 207.331 \\
8841\end{aligned}$ & $\begin{array}{l}781174 \\
111177\end{array}$ & $\begin{array}{l}2.312 .596 \\
58670\end{array}$ & $\begin{array}{l}1.980 .258 \\
485679\end{array}$ & $\begin{array}{l}1.322 .238 \\
254313\end{array}$ & $\begin{array}{l}1.007 .903 \\
721319\end{array}$ & 209.477 & 4.976 & $\begin{array}{l}2.475 .100 \\
5092\end{array}$ & $\begin{array}{l}2.028 .528 \\
413698\end{array}$ & $\begin{array}{l}1.875 .236 \\
551609\end{array}$ & 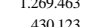 \\
\hline & sas empresas & 8.841 & & $\begin{array}{l}58.2700 \\
51.606\end{array}$ & $\begin{array}{l}488.649 \\
48.433\end{array}$ & 2060.413 & 271.319 & $\begin{array}{l}1.164 \\
209\end{array}$ & $\begin{array}{l}108.9 \\
19.2\end{array}$ & 540.912 & 415.568 & $\begin{array}{l}2017.699 \\
77.139\end{array}$ & 6.0.125 \\
\hline & 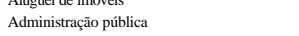 & & & & & & & 4.280 & & 1.176.686 & & 55 & \\
\hline 31 & rados não-mercantis & 13 & & 1.3 & 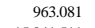 & & & 276.884 & & 1.479.677 & 1.254 .300 & 14 & 47 \\
\hline & & 2.148 & 656.156 & 16.758 .634 & 15.041.511 & .423.609 & 7.878.242 & 1.266.951 & 6.650 .328 & 863.504 & 14.810 .007 & 960.6600 & . 674.6 \\
\hline
\end{tabular}


ANEXO T - Número de pessoas ocupadas por idade em cada setor - 1996 - 1997.

\begin{tabular}{|c|c|c|c|c|c|c|c|c|c|c|c|c|c|}
\hline & \multirow[t]{2}{*}{ Setor } & \multirow{2}{*}{\multicolumn{6}{|c|}{ 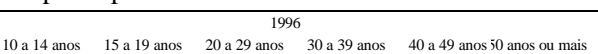 }} & \multicolumn{6}{|c|}{1997} \\
\hline & & & & & & & & $10 \mathrm{a} 14$ anos & 15 a 19 anos & 20 a 29 anos & 30 a 39 anos & & \\
\hline$T$ & Agropecuária & 846.906 & 1.558 .431 & 3.571 .553 & 3.343 .301 & 2.565 .704 & 2.019 .905 & 752.086 & 1.795 .962 & 3.258 .803 & 3.340 .890 & 2.458 .100 & 2.073 .159 \\
\hline 2 & Extrativa mineral (exceto c c & 5.118 & 30.497 & 49.777 & 63.248 & 25.530 & 32.430 & 5.461 & 21.559 & 54.798 & 53.853 & 41.655 & 27.674 \\
\hline 3 & Ext.de petróleo e gás natural, carvão e outros & & & 2.550 & 13.999 & 7.514 & 2.237 & & & 2.657 & 13.162 & 11 & 2.471 \\
\hline & Fabricaçăo de minerais não-metálicos & 18.787 & 69.027 & 140.590 & 95.967 & 68.150 & 43.478 & 16.799 & 69.217 & 142.649 & 107.318 & 368 & 35.749 \\
\hline & 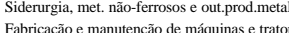 & 6.093 & $\begin{array}{l}81.738 \\
34986\end{array}$ & $\begin{array}{l}218.922 \\
128945\end{array}$ & 233.294 298 & 165.013 & 540 & 14.717 & 83.144 & 233.429 & 209.872 & 161.748 & 69.190 \\
\hline 7 & 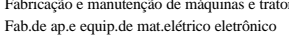 & $\begin{array}{l}6.26 \\
1.551\end{array}$ & $\begin{array}{l}34.386 \\
24.305\end{array}$ & $\begin{array}{l}128.945 \\
94.833\end{array}$ & $\begin{array}{l}16.088 \\
74.070\end{array}$ & $\begin{array}{l}88.173 \\
42.268\end{array}$ & $\begin{array}{l}4.3051 \\
1.673\end{array}$ & $\begin{array}{l}2.889 \\
1.528\end{array}$ & 27.931 & 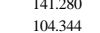 & $\begin{array}{l}119.263 \\
60.912\end{array}$ & $\begin{array}{l}84.444 \\
45976\end{array}$ & $\begin{array}{l}37.314 \\
13159\end{array}$ \\
\hline 8 & 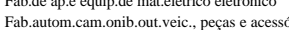 & 1.095 & 16.454 & 86.561 & 103.604 & $\begin{array}{l}4.2680 \\
67809\end{array}$ & 10.9377 & 1625 & 22358 & & 96966 & & \\
\hline & arias e fab & 24.402 & 124.600 & 244.5 & & & 108. & $\begin{array}{l}2.0252 \\
24252\end{array}$ & & & 109604 & & 21.509 \\
\hline & istria & ${ }_{5.108}^{2.402}$ & 50.178 & 129.809 & 043 & 76.5 & 38.533 & 年, & & 137 & 106967 & & . \\
\hline & ústria c & 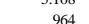 & 00.110 & 14725 & $0+3$ & 10.9 & . & & & & & & \\
\hline & Fab. Elem. químicos não-petroq.e quím.diver & 2.614 & 14.136 & 62.271 & & 46.2 & 22.169 & 820 & 13. & & 81.774 & 46.133 & $\begin{array}{l}19.017 \\
19.17\end{array}$ \\
\hline & leo e indústria petros & & 834 & 13.796 & 20.852 & 19.722 & 6.42 & 711 & 2.267 & 15.581 & 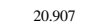 & 14.936 & 5.497 \\
\hline 14 & Fab. de $\mathrm{p}$ & 1.220 & 8.130 & 42.955 & 34.304 & 25.997 & 13.094 & 256 & & 51.170 & 800 & & 9.727 \\
\hline & Indústria de transf & & & 62.288 & & & 9.371 & 1.650 & & 66.947 & & & 10.585 \\
\hline & & 8.325 & & 76.941 & & & & & & 82.167 & & & 26.329 \\
\hline & Fabricaçą & 29.307 & & .453 & & & & & & & & & 283.916 \\
\hline 18 & Fab. de calcados e de artigos de couro e pele: & 8.166 & & $\begin{array}{l}117.781 \\
453209\end{array}$ & $\begin{array}{r}94.171 \\
405816\end{array}$ & $\begin{array}{r}43.062 \\
{ }_{256514}\end{array}$ & & 8.639 & $\begin{array}{r}62.893 \\
173.358\end{array}$ & 106.577 & & 35.709 & 22.179 \\
\hline & Indístria de alimentos em geral & 41.836 & 176.139 & 458.329 & 405.816 & $\begin{array}{l}256.514 \\
33653\end{array}$ & $\begin{array}{l}147.266 \\
18802\end{array}$ & $\begin{array}{l}41.320 \\
3.853\end{array}$ & $\begin{array}{c}173.358 \\
33655\end{array}$ & 453.529 & 388.420 & 267.063 & 156.310 \\
\hline${ }_{21}^{20}$ & $\begin{array}{l}\text { Indusustrasas diversas } \\
\text { Servicos industriais de utilidade pública }\end{array}$ & $\begin{array}{l}5.219 \\
213\end{array}$ & $\begin{array}{l}4.7141 \\
13.387\end{array}$ & 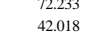 & $\begin{array}{l}55.733 \\
75.157\end{array}$ & $\begin{array}{l}32.653 \\
78.872\end{array}$ & & ${ }_{907}^{3.833}$ & & $\begin{array}{l}73.68 \\
39.887\end{array}$ & & & 26.158 \\
\hline 22 & Construçąa & 15 & 350 & 904.413 & & & & 36.546 & & 1.004 .503 & & & 539.342 \\
\hline 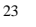 & 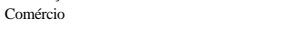 & & & 2.062 .416 & 2.703 & 1.989 .547 & & & & 2.240 .404 & 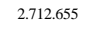 & & 1.334.318 \\
\hline & Transporte & 123.524 & 137.684 & 374 & & & 456.461 & 239.916 & & 480.124 & & 138.462 & 440.842 \\
\hline 25 & Comunicaấes & 3.0 & & 47.541 & & & & 1.245 & & 49.288 & & 2.111 & 12.798 \\
\hline & $\begin{array}{l}\text { Instituicóe } \\
\text { Servicos } p \text { P }\end{array}$ & $\begin{array}{r}2.249 \\
178,350\end{array}$ & 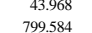 & $\begin{array}{r}238.137 \\
2.484 .657\end{array}$ & $\begin{array}{r}268.439 \\
2.422 .373\end{array}$ & $\begin{array}{r}1.161 .127 \\
1.700674\end{array}$ & $\begin{array}{r}35.581 \\
1.2061\end{array}$ & $\begin{array}{r}947 \\
214829\end{array}$ & & $\begin{array}{r}246.410 \\
248791\end{array}$ & $\begin{aligned} 268.834 \\
2546671\end{aligned}$ & 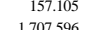 & $\begin{array}{r}37.096 \\
1.278997\end{array}$ \\
\hline 28 & $\begin{array}{l}\text { ast familias } \\
\text { às empresas }\end{array}$ & 19.3. & & 2.:484.4037 721.935 & & & & 3.6 & 158 & & & & \\
\hline & Alug & & & 72.009 & & & & & & & & & \\
\hline 30 & açăo pưblica & & & 1.242 .315 & 1.710 .663 & & & & & 153 & & & \\
\hline & Servicos privados näo-mercantis & 203.079 & 248.371 & .432 .445 & 1.269 .382 & & 98.002 & 5.051 & & & & & \\
\hline & & & & 15.660 .620 & 16.296 .392 & 121.554 & 304.880 & 41.969 & 200.247 & 668.655 & 6.484.997 & 1.936.148 & 390.884 \\
\hline
\end{tabular}


ANEXO T - Número de pessoas ocupadas por idade em cada setor - 1998 - 1999.

\begin{tabular}{|c|c|c|c|c|c|c|c|c|c|c|c|c|c|}
\hline \multirow{2}{*}{\multicolumn{2}{|c|}{ Setor }} & \multirow[b]{2}{*}{$10 \mathrm{a} 14$ anos } & \multirow{2}{*}{\multicolumn{5}{|c|}{$\begin{array}{l}1998 \\
29 \text { anos } 30 \text { a } 39 \text { anos } \quad 40 \text { a } 49 \text { anos } 50 \text { anos ou mais }\end{array}$}} & \multirow{3}{*}{$\begin{array}{l}10 \text { a } 14 \text { anos } \\
962.304\end{array}$} & \multicolumn{3}{|c|}{$\begin{array}{r}1999 \\
\text { los } 20 \text { a } 29 \text { anos }\end{array}$} & \multirow{2}{*}{\multicolumn{2}{|c|}{ a ty a anost }} \\
\hline & & & & & & & & & 15 a 19 anos & $\frac{20 \mathrm{a} 29 \text { anos }}{3.358511}$ & $\begin{array}{ll}30 \text { a } 39 \text { anos } \\
3200626 \\
\end{array}$ & & \\
\hline 1 & Agropecuária & & 1.786 .182 & 3.208 .133 & 3.063 .065 & 2.338.018 & 2.007 .893 & & & 3.358.511 & & 6.709 & \\
\hline & 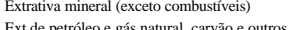 & 8.964 & 23.346 & 66.0200 & $\begin{array}{l}44.953 \\
0.988\end{array}$ & 37.656 & 26.762 & 3.724 & & 49.162 & 17.106 & & \\
\hline & & & & & & & 1.880 & & & 6.450 & 12.074 & & \\
\hline 4 & Fabricaçăo de minerais não-metálicos & 11.317 & 56.589 & 136.248 & 107.221 & 67.517 & 34.808 & 10.614 & 61.269 & 149.545 & 108.867 & 63.967 & 36.138 \\
\hline & Siderurgia, met. não-ferrosos e out.prod.metal & 8.690 & 80.072 & 223.217 & 241.694 & 155.270 & 82.557 & 6.764 & 67.118 & 218.391 & 198.877 & 161.841 & 75.409 \\
\hline & Fabricação e manutenção de máquinas e trato & 4.905 & 30.137 & 126.391 & 107.790 & 83.673 & 35.304 & 1.848 & 34.616 & 116.780 & 105.873 & 86.773 & \\
\hline 7 & Fab.de ap.e equip.de mat.el & 2.451 & & 82.257 & 26 & 5 & 16.142 & 671 & 47 & 84.473 & .735 & 03 & 9.972 \\
\hline${ }_{9}^{8}$ & $\begin{array}{l}\text { Fabauton } \\
\text { Serratiane }\end{array}$ & m7 & & 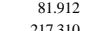 & & 57,945 & 100 & 1.204 & & $\begin{array}{c}94.483 \\
24445\end{array}$ & 91.121 & 12 & 22.595 \\
\hline 10 & $\begin{array}{l}\text { Serraraias s fabb de aratigos d en } \\
\text { Indústria de papel e grafica }\end{array}$ & 2.498 & 108.0101 & $\begin{array}{l}217.310 \\
151.735\end{array}$ & $\begin{array}{l}187.817 \\
19.469\end{array}$ & 58.1.67 1327 & 129768 & 17.567 & $\begin{array}{l}95.516 \\
47.215\end{array}$ & 224.435 & 196.190 & 138.749 & 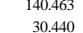 \\
\hline 11 & Indústria da borracha garte & 238 & 3.631 & 13.119 & 12.344 & & 6.614 & & & & $\begin{array}{l}144.26 \\
14807\end{array}$ & & $\begin{array}{l}3.4400 \\
4.368\end{array}$ \\
\hline & Fab. Elem. químicos não-petroq. & & 11.385 & (7) & & 48. & 4.78 & 291 & 7.7 & 66.5 & 63.0 & & 23.9011 \\
\hline & indústria petroquímica & & 2.519 & 13.353 & 14.231 & 13.97 & 5.02 & & 724 & 11.6 & 6 & & 2.835 \\
\hline & & 565 & & & & & & & & & & & \\
\hline & Indústria & & 15.5 & 71.171 & 24 & 2 & & 211 & & 75.931 & & & 15.908 \\
\hline 16 & Indústria têxxil & 3.353 & & & & & & & & 84.464 & & & 27.661 \\
\hline & $F_{i}$ & & & & & & & & & & & & 310.829 \\
\hline 18 & Fab. de $c$ & 3.938 & & 125.383 & 89.949 & 212 & & 6.985 & 53.403 & 112.702 & 96.223 & & 17.332 \\
\hline & In & 39.234 & & 473.616 & 377.195 & & & & 158.8 & 483.692 & 381.4 & & 152.671 \\
\hline & & 7.924 & & & & & & (2) & & & & & 53 \\
\hline & Se & & & & & & & & & & & & 60 \\
\hline & Con & $\begin{array}{l}35.985 \\
49946\end{array}$ & & $\begin{array}{l}1.079 .328 \\
2.171951\end{array}$ & $\begin{array}{l}1.076 .140 \\
2630260\end{array}$ & & & & & 137.412 & & 236 & $\begin{array}{l}597.639 \\
1090453\end{array}$ \\
\hline & $\begin{array}{l}\text { Comeré } \\
\text { Transp }\end{array}$ & $\begin{array}{r}49.546 \\
250.052\end{array}$ & & $\begin{array}{l}2.1717 .951 \\
\text { r63.429 }\end{array}$ & $\begin{array}{r}2.630 .269 \\
561.747\end{array}$ & $\begin{array}{l}2.246 .0 .23 \\
360.355\end{array}$ & 426.628 & $\begin{array}{l}399.951 \\
163.747\end{array}$ & $\begin{array}{l}3922.293 \\
195872\end{array}$ & $\begin{array}{l}1.891 .791 \\
482714\end{array}$ & $\begin{array}{l}3.003 .225 \\
652519\end{array}$ & $\begin{array}{l}2.067 .1 .188 \\
470281\end{array}$ & $\begin{array}{l}1.9294 .453 \\
50567\end{array}$ \\
\hline & $\begin{array}{l}\text { Transp } \\
\text { Comur }\end{array}$ & $\begin{array}{r}250.052 \\
1.615\end{array}$ & $\begin{array}{l}31.088 \\
13.838 \\
3\end{array}$ & $\begin{array}{r}40.3429 \\
64.050\end{array}$ & $\begin{array}{l}501.14 / 1 \\
63.375\end{array}$ & & $\begin{array}{r}\begin{array}{r}22.028 \\
13.912\end{array}\end{array}$ & 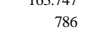 & & $\begin{array}{l}482.144 \\
78.518\end{array}$ & 54.910 & & 8.1567 \\
\hline 26 & & 301 & & & & & & 100 & & & & & 年 \\
\hline & & 195.565 & & & 2.550 & & 1.344 & 181.87 & & 2.603 & & & 1.455.191 \\
\hline 28 & & 7.036 & & & & & & 3.0. & & & & & \\
\hline & & & & & & & & & & & & & \\
\hline 30 & & 6.180 & 214 & 1.223.880 & 1.755.792 & 248 & 802 & 13.821 & 188.005 & 07 & & 06 & 844.547 \\
\hline 31 & não-mercantis & 0.596 & 769.806 & 470.294 & 1.345.010 & .025.464 & $\begin{array}{l}663.730 \\
884784\end{array}$ & 133.614 & 739.405 & 1.530 .000 & 450.056 & $\begin{array}{l}1.030 .138 \\
2677277\end{array}$ & \\
\hline & & & . 4.978 & 40.449 & 2011.363 2010 & 年 183.206 & 84.7874 & . 044.091 & 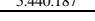 & . 5.841 .097 & 6.978.095 & 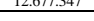 & 18.482 \\
\hline
\end{tabular}


ANEXO U - Número de pessoas ocupadas por idade de ingresso no mercado de trabalho - 1990/1992.

\begin{tabular}{|c|c|c|c|c|c|c|c|c|c|c|c|c|}
\hline & \multirow[t]{2}{*}{ Setor } & \multirow{2}{*}{\multicolumn{5}{|c|}{ 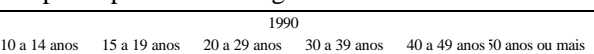 }} & \multicolumn{6}{|c|}{1992} \\
\hline & & & & & & & $10 \mathrm{a} 14$ anos & 15 a 19 anos & 20 a 29 anos & 30 a 39 anos & $40 \mathrm{a} 49$ anos 0 anos & os ou mais \\
\hline 1 & $\begin{array}{l}\text { Agropecuária } \\
\end{array}$ & & & & & & & 3.441 .144 & & & & \\
\hline 2 & Exrrativa mineral (exceto combustíveis) & & & & & & 203.906 & 49.174 & 6.633 & 1.388 & & \\
\hline 3 & Ext.de petróleo e gás natural, carvão e outros & & & - & & - & 11.367 & 17.078 & 4.255 & & & \\
\hline 4 & Fabricação de minerais não-metálicos & & 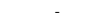 & - & & - & 366.714 & 94.518 & 16.611 & 957 & & \\
\hline & 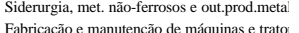 & - & - & - & & - & $\begin{array}{l}472.318 \\
253209\end{array}$ & 279.250 & $\begin{array}{l}37.585 \\
251167\end{array}$ & 1.346 & & \\
\hline${ }_{7}^{6}$ & 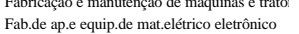 & - & - & : & & - & $\begin{array}{l}252.329 \\
119.643\end{array}$ & $\begin{array}{l}155.504 \\
106.827\end{array}$ & $\begin{array}{l}256.167 \\
2678\end{array}$ & - & 372 & - \\
\hline 8 & Fab.autom.cam.onib.out.veic., pecas e acessí & - & - & 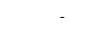 & & - & 176.932 & 123.151 & 16.216 & & & \\
\hline & Serrarias e fab. de artigos de madeirae mobilit & & - & - & & - & 565.554 & 174.491 & 15.550 & 3.173 & 1.116 & 917 \\
\hline & Indústria de papel e gráfica & & & - & - & & 230.502 & 170.038 & 32.750 & 5.466 & 445 & \\
\hline 11 & 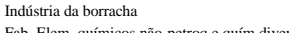 & - & - & 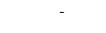 & & - & $\begin{array}{r}45.860 \\
15035-200\end{array}$ & 23.470 & 5.570 & & & - \\
\hline 13 & 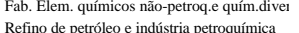 & - & - & - & & - & 157.035 & 90.900 & 20.436 & 1.130 & & \\
\hline & $\begin{array}{l}\text { Retino de petroleo e endustran petroquimica } \\
\text { Fab. de produtos farmacêtucos e de perfumat }\end{array}$ & & 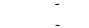 & & & 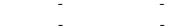 & $\begin{array}{l}29.014 \\
5987\end{array}$ & $\begin{array}{l}32.473 \\
47294\end{array}$ & 15013 & 906 & & \\
\hline & Indústria de transformaçăo de material plástic & & & & & & 93.026 & 55.808 & 16013 & 3.30 & & - \\
\hline & Indústria têxtil & & 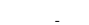 & & & $\therefore$ & 231928 & 10000 & 15618 & 1546 & 438 & \\
\hline & Fabricacẵo de artigos do vestuário e acessórii & & & - & - & & 913.922 & 430.900 & 1232.235 & 23.586 & 5.547 & 1.710 \\
\hline & Fab. de calcados e de artigos de couro e pele: & & & & & & 311945 & 77 787 & 1447 & 2020 & & \\
\hline & Indústria de alimentos em geral & & - & & & & 984.970 & 440.372 & 76.657 & 5.780 & 5.309 & 1.612 \\
\hline & Indústrias diversas & - & - & & & & 171.026 & 97.002 & 13.925 & 4.170 & 677 & \\
\hline 21 & Serviços industriais de utilidade pública & - & - & - & & & 129.379 & 122.917 & 37.572 & 832 & & - \\
\hline & Construção civil & & - & & & - & 2.429 .758 & 914.968 & 102.137 & 4.337 & & \\
\hline & Comércio & 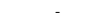 & - & - & & - & 3.968 .360 & 2.985 .237 & 777.242 & 17.661 & & 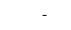 \\
\hline & Transporte & - & - & - & & - & 1.596.271 & 362.509 & 81.519 & & & - \\
\hline & Comunicaçóes & - & - & - & & - & $\begin{array}{r}58.122 \\
26709\end{array}$ & 81.912 & 32.166 & & & - \\
\hline & $\begin{array}{l}\text { Institicicōes financeiras } \\
\text { Servicos restados às familias }\end{array}$ & - & - & 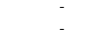 & & & $\begin{array}{r}267.599 \\
3.973 .181\end{array}$ & $\begin{array}{r}472.971 \\
2500599\end{array}$ & $\begin{array}{r}127.453 \\
103780\end{array}$ & $\begin{array}{r}2.947 \\
9097\end{array}$ & $\begin{array}{r}429 \\
15998\end{array}$ & 6486 \\
\hline & $\begin{array}{l}\text { Samillas } \\
\text { sempresas }\end{array}$ & $\therefore$ & - & & & & 831088 & 653699 & 188860 & $\begin{array}{l}15671 \\
15671\end{array}$ & 3082 & \\
\hline & sur & & . & & & & 3 & 100471 & 28589 & 1097 & & \\
\hline 30 & Administracăo pública & & & - & - & - & 2.607 .320 & 2.297.289 & 1.183 .037 & 145.587 & 43.320 & 3.247 \\
\hline 31 & ivados nâ--mercantis & & & & & & 3.225 .091 & 147.182 & 229.138 & 36.161 & 17.020 & \\
\hline & TOTAL & & & - & - & & 36.330 .979 & 17653906 & 4783650 & 371063 & 95332 & 16480 \\
\hline
\end{tabular}


ANEXO U - Número de pessoas ocupadas por idade de ingresso no mercado de trabalho - 1993/1995.

\begin{tabular}{|c|c|c|c|c|c|c|c|c|c|c|c|c|c|}
\hline & \multirow[t]{2}{*}{ Setor } & \multicolumn{6}{|c|}{1993} & \multicolumn{6}{|c|}{1995} \\
\hline & & $\frac{10 \mathrm{a} 14 \text { anos }}{10600138}$ & $\frac{15 \text { a } 19 \text { anos }}{308045}$ & $20 \mathrm{a} 29$ anos & 30 a 39 anos & 40 a 49 anos 50 an & os ou mais & 10 a 14 anos & 15 a 19 anos & $20 \mathrm{a} 29$ anos & 30 a 39 anos & 40 a 49 anos 0 anos & os ou $\mathrm{n}$. \\
\hline 2 & $\begin{array}{l}\text { Agropeceuarna } \\
\text { Exxratian mineral (excetoto combustiviveis) }\end{array}$ & & & & & & & 12.310 .213 & $\begin{array}{r}1.735 .799 \\
90255\end{array}$ & & & & \\
\hline & 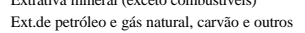 & $\begin{array}{l}219.601 \\
11.648\end{array}$ & $\begin{array}{l}46.622 \\
10.546\end{array}$ & $\begin{array}{l}1.897 \\
7.406\end{array}$ & & - & & 111.5500 & $\begin{array}{l}9.045 \\
1.6612\end{array}$ & $\begin{array}{l}28.555 \\
5554\end{array}$ & & & \\
\hline 4 & Fabricą̧ão de minerais não-metalilicos & 344.640 & $\begin{array}{l}10.4040 \\
106489\end{array}$ & $\begin{array}{l}1.17 .799 \\
17.999-190\end{array}$ & - & & - & 286.845 & 127.685 & 29.371 & & & \\
\hline 5 & Siderurgia, met. não-ferrosos e out.prod.metal & 443.719 & 270.900 & 42.881 & 534 & 265 & & 507.165 & 225.221 & 31.679 & & 76 & \\
\hline & Fabricaçăo e manutençăo de máquinas e trato & & 142.894 & 19.859 & & & - & 202.018 & 198.479 & 20.293 & 1.010 & & \\
\hline & Fab.de ap.e equip.de matelétrico eletrônico & 118.643 & 101.530 & 24.708 & 319 & & - & 96.685 & 153.288 & 17.939 & 8.287 & & \\
\hline & autom.cam. & 200.630 & 104.712 & 20 & 859 & & & 154.262 & & & & & \\
\hline & Serrarias e fab. de artigos de madeira e mobili & 578.545 & 218.407 & 20.530 & 1.019 & & & 567.313 & 262.247 & 13.221 & 284 & 35 & \\
\hline & Indústria de papel e gráfica & 188.758 & 177.754 & 39.182 & 3.006 & & - & 152.150 & 196.894 & 84.326 & 230 & & \\
\hline 11 & Indústria da borracha & 42.580 & 27.168 & 2.253 & & & & 41.885 & 15.970 & 8.749 & 296 & & \\
\hline 12 & Fab. Elem. químicos não-petroq.e quím.diver & 138.170 & 87.401 & 20.738 & 691 & & & 111.151 & 97.096 & 27.898 & 255 & & \\
\hline & Refino de petróleo e indústria petroquímica & & 586 & 10.804 & & & - & 9.191 & 49.889 & 8.519 & & & - \\
\hline 14 & Fab. de produtos farmacêtuticos e de perfumar & 58.749 & 57.613 & 8.728 & 1.009 & & & 47.583 & 63.009 & 17.900 & 8 & & \\
\hline & $\begin{array}{l}\text { Indústrtia de transformaçăo de material plasstic } \\
\text { Indistria texil }\end{array}$ & 112.739 & $\begin{array}{r}44.702 \\
1071.88\end{array}$ & $\begin{array}{l}12.120 \\
1765\end{array}$ & $\begin{array}{l}1.139 \\
2550\end{array}$ & & - & $\begin{array}{r}81.757 \\
141827\end{array}$ & 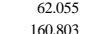 & 20.927 & 160 & 162 & \\
\hline & $\begin{array}{l}\text { Indiśstria êxtil } \\
\text { Fabricacăo de ar }\end{array}$ & $\begin{array}{l}227.948 \\
904336\end{array}$ & $\begin{array}{l}107.188 \\
5717328\end{array}$ & $\begin{array}{l}17.865 \\
121876\end{array}$ & $\begin{array}{l}2.550 \\
26954\end{array}$ & $\begin{array}{r}349 \\
4163\end{array}$ & 943 & $\begin{aligned} 141.827 \\
1003643\end{aligned}$ & $\begin{array}{l}160.803 \\
408752\end{array}$ & $\begin{array}{r}5.114 \\
130115\end{array}$ & 18236 & $\begin{array}{l}162 \\
2706\end{array}$ & 86 \\
\hline 18 & Fab. de calçados e de artigos de couro e pele: & 327.570 & 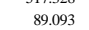 & 11.437 & & & & 215.204 & 137.366 & 6.921 & $\begin{array}{l}1.4200 \\
1.009\end{array}$ & & (0+8 \\
\hline & Indústria de alimentos em geral & 894.317 & 499.088 & 79.960 & 5.208 & 2.546 & 980 & 716.715 & 616.845 & 124.751 & 76.950 & 540 & \\
\hline & 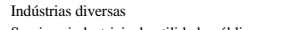 & & & 20.940 & 3.204 & 2.905 & 110 & & 118.791 & 12.534 & 196 & 而 & 1.563 \\
\hline & Serviços industriais de utilidade pública & $\begin{array}{r}151.363 \\
246503\end{array}$ & 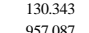 & 32.607 & 787 & & 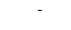 & & & 72.817 & 961 & ing & \\
\hline${ }_{23}^{22}$ & $\begin{array}{l}\text { Construçăa civil } \\
\text { Coméccio }\end{array}$ & 2.465 .003 & $\begin{array}{r}957.087 \\
3426375\end{array}$ & 122.266 & $\begin{array}{r}5.945 \\
63492\end{array}$ & & - & $\begin{array}{l}2.338 .431 \\
3.99921\end{array}$ & $\begin{array}{r}911.958 \\
3.56358\end{array}$ & $\begin{array}{r}177.975 \\
133014\end{array}$ & $\begin{array}{r}799 \\
19989\end{array}$ & $\begin{array}{r}238 \\
6{ }_{6432}\end{array}$ & \\
\hline & $\begin{array}{l}\text { Coméricio } \\
\text { Transporte }\end{array}$ & 4.0.15.8.85 & $\begin{array}{r}3.426 .375 \\
474.716\end{array}$ & $\begin{array}{l}76.147 \\
74331\end{array}$ & 63.492 & 20.401 & - & $\begin{array}{l}3.9399 .921 \\
1.460617\end{array}$ & $\begin{array}{l}3.563 .658 \\
767.226\end{array}$ & $\begin{array}{r}1.330 .114 \\
37.156\end{array}$ & 19.289 & 6.432 & 11.286 \\
\hline & & 70.3 & & & 702 & & & & & & 479 & & \\
\hline & Insti & 290. & & & & & 4// & & & & 471 & & \\
\hline & sol & & 2.77 & & 94.408 & 26.279 & & & & & 110.774 & 63.498 & 1.493 \\
\hline 28 & Serviç & 6 & 676.963 & 243.809 & & ?רe? & 1.043 & & & 386. & 34.905 & & \\
\hline & Alug & 105.704 & 的 & 22.130 & & & & & 15 & & & & \\
\hline 30 & pública & 2.191. & 2.408 .448 & 1 & 121.833 & 23. 3. & 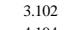 & 63 & 16 & 15 & 2.840 & 4 & 242 \\
\hline 31 & tos não-me & 26.036 & 02.778 & 54.680 & 33.261 & 17.851 & 4.194 & 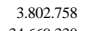 & 19 & 295.587 & 3.773 & 烈 & \\
\hline & ТОтА & 104.777 & 02.398 & 19.892 & 384.916 & 101.001 & 17.315 & 669.330 & 18.834.257 & 391.025 & 114.832 & 00.031 & 5 \\
\hline
\end{tabular}


ANEXO U - Número de pessoas ocupadas por idade de ingresso no mercado de trabalho - 1996 - 1997.

\begin{tabular}{|c|c|c|c|c|c|c|c|c|c|c|c|c|c|}
\hline & Setor & 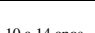 & 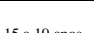 & 199 & & & & & 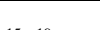 & 1997 & & & \\
\hline 1 & Agropecuária & $\frac{10 \text { a } 14 \text { anos }}{107117109}$ & $\frac{15 \text { a } 19 \text { anos }}{2607019}$ & $20 \mathrm{a} 29 \mathrm{anos}$ & $30 \mathrm{a} 39$ anos & 40 a 49 anos $50 \mathrm{at}$ & nnos ou mais & $\frac{10 \mathrm{a} 14 \mathrm{anos}}{11170.196}$ & $\frac{15 \text { a } 19 \text { anos }}{2121530}$ & $20 \mathrm{a} 29$ anos & $\begin{array}{ll}30 \text { a } 39 \text { anos } \\
14429 \\
\end{array}$ & $\frac{40 \mathrm{a} 49 \text { anos } 0 \text { anos }}{1008}$ & os ou mais \\
\hline 2 & Extrativa mineral (exceto combustiveis) & 170093 & & & & & & & & & & & \\
\hline & Ext.de petróleo e gás natural, carvão o outros & 9.799 & $\begin{array}{l}35.900 \\
11.197\end{array}$ & $\begin{array}{r}18.09 \\
5.09\end{array}$ & - & 296 & & $\begin{array}{l}101.94 \\
10171\end{array}$ & $\begin{array}{l}30.17 \\
11451\end{array}$ & 5.270 & 1.1.393 & & \\
\hline & Fabricação de minerais não-metálicos & 322.599 & 99.358 & 13.783 & 260 & & & 336905 & 101.084 & $\begin{aligned} 1.270 \\
14.196\end{aligned}$ & 414 & & \\
\hline 5 & Siderurgia, met. não-ferrosos e out.prod.metal & 470.172 & 262.478 & 33.284 & 204 & 461 & - & 450.977 & 280.437 & 39601 & 996 & & \\
\hline & & & 130000 & . & & & & 243.725 & 147.151 & 21.844 & 480 & & \\
\hline & Fab.de ap.e equip.de matelétrico eletrônico & 130.698 & 121.050 & 2.352 & - & - & & & & & 1.276 & 645 & \\
\hline 8 & Fab.autom.cam.onib.out.veic., pecas e ac & 183.631 & 86.289 & 21.980 & & & & 167.814 & 104.393 & 16.092 & & & \\
\hline & Serrarias e fab. de artigos de madeira e mobiliti & 629.782 & 205.250 & 19.615 & 476 & 488 & 488 & 582.053 & 233.762 & 18.985 & & & \\
\hline 10 & Indústria de papel e gráfica & 230.296 & 187.260 & 5.417 & & 227 & & 216.974 & 184.922 & 5.326 & 3.388 & 189 & \\
\hline & Indústria da borracha & 36.010 & 17.222 & 1.668 & & & & 29.613 & 20.597 & 2.890 & & & \\
\hline 12 & Fab. Elem. químicos não-petroq.e quím.diver & 141.686 & 73.200 & 14.276 & 1.138 & & & 137.839 & 82.965 & 17.033 & 1.863 & & \\
\hline & fino de perróleo e indústria perroquímica & & & 14.089 & & & - & & & 5.771 & $\mathrm{~s}_{\mathrm{C}}$ & 485 & - \\
\hline 14 & Fab. de $\mathrm{p}$ & & 53.719 & 12.603 & 779 & 514 & & & & 14.682 & & & \\
\hline & $\begin{array}{l}\text { Indúustria de transformaçăo de material plástic } \\
\text { Indústriatêti }\end{array}$ & 106996 & $\begin{array}{l}61.859 \\
80461\end{array}$ & $\begin{array}{l}10.098 \\
1590\end{array}$ & $\begin{array}{r}319 \\
1073\end{array}$ & 529 & - & $\begin{array}{r}98.130 \\
15080\end{array}$ & 76.458 & 8.412 & 840 & 1146 & \\
\hline & 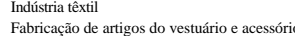 & $\begin{array}{l}149.477 \\
952623\end{array}$ & $\begin{array}{r}80.461 \\
480895\end{array}$ & $\begin{array}{l}15.690 \\
117462\end{array}$ & $\begin{aligned} 1.073 \\
20587\end{aligned}$ & 6485 & 2447 & $\begin{array}{l}156.080 \\
882767\end{array}$ & $\begin{array}{l}68.999 \\
43636\end{array}$ & $\begin{array}{r}9.410 \\
104913\end{array}$ & $\begin{array}{r}840 \\
18.196\end{array}$ & 1.146 & 326 \\
\hline 18 & 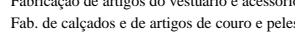 & $\begin{array}{l}92.623 \\
250.480\end{array}$ & $\begin{array}{l}480.895 \\
78.490\end{array}$ & $\begin{aligned} 127.472 \\
12778\end{aligned}$ & 28.587 & 8966 & 2.447 & $\begin{array}{l}82.767 \\
230.088\end{array}$ & $\begin{array}{l}463.356 \\
78.895\end{array}$ & $\begin{array}{l}104.913 \\
10.198\end{array}$ & $\begin{array}{l}18.196 \\
1.667\end{array}$ & 5.962 & 226 \\
\hline & Indústria de alimentos em geral & 922.131 & 459.734 & 90.098 & 10.038 & 2.545 & 1.354 & 942.093 & 446.345 & 83.044 & 7.141 & 1.173 & 203 \\
\hline & Indústrias & 121.8 & & 12.750 & 2.021 & & 321 & & & & 2.408 & & \\
\hline & Serviços it & 49.624 & & 37 . 3 & 376 & & & 129. & & & & & \\
\hline & Construçăa civi & 2.505 .312 & 928.239 & 89.247 & 202 & & & 2.629.446 & 972.377 & 97.150 & 1.166 & 662 & \\
\hline & Comércio & 4.716.440 & 3.252.440 & 696.258 & 68.896 & 5.535 & 4.731 & 4.902.839 & 3.301 .729 & 626.067 & 27.267 & 24.997 & \\
\hline & Trans: & 1.626. & & & & & & & & & & & \\
\hline & & 68.5 & & & 122 & 204 & - & & & & 567 & & - \\
\hline 26 & Institi & 240 & 38 & 125.024 & & & & & & 102.0000 & 223 & & \\
\hline & às famílias & 4.502. & & & 92.3 & 20.291 & 3.264 & & & 8 & 95.748 & 20.264 & 4.387 \\
\hline 28 & tos às empresas & 978.850 & 890.530 & 291.163 & & 4.394 & 432 & & 1.039 .278 & 261.038 & 12.277 & & \\
\hline & $\begin{array}{l}\text { Aluguel de imóvevis } \\
\text { Administraço püblica }\end{array}$ & $\begin{array}{r}129.357 \\
216026\end{array}$ & $\begin{array}{r}114.605 \\
2018222\end{array}$ & $\begin{array}{r}29.338 \\
1010317\end{array}$ & $\begin{array}{l}4.810 \\
94879\end{array}$ & $\begin{aligned} 1.091 \\
2.5785\end{aligned}$ & & $\begin{array}{r}117.126 \\
2122672\end{array}$ & $\begin{array}{r}114.331 \\
2079169\end{array}$ & $\begin{array}{l}36.479 \\
005704\end{array}$ & $\begin{array}{r}1.132 \\
977212\end{array}$ & 23776 & 467 \\
\hline 31 & $\begin{array}{l}\text { mimistraçáa publica } \\
\text { rvicos privados ño-me }\end{array}$ & & 20.0184 .422 & 289.034 & $\begin{array}{l}9.47911 \\
69.111\end{array}$ & & 1.271 & $\begin{array}{l}2.122 .672 \\
3.647 .624\end{array}$ & $\begin{array}{l}2.079 .169 \\
1.460 .634\end{array}$ & 880.826 & $\begin{array}{l}9.1212 \\
51.788\end{array}$ & 23.756 & \\
\hline & TC & 28.123 & 102.556 & 331.662 & 400.467 & 83.232 & 18.560 & 247.107 & 3.153 .675 & 665.409 & 339.217 & 107.481 & 012 \\
\hline
\end{tabular}


ANEXO U - Número de pessoas ocupadas por idade de ingresso no mercado de trabalho - 1998 - 1999.

\begin{tabular}{|c|c|c|c|c|c|c|c|c|c|c|c|c|c|}
\hline & \multirow[t]{2}{*}{ Setor } & \multicolumn{4}{|c|}{1998} & \multirow{2}{*}{\multicolumn{2}{|c|}{40 a 49 anos 50 anos ou mais }} & \multirow{3}{*}{$\frac{10 \mathrm{a} 14 \mathrm{anos}}{11.979 .091}$} & \multirow{3}{*}{$\frac{15 \mathrm{a} 19 \text { anos }}{2.133 .292}$} & \multicolumn{2}{|c|}{1999} & \multirow{2}{*}{\multicolumn{2}{|c|}{40 a 49 anos 0 anos ou mais }} \\
\hline & & $10 \mathrm{a} 14$ anos & 15 a 19 anos & $20 \mathrm{a} 29$ anos & 30 a 39 anos & & & & & $20 \mathrm{a} 29$ anos & 30 a 39 anos & & \\
\hline 1 & Agropecuária & $\begin{array}{ll}10.976 .021 \\
\end{array}$ & 1.975 .529 & 310.128 & 31.222 & & & & & 251.017 & & & \\
\hline 2 & Extrativa mineral (exceto combustiveis) & 166.582 & 38.249 & 2.869 & - & & & 144.788 & 42.495 & 2.317 & & - & \\
\hline $\begin{array}{l}3 \\
4\end{array}$ & 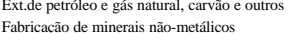 & $\begin{array}{r}9.822 \\
307.953\end{array}$ & $\begin{array}{l}107.73 \\
97137\end{array}$ & 6.626 & 191 & 369 & - & $\begin{array}{r}13.265 \\
317547\end{array}$ & 16.382 & 7.354 & 367 & & \\
\hline 5 & 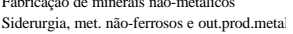 & 478.846 & 277.1287 & $\begin{aligned} 8.049 \\
35.090\end{aligned}$ & 277 & & & & & $\begin{array}{l}14.280 \\
3162\end{array}$ & & 176 & \\
\hline 6 & Fabricação e manutenç̃ăo de máquinas e trato & 230.036 & 132.628 & 25.536 & & & - & 227.455 & 132.344 & 18.983 & 2.117 & & \\
\hline & Fab.de ap.e equip.de mat.elértico eletrônico & 124.104 & 85.774 & 20.162 & 660 & - & & 91.862 & 98.222 & 18.46 & . & & \\
\hline & & & & & & & & & & & & & \\
\hline & Serraraise fabb de artigos de $m$ & 593.974 & 180.821 & 13.279 & 526 & & & 581.108 & 1 & 15.390 & 1.701 & & \\
\hline 10 & Indústria de papel e grifica & 190.023 & 185.380 & 31.199 & 3.314 & 484 & & 194.533 & 195.185 & 26.907 & 467 & 209 & \\
\hline & Indústria da borracha & 28.126 & 17.579 & 1.726 & 869 & & & 29.300 & 15.962 & 1.338 & & & \\
\hline & Fab. Elem. químicos não-petroq.e quím.diver & 135.937 & 65.996 & 17.419 & 1.449 & & & 115.270 & 77.452 & 15.803 & 174 & & \\
\hline 13 & Refino de petróleo e indústria petroquímica & 20.226 & 21.283 & 7.421 & 171 & & - & 20.042 & 18.604 & 6.254 & & & \\
\hline & Fab. de pit & 61.659 & & 12.732 & 673 & 459 & & & & 9.862 & 444 & & \\
\hline & Indústria de transformaçẵo de material plástic & & & & 869 & & & 119.647 & & 9.085 & 866 & & \\
\hline & Indústria têxxtil & 147.313 & 73.638 & 9.783 & 135 & 130 & & 149.517 & & 8.607 & 1.1.27 & & \\
\hline & 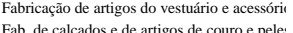 & $\begin{array}{l}861.191 \\
23657\end{array}$ & $\begin{array}{l}425.217 \\
82899\end{array}$ & 102.656 & $\begin{array}{l}15.314 \\
1945\end{array}$ & 2.825 & 2.496 & $\begin{array}{l}861.607 \\
236789\end{array}$ & $\begin{array}{l}473.121 \\
88436\end{array}$ & $\begin{array}{l}95.744 \\
13801\end{array}$ & 15.743 & 4.635 & 350 \\
\hline & $\begin{array}{l}\text { Fabd, de caçadoso e e a artrgos de couro e pele: } \\
\text { Indústria de alimentos em geral }\end{array}$ & $\begin{array}{l}235.557 \\
957.481\end{array}$ & $\begin{array}{l}82.8999 \\
433.202\end{array}$ & $\begin{array}{l}13.999 \\
66.015\end{array}$ & $\begin{array}{l}1.945 \\
8.351\end{array}$ & 2.419 & 832 & $\begin{array}{l}233.789 \\
905.900\end{array}$ & $\begin{array}{r}\begin{array}{r}38.436 \\
464.271\end{array} \\
\end{array}$ & $\begin{array}{l}13.801 \\
76.490\end{array}$ & $\begin{array}{l}2736 \\
7.186\end{array}$ & 1.898 & 656 \\
\hline & Indústrias & & & 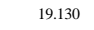 & 1.699 & 730 & & 145.342 & & 24.879 & 1.467 & 159 & \\
\hline & ais de utilidade pública & & & & 251 & & - & & & & 9 & & \\
\hline & & 2.912 .235 & 1.025 .088 & 96.288 & 1.980 & 409 & & & & 93.290 & 1.673 & 168 & 209 \\
\hline & $\begin{array}{l}\text { Comére } \\
\text { CTruspo }\end{array}$ & $\begin{array}{l}5.135 .297 \\
1773991\end{array}$ & $\begin{array}{l}3.086 .422 \\
571070\end{array}$ & $\begin{array}{l}783.957 \\
6038\end{array}$ & 44.650 & 26.574 & - & 5.237 .419 & $\begin{array}{l}3.380 .041 \\
6.77200\end{array}$ & 670.444 & 20.206 & 15.789 & \\
\hline & $\begin{array}{l}\text { Transporte } \\
\text { Compunicacōes }\end{array}$ & $\begin{array}{l}1.773 .491 \\
80228\end{array}$ & $\begin{array}{l}571.070 \\
09813\end{array}$ & $\begin{array}{l}69.338 \\
27324\end{array}$ & 236 & & 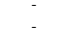 & $\begin{array}{l}1.704 .053 \\
77211\end{array}$ & $\begin{array}{l}647.229 \\
102861\end{array}$ & $\begin{array}{l}32.448 \\
3047\end{array}$ & 592 & & - \\
\hline & & & & & 230 & 458 & & & & & $\begin{array}{l}392 \\
849\end{array}$ & & \\
\hline & nílias & & & & & 18.81 & 7.206 & & & & 2 & 85 & 343 \\
\hline 28 & empresas & 1.086 .477 & & & 12.548 & 920 & & & & & & & 84 \\
\hline & Alu $\mathrm{C}$ & 108.211 & & & & & & & & & & & \\
\hline & & 2.321.594 & 2.070.546 & 1.000.607 & & 144 & S. & 73 & & 1.008 & 80.087 & & \\
\hline 31 & & 3.553.907 & 519.026 & 279.995 & 50. & 198 & 2.356 & 17 & 74 & 275.306 & 48.850 & 16.672 & \\
\hline & TOTAL & 38.081.888 & 17.809 .465 & 4.401.905 & 365.077 & 90.174 & 18.192 & 38.647 .337 & 19.009.753 & 4.259.908 & 309.118 & 109.088 & 3.696 \\
\hline
\end{tabular}


ANEXO V - Número de pessoas ocupadas de acordo com a situação ocupacional - 1992.

\begin{tabular}{|c|c|c|c|c|c|c|c|}
\hline & \multirow[t]{2}{*}{ Setor } & \\
\hline & & $\begin{array}{l}\text { Empregado } \\
\text { com cartira }\end{array}$ & $\begin{array}{l}\text { Empregado } \\
\text { sem carteir }\end{array}$ & $\begin{array}{l}\text { Funcionário } \\
\text { Púlico }\end{array}$ & $\begin{array}{c}\text { Conta } \\
\text { probria }\end{array}$ & Emprege & to remune \\
\hline & & & & & & 337.345 & \\
\hline 2 & Extrativa mineral (exceto combusífiveis) & 97.036 & & & 68.118 & 6.716 & \\
\hline 4 & Ext.de perfóleo gás natural, carvấo outros & $\begin{aligned} 27.884 \\
2025983\end{aligned}$ & $\begin{array}{l}1.733 \\
1.16733\end{array}$ & 3.084 & & & \\
\hline$\frac{4}{5}$ & 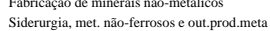 & 254.983 & 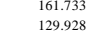 & & 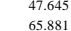 & 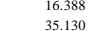 & 27.051 \\
\hline 6 & açao e manutençäo de máquinase erator & & & 1.597 & & & $\begin{array}{l}12.941 \\
10.184\end{array}$ \\
\hline & ap.e equip.de mat & & & & 1.836 & 7.597 & 10.1.240 \\
\hline 8 & & & 31.295 & & 4.384 & 3.081 & \\
\hline 9 & Serrarias e fat & 320.193 & 184.866 & 668 & 181.229 & 35.226 & 38.617 \\
\hline & 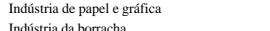 & & 71.341 & 2.679 & 16.805 & 18.438 & \\
\hline 12 & $\begin{array}{l}\text { Indusurtrala a } \\
\text { Fab. Flem. }\end{array}$ & $\begin{array}{l}63.476 \\
233.520\end{array}$ & $\begin{array}{l}11.240 \\
26.013\end{array}$ & & 2.033 & $\begin{array}{r}184 \\
6.047\end{array}$ & \\
\hline & & & & 1.787 & & & 2.019 \\
\hline 14 & Fat & & & 517 & 866 & 659 & \\
\hline 15 & Industriad & 142.915 & & & & & 2.771 \\
\hline 16 & Indústria & & & & 80.051 & 80 & 9.786 \\
\hline & acessorbic & & & 360 & 878.3231 & 32.255 & \\
\hline $\begin{array}{l}18 \\
19\end{array}$ & roe peles & & & $\begin{array}{l}4.437 \\
1.437\end{array}$ & $\begin{array}{r}2.232 \\
20306\end{array}$ & $\begin{array}{l}4.0003 \\
55.954\end{array}$ & 65 \\
\hline & & & & & 69.4 & 8.398 & \\
\hline 21 & tilidade pública & & & & 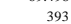 & & 02 \\
\hline 22 & Construçăoc c & 87 & 985 & 9.717 & 182.226 & 76.111 & 0.075 \\
\hline & & & & & 49.805 & 253.762 & 29 \\
\hline 24 & Tran & & & & 1.391 .782 & & 115.110 \\
\hline & & & & & 77 & & \\
\hline & & & & & & & \\
\hline 28 & Ser & & & & & & 18.7 \\
\hline 29 & & & & & & & \\
\hline 30 & & & & 100 & 887 & 1.762 & \\
\hline & & & & 348 390 & 17.056974 & 12924 & \\
\hline
\end{tabular}


ANEXO V - Número de pessoas ocupadas de acordo com a situação ocupacional - 1993/1995.

\begin{tabular}{|c|c|c|c|c|c|c|c|c|c|c|c|c|c|}
\hline \multirow{2}{*}{\multicolumn{2}{|c|}{ Setor }} & \multirow[b]{2}{*}{$\begin{array}{l}\text { Empregado } \\
\text { com carteira }\end{array}$} & & & & \multirow{2}{*}{\multicolumn{2}{|c|}{ Empregador Nẫo remunerado }} & \multirow[b]{2}{*}{$\begin{array}{l}\text { Empregado } \\
\text { com cartira }\end{array}$} & \multirow[b]{2}{*}{$\begin{array}{l}\text { Empregado } \\
\text { sem carteira }\end{array}$} & \multirow{2}{*}{$\begin{array}{l}\text { Funcionario } \\
\text { Publico }\end{array}$} & \multirow{2}{*}{$5 \begin{array}{c}\text { Conta } \\
\text { própria }\end{array}$} & \multirow{2}{*}{\multicolumn{2}{|c|}{$\begin{array}{l}\text { Empregador Não remunerad } \\
\text { ou sem decarac }\end{array}$}} \\
\hline & & & $\begin{array}{l}\text { Empregado } \\
\text { sem actera }\end{array}$ & $\begin{array}{l}\text { Funcionaráio } \\
\text { Pubbico }\end{array}$ & $\begin{array}{c}\text { Conta } \\
\text { proporia }\end{array}$ & & & & & & & & \\
\hline & Agropecuária & & 2.807 .544 & 578.296 & & & & & & & & 1.077 .012 & \\
\hline & Extrativa mineral (exceto oc & 95.167 & & & 47.785 & 14.912 & 11.044 & & & & & 87.555 & \\
\hline & Ie pertroleo e gás natural, car & $\begin{array}{r}26.126 \\
24505 \\
\mathrm{2}\end{array}$ & $\begin{array}{l}1.123 \\
129676\end{array}$ & 2.205 & 146 & & & & 150 & 4.071 & & & \\
\hline & 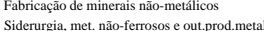 & 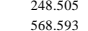 & 129.676 12713 & & $\begin{array}{l}30.977 \\
62.144\end{array}$ & 33.948 & $\begin{array}{l}25.974 \\
1.4972\end{array}$ & & & 224 & $\begin{array}{l}25.714 \\
1057.761\end{array}$ & 6 & \\
\hline & 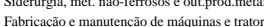 & & 74.713 & 2.316 ${ }^{2.139}$ & $\begin{array}{c}62.1 .144 \\
2.222\end{array}$ & 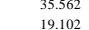 & $\begin{array}{r}14.992 \\
6.995\end{array}$ & 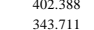 & 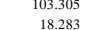 & 97 & $\begin{aligned} 105.761 \\
762\end{aligned}$ & 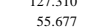 & \\
\hline & 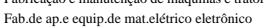 & & & & 1.618 & $\begin{array}{l}1.9102 \\
2.941\end{array}$ & & & & 210 & 8.948 & 756 & \\
\hline & br & & & & 3.394 & 3.845 & 2.755 & & & & & 40.688 & \\
\hline & Serraraias of & 303.858 & 212.138 & 2.517 & 207.279 & 54.772 & 37.937 & 245.527 & 156.345 & & 317.769 & 111.762 & \\
\hline & Indústria di & 300.586 & 60.924 & 6.408 & 13.875 & 22.901 & 4.007 & & & 1.963 & 17.863 & 792 & \\
\hline & $\begin{array}{l}\text { Indistria } \\
\text { Fab Elem }\end{array}$ & & & $\begin{array}{l}451 \\
404\end{array}$ & $\begin{array}{r}569 \\
1.413\end{array}$ & 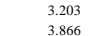 & 528 & & & 234 & 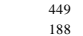 & 6.0.689 & \\
\hline & & & & 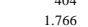 & & & & & & 34 & & & \\
\hline & & & & 1.422 & 145 & 1.999 & & & & 53 & 58 & & \\
\hline & Indústrit: & 144.488 & & & & & & & & & 62 & & \\
\hline & Indústria t! & & & 157 & 48.090 & & & & & 147 & 83 & 12.257 & \\
\hline & & & & & 855.745 & & & & & 12.808 & & & \\
\hline & ro e peles & & & 2.396 & $\begin{array}{r}9.285 \\
145.353\end{array}$ & & & & & $\begin{array}{c}74 \\
797\end{array}$ & 291.699 & & \\
\hline & & & & 2.396 & & & & & & & & & \\
\hline & Serv & & & 60.580 & & & & & & & & & \\
\hline 22 & Construs & 1.119 .458 & 87 & 18.014 & 1.309 .035 & 158 & 69.055 & 35 & 730 & 18.026 & 1.163 .067 & 339.168 & 89. \\
\hline & & & & & & & & & & & & & \\
\hline${ }_{25}^{24}$ & & & & & 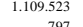 & & 57.991 & & & & & & \\
\hline & & & & & & & & & & & & & \\
\hline & & & & & & & & & & & & & \\
\hline 28 & $\mathrm{Ser}$ & & & & & & & & & 74 & 795 & & 92.14 \\
\hline 29 & el de & & & 0 & & & & & & & 19 & & \\
\hline & & & & & & & & & & & & & 17.43 \\
\hline & năo-me & & & 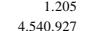 & $\begin{array}{l}22.066 \\
006807\end{array}$ & $\begin{aligned} 122 \\
21844\end{aligned}$ & & 329.978 & & & 08887 & & \\
\hline & & 2.273 & 7.707 & & & & & & & .868 & & & \\
\hline
\end{tabular}


ANEXO V - Número de pessoas ocupadas de acordo com a situação ocupacional - 1996 - 1997.

\begin{tabular}{|c|c|c|c|c|c|c|c|c|c|c|c|c|c|}
\hline & \multirow[t]{2}{*}{ Setor } & & & $\begin{array}{ll}199 \\
\text { Euncionário }\end{array}$ & & \multicolumn{2}{|c|}{ Empreagador Nẵremunerado } & \multirow[b]{2}{*}{ Empregado } & \multirow[b]{2}{*}{$\begin{array}{l}\text { Empregado } \\
\text { sem carteira }\end{array}$} & \multicolumn{2}{|c|}{1997} & \multirow{2}{*}{\multicolumn{2}{|c|}{ Empregador Não remunerado }} \\
\hline & & $\begin{array}{l}\text { Empregado } \\
\text { com carteira }\end{array}$ & $\begin{array}{l}\text { Empregado } \\
\text { sem carteira }\end{array}$ & $\begin{array}{c}\text { Funcionário } \\
\text { Püblico }\end{array}$ & $\begin{array}{c}\text { Conta } \\
\text { proporia }\end{array}$ & Empregador & $\begin{array}{l}\text { Não remunerado } \\
\text { ou sem declaraçăo }\end{array}$ & & & $\begin{array}{c}\text { Funcionario } \\
\text { Pibibico }\end{array}$ & $\begin{array}{c}\text { Conta } \\
\text { prippia }\end{array}$ & & \\
\hline 1 & A gropecuúaria & & & & & 456.893 & & & & & & & \\
\hline${ }^{2}$ & Extrativa mineral (excetoto combustivies) & 70.489 & 58.080 & 32350 & 61.655 & 9.977 & 6.399 & 74.142 & 36.063 & 76.344 & 18.451 & & \\
\hline 4 & 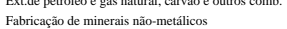 & $\begin{array}{l}22.000 \\
230.532\end{array}$ & 121.418 & & 38.417 & 18.041 & 27.5911 & 237.725 & 38.820 & 1.058 2738 & 47.63 & 1.323 & \\
\hline 5 & 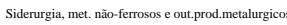 & & 103.150 & 1.335 & 9 & 46.531 & 224 & 521. & 65281 & 119619 & & 426 & $\begin{array}{l}1087 \\
487\end{array}$ \\
\hline 6 & 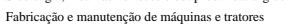 & 3242344 & & & 4.695 & 18.313 & 10.078 & 337.316 & 8.232 & 47.658 & 19993 & & \\
\hline 7 & Fab.de ap.e equip.de mat.eléricico eletrônico & 209.191 & 31.611 & 1.825 & 4.003 & 5.844 & 1.626 & 203.283 & 3.874 & 29.688 & 7.853 & & 202 \\
\hline 9 & 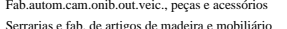 & 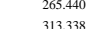 & $\begin{array}{l}164260 \\
218000\end{array}$ & $\begin{array}{l}{ }_{382}^{382} \\
180\end{array}$ & 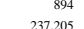 & & 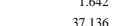 & 254.773 & $\begin{array}{r}2.794 \\
216933\end{array}$ & 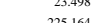 & 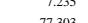 & & 2559 \\
\hline 10 & 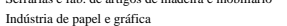 & 206.202 & 69.761 & 4.538 & 12.653 & 3.0.324 & 9.722 & 280.217 & 年 1830 & 81.721 & 30164 & & 2.558 \\
\hline 11 & Indústria da borracha & 48014 & 3.842 & & 1.511 & 1.286 & 247 & 41.133 & 153 & 9.383 & & & 等68 \\
\hline 12 & 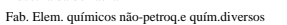 & 194898 & 22.059 & 501 & 3.991 & 6.371 & 2.540 & & 2868 & 28.715 & 8.708 & & \\
\hline 13 & Refino de peróleoe e indústria pertogunimica & & & & & & 226 & & & & 1454 & & \\
\hline 14 & & 103.615 & 16015 & 370 & 2874 & 2826 & & 99632 & & 17.571 & 3.395 & 5.285 & 217 \\
\hline 15 & tria de transformagăio de material plistico & 145.543 & 25.449 & 821 & 1.321 & 4.564 & 2.102 & & 1.763 & 23.950 & & & \\
\hline 16 & Indústria textili & & & & & & 8.866 & 164.812 & 35672 & & 13102 & 50 & 345 \\
\hline 17 & Fabricazáo & 373.29 & 206569 & 635 & 890604 & 55.366 & 476077 & & 1.057 & & 852.161 & 59.517 & 480 \\
\hline 18 & Fab. dec caladado ede artigos de couro peles & 251.196 & & & 6.508 & 11.292 & 7.203 & 223.128 & 7.153 & 68.919 & 22.100 & & \\
\hline & $\begin{array}{l}\text { Indisustria de alimentos } \\
\text {. }\end{array}$ & 888.680 & 285.675 & 4.301 & 166.271 & 69.543 & 74.431 & 843.241 & 183.487 & 279.651 & 170.492 & 427 & 2.701 \\
\hline${ }^{20}$ & Indidstrais diverass & 12626261 & 52.844 & 1.000 & 27.556 & 11.870 & 12.129 & 114.777 & 61.791 & 43.484 & 20.248 & & \\
\hline 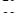 & & & & & & & & & & & & & \\
\hline${ }_{22}$ & Construçăa civil & & & 21.782 & 1.476.334 & 96.772 & & & 1.485.120 & & 301.246 & 4.660 & 3.380 \\
\hline & necrioi & & & 51 & 3.974.743 & 882.949 & 251.547 & 2.697 .648 & & & & & \\
\hline 25 & 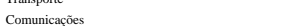 & & & 烈 & 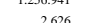 & & 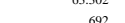 & & & 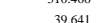 & $\begin{array}{l}8.8367 \\
23009\end{array}$ & & 20 \\
\hline & iicös finance 5 & 598.400 & & & 4 & & & & & & & & 201 \\
\hline 27 & Servicos prestadoso is familias & 3.366.579 & 1.525.736 & 459 & 3307296 & 521.108 & 4.522 & 7.235 & 2.931.794 & 1.558 .932 & 1.021.612 & 1.755 & 2.572 \\
\hline 28 & 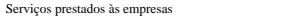 & 1.299.088 & 336.468 & 31.954 & 36.071 & 106.131 & 33.286 & 1.330.615 & 430.754 & 346.056 & 156.633 & & 1.641 \\
\hline 29 & Aluggule de imóveris & & 72.759 & 665 & 74.045 & 22.277 & 2.213 & ${ }^{2}$ & 71.958 & 1884 & 30.146 & & \\
\hline 31 & 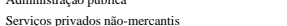 & & & 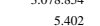 & 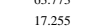 & 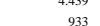 & 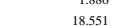 & 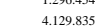 & 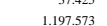 & 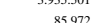 & 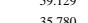 & 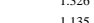 & $\begin{array}{l}2.164 \\
\text { ans }\end{array}$ \\
\hline & & 18.194.54 & $13,029.221$ & $\begin{array}{l}3.8372 .27 \\
\end{array}$ & 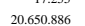 & 2.164 .5131 & (1.883.162 & 年1.366002 & 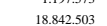 & $\begin{array}{l}12.790 .166 \\
1206\end{array}$ & 5.739 .676 & 38.034 & 47.619 \\
\hline
\end{tabular}




\begin{tabular}{|c|c|c|c|c|c|c|c|c|c|c|c|c|c|}
\hline & \multirow[t]{2}{*}{ Setor } & \multirow{2}{*}{$\begin{array}{l}\text { Empregado } \\
\text { com carteira }\end{array}$} & \multirow{2}{*}{$\begin{array}{l}\text { Empregado } \\
\text { sem carteira }\end{array}$} & \multirow{2}{*}{$\begin{array}{c}{ }^{19} \\
\text { Funciónário } \\
\text { Publico } \\
\end{array}$} & \multirow{2}{*}{$\begin{array}{l}8 \\
\text { Conta } \\
\text { proporia }\end{array}$} & \multicolumn{2}{|c|}{ Empregador Năo remunerado } & \multirow{2}{*}{$\begin{array}{l}\text { Empregado } \\
\text { com carteria }\end{array}$} & \multirow{3}{*}{$\begin{array}{l}\begin{array}{l}\text { Empregado } \\
\text { sem carteria }\end{array} \\
6.361 .1884\end{array}$} & \multirow{2}{*}{ 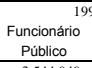 } & \multirow{2}{*}{$\begin{array}{l}\text { Conta } \\
\text { própria } \\
\end{array}$} & \multicolumn{2}{|c|}{$\overline{\text { Empregador Não remunerado }}$} \\
\hline & & & & & & & & & & & & & \\
\hline & Agropecuária & & & & & 795.522 & 35.820 & & & & & 1.000 .262 & 24.236 \\
\hline & 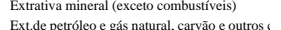 & $\begin{array}{l}83.920 \\
22317 \\
2230\end{array}$ & $\begin{array}{l}38.273 \\
775\end{array}$ & $\begin{array}{l}63.159 \\
3453\end{array}-20$ & & 715 & & $\begin{array}{l}56.423 \\
31828\end{array}$ & & 65.958 & 22.108 & & 412 \\
\hline 4 & 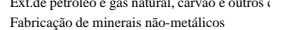 & $\begin{array}{l}22.3717 \\
218.450\end{array}$ & $\begin{array}{r}715 \\
27.243\end{array}$ & $\begin{array}{r}3.433 \\
114.377\end{array}$ & 52.077 & $\begin{array}{r}715 \\
1.163 \\
\end{array}$ & 390 & 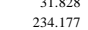 & 33.497 & $\begin{array}{r}4.217 \\
119.903\end{array}$ & $\begin{array}{r}544 \\
42.089\end{array}$ & 734 & 412 \\
\hline & Siderugria, met. nä-ferrososs o out.prod.meta & & & & & 487 & 868 & & & & & & \\
\hline & Fabricacăo e manutençăo de máquinas e trator & 315.418 & 5.073 & 50.035 & 17.674 & & & 292.783 & 6.529 & 60.330 & 21.056 & & 201 \\
\hline & Fab.de ap.e equip.de mat. letritico eletrônico & 193.866 & 4.148 & 22.769 & 9.256 & & 660 & 168.119 & 5.100 & 25.756 & 9.526 & & \\
\hline & mibout.veci., pecaas a acessót & 229.866 & 2.147 & 22.301 & 6.287 & & & 252.059 & 850 & 19.655 & 7.236 & & \\
\hline & Serraraiase fabb, de artigos de maderiac mobili & $\begin{array}{l}309.476 \\
206771\end{array}$ & 225.819 & 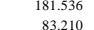 & $\begin{array}{l}71.132 \\
34496\end{array}$ & 635 & & $\begin{array}{l}326.665 \\
207775 \\
20750\end{array}$ & $\begin{array}{l}213.247 \\
17575\end{array}$ & $\begin{array}{l}189.178 \\
73630\end{array}$ & 83.310 & & \\
\hline & 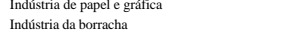 & 286.771 & & $\begin{array}{l}83.210 \\
6.137\end{array}$ & $\begin{array}{l}34.436 \\
3.310\end{array}$ & 108 & & $\begin{array}{l}297.775 \\
37.944\end{array}$ & 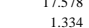 & 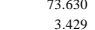 & $\begin{aligned} 28.317 \\
3.892\end{aligned}$ & & \\
\hline & 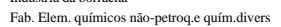 & $\begin{array}{c}50.243 \\
187.283\end{array}$ & 1.474 & 22.873 & 8.927 & 242 & 0.27 & 184.464 & 2.052 & $\begin{aligned} 3.429 \\
16.236\end{aligned}$ & 5.948 & & \\
\hline & Refino de perróleo e indússrria pertroquímica & & 37 & 6.259 & & & & 38.936 & 284 & 5.546 & 135 & & \\
\hline & Fab. de produtos farmacêuticose de perffumar & 111.032 & 158 & 14.869 & 1.655 & & 686 & 101.543 & 1.439 & 15.152 & 1.266 & & \\
\hline & formagăio de material plásicic & & 1.462 & & a & & 520 & 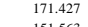 & 370 & 28.102 & 4.418 & & 261 \\
\hline & 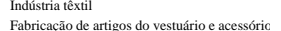 & $\begin{array}{l}195.553 \\
344.035\end{array}$ & 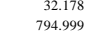 & $\begin{array}{c}25.500 \\
170.595\end{array}$ & $\begin{array}{l}13.769 \\
98.28\end{array}$ & & & 151.563 1563 & $\begin{array}{r}37.645 \\
7769001\end{array}$ & $\begin{array}{l}30.931 \\
0.9618\end{array}$ & 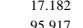 & & 679 \\
\hline & 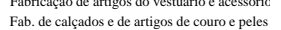 & $\begin{array}{l}3420.0934 \\
22984\end{array}$ & 20.874 & $\begin{array}{l}170.599 \\
60.577\end{array}$ & $\begin{array}{l}98.68 \\
23.066\end{array}$ & & 1.443 & $\begin{array}{l}382.061 \\
229.411\end{array}$ & $\begin{array}{l}76.901 \\
17.494\end{array}$ & $\begin{array}{l}199.618 \\
66.417\end{array}$ & $\begin{array}{l}939.917 \\
20815\end{array}$ & (3) & \\
\hline & Indústria de alinenonse em geral & 853.753 & 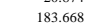 & 289.959 & 139.322 & 218 & 1.381 & & 202.281 & 200.095 & 161.068 & 263 & 168 \\
\hline & Indústrias diversas & & 79.227 & & 29. & 391 & 247 & & 80.813 & 49.817 & 25.566 & & 435 \\
\hline & is de utilidade pública & 171.664 & 2.701 & & & & 95 & & & 52.042 & 1.099 & & 320 \\
\hline 22 & Construáác c & & $\begin{array}{l}1.591 .690 \\
.670909-200\end{array}$ & 1.203 .524 & & 10.662 & 4.858 & & 1.759.382 & & & 69.778 & \\
\hline & $\begin{array}{l}\text { Comercio } \\
\text { Transpotere }\end{array}$ & $\begin{array}{r}2.312 .9636 \\
641066\end{array}$ & $\begin{array}{l}4.677 .991 \\
1.545 .971\end{array}$ & $\begin{array}{r}1.1773 .640 \\
298.360\end{array}$ & $\begin{array}{l}904 \\
107\end{array}$ & & 1.000 & $\begin{array}{l}\text { 2.148.7270 } \\
\text { 3779 } 9775\end{array}$ & 5.006 .722 & $\begin{array}{l}1.194 .8844 \\
3025280\end{array}$ & $\begin{array}{r}956.5797 \\
16888363\end{array}$ & 2733 & 6.995 \\
\hline & Comunicace & & 1.677 & & & & & & & (3) & $=5023$ & (3) & \\
\hline & Insti & 548.120 & 6.881 & & & & 4 & & & & & & 666 \\
\hline & S fammlilias & 3.642.481 & 2.999.025 & 1.632. 258 & 1.005 .820 & 1.252 & 6.464 & 5 & 1 & 1.618.810 & 1.080.460 & 604 & \\
\hline 28 & empresas & 1.410 .830 & 471.594 & 393.752 & 189.173 & & 1.150 & & & & 168.055 & & 038 \\
\hline & Alu & & & 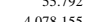 & & & & & & & & & \\
\hline 31 & & & & & & & & & & & & & \\
\hline & TOTAI & 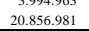 & $\begin{array}{l}1.5820 .018 \\
19.889\end{array}$ & $\begin{array}{r}8.938 .933 \\
.238 .998\end{array}$ & $\begin{array}{r}100.6984 \\
1.969 .182\end{array}$ & $\begin{array}{r}1.828 \\
14.011\end{array}$ & 69.339 & $\begin{array}{r}4.1 .080 .8393 \\
20.530 .292\end{array}$ & . .7994 .1222 & 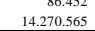 & 685.6643 & 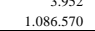 & $\begin{array}{l}1.046 \\
51.508 \\
\end{array}$ \\
\hline
\end{tabular}


ANEXO X - Número de pessoas ocupadas por tempo de serviço - 1990/1992.

\begin{tabular}{|c|c|c|c|c|c|c|c|c|c|c|c|c|c|}
\hline \multirow{2}{*}{ Set } & Setor & \multirow[b]{2}{*}{ menos de 1 ano } & \multirow{2}{*}{\multicolumn{3}{|c|}{$\begin{array}{l}1990 \\
0 \text { anos } \\
0\end{array} 1$ a 29 anos }} & \multirow{2}{*}{\multicolumn{3}{|c|}{30 a 39 anos 10 anos ou mais menos de 1 ano }} & \multicolumn{5}{|c|}{ 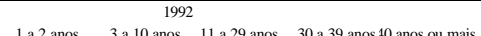 } \\
\hline & & & & & $\frac{11 \text { a } 29 \text { anos }}{3.30170}$ & & & & $\frac{1 \mathrm{a} 2 \text { anos }}{2007}$ & $\frac{3 \mathrm{a} 10 \text { anos }}{5621333}$ & $\frac{11 \mathrm{a} 29 \text { anos }}{3827999}$ & $\frac{30 \mathrm{a} 39 \text { anos } 50 \mathrm{at}}{723986}$ & $\begin{array}{cc}\text { nos ou mais } \\
253006\end{array}$ \\
\hline 2 & $\begin{array}{l}\text { Agropecurána } \\
\text { Extrativa mineral (exceto combustíveis) }\end{array}$ & & & & & & 191.139 & $\begin{array}{l}2.326 .036 \\
7490\end{array}$ & & 5.621 .333 & & & \\
\hline & 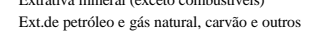 & $\begin{array}{l}115.0942 \\
5272\end{array}$ & $\begin{array}{r}6.1881 \\
3.409\end{array}$ & $\begin{array}{l}8.103 \\
17.785\end{array}$ & $\begin{array}{l}3.2914 \\
7.049\end{array}$ & $\begin{array}{l}4.1 .88 \\
585\end{array}$ & 1.018 & 74.014 & 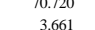 & $\begin{array}{l}76.480 \\
1354\end{array}$ & $\begin{array}{l}33.845 \\
8.579\end{array}$ & 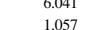 & \\
\hline 4 & 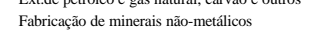 & 198.701 & 117.126 & 162.903 & 61.127 & 4.082 & 1.760 & $\begin{array}{r}14.047 .704 \\
\end{array}$ & 137.090 & $\begin{array}{c}13.049 \\
148.915\end{array}$ & 47.097 & 2.092 & 1.302 \\
\hline 5 & Siderurgia, met. não-ferrosos e out.prod. & 221.426 & 193.922 & 328.061 & 157.142 & 10.707 & 4.642 & 168.273 & 215.155 & 289.681 & 108.143 & 5.951 & 3.298 \\
\hline 6 & nutencĩo de mág & & & 195.318 & 87.086 & 4.064 & & 117.509 & 104.231 & 154.759 & & 4.989 & \\
\hline 7 & de ap. & & $\begin{array}{l}112.732 \\
0.1470\end{array}$ & 128.684 & 41.963 & 2.104 & & 59.033 & & 83.859 & 33.206 & & 167 \\
\hline 8 & 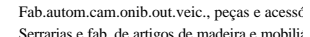 & & $\begin{array}{r}91.470 \\
17559\end{array}$ & $\begin{array}{l}157.153 \\
27443\end{array}$ & $\begin{array}{l}74.803 \\
13263\end{array}$ & $\begin{array}{r}2.352 \\
21.126\end{array}$ & $\begin{array}{r}839 \\
18365\end{array}$ & $\begin{array}{c}56.116 \\
102466\end{array}$ & $\begin{array}{c}76.511 \\
213063\end{array}$ & 127.976 & 40 & 57 & \\
\hline $\begin{array}{c}9 \\
10\end{array}$ & 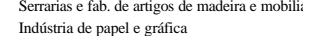 & $\begin{array}{l}258.244 \\
125713\end{array}$ & 121.152 359 & $\begin{array}{l}274.443 \\
135998\end{array}$ & (34.263 138.881 & $\begin{array}{l}21.126 \\
3015\end{array}$ & $\begin{array}{l}13.365 \\
840\end{array}$ & $\begin{array}{l}192.446 \\
104347\end{array}$ & 213.063 2030 & 21476522 & $\begin{array}{l}9.8994 \\
53084\end{array}$ & 17.2912 & 12.883 \\
\hline & Listria da borracha & 18.600 & $\begin{array}{l}191.152 \\
19.631\end{array}$ & 29.362 & $\begin{array}{l}6.8881 \\
13.654\end{array}$ & $\begin{array}{l}3.015 \\
862\end{array}$ & 491 & 14.897 & $\begin{array}{l}130.330 \\
26.431\end{array}$ & $\begin{array}{l}174.624 \\
26.247\end{array}$ & 6.8.884 5894 & ${ }_{444}^{2.47}$ & 1.313 \\
\hline 12 & . Elem. químicos $\mathrm{n}$ : & 71.1 & 438 & 226 & 65 & 4.097 & & 69.276 & & & & 2.952 & \\
\hline & no de & & & & & & - & & & & 15.204 & & \\
\hline & & & & & & 852 & & & & & & 4.899 & \\
\hline & Indústria & 60.231 & & & & & & & & 60.660 & 12.666 & & \\
\hline 16 & ústria texxil & 104.256 & 105.577 & 126.637 & 58.001 & 7.931 & 5.598 & 52.781 & 99.215 & 143.613 & 51.469 & 9.395 & 3.527 \\
\hline & gos dc & & & & 307 & 64 & 48.278 & & & & & T & 48.282 \\
\hline & gos de couro & & & & 27.588 & 1.969 & 2.045 & 129.382 & 66 & 8 & & 819 & 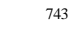 \\
\hline & lústriis & & 357 & 430.653 & 154. & 12.156 & & 415. & 46 & 461.048 & & 15.613 & 3.729 \\
\hline & & & & & & & & & & & & & 1.937 \\
\hline & s de utilidade pública & & & $\begin{array}{l}116.850 \\
078357\end{array}$ & & & 942 & & & & & & \\
\hline & $\begin{array}{l}\text { Construçăa civil } \\
\text { Comécio }\end{array}$ & $\begin{array}{l}1.666 .332 \\
1.79294\end{array}$ & $\begin{array}{r}693.717 \\
1777306\end{array}$ & $\begin{array}{r}978.357 \\
2791443\end{array}$ & $\begin{array}{r}523.042 \\
1080205\end{array}$ & 52.034 & 22.517 & $\begin{array}{l}1.342 .190 \\
1.66570\end{array}$ & $\begin{array}{r}758.534 \\
2130863\end{array}$ & $\begin{array}{r}862 \\
285 \\
285\end{array}$ & $\begin{array}{l}414.050 \\
865798\end{array}$ & 676 & $\begin{array}{l}18.040 \\
87.163\end{array}$ \\
\hline & Comérci & 1.792.194 292731 & $\begin{array}{l}1.772 .306 \\
323.192\end{array}$ & $\begin{array}{r}2.791 .434 \\
765.870\end{array}$ & $\begin{array}{l}1.108 .2205 \\
615293\end{array}$ & $\begin{array}{l}113.569 \\
53.095\end{array}$ & $\begin{array}{l}4.1 .992 \\
28.118\end{array}$ & $\begin{array}{l}1.666 .70 \\
173.163\end{array}$ & $\begin{array}{r}2.1 .100 .836 \\
439.916\end{array}$ & $\begin{array}{r}2.8533 .223 \\
940.388\end{array}$ & $\begin{array}{l}867.498 \\
437.160\end{array}$ & $\begin{array}{l}123.210 \\
49.673\end{array}$ & 87.163 \\
\hline & Iransporte & 22.8 & $\begin{array}{r}352.192 \\
19.348\end{array}$ & & $\begin{array}{l}615.293 \\
69.446\end{array}$ & $\begin{array}{l}3.6987 \\
2.687\end{array}$ & $\begin{array}{l}28.118 \\
289\end{array}$ & & & & & & \\
\hline & & & & & & & & & & & & & \\
\hline & & & & & & & & & & & & & 29.240 \\
\hline & & & 391. & & & & & & & & & & \\
\hline & & & & & & & & & & & & & \\
\hline 30 & & & 891.019 & 2.424.246 & & & 92 & 889.835 & 60 & 75 & 111 & 51 & 68 \\
\hline 31 & $\begin{array}{l}\text { Servicos privados não-mercantis } \\
\text { ThTA }\end{array}$ & $\begin{array}{r}2.023 .968 \\
1.583235\end{array}$ & 887.458 & $\begin{array}{r}947.709 \\
\end{array}$ & 232.877 & 15.075 & $\begin{array}{r}9.014 \\
340355\end{array}$ & $\begin{array}{l}1.799 .392 \\
1076801\end{array}$ & $\begin{array}{r}1.363 .145 \\
1305795\end{array}$ & $\begin{array}{l}1.189 .580 \\
0.62070\end{array}$ & 271.122 & $\begin{array}{r}25.563 \\
34669\end{array}$ & 8.298 \\
\hline
\end{tabular}


ANEXO X - Número de pessoas ocupadas por tempo de serviço - 1993/1995.

\begin{tabular}{|c|c|c|c|c|c|c|c|c|c|c|c|c|c|}
\hline \multirow{2}{*}{\multicolumn{2}{|c|}{ Setor }} & \multirow[b]{2}{*}{ menos de 1 ano } & \multirow{2}{*}{\multicolumn{3}{|c|}{$\begin{array}{l}1993 \\
0 \text { anos } \\
11 \text { a } 29 \text { anos }\end{array}$}} & \multirow{2}{*}{\multicolumn{3}{|c|}{30 a 39 anos 10 anos ou mais menos de 1 ano }} & \multicolumn{5}{|c|}{1995} \\
\hline & & & & & & & & & $1 \mathrm{a} 2$ anos & $\frac{3 \mathrm{a} 10 \text { anos }}{5161010}$ & $\frac{11 \text { a } 29 \text { anos }}{2704801}$ & 30 a 39 anos 50 : & sou mais \\
\hline 1 & Agropecuária & 2.252.762 & 2.634 .145 & 5.681 .679 & 4.069 .787 & 594.980 & 338.247 & 3.215.042 & & & & & \\
\hline & $\begin{array}{l}\text { Extrativa mineral (exceto combustivieis) } \\
\text { Furros. }\end{array}$ & 79.830 & $\begin{array}{c}65.153 \\
2000\end{array}$ & 91.156 & 27.674 & & 4.387 & 33.599 & 37.737 & 98.180 & 60.493 & 291 & \\
\hline & 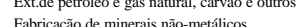 & $\begin{array}{r}3.104 \\
126.588\end{array}$ & $\begin{array}{l}2.2 .400 \\
12347\end{array}$ & 16.671 & $\begin{array}{l}1.0232 \\
5.279\end{array}$ & 2996 & 2227 & 21946 & $\begin{array}{l}7.148 \\
059099\end{array}$ & $\begin{array}{l}9.341 \\
151824\end{array}$ & 13.888 & 97 & \\
\hline & 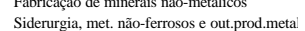 & 1466.775 & 157.4583 & $\begin{array}{l}162.363 \\
303.869\end{array}$ & 135.858 & 12307 & 1908 & $\begin{array}{l}1794.46 \\
94087\end{array}$ & 1499854 & 3339097 & $\begin{array}{l}63.590 \\
172337\end{array}$ & & \\
\hline & 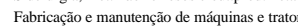 & & 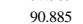 & & & 然. & $1.42 \mathrm{C}$ & & & & & & 1.93 \\
\hline & Fab.de ap.e equip.de n & & 74 & 102.133 & & 2.662 & & & & & & & \\
\hline & bautom.cam.onit & 62.403 & & 129.518 & & & & & & & & & \\
\hline & Serrarias e fab. de artigos de ma & 192.491 & 215.006 & 263.991 & 119.086 & 15.086 & 12.840 & 167.428 & 138.199 & 295.779 & 157.799 & 43.941 & 39.953 \\
\hline & Indústria de papel e gráfic. & & & & & 3.206 & 466 & 103.551 & 104.693 & 162.824 & 60.144 & 2.289 & \\
\hline & ústria da borracha & & 20.820 & 29.075 & & & & 9.731 & 15.767 & 26.232 & 14.515 & 655 & \\
\hline 12 & io-perroq.c & 46.618 & 61.658 & 95.870 & & 1.250 & & 84 & & 125.579 & & 1.134 & \\
\hline & nod & & & & & 548 & & & & 20.239 & & 667 & \\
\hline & & & & & & 294 & 476 & & & 45.864 & & 30 & \\
\hline & $\begin{array}{l}\text { Indústria de transformaçăo de material plasticic } \\
\text { Indútstiatéxil }\end{array}$ & $\begin{array}{l}45.063 \\
565757\end{array}$ & 55.146 & $\begin{array}{r}62.483 \\
147758\end{array}$ & $\begin{array}{r}5.933 \\
4864\end{array}$ & $\begin{array}{l}2.075 \\
5965\end{array}$ & & 53.106 & $\begin{array}{l}48.365 \\
35670\end{array}$ & $\begin{aligned} 52.738 \\
133308\end{aligned}$ & $\begin{array}{r}9.101 \\
7461\end{array}$ & 1.590 & \\
\hline & $\begin{array}{l}\text { Indúustria têxtil } \\
\text { Fabricaço de at }\end{array}$ & $\begin{array}{l}56.457 \\
285567\end{array}$ & $\begin{array}{r}94.026 \\
341775\end{array}$ & $\begin{array}{l}147.158 \\
53.645\end{array}$ & $\begin{array}{l}48.464 \\
380514\end{array}$ & $\begin{array}{r}5965 \\
75230\end{array}$ & $\begin{array}{r}3.830 \\
3.8369\end{array}$ & 301498 & $\begin{array}{l}35.670 \\
277976\end{array}$ & 5183.3040 & 389.1677 & $\begin{array}{l}1.2 .10 \\
11862\end{array}$ & 13.453 \\
\hline 18 & $\begin{array}{l}\text { le artigos de couro e pele: } \\
\text { e }\end{array}$ & 137.323 & 129.431 & 130.752 & $\begin{array}{l}29.059 \\
29.059\end{array}$ & $\begin{array}{l}1.230 \\
844\end{array}$ & 691 & 106.389 & $\begin{array}{l}27.976 \\
61.424\end{array}$ & 0.097 & 31.293 & 670 & 24.019 \\
\hline & lústri & & & & & 15.704 & 98 & & & 0 & & 77.273 & 34 \\
\hline & & & & & & & 8 & & & & & & 1.135 \\
\hline & s de utilidade pública & & & & & & 488 & & & & & & \\
\hline & $\begin{array}{l}\text { Construçăác civil } \\
\text { Comério }\end{array}$ & $\begin{array}{l}1.118 .801 \\
109965\end{array}$ & $\begin{array}{l}770.742 \\
1.743324\end{array}$ & $\begin{array}{l}1.038 .046 \\
3.194447\end{array}$ & 529.554 & 69.014 & 24.143 & $\begin{array}{l}1.138 .373 \\
1771.141\end{array}$ & 524,364 & $\begin{array}{l}1.015 .761 \\
3.13247\end{array}$ & 653.188 & 50.134 & 47.581 \\
\hline & Comércio & $\begin{array}{l}1.919 .9655 \\
392.247\end{array}$ & $\begin{array}{l}1.743 .334 \\
30386\end{array}$ & $\begin{array}{l}3.1499 .474 \\
751.893\end{array}$ & $\begin{array}{l}1.289 .5916 \\
539487\end{array}$ & $\begin{array}{l}121.466 \\
46.686\end{array}$ & $\begin{array}{l}18.905 \\
3.501\end{array}$ & $\begin{array}{l}1.7711 .141 \\
286.970\end{array}$ & $\begin{array}{l}2.122 .827 \\
44262\end{array}$ & $\begin{array}{r}3.136 .247 \\
758251\end{array}$ & $\begin{array}{l}1.566 .320 \\
645.287\end{array}$ & $\begin{array}{l}278.730 \\
2771\end{array}$ & $\begin{array}{l}150.35 \\
130.358\end{array}$ \\
\hline 25 & & & & & & $\begin{array}{l}4.060 \\
1.818\end{array}$ & & 280.9010 & 年11.202 & 55.019 & & $\begin{array}{l}2.171 \\
1.681 \\
\end{array}$ & 150.538 \\
\hline 26 & & & & & & & 2.4 & & & & & & \\
\hline & 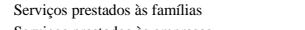 & 1.655 & 1.991 .101 & 2.851 & & 91. & & & & & & & 39.926 \\
\hline 28 & às empres & 10.043 & 469.870 & 582.970 & 208.906 & 22.749 & 5.162 & 505.260 & 312.802 & & 313.272 & 143.295 & 199 \\
\hline & $\begin{array}{l}\text { Aluguel le imóveis } \\
\text { Administraço pública }\end{array}$ & 21 & $\begin{array}{l}10 \\
68\end{array}$ & $\begin{array}{l}68.6212 \\
229298\end{array}$ & $\begin{array}{l}51.5699 \\
885089\end{array}$ & $\begin{aligned} 5.947 \\
89284\end{aligned}$ & $\begin{array}{l}79 \\
50\end{array}$ & 90 & 63 & $\begin{array}{l}102.462 \\
157939\end{array}$ & 29 & 13 & .791 \\
\hline 31 & $\begin{array}{l}\text { vados não-mercantis } \\
\text { vant }\end{array}$ & 1.727 .580 & 1.280 .511 & 1.447 .488 & 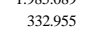 & $\begin{array}{l}39.628 \\
30.28\end{array}$ & 10.6 & $\begin{array}{r}2.049 .938 \\
2.30\end{array}$ & 1.475 .573 & $\begin{array}{l}1.501 .452 \\
\end{array}$ & $\begin{array}{l}1.95 .5271 \\
322.098\end{array}$ & 31.518 & \\
\hline & TOTAL & 12.310 .777 & 12.440 .561 & 21.429 .802 & 11.695 .527 & 1.242.781 & 510.852 & 13.729 .242 & 11.540 .925 & 20.813 .621 & 11.421 .461 & 2.992.058 & 728.792 \\
\hline
\end{tabular}


ANEXO X - Número de pessoas ocupadas por tempo de serviço - 1996 -1997.

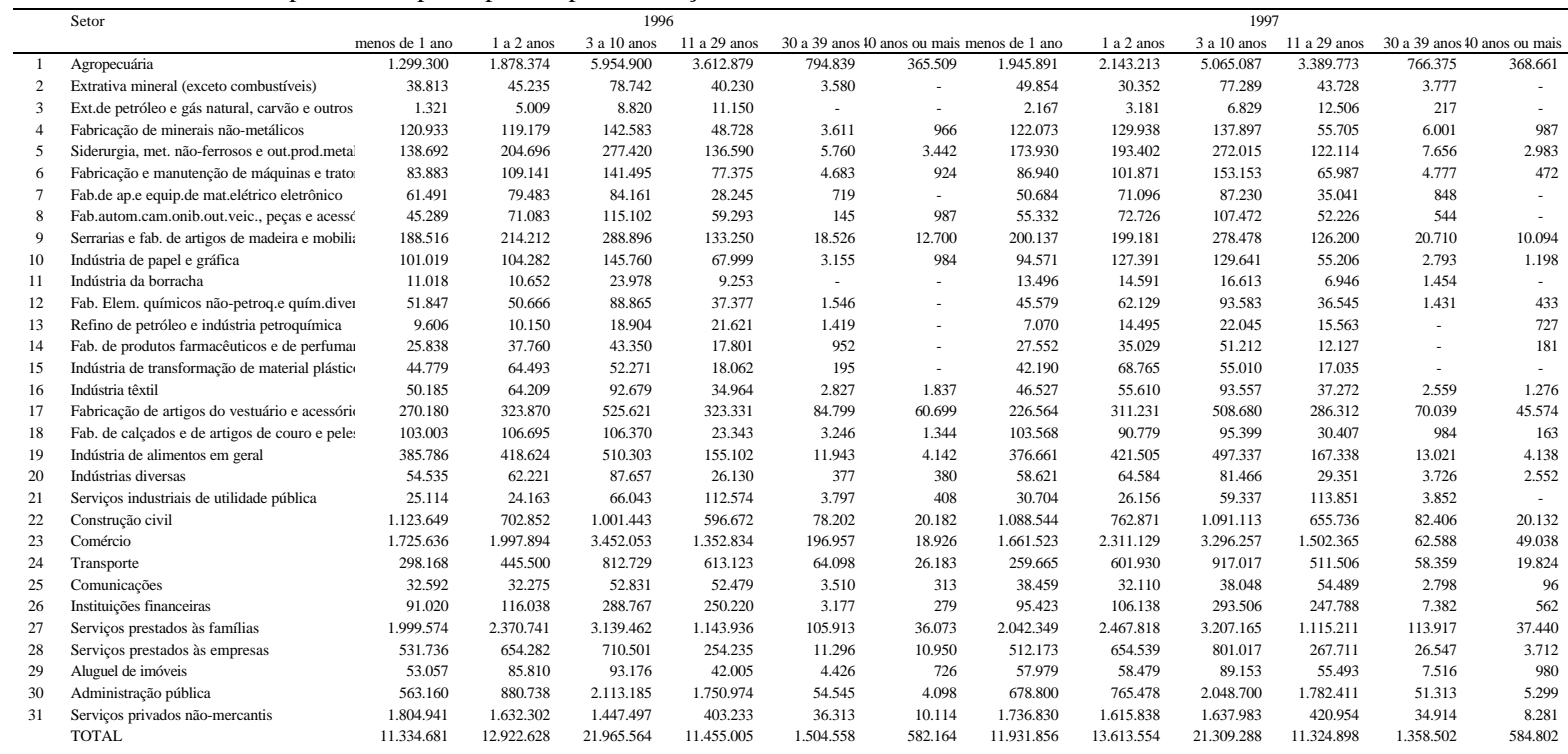


ANEXO X - Número de pessoas ocupadas por tempo de serviço - 1998 -1999.

\begin{tabular}{|c|c|c|c|c|c|c|c|c|c|c|c|c|c|}
\hline & \multirow[t]{2}{*}{ Setor } & \multirow{2}{*}{ menos de 1 ano } & \multicolumn{3}{|c|}{1998} & \multirow{2}{*}{\multicolumn{3}{|c|}{30 a 39 anos to anos ou mais menos de 1 ano }} & \multicolumn{5}{|c|}{1999} \\
\hline 1 & & & $\frac{12 \mathrm{a} \text { anos }}{2637656}$ & $\frac{3 \text { a } 10 \text { anos }}{4773448}$ & 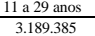 & & & & $\frac{1 \mathrm{a} 2 \text { anos }}{2.35 .19}$ & $\frac{3 \text { a } 10 \text { anos }}{4811555}$ & $\frac{11 \mathrm{a} 29 \text { anos }}{4311225}$ & $\frac{30 \mathrm{a} 39 \text { anos th }}{588.358}$ & 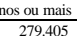 \\
\hline 2 & Extrativa mineral (exceto co & 38.833 & 58.781 & 82.596 & 25.793 & 822 & 875 & 38.497 & 40.170 & 70.106 & 38.183 & 2.643 & \\
\hline & Ext.de petróleo e gás natural, carvão e outros & 1.163 & 3.057 & 7.320 & 15.660 & & & 3.896 & 5.117 & 8.782 & 19.205 & & \\
\hline 4 & Fabricaçăo de minerais não-metalili & 103.557 & 114.245 & 130.076 & 60.326 & 4.043 & 1.454 & 122.404 & 106.540 & 156.755 & 43.110 & 1.404 & \\
\hline 5 & Siderurgia, met. não-ferrosos e o & 137.844 & 198.265 & 299.965 & 137.438 & 11.245 & 6.744 & 138.762 & 181.928 & 266.481 & 128.608 & 9.384 & 3.238 \\
\hline & 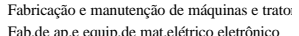 & $\begin{array}{l}74.636 \\
46784\end{array}$ & 122.020 & 130.303 & 58.885 & 1.469 & 888 & 69.764 & 93.478 & 144.765 & 67.907 & 4.163 & \\
\hline $\begin{array}{l}7 \\
8\end{array}$ & 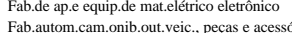 & $\begin{array}{l}46.784 \\
32718\end{array}$ & 63.435 & $\begin{array}{r}80.533 \\
103461\end{array}$ & $\begin{array}{l}38.628 \\
53379\end{array}$ & $\begin{array}{l}1.321 \\
4656\end{array}$ & & 45.044 & $\begin{array}{l}45.560 \\
62855\end{array}$ & 90.180 & 26.463 & ${ }_{152}^{626}$ & 627 \\
\hline & 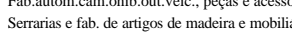 & $\begin{array}{l}32.718 \\
155.746\end{array}$ & $\begin{array}{l}63.176 \\
198.936\end{array}$ & 274.9615 & $\begin{aligned} 33.979 \\
118.352\end{aligned}$ & 25.509 & 15.082 & $\begin{array}{l}43.572 \\
177.134\end{array}$ & $\begin{array}{l}62.855 \\
189.006\end{array}$ & 2710.455 17.453 & $\begin{array}{l}60.422 \\
135.702\end{array}$ & $\begin{array}{r}1.1992 \\
20.489\end{array}$ & $\begin{array}{r}885 \\
14.216\end{array}$ \\
\hline 10 & Indústria de papel e gráfica & 85.854 & 120.819 & 149.304 & 50.730 & 3.068 & 625 & 98.118 & 110.951 & 154.040 & 49.213 & 3.591 & 1.387 \\
\hline 11 & Indústria da borracha & 10.150 & 10.616 & 16.139 & & 640 & 640 & 8.344 & 9.042 & 21.771 & 6.997 & & 446 \\
\hline & & & & & & 2.329 & & 30.112 & & & & 2.386 & \\
\hline & Refino de & & & & & & - & 6.605 & & 16.356 & & 41 & - \\
\hline $\begin{array}{l}14 \\
15\end{array}$ & $\begin{array}{l}\text { Fab. de pre } \\
\text { Indústria d }\end{array}$ & $\begin{array}{l}24.661 \\
43681\end{array}$ & $\begin{array}{l}36.972 \\
51.25\end{array}$ & $\begin{array}{l}49.304 \\
6.833 \\
6\end{array}$ & 17.463 & & & 29.610 & & $\begin{array}{l}40.151 \\
72647\end{array}$ & $\begin{array}{l}13.456 \\
23246\end{array}$ & 1.322 & \\
\hline 16 & $\begin{array}{l}\text { Indusustriale tran } \\
\text { Industria textil }\end{array}$ & $\begin{array}{l}43.681 \\
35.571\end{array}$ & $\begin{array}{l}51.025 \\
52.678\end{array}$ & $\begin{array}{r}68.033 \\
101.291\end{array}$ & $\begin{array}{l}1.9151 \\
37.461\end{array}$ & $\begin{array}{l}2.340 \\
2.329\end{array}$ & $\begin{array}{r}8.60 \\
1.669\end{array}$ & $\begin{array}{l}42.99 \\
43.729\end{array}$ & $\begin{array}{l}6.6311 \\
61.250\end{array}$ & $\begin{array}{l}72.647 \\
9.4019\end{array}$ & 3.2.246 246 & $\begin{array}{r}868 \\
1655\end{array}$ & $\begin{array}{r}728 \\
1521\end{array}$ \\
\hline & Fabricacąâo de artigos do vestuár & 216.837 & 322.491 & 478.804 & 284.684 & 62.966 & 43.918 & 236.995 & $\begin{array}{l}287.158 \\
2878\end{array}$ & 534.939 & 290.686 & 64.181 & 37.241 \\
\hline 18 & Fab. de & 99.388 & 99.793 & 105.739 & 28.045 & 818 & 718 & 104.680 & 4 & & 33.623 & 73 & 251 \\
\hline & Indu & 343.078 & & 527.357 & & 14.263 & 02 & 336.108 & & & & & 2.795 \\
\hline & $\begin{array}{l}\text { Indústrii } \\
\text { Sercicos }\end{array}$ & & & & & & 1.814 & & & 105.083 & & & 981 \\
\hline & $\begin{array}{l}\text { Serviços industriais de utilidade püblica } \\
\text { Construço civil }\end{array}$ & $\begin{array}{r}30.491 \\
1.289 .514\end{array}$ & $\begin{array}{r}33.908 \\
820.613\end{array}$ & $\begin{array}{r}63.052 \\
1.163 .714\end{array}$ & $\begin{array}{l}105.785 \\
650.671\end{array}$ & $\begin{array}{l}4.633 \\
89.837\end{array}$ & $\begin{array}{r}132 \\
21650\end{array}$ & $\begin{array}{r}25.072 \\
1.002612\end{array}$ & $\begin{array}{l}266.889 \\
868.243\end{array}$ & $\begin{array}{r}66.3216 \\
1.242 .091\end{array}$ & $\begin{array}{l}92.868 \\
621.378\end{array}$ & $\begin{array}{r}4.356 \\
8453\end{array}$ & 20.023 \\
\hline & $\begin{array}{l}\text { Comérćcio civil } \\
\text { lat }\end{array}$ & 1.289 .314 & $\begin{array}{r}820.013 \\
2.127 .682\end{array}$ & $\begin{array}{l}1.163 .144 \\
3.783 .302\end{array}$ & $\begin{array}{l}6350.6811 \\
1.57823\end{array}$ & 89.837 & 21.650 & 1.002.612 & 868.243 & 1.242 .091 & 691.378 & 84.433 & \\
\hline & Tran & 355.687 & 641.216 & 881.062 & 480.8 & 40.674 & 14.382 & $\begin{array}{l}1.01 .1401 \\
346.015\end{array}$ & 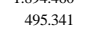 & 995.844 & $\begin{array}{l}1.74 .6039 \\
418.549\end{array}$ & 117.677 & 10.273 \\
\hline 25 & & & & & & & 365 & 2 & & & & 28 & \\
\hline 26 & & & 116.136 & 234.419 & & & & & & 4 & 88 & 4 & $1 / 2$ \\
\hline & famililas & 1.914.289 & 2.507 .769 & 3.553.875 & 1.165.924 & 108.811 & 37.232 & .878 .955 & 2.471.230 & 3.713.816 & 1.236.546 & 118.189 & \\
\hline 28 & presesas & & 741. & 9078 . & & 21.4 & 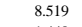 & & & & & & 5.840 \\
\hline & & & & & & & & & & & & & \\
\hline 30 & & & & & & 56.569 & 5.339 & & 0 & & 1.940 .385 & 1 & 4.763 \\
\hline & $\begin{array}{l}\text { Servico: } \\
\text { TTtal }\end{array}$ & $\begin{array}{l}1.584 .973 \\
11463747\end{array}$ & $\begin{array}{r}1.628 .924 \\
13456282\end{array}$ & $\begin{array}{r}1.698 .519 \\
21972955\end{array}$ & $\begin{array}{r}458.204 \\
11353.310\end{array}$ & $\begin{array}{r}39.314 \\
18329\end{array}$ & $\begin{array}{c}14.966 \\
433077\end{array}$ & $\begin{array}{l}1.675 .002 \\
11578657\end{array}$ & $\begin{array}{r}1.625 .141 \\
13501534\end{array}$ & $\begin{array}{l}1.782 .756 \\
2069020\end{array}$ & $\begin{array}{l}454.698 \\
458366\end{array}$ & $\begin{array}{l}42.721 \\
3329094\end{array}$ & 12.283 \\
\hline
\end{tabular}




\begin{tabular}{|c|c|c|c|c|c|c|c|c|c|c|c|c|c|}
\hline & Setor & \multirow[b]{2}{*}{ atél 14 horas } & \multicolumn{5}{|c|}{1990} & \multirow{2}{*}{\multicolumn{6}{|c|}{$\begin{array}{lll} & 1992 \\
\text { até } 14 \text { horas } & 15 \text { a } 39 \text { horas } & 40 \text { a } 44 \text { horas }\end{array}$}} \\
\hline & & & a d foras & 40 a 44 horas & 45 a 48 horas & & I nāo aplic. & & & & & & \\
\hline & Agropecuária & & 2.869 .198 & 4.673 .817 & 2.481 .333 & 4.736 .482 & & 1.238 .778 & 4.899 .361 & & 1.466.163 & 4.399 .916 & 50.4 \\
\hline & 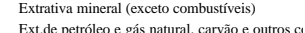 & - & $\begin{array}{r}29.593 \\
5480\end{array}$ & $\begin{array}{l}124.293 \\
18728\end{array}$ & $\begin{array}{r}69.208 \\
4982\end{array}$ & 78.106 & - & 7.758 & 46.133 & 98.304 & 48.272 & 60.633 & \\
\hline & 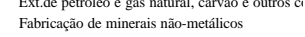 & & $\begin{array}{r}5.480 \\
55.903\end{array}$ & $\begin{array}{l}18.128 \\
255.082\end{array}$ & $\begin{array}{r}4.982 \\
121.272\end{array}$ & $\begin{array}{r}4.9100 \\
113.42\end{array}$ & - & 2.206 & $\begin{array}{l}1.433 \\
40.751\end{array}$ & $\begin{array}{r}199686 \\
216.253\end{array}$ & $\begin{array}{r}4.275 \\
124.153\end{array}$ & $\begin{array}{r}7.0003 \\
95.438\end{array}$ & \\
\hline 5 & Siderurgia, met. năo-ferrosose e out.prod.metalu & 605 & 59.359 & 562.450 & 207.516 & ${ }_{85.971} 19.42$ & $x_{-1}$ & 3.319 & 60.515 & 413.694 & 212.353 & & 1.415 \\
\hline & Fabricąấa e manutençấ de máquinas e tratorere & & 13.388 & 370.725 & 89.548 & $\begin{array}{l}83.971 \\
46.339\end{array}$ & & . & 22.202 & $\begin{array}{l}41.0944 \\
252.422\end{array}$ & 212.0393 & 75.354 & \\
\hline 7 & Fab.de ap.e equip.de mat.elértico eletrônico & 236 & 14.968 & 260.234 & 67.965 & 197 & & 1.000 & 19.531 & 160.602 & 48.205 & 24.262 & \\
\hline 8 & Fab.autom.cam.onib.out.veic., peças e acessóri & 728 & & & 110.484 & 30.608 & & & 7.818 & 206.349 & 75.981 & & \\
\hline & Serrarias e fab. de artigos de madeira e mobiliár & 4.892 & 91.191 & 389.983 & 206.591 & 185.772 & 571 & 5.455 & 82.278 & 317.394 & 168.305 & 185.365 & 2.004 \\
\hline & Indústria de papel e gráfica & 2.165 & 49.643 & 269.300 & 78.357 & 58.734 & - & 2.899 & 52.855 & 235.771 & 92.050 & 55.625 & \\
\hline & Indístria da borracha & & 1.191 & 51.021 & $\begin{array}{l}21.410 \\
77202\end{array}$ & $\begin{array}{r}8.978 \\
3.510\end{array}$ & - & & 2.137 & 41.304 & 24.462 & $\begin{array}{r}6.997 \\
52905\end{array}$ & \\
\hline${ }_{13}^{12}$ & 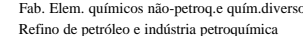 & 1.086 & $\begin{array}{l}19.110 \\
6.612\end{array}$ & $\begin{array}{l}161.620 \\
62.004\end{array}$ & $\begin{array}{l}72.242 \\
12.662 \\
7\end{array}$ & $\begin{array}{l}35.142 \\
6.322\end{array}$ & : & 1.177 & $\begin{array}{l}20.555 \\
6.581\end{array}$ & $\begin{array}{r}126.951 \\
5.086\end{array}$ & $\begin{array}{l}67.892 \\
13.499\end{array}$ & $\begin{array}{c}52.955 \\
6.744\end{array}$ & \\
\hline & Fab. de produtos farmacêuticos e de perfumarici & 323 & $\begin{array}{l}6.062 \\
5.846\end{array}$ & 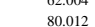 & $\begin{array}{l}12.022 \\
18.587\end{array}$ & & - & 1.099 & $\begin{array}{l}0.081 \\
11.080\end{array}$ & & & & \\
\hline 15 & Indústria de transformaçăo de material plasticico & 789 & $\begin{array}{l}5.840 \\
8.006\end{array}$ & $\begin{aligned} 80.012 \\
129.223\end{aligned}$ & $\begin{array}{l}18.587 \\
41.703\end{array}$ & $\begin{array}{l}13.932 \\
12.679\end{array}$ & & & 6.698 & $\begin{array}{r}2.21111 \\
103.006\end{array}$ & $\begin{array}{l}28.260 \\
34.652\end{array}$ & 22.407 & 1.438 \\
\hline 16 & Indústria textil & 5.861 & 64.650 & 214.471 & 74.681 & 47.565 & 773 & 7.714 & 69.823 & 158.656 & 79.922 & 43.885 & \\
\hline & Fabricąẵo de artigos do vestuário e acessórios & 53.681 & 614.078 & 575.176 & 188.767 & 245.356 & 1.942 & 87.532 & 544.740 & 433.170 & 192.211 & 240.120 & 1.126 \\
\hline & Fab. de calçados e de artigos de couro e peles & 1.539 & 30.212 & 304.836 & 61.138 & 35.975 & & 2.935 & 27.942 & 277.569 & 48.725 & 49.009 & 120 \\
\hline & tos em geral & 11.614 & 132.255 & & 363.367 & 335.938 & - & 49.473 & 220.865 & 479.092 & 377.184 & 385.753 & 2.333 \\
\hline 20 & $\begin{array}{l}\text { Indústrias diversas } \\
\text { Sevios }\end{array}$ & 3.642 & $\begin{array}{l}43.910 \\
3.0955\end{array}$ & $\begin{array}{l}144.177 \\
235572\end{array}$ & & $\begin{array}{l}24.637 \\
20556\end{array}$ & - & 8.867 & 73.310 & & 52.047 & 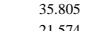 & \\
\hline & $\begin{array}{l}\text { Serviogos industriais de utilidade püblica } \\
\text { Construcaco civil }\end{array}$ & $\begin{array}{l}1.1665 \\
5.254\end{array}$ & $\begin{array}{r}30.85 \\
181.553\end{array}$ & $\begin{array}{r}235.752 \\
1.868 .058\end{array}$ & $\begin{array}{r}30.072 \\
967.286\end{array}$ & $\begin{array}{r}25.956 \\
910.565\end{array}$ & 3.283 & $\begin{array}{r}237 \\
42.130\end{array}$ & $\begin{array}{l}36.435 \\
197.585\end{array}$ & $\begin{array}{l}1988.483 \\
1.474 .841\end{array}$ & $\begin{array}{r}34.0 .41 \\
931.417\end{array}$ & $\begin{array}{r}21.174 \\
799.244\end{array}$ & 5.983 \\
\hline & $\begin{array}{l}\text { Construçáio civil } \\
\text { Comério }\end{array}$ & 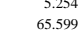 & $\begin{array}{l}181.533 \\
976.429\end{array}$ & $\begin{array}{l}1.866 .058 \\
3.772 .135\end{array}$ & $\begin{array}{l}9.146 .286 \\
1.140 .331\end{array}$ & $\begin{array}{l}910.565 \\
1.660 .715\end{array}$ & $\begin{array}{l}3.283 \\
3.992\end{array}$ & $\begin{array}{l}259.1084 \\
2594\end{array}$ & $\begin{array}{l}1.047 .580 \\
1.510\end{array}$ & $\begin{array}{l}1.447 .847 \\
3.683 .317 \\
\end{array}$ & $\begin{array}{r}931.1417 \\
1.267 .776\end{array}$ & $\begin{array}{l}1.499 .244 \\
1.432 .23\end{array}$ & 5.983 \\
\hline & Transp & 60.766 & 394,488 & 713.687 & 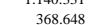 & 548.711 & . & 82906 & 520.255 & 4.001455 & $\begin{array}{l}.1222 .50 \\
42550\end{array}$ & $\begin{array}{l}5360797 \\
56,07\end{array}$ & \\
\hline 25 & Comunicaça & 313 & & & & & & & 36.997 & 90.829 & & 20.170 & \\
\hline 26 & Instituicó̄e ff & & & & & & 466 & & 341.141 & 422.468 & 55.332 & 52.459 & \\
\hline 27 & os às familias & 373.336 & 2.165 & 1.84 & 1.115 .451 & 1.967 .921 & 9.846 & 554.215 & 2.012 .265 & 1.923.123 & 1.238 .734 & 1.886 .537 & 10.326 \\
\hline 28 & às empresas & 17.539 & 22 & & & & 57 & & & & & 408.660 & 3.071 \\
\hline & $\begin{array}{l}\text { Aluguel de imóveis } \\
\text {. }\end{array}$ & & $\begin{array}{r}31.535 \\
250.435\end{array}$ & 912 & & $\begin{array}{r}71.525 \\
0.207\end{array}$ & 248 & $\begin{array}{r}3.247 \\
10177\end{array}$ & & 103.258 & $\begin{array}{l}36.345 \\
46.377\end{array}$ & .799 & \\
\hline $\begin{array}{l}30 \\
31\end{array}$ & 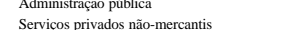 & $\begin{array}{l}86.774 \\
98.062\end{array}$ & $\begin{array}{r}2.594 .435 \\
855.279\end{array}$ & $\begin{array}{l}2.033 .340 \\
1.013 .645 \\
\end{array}$ & $\begin{array}{l}382.454 \\
747.354\end{array}$ & $\begin{array}{l}6140.207 \\
1.400 .499\end{array}$ & $\begin{array}{l}2.890 \\
1.261\end{array}$ & $\begin{array}{l}101.1733 \\
2647.74\end{array}$ & $\begin{array}{l}2.872 .862 \\
1.115837\end{array}$ & $\begin{array}{l}2.167 .624 \\
854478\end{array}$ & $\begin{array}{l}463.177 \\
888095\end{array}$ & $\begin{array}{r}665.2210 \\
152984\end{array}$ & $\begin{array}{c}9.755 \\
3.34\end{array}$ \\
\hline & dos na & 每.0.062 & 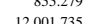 & 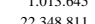 & 年 & $\begin{array}{l}1.400 .4999 \\
11372575\end{array}$ & 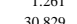 & 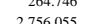 & $\begin{array}{l}1.15158 .871 \\
1.74287\end{array}$ & 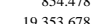 & 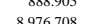 & $\begin{array}{c}1.593 .844 \\
1.39898\end{array}$ & (3.311 \\
\hline
\end{tabular}


ANEXO Y- Número de pessoas ocupadas por jornada semanal de trabalho - 1993/1995.

\begin{tabular}{|c|c|c|c|c|c|c|c|c|c|c|c|c|c|}
\hline & \multirow{2}{*}{ Setor } & & \multirow{2}{*}{\multicolumn{6}{|c|}{1995}} \\
\hline & & até 14 horas & 15 a 39 hora & 40 a 44 horas & 45 a 48 hor: & oras ou mais & $1 . /$ não aplic. & & & & & & \\
\hline 1 & Agropecuária & 307.685 & 4.372 .912 & 3.920 .949 & 1.655 .780 & 5.314 .274 & & 1.904 .497 & 6.173 .364 & 2.081 .005 & 760.780 & $\frac{4.243 .352}{2}$ & \\
\hline 2 & Exrrativa mineral (exceto combus & 542 & 21.901 & 117.460 & 31.242 & 97.055 & & 261 & 1.381 & 127.414 & 7.679 & 93.565 & \\
\hline & Ext.de petróleo e gás natural, carvão e outros & & 2.124 & 16.322 & 5.992 & 5.162 & & & 3.708 & 11.585 & 7.632 & 7.775 & \\
\hline${ }_{5}^{4}$ & Fabricaçăo de minerais não-metálicos & 6.663 & 35.281 & 2139911 & 139.359 & 73.686 & - & 162 & 29.075 & 200.858 & 85.023 & 128.781 & \\
\hline & 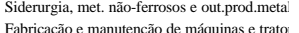 & 3.138 & 50.414 & $\begin{array}{l}388.795 \\
253244\end{array}$ & 228.017 & 87.935 & - & 43.363 & 81.638 & 352.470 & 109.955 & 176.774 & 528 \\
\hline & 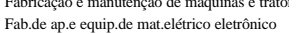 & $\begin{array}{l}1.188 \\
1.018\end{array}$ & $\begin{array}{l}2.0447 \\
10.461\end{array}$ & $\begin{array}{l}253.244 \\
156280\end{array}$ & $\begin{array}{l}88.600 \\
60.049\end{array}$ & $\begin{array}{l}5.0 .640 \\
17.392\end{array}$ & - & $\begin{array}{l}2.632 \\
335\end{array}$ & 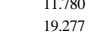 & $\begin{array}{l}353.241 \\
150.107\end{array}$ & $\begin{array}{l}42.72 \\
60.196\end{array}$ & $\begin{array}{l}4.047 \\
46.285\end{array}$ & \\
\hline 8 & Fab.autom.cam.onib.out.veic., pecas e acessí & 1.909 & 6.855 & 168.447 & 110.381 & 35.407 & - & 13.068 & 3.357 & 201.672 & 69.287 & & 25 \\
\hline & Serrarias e fab. de artigos de madeira e mobilit & 8.896 & 77.004 & 322.923 & 205.607 & 204.069 & - & 21.344 & & 358.937 & 139.107 & 262.238 & \\
\hline & Indústria de papel e gráfica & 4.588 & 58.469 & 203.589 & 86.860 & 55.194 & & 2.878 & & 228.877 & & 73.478 & \\
\hline & $\begin{array}{l}\text { Indústria da borracha } \\
\text { Fab Flem gúmicos no-pertroge quím diver }\end{array}$ & 268 & $\begin{array}{c}3.842 \\
10.14\end{array}$ & 37.442 & 23.879 & 6.837 & 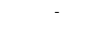 & & 5.002 & $\begin{array}{l}33.007 \\
14000\end{array}$ & 20.008 & 8.883 & \\
\hline & 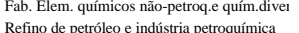 & 268 & 10.314 & $\begin{array}{l}142.130 \\
47772\end{array}$ & 56.395 & 37.893 & - & 183 & 13.380 & 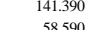 & 41.154 & 40.227 & 66 \\
\hline & 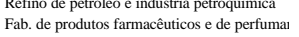 & 1.184 & $\begin{array}{l}3.234 \\
8.113\end{array}$ & 77.200 & $\begin{array}{l}16.432 \\
26.371\end{array}$ & $\begin{array}{c}9.491 \\
13.233\end{array}$ & $\because$ & 7.623 & 1502.461 & $\begin{array}{l}58.909 \\
68.209\end{array}$ & $\begin{array}{r}3.6964 \\
12.139\end{array}$ & $\begin{array}{r}\begin{array}{r}4.414 \\
25.068\end{array}\end{array}$ & \\
\hline & Indústria de transformaçăo de material plástic & & 5.493 & 94.702 & & 18.200 & & 77 & 862 & 124.097 & 29.118 & 10.711 & 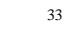 \\
\hline 16 & Indístria t: & 5.846 & 38.118 & 183.770 & & & & 11.873 & & & & & \\
\hline & Fabricaçäa & 103.121 & 498.220 & & 224.014 & 260.737 & 1.591 & 1464.460 & 674.916 & 208 & & & \\
\hline & $\begin{array}{l}\text { Fab. de calcados e de artigos de couro e pele: } \\
\text { Indistri de lamimentos sem geral }\end{array}$ & $\begin{array}{c}4.177 \\
4631\end{array}$ & $\begin{array}{r}30.495 \\
181509\end{array}$ & 278.565 & 62.632 & $\begin{array}{r}52.230 \\
320567\end{array}$ & 1897 & $\begin{array}{r}31.560 \\
172568\end{array}$ & 13.789 & 255.602 & & 30.312 & 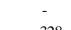 \\
\hline & $\begin{array}{l}\text { Indístrtaia de alimentos em geral } \\
\text { Indústras diversans }\end{array}$ & 46.31 & $\begin{array}{l}181.509 \\
53362\end{array}$ & 545.958 & 377.848 & $\begin{array}{l}328.567 \\
50374\end{array}$ & 1.887 & 172.568 & 282.168 & 398.417 & 271.647 & $\begin{array}{l}410.672 \\
17258\end{array}$ & 328 \\
\hline 21 & $\begin{array}{l}\text { Industrnas diversas } \\
\text { Servicos industriais de utilidadade pública }\end{array}$ & $\begin{array}{c}18.380 \\
219\end{array}$ & $\begin{array}{l}53.632 \\
37.928\end{array}$ & $\begin{array}{l}11.8411 \\
207.705\end{array}$ & $\begin{array}{l}50.278 \\
42.245\end{array}$ & $\begin{array}{l}50.374 \\
27.004\end{array}$ & & 37.29 & $\begin{array}{l}1.7 .916 \\
15.901\end{array}$ & $\begin{array}{l}160.180 \\
168.079\end{array}$ & & $\begin{array}{l}1.2 .38 \\
45.345\end{array}$ & \\
\hline & Constru & 33.377 & 239.331 & 1.423 .941 & 990 & & 1.080 & & 246.962 & 1.387 .717 & 673.156 & 1.070 .797 & 280 \\
\hline & Comé & 172.104 & 1.154.774 & 3.485.984 & 1.443 .557 & & & 65.587 & 1.199 .342 & 4.352.205 & - & 1.835 .435 & \\
\hline & Transporte & 135.983 & 427.824 & 527.346 & 380.032 & 581.262 & 12.454 & 11.161 & & 1 & 684.380 & 642.823 & \\
\hline & Comunicaçōes & 1.067 & $\begin{array}{r}23.458 \\
325585\end{array}$ & 121.989 & & & - & 233 & 20.715 & 116.818 & 33.450 & 11.383 & \\
\hline & sfamilias & $\begin{array}{r}4.640 \\
461.443\end{array}$ & $\begin{array}{r}3.255 .1 .18 \\
2.007\end{array}$ & 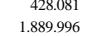 & $\begin{array}{r}62.403 \\
1.167 .234\end{array}$ & $\begin{array}{r}6.3819 \\
2.001 .216\end{array}$ & 11.441 & 741.283 & $\begin{array}{r}2044653 \\
2.486 .273\end{array}$ & $\begin{aligned} 4.900 .792 \\
1.699332\end{aligned}$ & 6 & $\begin{array}{r}94.176 \\
2.309 .118\end{array}$ & 30.475 \\
\hline 28 & empresas & 32. & & & & & & & & 671.312 & 373.551 & 412.583 & \\
\hline 29 & Aluguel de & 1.985 & & 105.077 & & & & & & & & & \\
\hline & Administraçăo pública & 93.398 & 2.352 .294 & 2.390 .353 & 428.717 & 695.948 & 4.790 & 187.833 & 1.888 .406 & 2.093.508 & 354.835 & 794.163 & 254 \\
\hline & Servicos privados não-mercantis & 218.139 & $\begin{array}{l}1.052 .331 \\
.1 .6302\end{array}$ & $\begin{array}{l}1.102 .786 \\
200959\end{array}$ & 947.403 & 1.517 .565 & 577 & 310.693 & 1.632 .936 & $\begin{array}{l}1.007 .547 \\
8025515\end{array}$ & 786.583 & $\begin{array}{l}1.668 .790 \\
5871193\end{array}$ & 150 \\
\hline & & & & & & & & & & & & & \\
\hline
\end{tabular}


ANEXO Y - Número de pessoas ocupadas por jornada semanal de trabalho - 1996 -1997.

\begin{tabular}{|c|c|c|c|c|c|c|c|c|c|c|c|c|c|}
\hline & Setor & \multicolumn{6}{|c|}{$\begin{array}{c}1996 \\
40 \mathrm{a} 44 \text { horas } 45 \text { a } 48 \text { horas } 9 \text { horas ou mais lecl. / não aplic. }\end{array}$} & \multicolumn{6}{|c|}{1997} \\
\hline 1 & Agropecuária & $\begin{array}{ll}\text { ate } 14 \text { horas } \\
831.356\end{array}$ & $\frac{15 \text { a } 39 \text { horas }}{3.852 .971}$ & $\frac{40 \mathrm{a} 44 \text { horas }}{2.256 .021}$ & $\frac{45.48 \text { horas } 9}{1.402 .770}$ & $\begin{array}{ll}\text { loras ou mais } \\
5.457 .608\end{array}$ & $\begin{array}{ll}\mid / \text { ñá aplic. } \\
105.074\end{array}$ & até 14 haras & $\begin{array}{ll}15 \mathrm{a} 3 \mathrm{~h} \text { horas } \\
4.277 .275\end{array}$ & $\begin{array}{ll}40 \mathrm{a} 44 \text { hroras } \\
2.403 .606\end{array}$ & 15 a 4 48 horos & $\begin{array}{ll}\text { horas ou mais lecl } \\
4.648 .708\end{array}$ & / Ināo aplic. \\
\hline 2 & Extrativa mineral (exceto combustiveis) & & & & & & & 1.020 & & 82.597 & & & \\
\hline 3 & Ext.de petróleo e gás natural, carvão e outros & 454 & 1.875 & 12.715 & 5.580 & 5.676 & - & & 2.158 & 9.669 & 8.032 & 5.041 & \\
\hline 4 & Fabricação de minerais não-metálicos & 3.130 & 26.579 & 186.302 & 124.393 & 95.596 & & 1.087 & 40.555 & 197.697 & 114.135 & 98.978 & 149 \\
\hline & d.metal & & & & & & & & & & & & \\
\hline & icacaca & 5.341 & 21.370 & 215.714 & 107.646 & 67.032 & 3977 & 2.81 & & 236.730 & & 56.243 & \\
\hline 7 & Fab.de ap.e equip.de mat.lértic & 1.053 & 12.241 & 138.289 & 62.176 & 40.341 & & 1.940 & 14.338 & 146.165 & 54.517 & 27.941 & \\
\hline & Fab.autom.cam.onib.out.veic., pecas e & 1.273 & 7.742 & 169.207 & 81.654 & 32.025 & & 1.433 & 7.078 & 166.010 & 85.149 & 28.631 & \\
\hline & Serrarias e fab. de artigos de madeira e mobilit & 11.729 & 81.648 & 325.273 & 234.305 & 202.843 & 303 & 6.808 & 70.879 & 351.925 & 205.313 & 199.875 & \\
\hline & Indústria de papel e gráfica & 5.372 & 50.731 & 215.043 & 86.287 & 65.580 & 186 & 6.055 & 37.724 & 233.821 & 73.755 & 59.445 & \\
\hline & Indústria da borracha & 2.541 & 32.500 & 14.458 & 5.401 & & & & 3.568 & 31.980 & 417 & 6.135 & \\
\hline & Fab. Ele & 21 & 10.749 & 104.573 & 63.972 & 50.085 & & 856 & 9.172 & 127.824 & 59.743 & 42.105 & \\
\hline & Refino de petróleo e indústria petroquímica & 4.866 & & & & & 5 & & 2.280 & 35.381 & 13.562 & $\begin{array}{r}8.676 \\
16509\end{array}$ & \\
\hline $\begin{array}{l}14 \\
15\end{array}$ & 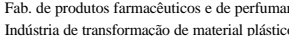 & $\begin{array}{l}3.047 \\
778\end{array}$ & $\begin{array}{l}10.741 \\
9.152\end{array}$ & $\begin{array}{r}71.228 \\
100.424\end{array}$ & 26.078 & $\begin{array}{l}14.606 \\
32.900\end{array}$ & : & $\begin{array}{l}2.247 \\
2.135\end{array}$ & 9.438 & $\begin{array}{c}72.267 \\
174.37\end{array}$ & 25.638 & $\begin{array}{l}16.509 \\
19785\end{array}$ & 227 \\
\hline 16 & Indusústra a têtrian & 5.119 & $\begin{array}{l}1.152 \\
29.894\end{array}$ & $\begin{array}{l}120.42 .64 \\
1274\end{array}$ & $\begin{array}{l}5.737 \\
52.767\end{array}$ & $\begin{array}{l}32.290 \\
3.265\end{array}$ & - & $\begin{array}{l}2.135 \\
7.608\end{array}$ & $\begin{array}{l}10.118 \\
29.343\end{array}$ & $\begin{array}{l}134.3720 \\
134726\end{array}$ & $\begin{array}{l}46.355 \\
39.081\end{array}$ & $\begin{array}{l}19.785 \\
26.043\end{array}$ & 227 \\
\hline & Fabricaąão de artigos do vestuário e acessórit & 94.119 & 482.178 & 489.257 & 238.177 & 284.137 & 633 & 94.731 & 474.617 & 488.284 & 189.258 & 203.236 & \\
\hline & Fab. de & & 14.610 & 222.540 & 60.364 & 44.221 & 249 & 1.814 & & 0 & & 24.830 & \\
\hline & Indit & 54.034 & 174.170 & 498.435 & 335.5 & 423.719 & & 54.379 & & 491.8 & 332.417 & 399.049 & \\
\hline & Indúst & & & & & & - & & & & & & \\
\hline & triais de utilidade pública & 725 & 21.234 & 145.960 & & 22.443 & & 1.207 & & 154.602 & 372 & 19.893 & \\
\hline & Constu & & 241.636 & 1.469 .085 & 892.875 & 871.429 & 1.286 & 40.235 & 214.978 & 1.512 .825 & 1.004 .657 & 927.226 & 878 \\
\hline & Comér & 128.351 & 1.264 .388 & 3.972 .823 & 1.194.532 & 2.165 .347 & 18.859 & 202.221 & 1.133 .412 & 3.669.727 & 1.440 .973 & 2.431 .645 & 1923 \\
\hline & Trans: & 115.748 & 442.501 & & 387.6 & 606.779 & 6.768 & 195.888 & 554.851 & 589.739 & 433.981 & 593.841 & \\
\hline & & & & 109.525 & & & & & & (2) & & 16.433 & \\
\hline & Instituiç̄óes & 6.604 & 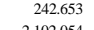 & 367.368 & 58.839 & 74.037 & & & & 391.739 & & ${ }^{76.615}$ & 348 \\
\hline & 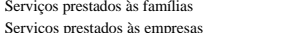 & 524.819 & $\begin{array}{l}2.1020 .054 \\
408169\end{array}$ & $\begin{array}{l}2.242 .950 \\
7733138\end{array}$ & $\begin{array}{l}1.406 .131 \\
408562\end{array}$ & $\begin{array}{r}2.504 .733 \\
526328\end{array}$ & 15.012 $\begin{array}{c}105 \\
505\end{array}$ & 527.922 & $\begin{array}{l}2.251 .148 \\
413399\end{array}$ & $\begin{array}{l}2.303 .846 \\
883618\end{array}$ & $\begin{array}{l}1.391 .761 \\
.46580\end{array}$ & $\begin{array}{l}2.502 .626 \\
.48967\end{array}$ & 7 \\
\hline & $\begin{array}{l}\text { Servygus pre } \\
\text { Aluguel de in }\end{array}$ & $\begin{array}{l}4.201 \\
3.559\end{array}$ & $\begin{array}{l}480.169 \\
40.819\end{array}$ & $\begin{array}{l}728.1 .38 \\
127.321\end{array}$ & $\begin{array}{l}480.622 \\
51.281\end{array}$ & $\begin{aligned} & 526.328 \\
56.220 & \end{aligned}$ & 503 & $\begin{array}{l}3.3 .134 \\
2.375\end{array}$ & & $\begin{array}{l}838.618 \\
131.331\end{array}$ & 446.580 & $\begin{array}{l}428.077 \\
52774\end{array}$ & \\
\hline & $\begin{array}{l}\text { Auguel deimmovels } \\
\text { Administraçá publica }\end{array}$ & $\begin{array}{r}3.539 \\
102.993\end{array}$ & $\begin{array}{r}2.084 .459 \\
-299\end{array}$ & $\begin{array}{r}1.077 .3737 \\
2.375\end{array}$ & $\begin{array}{r}51.281 \\
455.539\end{array}$ & $\begin{array}{r}30.2 \mathrm{v} \\
628.900\end{array}$ & 1.435 & 99.981 & $\begin{array}{r}409.132 \\
1.990 .814\end{array}$ & & & & \\
\hline & vados não-mercantis & 344.472 & 1.274 .359 & 1.264 .398 & 987.266 & 1.4. & 6 & 370.260 & 387 & 1.193.822 & & & \\
\hline & & 6.262 & 077.249 & 19.047.075 & 9.129.771 & 15.989 .368 & 154.876 & 2.655.426 & 13.514.887 & 19.170.168 & 9.391.218 & 5.369.394 & 21.807 \\
\hline
\end{tabular}


ANEXO Y - Número de pessoas ocupadas por jornada semanal de trabalho - 1998 -1999.

\begin{tabular}{|c|c|c|c|c|c|c|c|c|c|c|c|c|c|}
\hline & Setor & \multicolumn{6}{|c|}{1998} & \multicolumn{6}{|c|}{1999} \\
\hline 1 & $\begin{array}{l}\text { Agropecúríi }\end{array}$ & 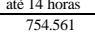 & $\frac{3.390 \text { hras }}{3.508 .290}$ & $\frac{0.44 \text { thras }}{2.958 .221}$ & $\frac{5 \text { a } 4.5 \text { horas } 9}{1.558 .86}$ & 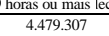 & naio palic. & $\frac{14 \text { horosas }}{802.006}$ & $\frac{5 \text { a } 39 \text { horas }}{4.295 .937}$ & 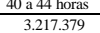 & $\frac{5 \mathrm{a} 4 \mathrm{4h} \text { horas }}{1.746 .138}$ & $\begin{array}{ll}\text { ras ou mals } \\
4.276 .834\end{array}$ & ata aplic. \\
\hline & Extrativa mineral (exceto combustíveis) & 4.322 & 21.860 & & 46.363 & 64.447 & & 1.916 & 22.124 & & & & \\
\hline 3 & Ext.de petróleo e gás natural, carvão e outros & & 4.127 & 14.593 & 2.874 & 5.606 & & & 3.808 & 21.249 & 5.548 & 6.396 & \\
\hline 4 & Fabricaçăo de minerais não-metálicic & 3.598 & 36.766 & 163.349 & 123.006 & 86.504 & 477 & 3.906 & 32.362 & 202.843 & 120.510 & 70.779 & \\
\hline 5 & Siderurgia, met. não-ferrosos e o & 7.969 & 47.697 & 407.072 & 196.945 & 130.634 & 1.184 & 4.504 & & 386.487 & 173.605 & 111.028 & \\
\hline & Fabricacăi & 1.810 & 19.309 & 233.626 & 81.638 & 51.817 & & 1.966 & 20.704 & 211.935 & 90.774 & 55.520 & \\
\hline 7 & Fab.de ap.e equip. & 739 & 11.273 & $\begin{array}{l}151.117 \\
15.67\end{array}$ & $\begin{array}{ll}42.612 \\
6.554\end{array}$ & $\begin{array}{l}24.958 \\
3.979\end{array}$ & - & 865 & 8.844 & 0.891 & 08 & 26.693 & - \\
\hline & 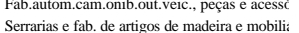 & $\begin{array}{r}895 \\
12.134\end{array}$ & $\begin{array}{r}7.725 \\
71.188\end{array}$ & 135.627 & $\begin{array}{r}63.554 \\
138518\end{array}$ & $\begin{array}{l}32.799 \\
205983\end{array}$ & 492 & $\begin{array}{r}867 \\
10.301\end{array}$ & $\begin{array}{l}10.989 \\
71207\end{array}$ & 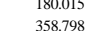 & $\begin{array}{c}62.620 \\
112857\end{array}$ & $\begin{array}{l}25.3099 \\
189238\end{array}$ & \\
\hline 10 & $\begin{array}{l}\text { Indústria de papel e gráfica } \\
\text { Intion }\end{array}$ & 4.025 & 45.525 & 214.200 & 75.176 & 69.335 & 2.139 & 1.731 & 43.278 & 235.808 & 73.240 & $\begin{array}{l}63.243 \\
61.243\end{array}$ & \\
\hline 11 & Indústria da borracha & 632 & 596 & 26.678 & & 7.865 & & 446 & 1.727 & 25.320 & 14.245 & 4.863 & \\
\hline & Fab. Ele & $837 \mathrm{C}$ & 8.386 & & & & - & & & 117.955 & & & \\
\hline & Refino de petróleo & 419 & 461 & & & 10.892 & - & 975 & & & & 6.872 & - \\
\hline & $\begin{array}{l}\text { Fab. de produtos } \\
\text { Ind́striade tenst }\end{array}$ & 718 & 5.266 & $\begin{array}{l}71.181 \\
98543\end{array}$ & $\begin{array}{l}30.867 \\
46698\end{array}$ & 20.368 & $-\mathrm{s}$ & 656 & 13.360 & 64.240 & 27.028 & 14.117 & \\
\hline $\begin{array}{l}15 \\
16\end{array}$ & $\begin{array}{l}\text { lndustrira de transformaçáo de material plastici } \\
\text { Indústria texxil }\end{array}$ & 5.321 & $\begin{array}{r}5.213 \\
32.030\end{array}$ & $\begin{array}{c}98.53 \\
118.358\end{array}$ & $\begin{array}{l}466978 \\
46.148\end{array}$ & $\begin{array}{l}33.786 \\
29.143\end{array}$ & - & 5.712 & 32.017 & 1122.8056 & $\begin{array}{l}53.247 \\
54002\end{array}$ & $\begin{array}{l}21.271 \\
29262\end{array}$ & - \\
\hline & Fabricaçăo de artigos do vestuário e acessórii & $\begin{aligned} 10.321 \\
106.241\end{aligned}$ & $\begin{aligned} 220.300 \\
42030\end{aligned}$ & 450.816 & 189.847 & 241.1464 & 973 & 96.599 & 438.825 & 497.762 & $\begin{array}{r}34.002 \\
195.940\end{array}$ & 222.1141 & 32 \\
\hline 18 & Fab. dec $c$ & 1.335 & 16.318 & 219.075 & 56.196 & 576 & & 5.451 & & 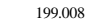 & 60248 & 47.581 & \\
\hline & os em ger & 50.824 & 191.496 & 490.830 & 337.696 & 395.631 & 1.824 & 694 & 226.914 & 7.305 & 346.015 & 350.441 & 2.031 \\
\hline & $\begin{array}{l}\text { Indústria } \\
\text { Services }\end{array}$ & 13.471 & & & & & & 14.224 & & & & 38.011 & \\
\hline & $\begin{array}{l}\text { Servicosininustriaisis de utilidade pública } \\
\text { Construço civil }\end{array}$ & $\begin{array}{r}785 \\
72.584\end{array}$ & $\begin{array}{l}{ }^{28.997} \\
414.491\end{array}$ & $\begin{array}{r}152.867 \\
1.550 .10\end{array}$ & $\begin{array}{r}31.345 \\
0994.401\end{array}$ & $\begin{array}{l}24.007 \\
249938\end{array}$ & & 6259 & 24.887 & $\begin{array}{l}133.750 \\
521309\end{array}$ & $\begin{array}{r}33.460 \\
1025259\end{array}$ & & 2433 \\
\hline & $\begin{array}{l}\text { Construçaco civil } \\
\text { Comércio }\end{array}$ & 72.584 & $\begin{array}{r}1.34 .491 \\
1.774 .814\end{array}$ & 1.530 .010 & 9988.401 & 998.338 & 2.177 & $\begin{array}{l}63.902 \\
206.150\end{array}$ & 359.740 & .1.521.309 & 1.025.259 & $\begin{array}{l}936,154 \\
247917\end{array}$ & 2.436 \\
\hline & Transp & 133.921 & 618.532 & 595.2 & 465.423 & $\begin{array}{r}2.009 .922 \\
597.665\end{array}$ & $\begin{array}{l}3.450 \\
3.141\end{array}$ & 142.188 & 619.168 & 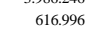 & 383.496 & 621.852 & 6.79 \\
\hline & & 1.1. & & 125.810 & & & 134 & & & 116.588 & & & \\
\hline & & 4.065 & 188.404 & 342.751 & 74.623 & & 668 & 11.038 & & & & & \\
\hline & Servi & 562.416 & 2.341.099 & 2.371.355 & 1.418.031 & 2.579 .616 & 15.384 & 578.693 & 2.392 & 2.532.344 & 1.446 & 2.502 .744 & \\
\hline 28 & Ser & 38.488 & 436.9 & & 455.2. & 589. & 2.387 & & & & & 548.247 & 776 \\
\hline & & 4.5 & & & & & & & & & & & \\
\hline 30 & & & 2.12 & 2.18 & & 647.546 & 1.516 & 87.602 & 2.177 .695 & 2.286.412 & & 646.956 & 1.537 \\
\hline 31 & $\begin{array}{l}\text { Servicos privados näo-mercantis } \\
\text { TOTA }\end{array}$ & $\begin{array}{r}349.251 \\
0.380269\end{array}$ & $\begin{array}{l}1.400 .932 \\
1.30184\end{array}$ & $\begin{array}{l}1.259 .481 \\
10177132\end{array}$ & $\begin{array}{r}980.902 \\
0.6753\end{array}$ & $\begin{array}{l}1.429 .477 \\
1590025\end{array}$ & $\begin{array}{r}4.857 \\
8026\end{array}$ & $\begin{array}{l}377.076 \\
.255953\end{array}$ & $\begin{array}{l}1.437 .555 \\
.1440631\end{array}$ & $\begin{array}{l}1.340 .295 \\
2085501\end{array}$ & $\begin{array}{l}1.009 .160 \\
0.632303\end{array}$ & $\begin{array}{l}1.425 .410 \\
1.909494\end{array}$ & \\
\hline & & & & & & & & & & & & & \\
\hline
\end{tabular}


ANEXO W - Variação da produtividade aparente dos macro setores em relação a $1990(1990=100)$

\begin{tabular}{|c|c|c|c|c|c|c|c|c|c|c|}
\hline Setores & 1990 & 1991 & 1992 & 1993 & 1994 & 1995 & 1996 & 1997 & 1998 & 1999 \\
\hline Agropecuária & 100 & $\overline{99,00}$ & 102,38 & 100,38 & 106,87 & 105,47 & 112,44 & 100,81 & 104,32 & $\overline{99,42}$ \\
\hline Extrativa mineral (exceto combustíveis) & 100 & 110,81 & 100,81 & 99,00 & 113,85 & 112,64 & 112,63 & 104,05 & 90,13 & 103,75 \\
\hline Ext.de petróleo e gás natural, carvão e outros comb. & 100 & 97,72 & 101,71 & 112,11 & 105,62 & 100,42 & 129,57 & 112,56 & 92,94 & 89,25 \\
\hline Fabricação de minerais não-metálicos & 100 & 108,98 & 98,18 & 107,49 & 105,98 & 107,61 & 103,64 & 102,28 & 103,02 & 95,51 \\
\hline Siderurgia, met ñ-ferrosos e out.prod.metalurgicos & 100 & 107,46 & 105,83 & 113,07 & 110,87 & 97,92 & 100,70 & 103,42 & 89,49 & 101,69 \\
\hline Fabricação e manutenção de máquinas e tratores & 100 & 106,17 & 100,67 & 118,70 & 109,10 & 100,09 & 101,53 & 105,98 & 97,72 & 107,04 \\
\hline Fab.de ap.e equip.de mat.elétrico eletrônico & 100 & 113,12 & 104,32 & 120,05 & 114,87 & 108,74 & 112,88 & 101,01 & 101,46 & 95,49 \\
\hline Fab.auto.cam.onib.out.veic., peças e acessórios & 100 & 117,25 & 108,84 & 118,36 & 110,12 & 105,02 & 111,77 & 111,40 & 93,15 & 93,39 \\
\hline Serrarias e fab. de artigos de madeira e mobiliário & 100 & 99,43 & 101,48 & 104,02 & 99,29 & 99,88 & 102,17 & 103,60 & 98,77 & 111,25 \\
\hline Indúst & 100 & 108,27 & 100,21 & 117,88 & 99,19 & 99,81 & 104,39 & 104,47 & 97,33 & 105,74 \\
\hline Indústria da b & 100 & 106,17 & 103,59 & 113,29 & 105,14 & 103,59 & 122,83 & 106,04 & 96,44 & 84,93 \\
\hline Fab. Elem & 100 & 108,00 & 100,35 & 112,77 & 107,82 & 101,62 & 108,28 & 100,96 & 96,78 & 105,98 \\
\hline Refi & 100 & 112,62 & 107,41 & 105,50 & 108,27 & 107,53 & 105,04 & 110,57 & 126,83 & 105,57 \\
\hline Fab. c & 100 & 103,22 & 93,54 & 103,21 & 101,50 & 107,32 & 100,19 & 106,14 & 102,57 & 114,08 \\
\hline Indú & 100 & 104,34 & 97,12 & 106,03 & 106,18 & 108,14 & 100,56 & 99,54 & 91,12 & 69,09 \\
\hline Indúst & 100 & 101,37 & 101,01 & 104,66 & 105,18 & 105,44 & 117,80 & 97,26 & 97,24 & 96,62 \\
\hline Fabric & 100 & 90,98 & 97,56 & 98,94 & 100,75 & 99,36 & 101,79 & 101,19 & 105,34 & 107,55 \\
\hline $\mathrm{Fal}$ & 100 & 98,16 & 104,66 & 109,40 & 97,54 & 104,92 & 107,16 & 99,24 & 90,72 & 117,22 \\
\hline Indústr & 100 & 100,14 & 97,93 & 105,63 & 101,74 & 105,92 & 105,03 & 101,09 & 99,42 & 103,70 \\
\hline Indústrias diversas & 100 & 99,49 & 93,66 & 101,86 & 109,35 & 105,23 & 116,97 & 98,52 & 86,15 & 104,56 \\
\hline Serv & 100 & 113,03 & 105,43 & 96,82 & 115,80 & 119,61 & 116,50 & 105,08 & 117,26 & 116,15 \\
\hline Con & 100 & 105,63 & 99,96 & 101,58 & 109,02 & 101,16 & 102,41 & 102,45 & 92,91 & 99,67 \\
\hline Com & 100 & 98,63 & 95,54 & 101,43 & 105,42 & 104,61 & 103,27 & 101,40 & 91,57 & 92,41 \\
\hline & 100 & 102,75 & 103,73 & 103,05 & 99,40 & 101,77 & 102,81 & 99,17 & 91,62 & 91,22 \\
\hline Comu & 100 & 123,23 & 102,53 & 107,12 & 109,92 & 124,26 & 116,33 & 110,08 & 119,56 & 147,25 \\
\hline Instit & 100 & 103,48 & 101,26 & 96,72 & 102,27 & 96,63 & 109,24 & 102,97 & 107,79 & 99,55 \\
\hline Serv & 100 & 99,58 & 101,84 & 104,42 & 97,73 & 94,86 & 100,63 & 98,71 & 90,33 & 95,99 \\
\hline Serviç & 100 & 99,66 & 99,68 & 104,78 & 97,80 & 97,53 & 98,08 & 100,92 & 97,01 & 104,42 \\
\hline Alugu & 100 & 117,93 & 114,78 & 107,09 & 94,05 & 91,12 & 105,48 & 106,22 & 107,45 & 94,75 \\
\hline Adm & 100 & 96,95 & 97,25 & 107,59 & 106,36 & 106,75 & 100,48 & 102,37 & 99,74 & 100,60 \\
\hline Serviços privados não-mercantis & 100 & 91,09 & 99,87 & 99,57 & 98,92 & 98,74 & 97,35 & 100,13 & 99,45 & 99,85 \\
\hline
\end{tabular}


ANEXO Z - Participação dos componentes na demanda total 1990 - 1994

\begin{tabular}{|c|c|c|c|c|c|c|c|c|c|c|c|c|c|c|c|}
\hline & Consumo & $\begin{array}{r}1990 \\
\text { Demanda }\end{array}$ & & Consumo & $\begin{array}{r}1991 \\
\text { Demanda }\end{array}$ & & Consumo & $\begin{array}{r}1992 \\
\text { Demanda }\end{array}$ & & Consumo & $\begin{array}{r}1993 \\
\text { Demanda }\end{array}$ & & Consumo & $\begin{array}{r}1994 \\
\text { Demanda }\end{array}$ & \\
\hline $\begin{array}{l}\text { Agropecuária } \\
\end{array}$ & $\begin{array}{r}\text { Intermediário } \\
37.74\end{array}$ & $\frac{\text { Final }}{5954}$ & $\frac{\text { Exportacăo } 1}{272}$ & $\frac{\text { temediário }}{3750}$ & $\frac{\text { Final }}{6040}$ & Exportaçán & $\frac{\text { termediário }}{3496}$ & Final & $\frac{\text { Exportacắ I }}{209}$ & neremediário & $\begin{array}{r}\text { Final } \\
6483\end{array}$ & $\frac{\text { Exportaçác }}{283}$ & ntermediário & Final & 2,95 \\
\hline Extrativa mineral (exceto combustiveis) & $-0,60$ & 59,33 & 41,27 & $-0,72$ & 51,42 & 49,30 & 2,58 & 49,34 & 48,08 & -2.59 & 55,65 & 46,94 & 2,83 & 56,65 & 40,52 \\
\hline Ext.de petróleo e gás natural, carvão e outros $a$ & 5.58 & 94.33 & 0.09 & 5,44 & 94,43 & 0.13 & 0.42 & 99.43 & 0.15 & -1.93 & 101.91 & 0.02 & -3.36 & 103,34 & \\
\hline Fabricação de minerais não-metálicos & 7,98 & 89,75 & 2,27 & 8,88 & 88,21 & 2,91 & 7,6 & 88,78 & 3,55 & 6,23 & 89,43 & 4,35 & 5,61 & 90,74 & \\
\hline Imetalurgic & 3,51 & 84,60 & 11,89 & 3,96 & $81,2$. & 14,77 & 5,6 & 78,99 & 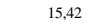 & 5,00 & 80,40 & 14,60 & 5,91 & 80,96 & \\
\hline & 42,80 & & 5,16 & 44,49 & & 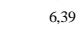 & 37, & & 8,8 & 41. & 50, & & & 43,00 & \\
\hline $\mathrm{Fa}$ & 58,01 & & 4,34 & 58,25 & & 6,1 & 57. & & 7, & & & & 64,22 & 27 & \\
\hline & 53,09 & 9 & 8,92 & 53,64 & & 10,87 & 51, & 88 & 15 , & & 32 & 08 & 8 & 76 & \\
\hline liári & 54,45 & 42,36 & 3,18 & 59,06 & 36,63 & 4,31 & 51,12 & $\begin{array}{l}30,06 \\
40,99\end{array}$ & 7,89 & 87 & 39,45 & 10,68 & $\begin{array}{l}50,83 \\
50,13\end{array}$ & 40,01 & \\
\hline Indústria & 17,95 & 79 & 5,27 & 19,62 & 74,28 & 6,09 & 14,90 & 76,19 & 8,91 & 15,95 & 76,04 & 8,01 & 16,15 & 75,32 & \\
\hline Indústria da borracha & 3,05 & 92,88 & 4,07 & 3,14 & 91,04 & 5,82 & 1,47 & 1,17 & 7,36 & 2,68 & 89,85 & 7,47 & 4,54 & 88,52 & \\
\hline Fab. Elem. químicos não-petroq.e q & 17,25 & 79,83 & 2,92 & 18,49 & 78,38 & 3,13 & 14,39 & 81,68 & 3,92 & 12,81 & 83,24 & 3,95 & 15,68 & 80,80 & \\
\hline Refino de petrofleo e indústria pertroquímica & 7,71 & 87,51 & 4,77 & 6,52 & 89,60 & 3,88 & 9,98 & 85,34 & 4,68 & 9,91 & 85,45 & 4,63 & 9,25 & 86,33 & \\
\hline Fab. de produtos $\mathrm{fa}$ & 75,89 & 23,03 & 1,08 & 71,96 & 25,86 & 2,18 & 74,80 & 30 & 1,90 & 75,51 & 22,43 & 2,06 & 76,69 & 21,44 & \\
\hline Indústria de transformaç̃o de material plástico & 8,31 & 90,45 & 1,24 & 8,07 & 90,09 & 1,84 & 7,13 &, 71 & 3,16 & 8,52 & 88,25 & 3,23 & 9,08 & 88,02 & \\
\hline Indústria têxtil & 22,22 & 72,96 & 4,81 & 21,40 & 72,05 & 6,55 & 21,37 & 70,57 & 8,06 & 22,16 & 71,04 & 6,81 & 23,98 & 70,02 & \\
\hline Fabricaçãa & 95,55 & 3,50 & 0,95 & 95,33 & 3,48 & 1,19 & 93,78 & 4,13 & 2,09 & 95,12 & 2,69 & 2,19 & 95,68 & 2,39 & \\
\hline Fab, de calc & 58,80 & 23,42 & 17,78 & 61,05 & 19,06 & 19,89 & & 18,79 & 35,38 & 49 & 17,61 & 33,90 & 53,74 & 18,96 & \\
\hline ústria de & 60,04 & 30,52 & 9,44 & 61,39 & & 9,00 & & 3034 & 11, & & 31, & ( & 57,86 & 30,92 & \\
\hline Indústrias divs & 40,20 & & 2,35 & 40 & $55,7$. & & 41, & & 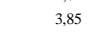 & & 52, & 6. & 45, & 49,50 & \\
\hline & 28,44 & & & 24, & 75,25 & 0, & & & & & 70, & 0, & 30, & 69,46 & \\
\hline & & & & & & & & & & & & 0,0 & & 9,90 & \\
\hline & & & & & & & & & & & & & & & \\
\hline & 36,13 & 51 & 12,04 & & & 11,32 & & & 11 & & & & & & \\
\hline & & & 1,36 & & 69 & 0,6 & & & 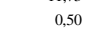 & & 56. & & & & \\
\hline & & & 0,1 & & 86 & 0,1 & & & 0,8 & & 89 & 0,03 & 17 & & \\
\hline & 74,26 & & 2,56 & 75. & 21 & 2,3 & 76 & 1,88 & 1,87 & 75 & 22 & 2,45 & 8 & 21 & \\
\hline resa: & 6,85 & 92,46 & 0,68 & 6,78 & 92,31 & 0,92 & 7. & 91,29 & 1,3 & 7,30 & 90 & 76 & 6 & 47 & \\
\hline Alug & 86,29 & 13,71 & 0,00 & 92,65 & 7,35 & 0,00 & 91, & 8,62 & 0,00 & 87 & 12, & 0,00 & 86,23 & 13,77 & \\
\hline Administraçăo pública & & 9,53 & 0,28 & & & 0,24 & & 6, & 0,31 & & 8,2 & 0,41 & 91,30 & 8,25 & \\
\hline Serviços privados não-mercantis & 100,00 & 0,00 & 0,00 & 100,00 & 0,00 & 0,00 & 100,00 & 0,00 & 0,00 & 100,00 & 0,00 & 0,00 & 100,00 & 0,00 & \\
\hline
\end{tabular}




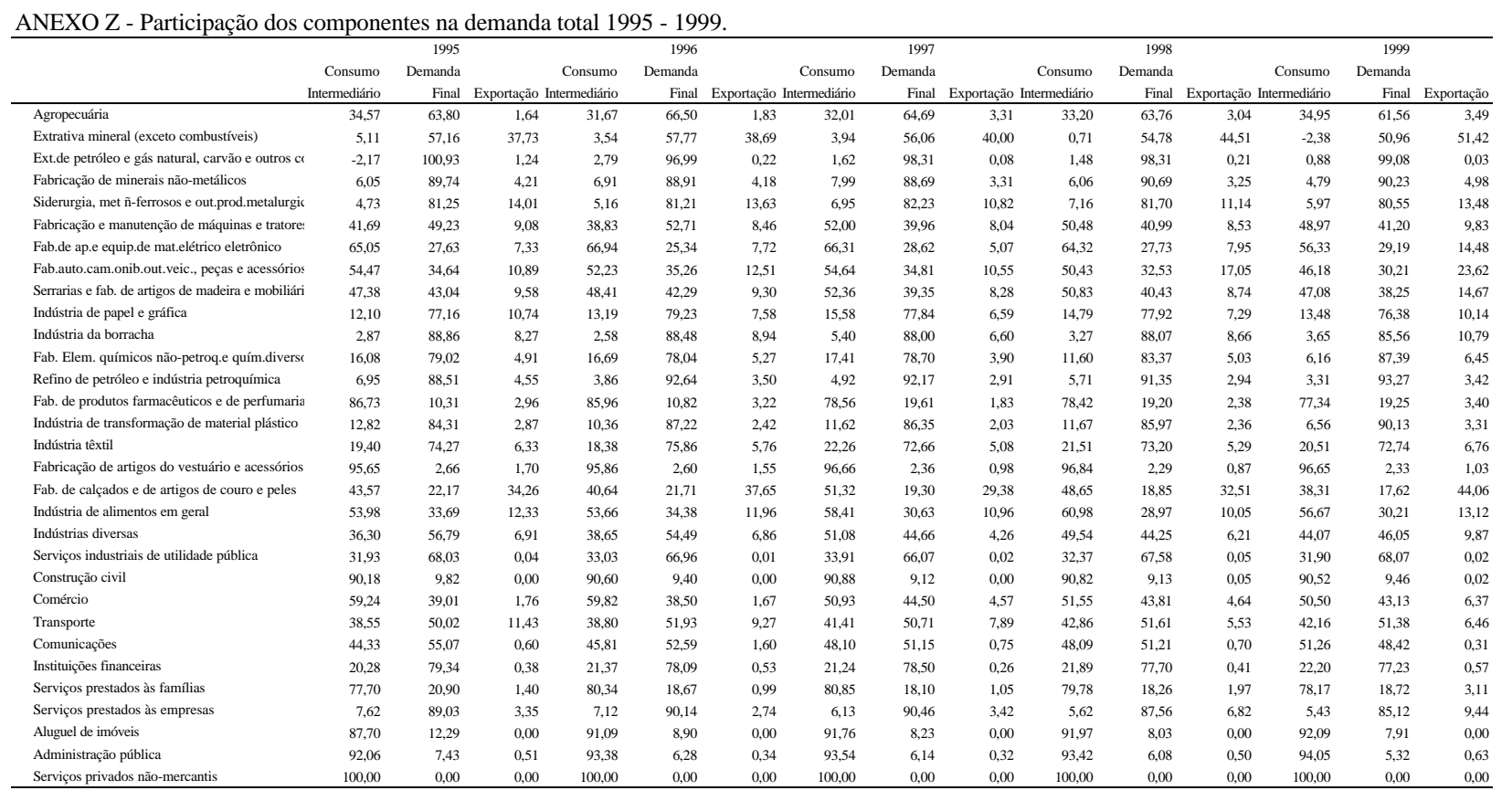




\section{CONCLUSÕES GERAIS}

Durante a década de 1990 a economia brasileira passou por mudanças na estrutura de produção e na oferta de postos de trabalho decorrentes da implementação do plano de estabilização do nível de preços e da consolidação do processo de abertura econômica.

As mudanças no processo produtivo permitiram que setores como a Agropecuária e Serviços aumentassem sua participação relativa no total da produção. Não obstante, a queda no valor dos multiplicadores de produção indicou que, de modo geral, os setores tornaram-se mais dependentes dos insumos importados. Isto parece indicar que a economia brasileira demonstrou ser mais importadora de produtos intensivos em capital e exportadora de produtos intensivos em trabalho.

Os multiplicadores de emprego mostraram que todos os setores apresentaram queda na capacidade de geração de novos postos de trabalho (empregos diretos, indiretos e induzidos). No entanto, os setores Agropecuária e Serviços ainda parecem possuir maior capacidade de geração de postos de trabalho. Isto pode ser parcialmente explicado pela utilização intensiva do trabalho nestes setores.

Os resultados do impacto da abertura da economia sobre o emprego mostraram que a reestruturação produtiva dela decorrente teve um impacto significativo sobre a geração de empregos, particularmente na segunda metade da década, quando o câmbio estava valorizado.

$\mathrm{O}$ processo de abertura, ao expor as indústrias a um ambiente mais competitivo, provocou uma reestruturação de processo produtivo. A busca de maior produtividade teve como reflexo direto uma diminuição dos postos de trabalho, embora 
alguns autores indiquem que este movimento foi parcialmente compensado pelo aumento da mão-de-obra ocupada no setor Serviços.

No entanto, a análise dos dados mostrou que o crescimento médio anual da oferta de postos de trabalho foi de aproximadamente $0,71 \%$, tal que, em toda a década de 1990, foram gerados aproximadamente 3,8 milhões de postos de trabalho. Durante o mesmo período, a população economicamente ativa cresceu, em média, 2,3\%. O resultado foi o aumento da taxa de desemprego de 4,65\% em 1990 para 8,26\% em 1999.

A conjugação dos dados das PNADs e das matrizes de insumo-produto, obtidas das Contas Nacionais, possibilitou ainda evidenciar as mudanças setoriais na oferta de postos de trabalho e no perfil dos trabalhadores ocupados ao longo da década de 1990. Além disso, também foi possível identificar a importância dos componentes da demanda total na geração de postos de trabalho nos vários setores da economia.

Quanto ao perfil do trabalhador, a análise dos dados revelou várias mudanças na década de 1990. Do total dos trabalhadores ocupados, houve um pequeno crescimento no emprego da mão-de-obra feminina, a qual vem participando cada vez mais da força de trabalho. Embora a idade do trabalhador ocupado tenha demonstrado que as empresas estão utilizando mão-de-obra mais madura, o trabalhador ocupado na década de 1990 ingressou cedo no primeiro emprego, embora aqueles que estão ingressando no mercado de trabalho atualmente, o estão fazendo com idade mais elevada. Excetuando-se a Administração Pública, observou-se uma diminuição da ocupação de trabalhadores com carteira assinada, ao mesmo tempo em que observou-se uma elevada rotatividade. Em todos os anos da década, a maior proporção da mão-deobra ocupada estava no atual emprego a menos que 2 anos. A escolaridade média da mão-de-obra ocupada cresceu, mas continua baixa quando comparada com outros países.

A utilização das matrizes de insumo-produto permitiu analisar a importância de cada um dos componentes da demanda final na geração de postos de trabalho. Os resultados mostraram que, na década de 1990, o consumo intermediário foi 
responsável, em média, por mais da metade da oferta de postos de trabalho. A demanda final foi significativa em onze setores e apenas em um a exportação teve a maior participação na oferta de postos de trabalho.

A partir destes resultados, podem ser feitas algumas recomendações de política no que se refere ao aumento da oferta de postos de trabalho.

Conforme demonstrado pela análise da importância dos componentes da demanda total no emprego, observou-se que as os postos de trabalho são mais influenciados pela atividade econômica interna que pela demanda externa. Neste sentido, dadas as restrições externas da economia brasileira, políticas públicas de geração de emprego pela substituição de importações teriam um elevado papel, na medida em que, de um lado, contribuiriam para aumentar a oferta de postos de trabalho e, de outro, para aliviar as contas externas do país.

Políticas de incentivo às exportações, por sua vez, também poderiam ser úteis, atingindo um duplo objetivo: geração de emprego e melhoria da balança comercial. Neste caso, o setor Agropecuária parece ser o que melhor responde ao aumento das exportações.

Não obstante, a globalização fez com que as empresas brasileiras fossem levadas a concorrer num mercado cada vez mais competitivo. A reestruturação produtiva decorrente deste processo baseou-se fortemente no aumento da produtividade.

Do ponto de vista da oferta de postos de trabalho, a exigência por trabalhadores mais qualificados parece ter aumentado. Como este movimento parece ser irreversível, resta às políticas públicas oferecer melhores condições de treinamento e qualificação da mão-de-obra e, no caso das gerações futuras de trabalhadores, capacitálos por meio do investimento na educação a desempenhar adequadamente as atividades de produção.

Por outro lado, o aumento do número de postos de trabalho sem carteira assinada, aliado à alta rotatividade parece indicar a necessidade de mudanças na 
legislação trabalhista, buscando dar maior flexibilidade de contração ao empregador, de tal sorte que ele não seja desprovido da totalidade de seus direitos.

Finalmente, cabe lembrar que qualquer política pública deve levar em consideração as especificidades de cada região. Neste sentido, trabalhos futuros podem contribuir para o conhecimento da realidade regional da oferta de postos de trabalho e do perfil da mão-de-obra ocupada, adotando uma abordagem regional do problema aqui estudado. 


\section{REFERÊNCIAS BIBLIOGRÁFICAS}

ALVES, G. O novo (e precário) mundo do trabalho: reestruturação produtiva e crise do sindicalismo. São Paulo: Boitempo Editorial, 2000. 375p.

AMADEO, E.J. Dez pontos sobre a situação recente do mercado de trabalho. Notas sobre o Mercado de Trabalho, n.5, p.1-26, ago. 1998.

AMADEO, E.J. Rumos, desafios e o papel do Ministério do Trabalho. Mercado de Trabalho Brasileiro. Brasília: Câmara dos Deputados, 1998. 29p.

AMADEO, E.J.; ESTEVÃO, M. A teoria econômica do desemprego. São Paulo: Hucitec, 1994. 254p.

ARBACHE, J.; CORSEUIL,C. Liberalização comercial e estruturas de emprego e salário. Rio de Janeiro: IPEA, 2001. 16p. (Texto para discussão, 801)

BALTAR, P.A. Crise contemporânea e mercado de trabalho no Brasil. In: OLIVEIRA, M.A. (Org.). Economia \& Trabalho: textos básicos. Campinas: UNICAMP, IE, 1998. p.129-146.

BARROS, R.; FOGEL, M.; MENDONÇA, R. Perspectivas para o mercado de trabalho brasileiro ao longo da próxima década. Rio de Janeiro: IPEA, 1997. 29p. (Texto para discussão, 526)

BARROS, R.P.; MENDONÇA, R.; FOGUEL, M. O impacto da abertura comercial sobre o mercado de trabalho brasileiro. In: ENCONTRO BRASILEIRO DE ECONOMIA, 24., Águas de Lindóia, 1996. Anais. São Paulo: Parma, 1996. p.534552. 
BARROS, R.P.; RAMOS, L.; FIRPO, S. Geração de empregos e realocação espacial no mercado de trabalho brasileiro. Notas sobre o mercado de trabalho, n.2, p.1-11, jul. 1998.

BARROS, R.P.; FOGEL, M.; MENDONÇA, R. Perspectivas para o mercado de trabalho brasileiro ao longo da próxima década. Rio de Janeiro: IPEA, 1997. 29p. (Texto para discussão, 526)

BONELLI, R.; VEIGA, P.; BRITO, A.F. As políticas industrial e de comércio exterior no Brasil: rumos e identificações. Rio de Janeiro: IPEA, 1997. 77p. (Texto para discussão, 527)

BRASIL. Ministério do Desenvolvimento, Indústria e Comércio Exterior. Ações setoriais para o aumento da competitividade da indústria brasileira. http://www.mdic.gov.br (12 jul. 2001)

BRASIL. Ministério do Trabalho. Emprego no Brasil: diagnóstico e políticas. Brasília: MTb, Assessoria Especial do Ministro, 1998. 84p.

CARDOSO JÚNIOR, J.C. Crise e desregulação do trabalho no Brasil. Rio de Janeiro: IPEA, 2001. 60p. (Texto para discussão, 814)

CARVALHEIRO, N. Criação e destruição de empregos no Brasil no período 1990/1996: A óptica das matrizes de insumo-produto. In: KON, A.; BANKO, C.; MELCHER, D. et al. (Org.). Costos sociales de lãs reformas neoliberais em América Latina. Caracas: EITT /FAPESP/Universidad Central de Venezuela, 2000. 392p.

CELLA, G. The input-output measurement of interindustry linkages. Oxford Bulletin of Economics and Statistics, v.70, p.705-712, 1984.

COMISIÓN ECONÓMICA PARA AMÉRICA LATINA Y EL CARIBE. Panorama social de América Latina 2000-2001. Santiago de Chile: Nações Unidas, 2001. $273 p$.

CHINKOOK, L.; SCHLUTER, G. Effect of trade on the demand for skilled and unskilled workers. Economic Systems Research, v.11, n.1, p.49-65, 1999. 
CLEMENTS, B. On the decomposition and normalization of interindustry linkages. Economic Letters, v.33, p.337-340, 1990.

CUADRADO-ROURA, J.R. El sector servicios y el empleo en España: evolucion reciente y perspectivas de futuro. Bilbao: Fundación BBV, 1999. 671p.

DEDECCA, C.S. Conceitos e estatísticas básicas sobre mercado de trabalho. In: OLIVEIRA, M.A. (Org.). Economia \& Trabalho: textos básicos. Campinas: UNICAMP, IE, 1998. p.95-112.

FERRANTI, D.; THOMAS, V.; ARRIAGADA, A.M. et al. Empregos no Brasil: prioridades de políticas. Brasília: Banco Mundial/IPEA, 2002. 12p.

FERRAZ, G.; ROCHA, F. Os serviços de limpeza e conservação no Brasil. Rio de Janeiro: IPEA, 1998. 21p. (Texto para discussão, 601)

FOGUEL, M. A jornada de trabalho a tempo parcial no Brasil. Notas sobre o mercado de trabalho, n.9, p.1-12, nov. 1998.

FUNDAÇÃO INSTITUTO BRASILEIRO DE GEOGRAFIA E ESTATÍSTICA. Sistema de contas nacionais: tabelas de recursos e usos: metodologia. Rio de Janeiro, 1997. 49p. (Textos para discussão, 88)

GUILHOTO, J.J.M. Um modelo computável de equilíbrio geral para planejamento e análise de políticas agrícolas (PAPA), na economia brasileira. Piracicaba, 1995. 258p. Tese (Livre-Docência) - Escola Superior de Agricultura "Luiz de Queiroz", Universidade de São Paulo.

GUILHOTO, J.J.M.; SONIS, M.; HEWINGS, G. et al. Índices de ligações e setoreschave na economia brasileira: 1959/80. Pesquisa e Planejamento Econômico, v.24, p.287-314, 1994.

GUILHOTO, J.J.M.; SONIS, M.; HEWINGS, G. Linkages and multipliers in a multiregional famework: integration of alternative approaches. Urbana: Regional Economics Applications Laboratory, 1996. 20p. (Discussion Paper, 96-T-8) 
GUILHOTO, J.J.M.; SESSO, U.; LOPES, R.L. et al. Nota metodológica: construção da matriz insumo-produto utilizando dados preliminares das contas nacionais (compact disc). In: ENCONTRO DE ESTUDOS REGIONAIS E URBANOS, 2., São Paulo, 2002. Anais. São Paulo: ABER, 2002. 19p.

GUIMARÃES, L.N. As economias regionais e o mercado de trabalho no Brasil dos anos de 1990. In: KON, A. (Org.). Unidade e fragmentação: a questão regional no Brasil. São Paulo: Perspectiva, 2002. cap.6, p.165-196.

INSTITUTO DE PESQUISA ECONÔMICA APLICADA. IPEADATA. http://www.ipeadata.gov.br (02 jul. 2002)

KON, A. Desenvolvimento regional e trabalho no Brasil. São Paulo: Associação Brasileira de Estudos do Trabalho, 1998. 140p. (Coleção ABET - Mercado de trabalho, 2)

LACERDA, A.C.; BOCCHI, J.I.; REGO, J.M. et al. Economia brasileira. São Paulo: Saraiva, 2000. 262p.

LEONTIEF, W. A economia do insumo-produto. São Paulo: Nova Cultural, 1986. 226p. (Coleção Os economistas)

LEONTIEF, W. Input-output economics. 2.ed. New York: Oxford University Press, 1986. 436p.

MARQUES, I.C. O Brasil e a abertura dos mercados: o trabalho em questão. São Paulo: Associação Brasileira de Estudos do Trabalho, 1998. 158p. (Coleção ABET Mercado de trabalho, 10)

MATTOSO, J. A desordem do trabalho. São Paulo: Scritta, 1995. 210p.

MATTOSO, J. O Brasil desempregado: como foram destruídos mais de 3 milhões de empregos nos anos 90. São Paulo: Fundação Perseu Abramo, 1999. 47p.

MATTOSO, J.; BALTAR, P.A. Transformações estruturais e emprego nos anos 90. Cadernos do CESIT, n.21, p.1-21, out. 1996. 
MELO, H.P.; ROCHA, F.; FERRAZ, G. et al. O setor serviços no Brasil: uma visão global: 1985/95. Rio de Janeiro: IPEA, 1998. 43p. (Texto para discussão, 549)

MELO, H.P.; ROCHA, F.; FERRAZ, G. et al. É possível uma política para o setor serviços ? Rio de Janeiro: IPEA, 1997. 19p. (Texto para discussão, 457)

MILLER, R.; BLAIR, P. Input-output analysis: foundations and extensions. Englewood Cliffs: Prentice-Hall, 1985. 464p.

MOREIRA, M.; NAJBERG, S. Abertura comercial: criando ou exportando empregos ? Rio de Janeiro: BNDES, 1997. (Texto para discussão, 59)

NERI, M.; CAMARGO, J.M.; REIS, M.C. Mercado de trabalho nos anos 90: fatos estilizados e interpretações. Rio de Janeiro: IPEA, 2000. 31p. (Texto para discussão, 743)

ORGANIZATION FOR ECONOMIC COOPERATION AND DEVELOPMENT. Employment outlook 2002. http://www.oecd.org/pdf/M00032000/M00032007.pdf (06 jan. 2003)

PINHEIRO, A.; GIAMBIAGI, F. GOSTKORZEWICZ, J. O desempenho macroeconômico do Brasil nos 90. In: GIAMBIAGI, F.; MOREIRA M. (Org.). A economia brasileira nos anos 90. Rio de Janeiro: BNDES, 1999. p.11-41.

POCHMANN, M. O trabalho sob fogo cruzado: exclusão, desemprego e precarização no final do século. São Paulo: Contexto, 1999. 205p.

RAMOS, L.; REIS, J.G.A. Emprego no Brasil nos anos 90. Rio de Janeiro: IPEA, 1997. 28p. (Texto para discussão, 468)

ROCHA, F. Composição do crescimento dos serviços na economia brasileira: uma análise da matriz insumo-produto: 1985/95. Rio de Janeiro: IPEA, 1997. 18p. (Texto para discussão, 522)

ROSANDISKI, E.N.; SILVA, R.A.C. Mudanças no perfil do emprego no Brasil nos anos 90. São Paulo: DIEESE; Campinas: CESIT, 1999. p.143-168: Emprego e desenvolvimento tecnológico: artigos dos pesquisadores. 